\title{
Biomonitoring of Environmental Status and Trends (BEST) Program: Environmental Contaminants and their Effects on Fish in the Yukon River Basin
}

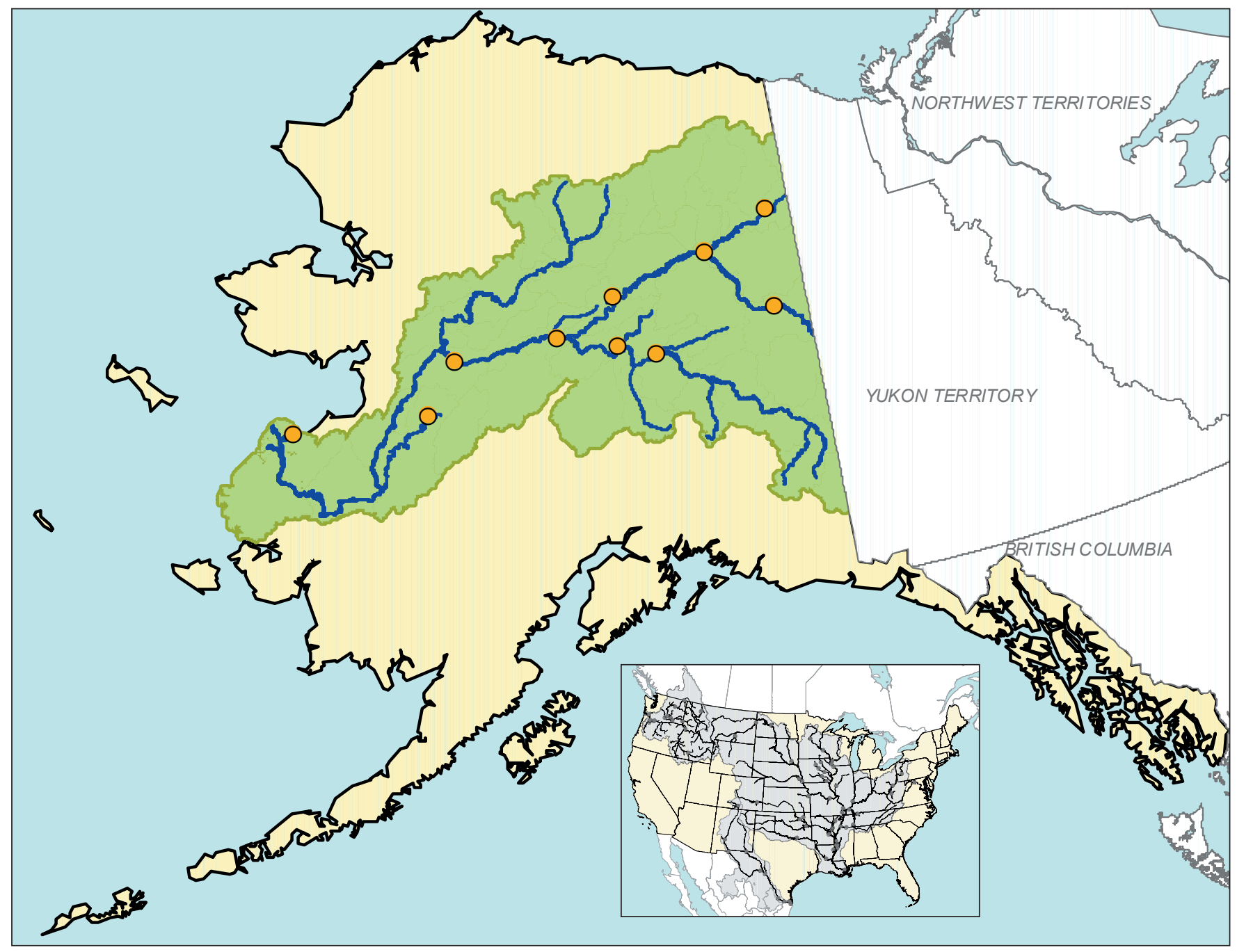

Scientific Investigations Report 2004—5285 
Front cover: The Alaska state map shows the Yukon River Basin (green) and staions sampled in this study (orange). Shown in gray (inset map) are major river basins and stations in the conterminous U.S. sampled during other Biomonitoring of Environmental Status and Trends (BEST) Program investigations. 


\section{Biomonitoring of Environmental Status and Trends (BEST) Program: Environmental Contaminants and their Effects on Fish in the Yukon River Basin}

By Jo Ellen Hinck, Timothy M. Bartish, Vicki S. Blazer, Nancy D. Denslow, Tim S.

Gross, Mark S. Myers, Patrick J. Anderson, Carl E. Orazio, and Donald E. Tillitt

Scientific Investigations Report 2004-5285 


\section{U.S. Department of the Interior \\ Gale A. Norton, Secretary \\ U.S. Geological Survey \\ Charles G. Groat, Director}

\section{U.S. Geological Survey, Reston, Virginia: 2004}

For more information about the USGS and its products:

Telephone: 1-888-ASK-USGS

World Wide Web: http://www.usgs.gov/

Any use of trade, product, or firm names in this publication is for descriptive purposes only and does not imply endorsement by the U.S. Government.

Although this report is in the public domain, permission must be secured from the individual copyright owners to reproduce any copyrighted materials contained within this report. 


\section{Preface}

The study described in this report was conducted as part of the U.S. Geological Survey (USGS) Biomonitoring of Environmental Status and Trends (BEST) Program. BEST evolved from previous Federal monitoring programs including the National Pesticide Monitoring Program (NPMP) of the 1960s, renamed the National Contaminant Biomonitoring Program (NCBP) in the early 1970s, which also screened for elemental contaminants. The U.S. Fish and Wildlife Service (USFWS) participated in the NPMP and maintained the NCBP by monitoring concentrations of persistent contaminants in freshwater fish and avian wildlife through 1986 . The BEST Program was initiated in the 1990s to build on information produced by these earlier programs and to provide more biologically relevant information regarding potential contaminant effects on lands and species under USFWS management. The program was transferred to the National Biological Survey in 1993 and ultimately to USGS in 1996. The Large River Monitoring Network of BEST has principal emphasis to identify, monitor, and assess the effects of chemical contaminants on the fish health in the nation's large rivers. The 2002 Yukon River Basin (YRB) study represented a continuation of studies conducted in the Mississippi River Basin in 1995 and the Columbia River and Rio Grande Basins in 1997.

\section{Acknowledgements}

This study was conducted jointly by the USGS through its research centers in Columbia, Missouri (Columbia Environmental Research Center, CERC), Gainesville, Florida (Florida Integrated Science Center), and Kearneysville, West Virginia (Leetown Science Center, LSC); the Northwest Fisheries Science Center (NWFSC) of the National Oceanic and Atmospheric Administration (NOAA) in Seattle, Washington; and the U.S. Fish and Wildlife Service (USFWS) of Fairbanks, Alaska. The study was facilitated through a Research Work Order with the USGS-Florida Cooperative Fish and Wildlife Research Unit at the University of Florida (UF), Gainesville, Florida. Many individuals representing USGS, USFWS, UF, and other organizations contributed substantially during the conduct of the study. K. Mueller and A. Matz (USFWS) organized and supervised field portions of the study. C. Hemming, C.M.

Hemming, T. Wertz, F. Anderson, C. Anderson, D. Nigro, J. Akaran, M. Annis, D. Nicks, and P. Anderson participated in field collections. R. Carroll, D. Bowers, and B. Bowers provided lodging during collections. E. Greer (CERC) provided fish samples for practice dissections. S. Yess (La Crosse USFWS) provided northern pike for a vitellogenin induction study, and A. Delonay (CERC) and R. Gordon and D. Elowiese of the Genoa National Fish Hatchery aided in the transportation of those northern pike. Chemical analyses were conducted by T. May, K. Echols, K. Feltz, J. Meadows, M. Tanner, G. Tegerdine, J. Arms, W. Brumbaugh, and M. Walther of the CERC Environmental Chemistry and Inorganic Chemistry laboratories. Laboratory analyses for biomarkers were performed by D. Nicks (CERC), D. Bowling (LSC), and K. Kroll (UF). D. Bowling (LSC), T. Lee (NWFSC), K. Spring (LSC), and M. Willis (NWFCS) assisted in the histology slide preparation, and E. Frankenberry (LSC) assisted with the macrophage aggregate evaluation. R. Brown (USFWS), and J. Candrl and A. Donahue (CERC) aged the fish. A. Donahue also produced report graphics. R. Lipkin (CERC) managed the bibliographic database and prepared the report for publication. D. Boyt, J. Fox, and M. Keuss provided quality assurance for tables and figures. Special thanks to C. Schmitt (CERC) who provided technical advice on the writing of the report. K. Mueller (USFWS), L. Verbrugge (state of Alaska), and A. Matz (USFWS) reviewed the report and provided additional information. 


\section{Contents}

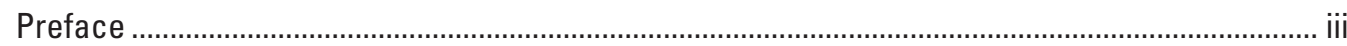

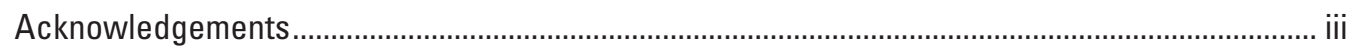

Abstract

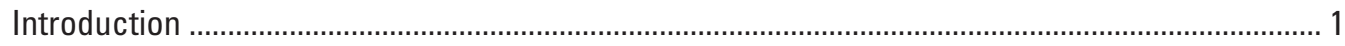

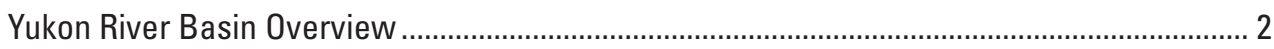

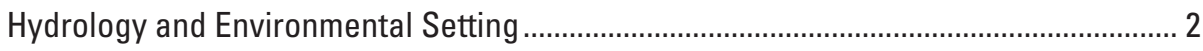

Description of Population ................................................................................... 3

Land Ownership and Economy .............................................................................. 4

Water Quality Impairments and Fish Consumption Advisories................................... 4

Extant Sources of Information on Contaminants in the Yukon River Basin ............................... 5

Major Sources of Contaminants to the Yukon River Basin ................................................... 6

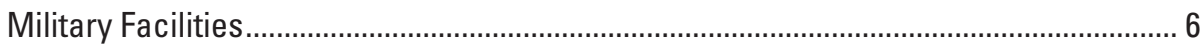

Mining and Extractive Industries ......................................................................... 6

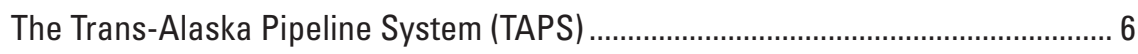

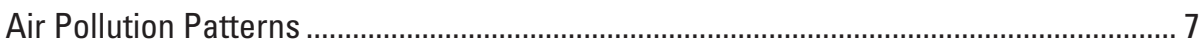

Industrial and Municipal Sources........................................................................... 7

Comprehensive Environmental Response, Compensation, and Liability Act ................... 8

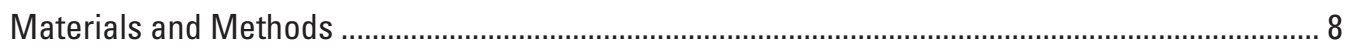

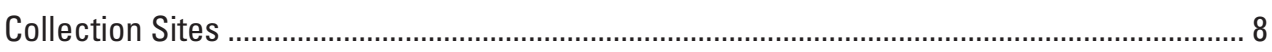

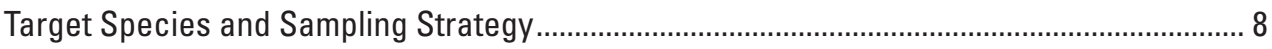

Monitoring Methods Overview........................................................................................... 9

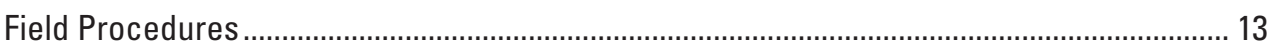

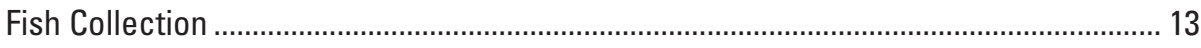

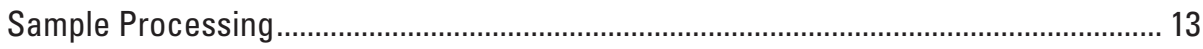

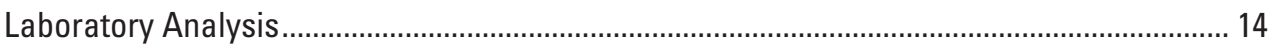

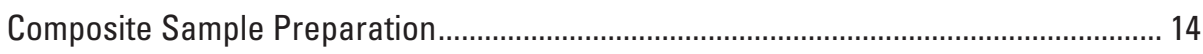

Elemental Contaminants and Moisture Content ............................................................ 14

Organochlorine Contaminants and Lipid Content ...................................................... 15

H4IIE Rat Hepatoma Cell Bioassay .............................................................................. 16

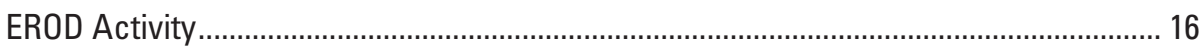

Fish Health Indicators ................................................................................................. 17

General Histopathological Analyses ...................................................................... 17

Quantitative Organism-Level Indicators .................................................................. 17

Macrophage Aggregates ...................................................................................... 17

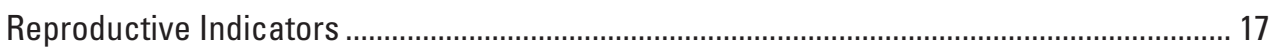

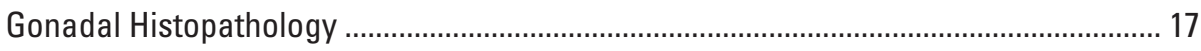

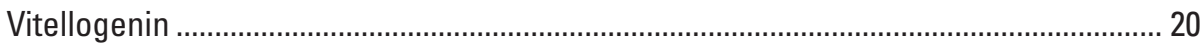

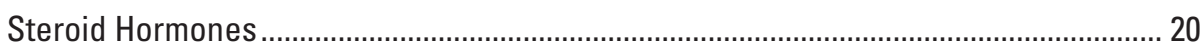

Data Set Composition and Statistical Analyses ……………........................................... 21

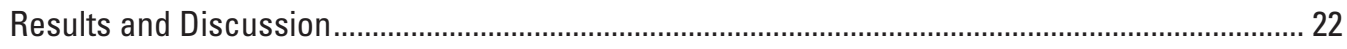

Geographic Distribution and Demographic Characteristics of the Fish Collected................. 22

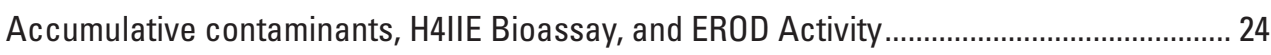

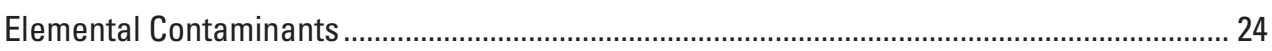

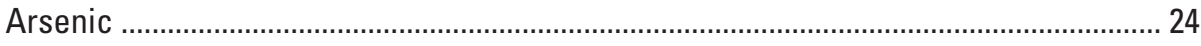

Selenium 


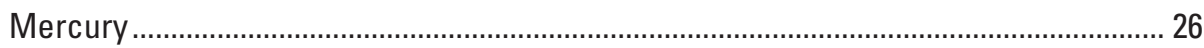

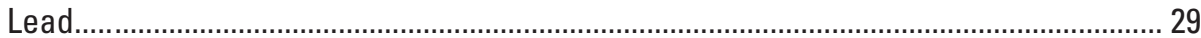

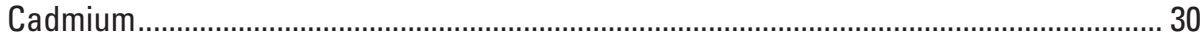

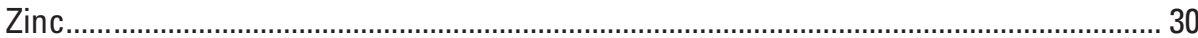

Copper

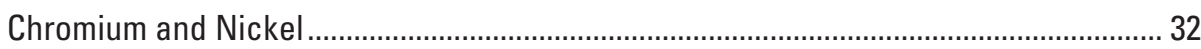

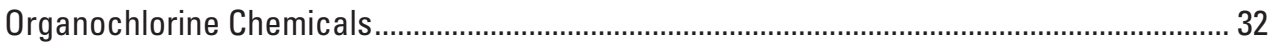

DDT and Its Primary Metabolites ............................................................................... 32

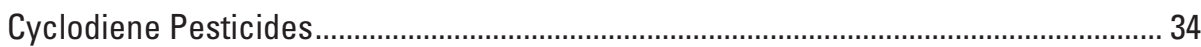

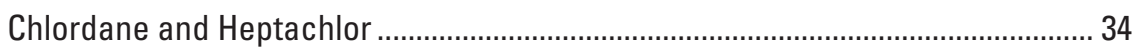

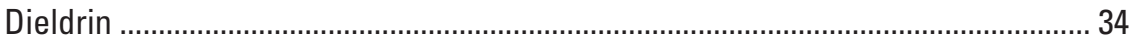

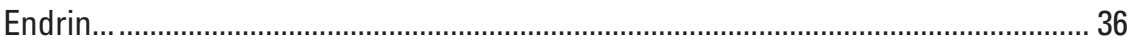

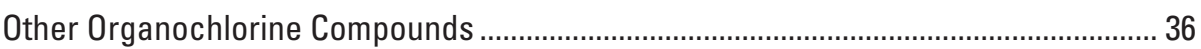

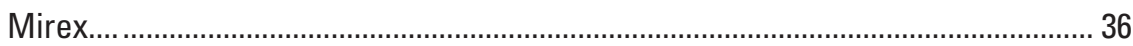

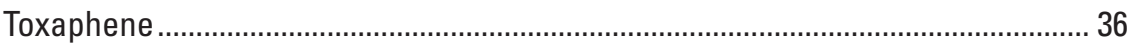

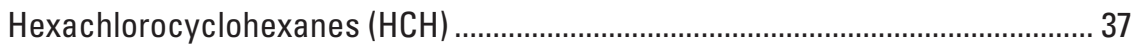

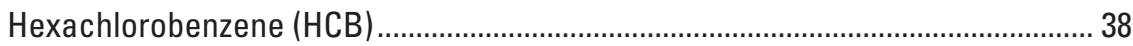

Total PCBs, H4IIE-Derived Dioxin Equivalents, and EROD Activity......................................... 38

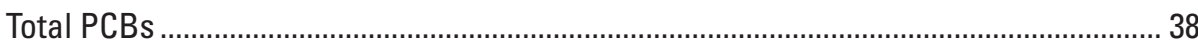

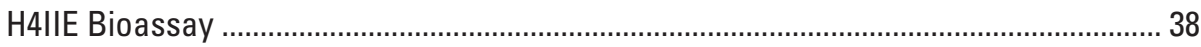

Ethoxyresorufin O-Deethylase (EROD) Activity ............................................................ 39

EROD in Northern Pike ...................................................................................... 39

EROD in Longnose Sucker................................................................................. 39

EROD in Burbot .............................................................................................. 39

Accumulative Contaminants, H4IIE, and EROD: Summary ................................................. 43

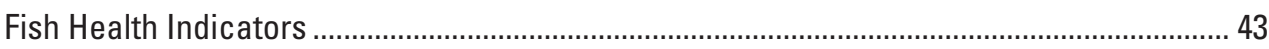

Organism-Level Indicators ...................................................................................... 43

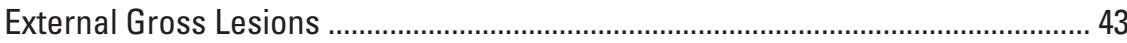

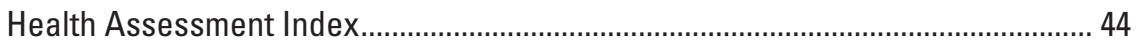

Condition and Organosomatic Indices ..................................................................... 44

Condition and Organosomatic Indices in Northern Pike...................................... 44

Condition and Organosomatic Indices in Longnose Sucker .................................. 45

Cellular and Histopathological Indicators ..................................................................... 48

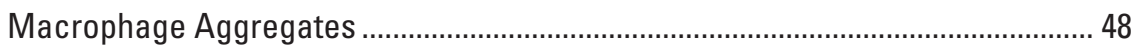

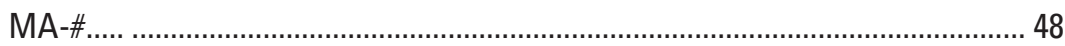

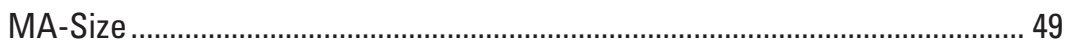

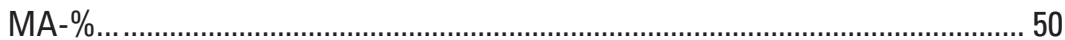

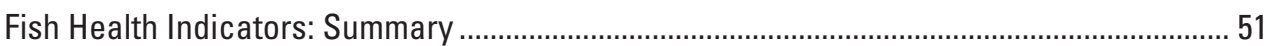

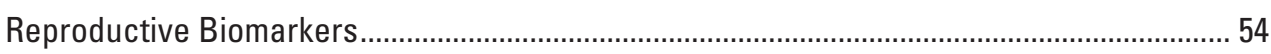

Gonadal Histopatholgy, Vitellogenin, and Steroid Hormones ...................................... 54

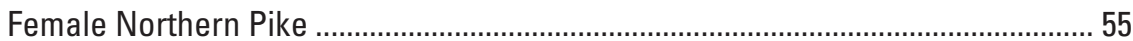

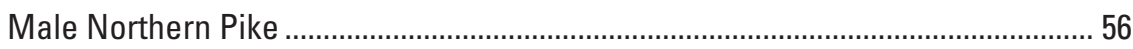

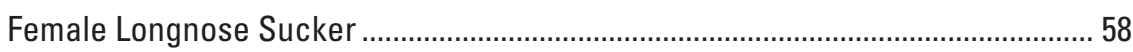

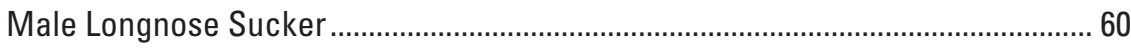

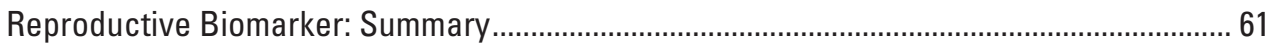

Spatial patterns in contaminant concentrations and biomarker responses .......................... 63

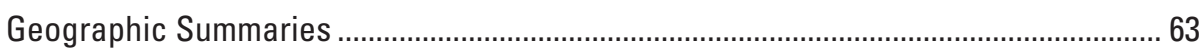

Correlations Between Contaminant Concentrations and Biological Endpoints ............ 67 


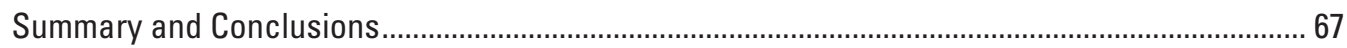

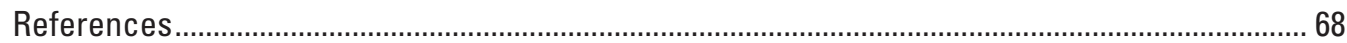

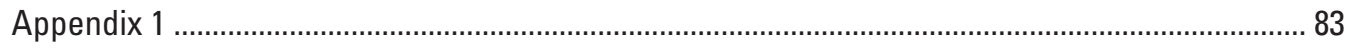

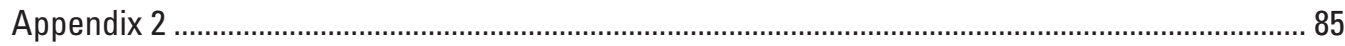

\section{Figures}

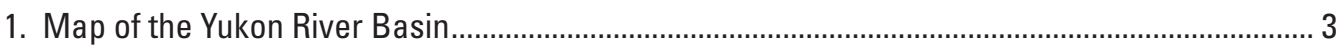

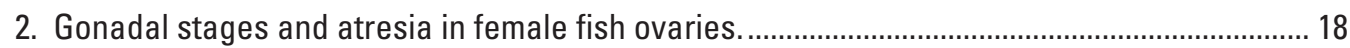

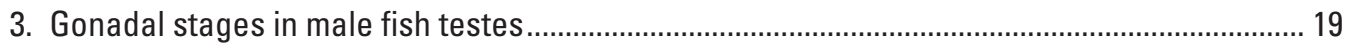

4. Concentrations of arsenic and selenium by station and species in whole body fish composite samples collected in the Yukon River Basin in 2002 ..................................................... 25

5. Concentrations of mercury by station and species in whole body fish composite samples col-

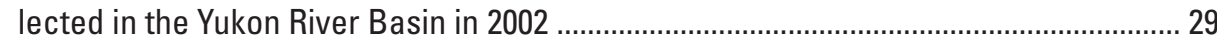

6. Concentrations of cadmium by station and species in whole body fish composite samples collected in the Yukon River Basin in 2002 .................................................................... 30

7. Concentrations of zinc, copper, chromium, and nickel by station and species in whole body fish composite samples collected in the Yukon River Basin in 2002............................... 31

8. Weighted geometric mean concentrations of $p, p^{\prime}-\mathrm{DDT}, \mathrm{DDE}$, and DDD by station in whole body fish composite samples collected in the Yukon River Basin in 2002 ....................... 34

9. Concentrations of $p, p^{\prime}$-DDE, toxaphene, total chlordanes, and dieldrin by station and species in whole body fish composite samples collected in the Yukon River Basin in 2002....... 36

10. Weighted geometric mean concentrations of chlordane-related compounds by station in whole body fish composite samples collected in the Yukon River Basin in 2002 .......... 37

11. Concentrations of total PCBs by station and species in whole body fish composite samples

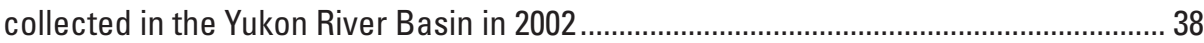

12. Hepatic microsomal EROD activity by station in female and male northern pike and longnose sucker collected in the Yukon River Basin in 2002 .......................................................... 44

13. Fish health indicators by station in female and male northern pike collected in the Yukon

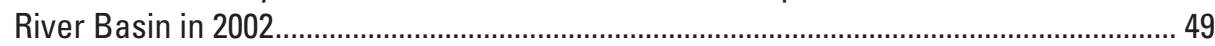

14. Fish health indicators by station in female and male longnose sucker collected in the Yukon

River Basin in 2002................................................................................................. 51

15. Splenic macrophage aggregate parameters by station in northern pike collected in the Yukon River Basin in 2002 ........................................................................................ 53

16. Splenic macrophage aggregate parameters by station in longnose sucker collected in the Yukon River Basin in 2002 ....................................................................................... 53

17. Gonadal stage of female and male northern pike collected in the Yukon River Basin in 2002 56

18. Reproductive health indicators by station in female northern pike collected in the Yukon

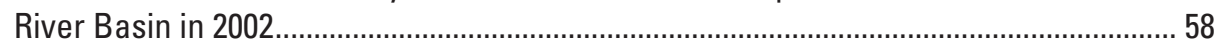

19. Reproductive health indicators by station in male northern pike collected in the Yukon River Basin in 2002

20. Gonadal stage of female and male longnose sucker collected in the Yukon River Basin in 2002

21. Reproductive health indicators by station in female longnose sucker collected in the Yukon River Basin in 2002

22. Reproductive health indicators by station in male longnose sucker collected in the Yukon

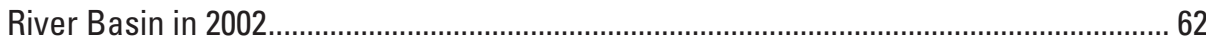

23. Maximum concentrations of mercury and selenium in composite samples of whole fish..... 65 
24. Plasma vitellogenin in male northern pike and longnose sucker. 66

25. Ratio of estradiol to 11-ketotestosterone in northern pike and longnose sucker. 67

\section{Tables}

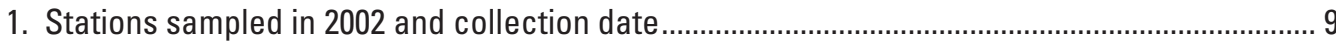

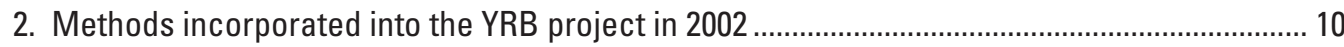

3. Organochlorine chemical and elemental contaminants measured in whole body fish compos-

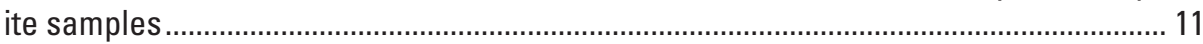

4. Monitoring and assessment strategy for polycyclic aromatic and polyhalogenated hydrocarbons ............................................................................................................... 13

5. Number of fish collected, organized by species, station, and gender in the Yukon

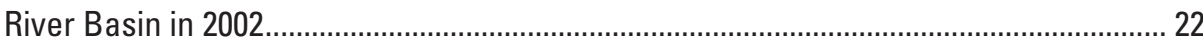

6. Lengths, weights, and ages of northern pike collected in the Yukon River Basin in 2002......... 23

7. Lengths, weights, and ages of longnose sucker and burbot collected in the Yukon River Basin in 2002 24

8. Percent of samples and stations that exceeded limit of detection concentrations for elemental contaminants in composite samples of whole fish from the Yukon River Basin in 2002 26

9. Unweighted geometric mean, minimum, and maximum concentrations of elemental contaminants in fish collected in the Yukon River Basin in 2002

10. Spatial trends of chemical contaminants in fish collected in the Yukon River Basin in 2002

11. Percent of samples and stations with concentrations exceeding the limit of detection for organochlorine chemical residues in composite samples of whole fish in the Yukon River Basin in 2002

12. Unweighted geometric mean, minimum, and maximum concentrations of organochlorine chemical contaminants in fish from stations in the Yukon River Basin in 2002

13. Results of preliminary analysis of variance investigating the effects of various factors on biomarker responses in northern pike and longnose sucker in the Yukon River Basin in 2002

14. Geometric mean and range of microsomal EROD activities (pmol/min/mg protein) in fish collected in the Yukon River Basin in 2002

15. Number and location of external lesions identified on fish collected in the Yukon River Basin in 2002

16. Distribution of Health Assessment Index (HAI) scores among northern pike, longnose sucker, and burbot collected in the Yukon River Basin in 2002.

17. Arithmetic mean of condition factor and hepatosomatic index by species and station in northern pike, longnose sucker, and burbot collected in the Yukon River Basin in 2002

18. Arithmetic mean of splenosomatic index by species, gender, and station in northern pike, longnose sucker, and burbot collected in the Yukon River Basin in 2002

19. Arithmetic mean of macrophage aggregate density, macrophage aggregate area, and percent tissue occupied by macrophage aggregate by species, gender and station in northern pike, longnose sucker, and burbot collected in the Yukon River Basin in 2002

20. Arithmetic mean of gonadosomatic index, vitellogenin, and atresia by gender, species, and station in northern pike, longnose sucker, and burbot collected in the Yukon River Basin in 2002 
21. Arithmetic mean of estradiol, eleven-ketotestosterone, and ratio of E/KT by gender, species, and station in northern pike, longnose sucker, and burbot collected in the Yukon River

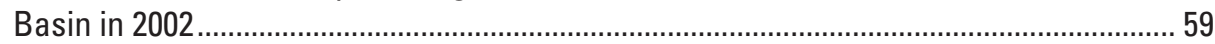

22. Summary of chemical and biological indicator results by Yukon River Basin station .............. 64

23. Significant Spearman rank correlations between biomarkers and contaminants................... 68

Appendix 1. Nominal Method Detection Limits and results of quality assurance for organochlorine chemicals analyzed in whole body fish composites collected in the Yukon River Basin in 2002

Appendix 2. Histological observations in northern pike, longnose sucker, and burbot collected in the Yukon River Basin in 2002

\section{Conversion Factors}

\begin{tabular}{lcl}
\hline Multiply & By & To obtain \\
\hline & Length & \\
centimeter $(\mathrm{cm})$ & 0.3937 & inch (in) \\
millimeter $(\mathrm{mm})$ & 0.03937 & inch $(\mathrm{in})$ \\
meter $(\mathrm{m})$ & 3.281 & foot $(\mathrm{ft})$ \\
kilometer $(\mathrm{km})$ & 0.6214 & mile $(\mathrm{mi})$ \\
\hline & Area & \\
\hline square kilometer $\left(\mathrm{km}^{2}\right)$ & 0.3861 & square mile $(\mathrm{mi})$ \\
cubic kilometer $\left(\mathrm{km}^{3}\right)$ & 0.2399 & cubic mile $\left(\mathrm{mi}^{3}\right)$ \\
\hline & Volume & \\
\hline milliliter $(\mathrm{mL})$ & 0.03381 & fluid ounce $(\mathrm{fll}$ oz) \\
liter $(\mathrm{L})$ & 1.057 & quart $(\mathrm{qt})$ \\
liter $(\mathrm{L})$ & 0.2642 & gallon $($ gal) \\
cubic meter $\left(\mathrm{cm}{ }^{3}\right)$ & 0.0002642 & million gallons $(\mathrm{Mgal})$ \\
\hline & Mass & \\
\hline kilogram $(\mathrm{kg})$ & 2.205 & pound, avoirdupois $(\mathrm{lb})$ \\
\hline & Concentration & \\
\hline microgram per gram $(\mu \mathrm{g} / \mathrm{g})$ & $=$ & part per million $\left(\mathrm{ppm} ; 10^{6}\right)$ \\
nanogram per gram $(\mathrm{ng} / \mathrm{g})$ & $=$ & part per billion $\left(\mathrm{ppb} ; 10^{9}\right)$ \\
picogram per gram $(\mathrm{pg} / \mathrm{g})$ & $=$ & part per trillion $\left(\mathrm{pptr} ; 10^{12}\right)$ \\
milligram per millimeter $(\mathrm{mg} / \mathrm{mL})$ & $=$ & part per thousand $\left(\mathrm{ppt} ; 10^{3}\right)$ \\
milligram per liter $(\mathrm{mg} / \mathrm{L})$ & $=$ & part per million $\left(\mathrm{ppm} ; 10^{6}\right)$ \\
microgram per liter $(\mu \mathrm{g} / \mathrm{L})$ & $=$ & part per billion $\left(\mathrm{ppb} ; 10^{9}\right)$ \\
\hline
\end{tabular}

Temperature in degrees Celsius $\left({ }^{\circ} \mathrm{C}\right)$ may be converted to degrees Fahrenheit $\left({ }^{\circ} \mathrm{F}\right)$ as follows:

$$
{ }^{\circ} \mathrm{F}=\left(1.8 \times{ }^{\circ} \mathrm{C}\right)+32
$$

Temperature in degrees Fahrenheit $\left({ }^{\circ} \mathrm{F}\right)$ may be converted to degrees Celsius $\left({ }^{\circ} \mathrm{C}\right)$ as follows:

$$
{ }^{\circ} \mathrm{C}=\left({ }^{\circ} \mathrm{F}-32\right) / 1.8
$$


Environmental Contaminants and their Effects on Fish 


\title{
Biomonitoring of Environmental Status and Trends (BEST) Program: Environmental Contaminants and their Effects on Fish in the Yukon River Basin
}

\author{
Jo Ellen Hinck', Timothy M. Bartish², Vicki S. Blazer ${ }^{3}$, Nancy D. Denslow, Tim S. Gross ${ }^{5}$, Mark S. Myers ${ }^{6}$, \\ Patrick J. Anderson ${ }^{7}$, Carl E. Orazio ${ }^{1}$, and Donald E. Tillitt ${ }^{1}$
}

\begin{abstract}
This project collected, examined, and analyzed 217 fish representing three species at 10 stations in the U.S. portion of the Yukon River Basin (YRB) from May to October 2002. Four sampling sites were located on the Yukon River; two were located on the Porcupine River, and one site was on each of the Ray, Tanana, Tolavana, and Innoko Rivers. Northern pike (Esox lucius), longnose sucker (Catostomus catostomus), and burbot (Lota lota) were weighed, measured, and examined in the field for external and internal lesions, and liver, spleen, and gonads were weighed to compute somatic indices. Selected tissues and fluids were collected and preserved for analysis of fish health and biomarker analyses. Composite samples of whole fish from each station were grouped by species and gender and analyzed for organochlorines and elemental contaminants and for dioxin-like activity using the H4IIE rat hepatoma cell bioassay.

Mercury and selenium were the only contaminants measured that exceeded wildlife guidelines or thresholds, and both had been identified as contaminants of concern in previous studies in the YRB. Concentrations of mercury
\end{abstract}

${ }^{1}$ U.S. Geological Survey, Columbia Environmental Research Center (CERC), 4200 New Haven Rd., Columbia, MO 65201.

${ }^{2}$ U.S. Geological Survey, BEST Program, 2150 Centre Ave., Building C, Fort Collins, CO 80526.

${ }^{3}$ U.S. Geological Survey, Leetown Science Center (LSC), 1700 Leetown Rd., Kearneysville, WV 24530.

${ }^{4}$ Center for Environmental and Human Toxicology, PO Box 110885, University of Florida, Gainesville, FL 32611.

${ }^{5}$ U.S. Geological Survey, Florida Integrated Science Center (FISC), 7920 NW $71^{\text {st }}$ St., Gainesville, FL 32653.

${ }^{6}$ National Oceanic and Atmospheric Administration, Northwest Fisheries Science Center, 2725 Montlake Blvd., E, Seattle, WA 98112.

${ }^{7}$ Johnson Controls, c/o USGS, 2150 Centre Ave., Building C, Fort Collins, CO 80526. exceeded $0.1 \mu \mathrm{g} / \mathrm{g}$ ww in at least one species from every YRB station. One or more northern pike and burbot samples from stations on the Tanana River downstream of Fairbanks and on the Yukon River near Galena and The Bridge had concentrations of $\mathrm{Hg}>0.3 \mu \mathrm{g} / \mathrm{g}$ ww. Concentrations of selenium ( $>0.6$ $\mu \mathrm{g} / \mathrm{g}$ ww) also exceeded wildlife criteria in fish samples collected near Fairbanks, The Bridge, near the Charley-Kandik confluence, and Fish Hook Bend. The natural weathering of rocks is believed to be the primary source of selenium to the YRB. Other studies have indicated that atmospheric deposition is currently the major contributor of mercury in the YRB although mining inputs have been reported historically. Fish accumulation of mercury remains a concern for indigenous people and commercial fisheries in the YRB.

Fish health and reproductive biomarkers did not indicate widespread responses to contaminants, but individual fish from sites throughout the basin expressed isolated responses. Concentrations of vitellogenin $>0.01 \mathrm{mg} / \mathrm{mL}$ in male fish may indicate exposure to estrogenic compounds. Multiple male fish collected from near the Charley-Kandik confluence, Fairbanks, Galena, and Innoko had concentrations of vitellogenin $>0.01 \mathrm{mg} / \mathrm{mL}$. Steroid hormone concentrations (estradiol in female fish and 11-ketotestosterone in male fish) were low in northern pike and longnose sucker or both from most YRB stations. Other reproductive biomarkers and fish health indicators were normal in YRB fish. The health of fish was generally good and the concentrations of most chemical contaminants was low in the YRB.

\section{Introduction}

The Yukon River and its major tributaries are considered the transportation corridor of the sparsely populated, roadless interior of Alaska. The river provides fish for subsistence living and drinking water for many rural villages. Other activi- 
ties in the basin include commercial fishing, mining, logging, tourism, and military uses (Brabets and others, 2000). Water quality data are limited for the Yukon River Basin (YRB) although reports indicate that variation in basin water chemistry is due to natural rather than anthropogenic activities (Brabets and others, 2000).

The Yukon River and several of its largest tributaries were studied during the summer of 2002 as part of the Biomonitoring of Environmental Status and Trends (BEST) Program's Large River Monitoring Network (LRMN). The BEST Program is unique among national monitoring programs with its emphasis on characterizing the effects of environmental contaminants on the health of the biota and their supporting habitat. BEST accomplishes this by measuring chemical concentrations and by evaluating the physiological, morphologi$\mathrm{cal}$, and histopathological responses of contaminant exposure by the organism. The primary objective of this study was to document the occurrence and distribution of contaminants and their effects on fish in the YRB and to evaluate the potential risk represented by these contaminants to other biota. Secondary objectives were to compare biomonitoring results from the YRB to other major river systems in North America and to further define benchmarks for the quantification of longterm trends and interpretation of biomarker results. These latter objectives were achieved by building on the results of similar investigations conducted in the Mississippi River Basin (MRB) in 1995 (Schmitt, 2002a), the Rio Grande Basin (RGB) in 1997 (Schmitt and others, 2004), and the Columbia River Basin (CRB) in 1997 (Hinck and others, 2004). The 2002 YRB project was also designed to evaluate the compatibility of the BEST LRMN with the USGS National Stream Quantity Accounting Network (NASQAN) program, which monitors concentrations of dissolved pesticides and other constituents in the waters of the largest U.S. rivers (USGS, 2001).

Findings of the 2002 YRB study are reported in this document. Data from this study have been incorporated into an interactive national database at: www.cerc.usgs.gov/data/best/ search/index.htm. Results from this study, together with those from similar investigations conducted in other river basins, will help resource managers and scientists assess contaminant impacts on fish and on wildlife and human consumers of those fish and to identify areas that warrant further investigation of contaminant threats.

\section{Yukon River Basin Overview}

\section{Hydrology and Environmental Setting}

The YRB is the fourth largest basin in North America; it drains 854,696 square kilometers $\left(\mathrm{km}^{2}\right)$ and is fifth largest in terms of average discharge (Schumm and Winkley, 1994). As a result, the Yukon River is a major contributor of water and solutes to the Arctic Ocean and Bering Sea ecosystems
(Aagaard and Carmack, 1989). The Yukon River originates from the Llewellyn Glacier near Atlin Lake in northwestern British Columbia (Brabets and others, 2000), flows more than $3,219 \mathrm{~km}$ through the Yukon Territory of Canada and central Alaska, and empties into the Bering Sea. The basin receives most of its inflow from runoff from rainfall, snowmelt, and glacial melt with a mean annual discharge near its mouth of 200,000 cubic feet per second (cfs) (Brabets and others, 2000). Most runoff occurs from May to September although timing varies throughout the basin depending on geological and geographical characteristics.

Major tributaries of the Yukon River include the Pelly, Stewart, White, Porcupine, Tolovana, Tanana, Tozitna, Nowitna, Koyukuk, and Innoko Rivers (Fig. 1; Brabets and others, 2000). The Porcupine River, the largest tributary, drains $116,449 \mathrm{~km}^{2}$ in the northeastern part of the YRB and has a mean annual discharge of 22,000 cfs. The Tanana River, the second largest tributary, drains the north side of the Alaska Range $\left(114,736 \mathrm{~km}^{2}\right)$ and has the greatest mean annual discharge $(44,600 \mathrm{cfs})$ of all tributaries in the YRB. The Koyukuk River drains part of the Brooks Range $\left(90,650 \mathrm{~km}^{2}\right)$ and has the greatest mean annual discharge $(27,200 \mathrm{cfs})$ in the western YRB. The Pelly, Stewart, and White Rivers drain the eastern portion of the basin in Canada.

Five general physiographic regions have been recognized in the YRB (Bostock, 1970; Wahrhaftig, 1965). Rolling topography and gentle slopes (37\%) and low mountains (24\%) are the largest regions followed by plains and lowlands (20\%), moderately high rugged mountains (17\%), and extremely high rugged mountains (2\%). The ecology of the YRB is diverse with mountains, rolling plateaus, bottomlands, wetlands, and coastal plains and the basin has been divided into 20 ecological provinces (Gallant and others, 1995). The dominant ecoregions in the basin are Interior Forested Lowlands and Uplands $(21.2 \%)$ and Interior Highlands (16.9\%). Interior Forested Lowlands and Uplands have short warm summers and long cold winters and include lowlands and plateaus along the Yukon River that are underlain with permafrost. The Interior Highlands are found in much of the Tanana River Basin and have rounded low mountains and receive more precipitation than the surrounding lower altitude areas. Talbot and Markon (1986) classified 90\% of the land cover in the YRB as needleleaf forest, tall and low shrublands, broadleaf forest, lichens, barren, and wet herbaceous with the majority $(53.5 \%)$ identified as needleleaf forest dominated by white spruce in welldrained areas and black spruce in lowland areas. Permafrost is present in much of the YRB and acts as a barrier to infiltration that increases the likelihood of flash flooding in streams draining permafrost areas (Brabets and other, 2000). However, the melting and diminishing of permafrost has become a concern to many residents in the YRB.

The YRB has variable climate due to its large size and range of altitude of land surface (Brabets and others, 2000). All of the YRB except for the Yukon Delta is located in the continental zone that has great temperature extremes, and air temperature averages $-5.6^{\circ} \mathrm{C}$. The Yukon Delta is in the transi- 


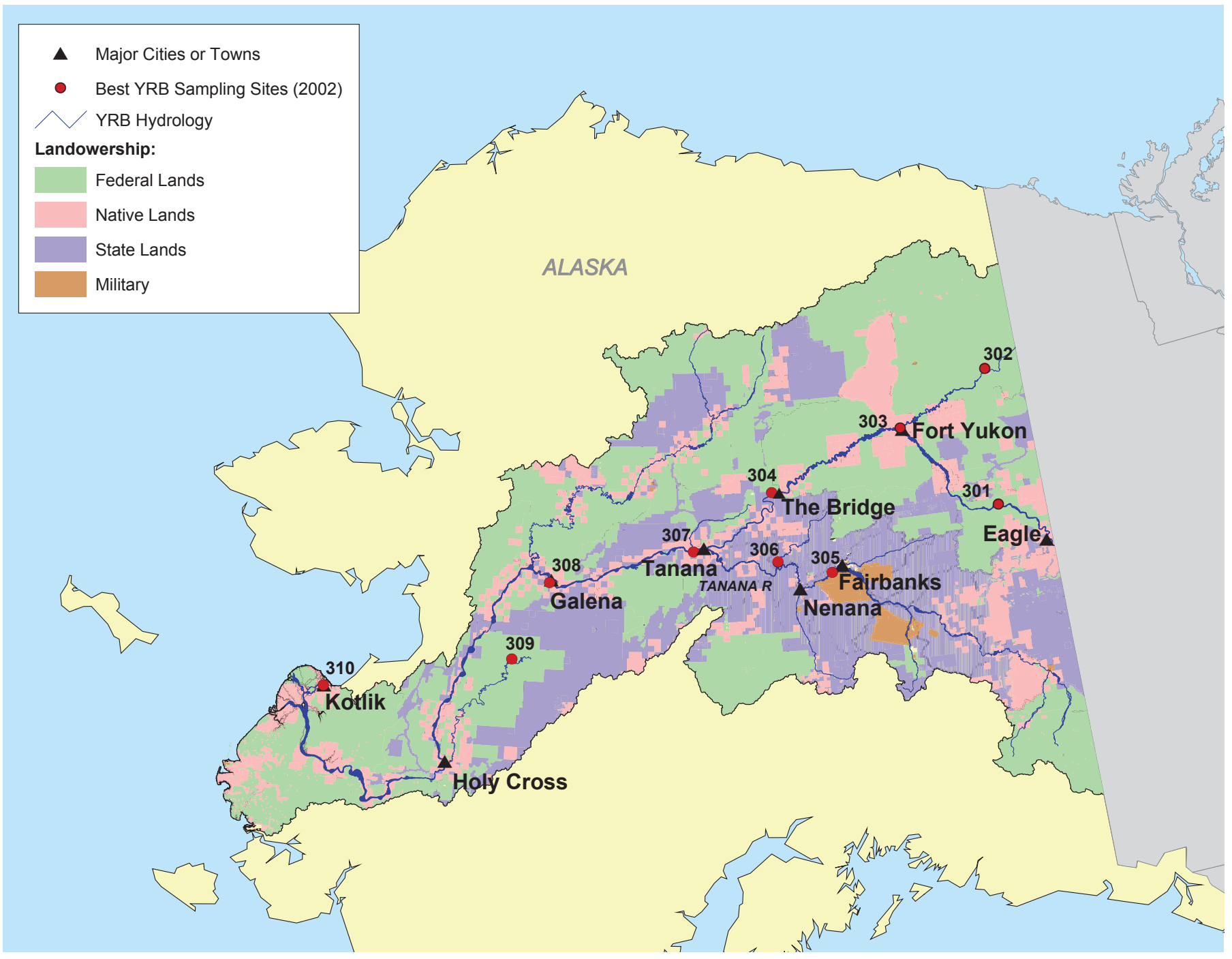

Figure 1. Map of the Yukon River Basin including international boundary, towns and villages, major tributaries, land ownership, and sites sampled in 2002. See Table 1 for station descriptions.

tion zone, which has an average air temperature of $-2.8^{\circ} \mathrm{C}$. Precipitation ranges from 25 to 330 centimeters $(\mathrm{cm})$ annually and approximately half of the precipitation falls as snow from November to March. High mountains may have snowfall year-round, where much of it is stored for long periods in glaciers and icefields. Historical climate records indicate a warming trend in interior Alaska near Fairbanks (Brabets and others, 2000).

\section{Description of Population}

The human population of the YRB is approximately 126,000. Ten percent of these people maintain a subsistence lifestyle, and depend on the basin's fish and game resources (Brabets and others, 2000). Whitehorse is the population center $(23,000$ residents in 1998) in the Canadian portion of the YRB (Environment Canada, 1999). Dawson (2,000 residents) and Faro (1,000 residents) are the next largest Canadian towns, and the remaining villages have populations ranging from 100 to 500 residents. The greater Fairbanks area (Fairbanks and North Star Borough) is the center of the Alaskan population with 84,000 residents in 1996 (Alaska Department of Labor, 1999). Approximately 12,000 other residents are located in 43 YRB villages from the Canadian border to the mouth of the Yukon River. Village populations range from approximately 30 to 800 people with typical villages having fewer than 300 residents, and villages in the Yukon-Koyukuk Delta are larger than interior villages (K. Mueller, personal communication). Accessibility to many villages is restricted to water and air transportation, which isolates the villages from surrounding areas (Alaska Department of Community and Economic Development (ADCED), 2004a).

Many villages in the Yukon-Koyukuk area have high proportions of Athabascan or Yup'ik natives in the population 
who maintain a traditional lifestyle and diet (ADCED, 2004a). Subsistence living represents not only a food source but also a cultural tradition for many native populations, and villages are more dependent on subsistence living when roads are not available to transport fresh fruits and vegetables (ADCED, 2004b; Egeland and others, 1998). The annual harvest of wild foods including fish, mammals, birds, shellfish, and plants has been estimated to range from 170 to $206 \mathrm{~kg} /$ person in rural areas of Alaska (ADCED, 2004b; Wolfe, 2000). The ADCED reported $65 \%$ of the subsistence diet is composed of fish, mostly salmon (Onchorhynchus spp.), in the Yukon-Koyukuk area (ADCED, 2004b). Therefore, the potential risk from contaminants in traditional diets is a concern in the region (Ballew and others, 2004; Egeland and others, 1998).

\section{Land Ownership and Economy}

The YRB in Canada includes parts of two Canadian National Parks and several Habitat Protection Areas (Brabets and others, 2000) and 9\% of the land area of the Canadian Yukon. The U.S. government owns $68 \%$ of the YRB in Alaska (Fig. 1). Four national parks cover $10 \%$ of the area, eight National Wildlife Refuges (NWRs) cover 32\%, and lands managed by the U.S. Bureau of Land Management (USBLM) cover $22 \%$. The U.S. military and native corporations each own $1 \%$ of the land.

Many villages in the YRB rely on Federal and state governments for employment opportunities (ADCED, 2004a; $2004 b$ ). The ADCED (2004b) reported $24.2 \%$ of the population in the Yukon-Koyukuk area was below the poverty level in 2000, and unemployment rates were higher than statewide averages. These percentages are likely a reflection of the time and effort directed toward subsistence living and limited opportunities to earn money (ADCED, 2004b). It has been estimated that the replacement cost of wild harvest foods would be \$3-5 per pound (\$131-219 million annually), indicating the importance of subsistence living in the rural economy (Wolfe, 2000).

Commercial fishing, fish processing, timber processing, oil and gas exploration, fur trapping, and mining are important economic activities in the YRB (ADCED, 2004b; Brabets and others, 2000). Commercial export fishery development has enabled subsistence-based villages to obtain a cash-oriented economy. Salmon including chinook (Onchorhynchus tshawytscha), chum (Onchorhynchus keta), and coho (Onchorhynchus kisutch) are the primary targets of commercial fishing in the YRB, and stocks have remained healthy because their spawning, rearing, and migration habitat remain largely undisturbed. However, declines in salmon populations are being reported (ADCED, 2004b; Brabets and others, 2000). Gross earnings from commercial fishing have dropped $78 \%$ (from approximately $\$ 1,250,000$ to $<\$ 100,000$ ) from 1995 to 2000 in the Yukon-Koyukuk area due to poor salmon runs (ADCED, 2004b).
Mining in the YRB has historically occurred in localized, discrete, headwater streams. Three gold mines are in operation in the YRB and include Illinois Creek mine near Galena, Fort Knox and associate mines near Fairbanks, and Pogo mine near Delta. Logging could add to the YRB economy as large tracts of Federal land are transferred into native corporations and state ownership and as local and export timber demands increase (Brabets and others, 2000). Currently, the Tanana River Basin is the primary logging area in the U.S. portion of the YRB.

\section{Water Quality Impairments and Fish Consumption Advisories}

Waters (rivers, streams, lakes) that do not meet defined water quality standards are listed as impaired. Section 303(d) of the Clean Water Act requires each state to assess all surface waters and list those that are impaired. There are relatively few water bodies throughout the YRB on Alaska's 2002/2003 303(d) list (Alaska Department of Environmental Conservation (ADEC), 2003a). Most impaired rivers and streams are located in small drainages and are listed for turbidity, toxic metals, and petroleum products. Most impaired waters in the YRB are within or near the town of Fairbanks. These waters include the Chena River, Chena Slough, Garrison Slough, Goldstream Creek, and Noyes Slough. Two impairments are located within Denali National Park, and one impairment is located in Wrangell-St. Elias National Preserve within the upper Tanana River drainage.

Fifteen miles of the Chena River have been designated as $100 \%$ impaired from petroleum hydrocarbons, oil, and grease in the sediment attributed to urban runoff from Fairbanks (ADEC, 2003a). These pollutants are also associated with the Chena Slough (for 13 miles) and the Noyes Slough (for 7 miles) impairments. Mining activities are responsible for turbidity impairments within Denali National Park, Goldstream Creek, Birch Creek, and Crooked Creek drainages and metal impairments [manganese (Mn), arsenic (As), iron (Fe), copper $(\mathrm{Cu})$, and cadmium $(\mathrm{Cd})]$ on Cabin Creek within WrangellSt. Elias National Preserve (ADEC, 2003a). The impairment of Garrison Slough has been attributed to polychlorinated biphenyls (PCB) waste (contaminated sediments and waste disposal) from Eielson Air Force Base and although remediation activities have occurred, this waterway remains on the list until remedial actions result in attaining water quality standards (ADEC, 2003a).

The U.S. Environmental Protection Agency's (USEPA) National Listing of Fish and Wildlife Advisories (NLFWA) database was queried for any advisories for any pollutants within Alaska (USEPA, 2003a). Restrictions have not been placed for consuming fish from any waterbody within the state by the USEPA or the state of Alaska. The state of Alaska evaluated fish contaminant data from Alaska and the human health implications of fish consumption and recommended the unrestricted consumption of fish from Alaskan waters (Alaska 
Department of Health and Social Services (ADHSS), 2001; Egeland and others, 1998).

\section{Extant Sources of Information on Contaminants in the Yukon River Basin}

Water quality in the YRB has not been as extensively studied as other large U.S. river basins. The Yukon River drains an extensive landscape, and most water quality studies have focused on particular areas or regions within the basin. In addition, the YRB has considerably fewer anthropogenic impacts and has generally been considered pristine compared to other large U.S. river basins. However, rising concerns over atmospheric mercury $(\mathrm{Hg})$ deposition and metal contamination from mining have led to contaminant studies within the YRB. Information for local contaminant sources such as permitted discharges, fish consumption advisories, and hazardous waste sites has been made available through USEPA databases including the Toxic Release Inventory (TRI), Permit Compliance System (PCS), and the Comprehensive Environmental Response, Compensation, and Liability Information System (CERCLIS). These databases provided information for U.S. facilities and sites only.

Comparatively few national or regional investigations have focused on the YRB. The National Contaminant Biomonitoring Program (NCBP) collected fish from one YRB site (Station 305) from 1969 to 1986 and analyzed organochlorine and elemental contaminants (Schmitt and others, 1999b). The NASQAN program recently completed an environmental and hydrologic overview of the YRB that includes information on water quality issues, specifically carbon cycling and Hg (Brabets and others, 2000). The Canadian government performed a national contaminant study from 1997 to 2003 as part of its Northern Contaminants Program (NCP). Summaries of contaminant impacts pertaining to the physical environment, human health issues, and biological impacts have recently been published (NCP, 2003). Data were available for the headwaters of the Yukon River within the Yukon Territory. The NCP reported that predatory freshwater fish, specifically burbot (Lota lota), contained high concentrations of $\mathrm{Hg}$, and concentrations were increasing in some lakes, especially Lake Laberge. Concentrations of organic contaminants were much lower than Hg. However, concentrations of toxaphene in burbot livers exceeded consumption guidelines in fish collected from Lake Laberge, although concentrations have been decreasing since the mid-1990s.

There are eight NWRs managed by U.S. Fish and Wildlife Service (USFWS) located within the YRB. These include the Arctic, Yukon Flats, Kanuti, Nowitna, and Tetlin NWRs in eastern Alaska and Koyukuk, Innoko, and Yukon Delta NWRs in western Alaska. The USFWS has studied contaminant issues in multiple YRB NWRs since the late 1980s, and data are available for water, sediment, fish, and mammals. Mueller and others (1995) reported northern pike (Esox lucius) consistently had the greatest concentrations of $\mathrm{Hg}$, and longnose sucker (Catostomus catostomus) consistently had the greatest concentrations of $\mathrm{Cd}$ and $\mathrm{Cu}$ in Kanuti NWR. Concentrations of metals were not anticipated to be problematic in fish including northern pike and longnose sucker in the Koyukuk and Northern Unit of the Innoko NWRs (Snyder-Conn and others, 1992), although in a subsequent study from these NWRs, concentrations of $\mathrm{Hg}$ and selenium (Se) in fish muscle were greater than background concentrations from other areas (Mueller and others, 1996). The USFWS (Mueller and Matz, 2000) reported Fort Wainwright Army Base and Eielson Air Force Base near Fairbanks were a probable local source of PCB and dichlorodiphenyltrichloroethane (DDT) contamination to the Tanana River and the city of Fairbanks. Another study determined that pesticides and dioxins were not at concentrations of concern in northern pike or burbot from a YRB lake (Snyder-Conn, 1992).

The ADEC was established to conserve and monitor natural resources and the environment within the state (ADEC, 2003b). The ADEC has a fish monitoring project that analyzes methylmercury $(\mathrm{MeHg})$, lead $(\mathrm{Pb})$, and $\mathrm{Cd}$ in multiple marine fish species and northern pike from various lakes within the YRB (ADEC, 2003b). The project was initiated to determine if concentrations of heavy metals in Alaskan fish were below concentrations justifying consumption advisories. The ADEC concluded that concentrations of methylmercury were low and not a public health concern in frequently consumed fish, especially salmon. The ADEC also monitors illegal releases of contaminants including oil and diesel spills into the environment. Many YRB stations sampled in 2002 including near the Charley-Kandik confluence, Fort Yukon, Kotlik, Tanana, and Fairbanks were in the vicinity of airstrips. All of these locations had small spills reported from leaking petroleum tanks, some of which contaminated surrounding soils (ADEC, 2003c). The ADEC has an ongoing investigation of two underground 1 million-gallon tanks (one diesel and one jet fuel) that have leaked into the soil and potentially into the groundwater near Galena. Fairbanks also had multiple reported incidents including pipeline spills and high concentrations of PCBs at some facilities, as well as trichloroethene contamination in groundwater (ADEC, 2004a).

Most YRB contaminant studies have been limited to reporting chemical concentrations. Biomarker studies in the YRB are extremely limited and available only for specific species and locations. Therefore, the primary basis of comparison for biomarkers and contemporary concentrations of contaminants in whole fish is previous BEST LRMN Program data from the MRB (Schmitt, 2002a), RGB (Schmitt and others, 2004) and CRB (Hinck and others, 2004), which included fish species collected in the YRB. 


\section{Major Sources of Contaminants to the Yukon River Basin}

Activities such as mining and logging brought nonindigenous people to the YRB in the 1800s. As a result, military services were brought to the basin to provide law and order to the land, and several large bases and test ranges were established that have contributed to surface water, groundwater, and sediment contamination within the YRB. Many mining districts for gold and other precious metals were established prior to concerns about potential impacts on the environment and have resulted in contaminant problems. In addition, contamination from the transport and exploration of crude oil continues to be a concern throughout Alaska. Air patterns provide a pathway for contaminants sources to enter the region and result in the primary mechanism of pollutant load to the YRB.

\section{Military Facilities}

Active military bases and test ranges are major contributors of non-point source pollution in the YRB (Yukon River Inter-Tribal Watershed Council (YRITWC), 2002). Contaminants at these locations include petroleum products, solvents, pesticides, batteries, and asbestos, although water quality data associated with these non-point source pollutants is lacking.

The U.S. Department of Defense is responsible for environmental restoration of properties known as formerly used defense sites (FUDS) that were previously owned or utilized by the Federal government and under the jurisdiction of the Secretary of Defense. The locations of FUDS were acquired from the U.S. Army Corps of Engineers (USACE) geographic information system (GIS) data layer (USACE, 1999), and information on contaminants associated with FUDS was obtained from the Formerly Used Defense Site Geographic Information System (USACE, 2003). Approximately 113 of 600 FUDS in Alaska are located in the YRB. Most FUDS are positioned along the major river corridors with many in the Tanana River Basin, centrally located near Fairbanks. Other clusters of FUDS are at Delta Junction, Tok, Tanacross, and Galena. At least 12 sites within the basin are known to have hazardous chemical compounds. Sites often contain ordnance, above- and below-ground storage tanks, drums, transformers, landfills, and spill areas. Hazardous materials known to occur at FUDS include trichloroethane (TCE), PCBs, pesticides, radioactive waste, and various petroleum and fuel-related compounds. Seven sites are known or suspected to be disposal sites for chemical weapons. These sites are located at Fort Greely, Fort Wainwright, and the Gerstle River test sites near Healy Lake.

\section{Mining and Extractive Industries}

Mining occurred in the YRB since the mid-1880s discovery of gold in the upper Yukon Basin along the Fortymile River. Early discoveries formed the Fortymile, Eagle, and Circle mining districts prior to the famous Klondike Gold Rush in Canada's Yukon Territory in 1896. Mining activities have since taken place throughout the basin. The most frequently mined commodities are gold and other precious metals, $\mathrm{Pb}$, zinc ( $\mathrm{Zn})$, coal, and more recently diamonds (mostly in the Yukon Territory, Canada). The area between Tanana and Eagle along the U.S.-Canada border continues to be one of the most productive gold producing areas within the basin. Most of the 800 past producing mines located in the U.S. portion of the basin are clustered around Circle, Livengood, Fairbanks, Wiseman, Eagle, and Tanana (Causey, 1998). Almost 90\% of these mines were placer operations with $10 \%$ being lode operations (hard rock mining).

Impacts from unregulated mining and abandoned mines have been documented for more than 100 years in the YRB. Panning and using small sluice boxes were the most common forms of placer mining until the 1920s when mining practices included more destructive methods such as large-scale hydraulic and dredging operations. Today some of these mines are designated USEPA Superfund sites and on the Alaska Department of Energy (DOE) list of contaminated sites. Past mining operations have also contributed to the designation of impaired streams and rivers. Mines that do not fall into a specific category for cleanup or remediation and for which a technically responsible party to maintain or reclaim a site is not named pose additional challenges (YRITWC, 2002). Mining impacts such as habitat disturbance and contamination by trace metals have been cited as adversely affecting anadromous fisheries within the YRB (Buhl and Hamilton, 1990; Salomone and Bergstrom, 2004; USFWS, 1986; 1991).

\section{The Trans-Alaska Pipeline System (TAPS)}

The TAPS was built in 1974-1977 and transports crude oil from the North Slope of Alaska 800 miles south to Port Valdez in Prince William Sound. Over 13 billion barrels of crude oil have moved through TAPS, contributing approximately $11 \%$ of U.S. domestic oil production (USBLM, 2002). The peak daily flow of 2.03 million barrels per day was reached in 1988 with the current rate approximately at 1 million barrels per day (USBLM, 2002). The infrastructure of the pipeline valves and pump stations is strategically placed to facilitate movement of crude oil, isolate sections of the pipeline for maintenance, and minimize the volume of potential spills. There are six pump stations along the TAPS within the YRB; however, some of these stations are being phased out (TAPS Owners, 2001). TAPS crosses numerous creeks and large rivers in the YRB including the Yukon, Koyukuk, Tanana, Tolovana, Chena, Salcha, and Delta, many of which are classified as sensitive and critically sensitive 
habitats to resident and anadromous fisheries (TAPS Owners, 2001). TAPS owners and regulatory agencies identified numerous environmental impacts attributed to the operation of the pipeline (TAPS Owners, 2001; USBLM, 2002). Impacts associated with contaminant inputs relate primarily to oil spills, water discharges, and emission of volatile organic compounds (VOCs) from valves and pump stations. Activities associated with the pipeline that have affected water quality are construction, excavation, and maintenance of the pipeline, material sites and quarries, dewatering, permitted discharges, handling hazardous materials, and spills. However, impacts from these activities have not been associated with irreversible or irretrievable effects on water quality (TAPS Owners, 2001; USBLM, 2002).

Spills were identified as the greatest concern for continued operation of the pipeline (TAPS Owners, 2001; USBLM, 2002). In addition to crude oil, the pipeline also contains hazardous materials and other hydrocarbon-based compounds that are injected into the pipeline to increase flow efficiency and reduce shipping and handling costs (TAPS Owners, 2001). A large oil spill on land would be expected to have localized effects on vegetative communities, birds and mammal populations, and on fish populations in adjacent water bodies (TAPS Owners, 2001; USBLM, 2002). Past operation of the pipeline resulted in numerous spills within the YRB although most were small and localized (TAPS Owners, 2001). Five large spill events occurred within the YRB between 1978 and 2001, resulting in over 24,000 barrels of spilled crude (ADEC, 2003c; TAPS Owners, 2001). The most recent spill associated with TAPS within the YRB (October 4, 2001) resulted in 285,600 gallons of crude being spilled within 1 mile of the Tolovana River (ADEC, 2003c).

Another pipeline that has been associated with contaminants in the YRB is the Haines-Fairbanks Pipeline, originally used by the U.S. Army (1954-1973) to transport petroleum products from Haines to military bases near Fairbanks and into Canada. The U.S. Army reportedly used a mixture of 2,4dichlorophenoxyacetic acid (2,4-D) and 2,4,5-trichlorophenoxyacetic acid $(2,4,5-\mathrm{T})$ to maintain the 326 miles of pipeline corridor (ADEC, 2003d). ADEC recently reported that dioxin contamination associated with this mixture of compounds did not pose a health threat (ADEC, 2004b).

\section{Air Pollution Patterns}

Ocean and atmospheric currents are key pathways for long-range transport of heavy metals, organic pollutants, and radionuclides from industrial and agricultural sources to arctic regions (NCP, 2003). Global air transport of pollutants is the primary mechanism by which the YRB receives the majority of its pollutant load. In general, concentrations of many heavy metals and organic pollutants are declining in northern Canada and Alaska; however, $\mathrm{Hg}$ remains a concern. Mercury is deposited from the atmosphere onto the snow surface during $\mathrm{Hg}$ depletion events and is linked to polar sunrise (Macdon- ald and others, 2003; NCP, 2003). Climate change may also modify atmospheric and ocean currents in the future causing more contaminants to reach the Arctic Ocean (Macdonald and others, 2003; NCP, 2003). In addition, increased temperatures may also lead to an increase in the distribution of wetlands with the melting of permafrost causing sinks for $\mathrm{Hg}$ deposition (Macdonald and others, 2003).

The U.S. National Park Service (USNPS) operates two air deposition monitoring sites within the YRB located near the northeast corner of Denali National Park and Preserve and at Poker Flat northeast of Fairbanks. Both sites are part of the Clean Air Status and Trends Network (CASTNet) that measures dry deposition of atmospheric chemical compounds. Deposition of atmospheric sulfur-containing and nitrogenous compounds was measured following CASTNet Protocols at these sites from July 1998 to June 2001 and a third site located south of the YRB to compare ambient air quality at Denali National Park and Preserve against regional conditions (Air Resource Specialist Inc. and Cahill, 2003). Concentrations of sulfur-containing and nitrogenous compounds from these sites were low compared to other CASTNet sites across the U.S. Seasonal trends and timing of peak concentrations among all three sites for sulfates, sulfur dioxide, particulate nitrate and ammonium, and gaseous nitric acid indicated most of the measured compounds are from regional sources and not local sources. These results support other studies that document global transportation of anthropogenic emissions to the Arctic (AMAP, 1998; Macdonald and others, 2003).

\section{Industrial and Municipal Sources}

Records describing the location of regulated industrial and municipal facilities and the types and amounts of chemicals released were reviewed. Location and discharge data for permitted facilities operating in the U.S. portion of the YRB were derived from the USEPA's TRI and Permit Compliance System (PCS). The TRI database contains basic facility information and chemical data on facilities that release toxic chemicals and compounds to the air, surface water, land, underground injections, and transfers to off-site locations. Only those facilities reporting releases to surface water, air (fugitive and stack), and on-site lands for the years 1997 through 2001 were included in the review for this report (USEPA, 2003b). The PCS database contains information on facilities permitted through the National Pollutant Discharge Elimination System (NPDES) to discharge effluent into navigable waters. Records for all major and minor permitted dischargers located in the YRB were reviewed from the PCS database (USEPA, 2003c).

Fourteen industrial facilities reported releases of toxic chemicals within the YRB during 2001 according to the TRI database (USEPA, 2003b). Eleven TRI facilities are located at or near Fairbanks, Alaska, and other facilities are located at Healy, Delta Junction, and Clear, Alaska. Industry classifications for these facilities include National Security (military bases and training areas), power generation, gold ore mining, 
petroleum refineries and storage, and chemical manufacturing. TRI facilities did not report permitted releases to any streams or rivers although two industrial facilities did report releases to on-site gravel pits and ponds. Facilities associated with Eielson Air Force Base near Fairbanks reported discharging small amounts of $\mathrm{Hg}(0.05 \mathrm{~kg}), \mathrm{Pb}(4.5 \mathrm{~kg})$ and dioxin or dioxin-like compounds $(8 \mathrm{~g})$ into a pond, and a petroleum refinery located in North Pole, Alaska discharged $>340 \mathrm{~kg}$ (in 2000) and 11.3 $\mathrm{kg}$ (in 2001) of benzene, toluene, and xylene compounds to a gravel pit. Large quantities of toxic chemicals and compounds were released in 2001 to on-site lands by six TRI facilities, which were among the top 10 Alaskan facilities for the largest on-site land releases. The Fort Knox mine near Fairbanks reported on-site land releases $>6.8$ million $\mathrm{kg}$ including $\mathrm{Pb}$ (709,609 kg), Cu (331,575 kg), Mn (4,466,977 kg), chromium (Cr) $(865,454 \mathrm{~kg})$, cyanide $(205,930 \mathrm{~kg}), \mathrm{Hg}(205 \mathrm{~kg})$, nickel (Ni), nitrates, and ammonia compounds. Other compounds released by the remaining facilities include toluene, xylene, benzene, cumene, and similar aromatic compounds. Ten TRI facilities including three military bases, two power generators, two mining companies, two petroleum refineries, and a chemical manufacturing company also reported large amounts of toxic chemicals $(362,874 \mathrm{~kg}$ in 2001) released to the air through stack and fugitive emissions and some were among the top 10 air-emitting Alaskan facilities. Barium (Ba) and $\mathrm{Ba}$ compounds were the most abundant toxic chemicals emitted $(175,495 \mathrm{~kg})$ followed by hydrochloric acid $(35,267 \mathrm{~kg})$, hydrogen fluoride $(33,112 \mathrm{~kg})$, chlorine $(31,942 \mathrm{~kg})$, phosphorus $(24,276 \mathrm{~kg})$, and ammonia $(19,595 \mathrm{~kg})$. Only $4.5 \mathrm{~kg}(4 \%)$ of the $\mathrm{Hg}$ emitted was considered fugitive emissions.

There are approximately 563 facilities within the YRB that are permitted to discharge to navigable waters, 548 of which are involved with gold ore production (USEPA, 2003c). The PCS database did not contain parameter discharge information for these operations, and most are involved with placer mining and discharge into small tributaries of the Fortymile, Tolovana, Chatanika, Chena, Tanana, and Koyokuk Rivers, Birch Creek, and the Yukon-Charley River confluence. Only three facilities are listed as a major dischargers $(>3,700,00 \mathrm{~L}$ effluent/day), including a coal mine and a power generator in Healy and the wastewater treatment plant operated by the city of Fairbanks. Three additional power plants, two at Fairbanks and one at Eielson Air Force Base, ultimately discharge into the Chena River. The classification of the remaining NPDES facilities includes three facilities associated with petroleum production and transportation, an apartment complex, and a bus tour line.

\section{Comprehensive Environmental Response, Compensation, and Liability Act (CERCLA - Superfund) Site Summary}

Documentation and Record of Decisions related to USEPA Superfund sites in the YRB were obtained through
USEPA's CERCLIS database (USEPA, 2003d). There are 19 CERCLIS sites located within the YRB, and eight sites are located at Fairbanks or nearby military bases. The remaining sites are located at Delta Junction, Tanacross, Tanana, Galena, Eagle, Denali National Park and Preserve, Tok, and Northway. Thirteen of the sites are associated with past military activities. Other sites are a result of past mining, storage, and landfill activities. Two of the military sites, located on Fort Wainwright and Eielson Air Force Base, are currently on the USEPA Superfund National Priority List (NPL) for cleanup of hazardous substances. Contaminated media at the military sites include soil, groundwater, sediments, and surface water from numerous landfills, chemical dumps, drum burial sites, ordnance and detonations areas, broken pipelines, and spills. Contaminants include heavy metals (As, $\mathrm{Hg}, \mathrm{Cd}$ ), solvents, pesticides, paints, ordnance compounds and volatile organic compounds (benzene, xylene, trichloroethylene, and toluene). The Chena River, a tributary of the Tanana River, flows through some of the contaminated areas within Fort Wainwright. PCB-contaminated fish have been found in a slough that runs through the Eielson Air Force Base NPL site but not in the Tanana River (USEPA, 1998; 1999). A Fairbanks salvage yard situated on the floodplain of the Tanana and Chena Rivers is also on the NPL list for groundwater contamination with TCE and soil contamination with industrial solvents, $\mathrm{PCBs}$, and $\mathrm{Pb}$ although contaminants have not been reported in the rivers (USEPA, 1995; 2003e).

\section{Materials and Methods}

\section{Collection Sites}

Fish were collected at 10 sites in the YRB in Alaska (Fig. 1; Table 1). Four of the ten sites were located on the mainstem Yukon River; two sites were on the Porcupine River; and one site each was on the Ray, Tanana, Tolovana, and Innoko Rivers. Most fish were collected in early May to mid-July in 2002. Station 302 was sampled in mid-August 2002 and Station 305 was sampled multiple times with the last collection occurring in mid-October. Sampling at most sites was completed during one visit spanning 2-4 days.

\section{Target Species and Sampling Strategy}

This study was designed to establish baseline contaminant data for the Yukon River and major tributaries and to compare with other investigations based on composite samples of whole fish while accommodating the biological measurements incorporated into the overall investigation (Schmitt and Dethloff, 2000). Many of these biological measurements are 
Table 1. Stations sampled in 2002 and collection date (first-last) in the Yukon River Basin (YRB). Stations are listed upstream to downstream.

\begin{tabular}{|c|c|c|c|c|}
\hline River & $\begin{array}{l}\text { Station } \\
\text { Number }\end{array}$ & Nearby Landmark & Collection Dates & Latitude, Longitude \\
\hline Yukon & 301 & $\begin{array}{l}\text { Near Charley-Kandik } \\
\text { Confluence, AK }\end{array}$ & $6 / 5 / 02-6 / 6 / 02$ & $65^{\circ} 22^{\prime} 28.56^{\prime \prime} \mathrm{N}, 142^{\circ} 30^{\prime} 20.88^{\prime \prime} \mathrm{W}$ \\
\hline Porcupine & 302 & Fish Hook Bend, AK & $8 / 14 / 02-8 / 16 / 02$ & $67^{\circ} 12^{\prime} 50.94^{\prime \prime} \mathrm{N}, 142^{\circ} 09^{\prime} 58.56^{\prime \prime} \mathrm{W}$ \\
\hline Porcupine & 303 & Fort Yukon, AK & $6 / 12 / 02-6 / 14 / 02$ & $66^{\circ} 35^{\prime} 21.06^{\prime \prime} \mathrm{N}, 145^{\circ} 19^{\prime} 59.40^{\prime \prime} \mathrm{W}$ \\
\hline Ray & 304 & Near the Bridge, AK & $6 / 4 / 02-6 / 7 / 02$ & $65^{\circ} 53^{\prime} 01.26^{\prime \prime} \mathrm{N}, 149^{\circ} 48^{\prime} 00.72^{\prime \prime} \mathrm{W}$ \\
\hline Tanana & 305 & Fairbanks, AK & $\begin{array}{l}5 / 30 / 02-5 / 31 / 02, \\
6 / 28 / 02,10 / 10 / 02\end{array}$ & $64^{\circ} 45^{\prime} 02.52^{\prime \prime} \mathrm{N}, 148^{\circ} 03^{\prime} 15.84^{\prime \prime} \mathrm{W}$ \\
\hline Tolovana & 306 & Tolovana, AK & $6 / 4 / 02-6 / 6 / 02$ & $64^{\circ} 56^{\prime} 56.40^{\prime \prime} \mathrm{N}, 149^{\circ} 44^{\prime} 13.44^{\prime \prime} \mathrm{W}$ \\
\hline Yukon & 307 & Tanana, AK & $6 / 5 / 02-6 / 7 / 02$ & $65^{\circ} 08^{\prime} 09.72^{\prime \prime} \mathrm{N}, 152^{\circ} 24^{\prime} 54.72^{\prime \prime} \mathrm{W}$ \\
\hline Yukon & 308 & Galena, AK & $6 / 10 / 02-6 / 14 / 02$ & $64^{\circ} 41^{\prime} 56.22^{\prime \prime} \mathrm{N}, 156^{\circ} 58^{\prime} 36.30^{\prime \prime} \mathrm{W}$ \\
\hline Innoko & 309 & $\begin{array}{l}\text { Innoko NWR Field } \\
\text { Station, AK }\end{array}$ & $7 / 15 / 02-7 / 17 / 02$ & $63^{\circ} 38^{\prime} 33.66^{\prime \prime} \mathrm{N}, 158^{\circ} 00^{\prime} 43.56^{\prime \prime} \mathrm{W}$ \\
\hline Yukon & 310 & Kotlik, AK & $5 / 9 / 02-5 / 12 / 02$ & $63^{\circ} 02^{\prime} 12.18^{\prime \prime} \mathrm{N}, 163^{\circ} 34^{\prime} 22.56^{\prime \prime} \mathrm{W}$ \\
\hline
\end{tabular}

gender-specific and require live or freshly killed individual fish. To standardize fish health and biomarker results, it was desirable to collect the same species at each site in the basin. Review of the literature determined that one of the most prevalent bottom-dwelling species was longnose sucker and the most prevalent predator species was northern pike. Thus, for this project, longnose suckers and northern pike were the targeted species at all sites. Burbot, a preferred alternate predator species, was collected when northern pike could not be obtained. The collection goal at each site was 10 individual fish of each gender of each species (one predator and one bottom-dwelling species). More than two species were collected at sites with incomplete quotas for the target predator species. Collectors were instructed to obtain adult fish of a size representative of those believed to be present based on extant information and to avoid extremely large or small fish.

\section{Monitoring Methods Overview}

A suite of chemical and biological methods was employed to characterize the exposure of fish to contaminants and the effects of exposure (Schmitt and Dethloff, 2000). The suite included reproductive biomarkers, measures of cytochrome P450 enzyme induction (to assess response to planar halogenated hydrocarbons (PHHs) and polyhalogenated aromatic hydrocarbons (PAHs), fish health assessments, and chemical analyses of fish carcasses (Table 2). Additional information on these methods is available elsewhere (see Schmitt, 2002a; Schmitt and Dethloff, 2000; Whyte and others, 2000; Whyte and others, 2004 and references cited therein). Concurrent determination of tissue residue concentrations along with the suite of fish health indicators and reproductive biomarkers supports the interpretation of relationships between exposure and biological responses.

The organochlorine and elemental contaminants analyzed in composite samples (Table 3) were selected to provide the maximum amount of information on accumulative contaminants of potential concern at minimal cost and to maintain continuity with the historical NCBP database (Schmitt, 2002a). Extracts of the composite samples were screened with the H4IIE rat hepatoma cell bioassay (Whyte and others, 2004), which responds to planar PHHs (Table 4). In addition, the livers of the individual fish were assayed for ethoxyresorufin $O$-deethylase (EROD) activity, which indicates recent exposure to exogenous AhR ligands including PHHs and PAHs (Kennedy and Jones, 1994; Pohl and Fouts, 1980; Whyte and others, 2000). Together, these assays and analyses allow estimation of the relative concentrations of potential biological effects of $\mathrm{PHH}$ and $\mathrm{PAH}$, without the expense of instrumental analyses for these compounds (Table 4; Schmitt and others, 2002a).

Measures of fish health at various levels of biological organization, immune system responses, and reproductive status were included in the suite of indicators to address potential impacts from nonaccumulative contaminants and contaminant 
Table 2. Methods incorporated into the YRB project in 2002.

\begin{tabular}{|c|c|c|c|c|}
\hline Method & Description & $\begin{array}{l}\text { Tissue(s) } \\
\text { Examined }\end{array}$ & Sensitivity & $\begin{array}{c}\text { Primary } \\
\text { Reference(s) }\end{array}$ \\
\hline Histopathology & $\begin{array}{l}\text { Microscopic examination for } \\
\text { the presence of lesions; can } \\
\text { provide early indication of } \\
\text { chemical exposure }\end{array}$ & $\begin{array}{l}\text { Liver, gill, } \\
\text { gonads, spleen, } \\
\text { and kidney }\end{array}$ & $\begin{array}{l}\text { Overall organism } \\
\text { health and } \\
\text { contaminants }\end{array}$ & $\begin{array}{l}\text { Hinton and others (1992); } \\
\text { Hinton (1993); Goodbred } \\
\text { and others (1997) }\end{array}$ \\
\hline $\begin{array}{l}\text { Ethoxyresorufin } O- \\
\text { deethylase (EROD) } \\
\text { activity }\end{array}$ & $\begin{array}{l}\text { Enzyme induction by planar } \\
\text { hydrocarbons }\end{array}$ & Liver & $\begin{array}{l}\text { PCBs; } \\
\text { chlorinated, } \\
\text { dioxins, and } \\
\text { furans; PAHs }\end{array}$ & $\begin{array}{l}\text { Pohl and Fouts (1980); } \\
\text { Kennedy and Jones (1994); } \\
\text { Whyte and others (2000) }\end{array}$ \\
\hline $\begin{array}{l}\text { Macrophage } \\
\text { aggregate analysis }\end{array}$ & $\begin{array}{l}\text { Macrophages are important in } \\
\text { the immune system, serving as } \\
\text { a first line of defense for the } \\
\text { organism and as an antigen } \\
\text { processing cell }\end{array}$ & Spleen & $\begin{array}{l}\text { Multiple } \\
\text { contaminants } \\
\text { including PAHs } \\
\text { and metals }\end{array}$ & $\begin{array}{l}\text { Blazer and others (1994); } \\
\text { Blazer and others (1997) }\end{array}$ \\
\hline H4IIE bioassay & $\begin{array}{l}\text { A screening tool to determine } \\
\text { the presence of certain classes } \\
\text { of planar halogenated } \\
\text { compounds }\end{array}$ & $\begin{array}{l}\text { Whole fish } \\
\text { (composite } \\
\text { samples) }\end{array}$ & $\begin{array}{l}\text { PCBs; } \\
\text { chlorinated } \\
\text { dioxins and } \\
\text { furans }\end{array}$ & $\begin{array}{l}\text { Tillitt and others (1991); } \\
\text { Whyte and others (2004) }\end{array}$ \\
\hline Vitellogenin & $\begin{array}{l}\text { A precursor of egg yolk, } \\
\text { normally synthesized in the } \\
\text { liver of female fish }\end{array}$ & Blood plasma & $\begin{array}{l}\text { Endocrine- } \\
\text { modulating } \\
\text { substances }\end{array}$ & Denslow and others (1999) \\
\hline $\begin{array}{l}\text { Steroid hormones } \\
\text { (estradiol and } \\
\text { testosterone) }\end{array}$ & $\begin{array}{l}\text { Determine reproductive health } \\
\text { and status }\end{array}$ & Blood plasma & $\begin{array}{l}\text { Endorcrine- } \\
\text { modulating } \\
\text { substances }\end{array}$ & $\begin{array}{l}\text { Guillette and others (1994); } \\
\text { Goodbred and others } \\
\text { (1997) }\end{array}$ \\
\hline Chemical analyses & $\begin{array}{l}\text { Organochlorine chemical } \\
\text { residues and elemental } \\
\text { contaminants }\end{array}$ & $\begin{array}{l}\text { Whole fish } \\
\text { (composite } \\
\text { samples) }\end{array}$ & Specific analytes & $\begin{array}{l}\text { Schmitt and others } \\
\text { (1999a) }\end{array}$ \\
\hline Somatic indices & $\begin{array}{l}\text { The relative mass of some } \\
\text { organs is often indicative of } \\
\text { chemical exposure }\end{array}$ & $\begin{array}{l}\text { Gonads, spleen, } \\
\text { liver }\end{array}$ & $\begin{array}{l}\text { Overall organism } \\
\text { health }\end{array}$ & Grady and others (1992) \\
\hline $\begin{array}{l}\text { Necropsy-based fish } \\
\text { health } \\
\text { assessment }\end{array}$ & $\begin{array}{l}\text { Visual assessment of } \\
\text { external/internal anomalies (for } \\
\text { example, lesions, parasites, } \\
\text { tumors), which may indicate } \\
\text { contaminant-related stress }\end{array}$ & All & $\begin{array}{l}\text { Overall organism } \\
\text { health }\end{array}$ & $\begin{array}{l}\text { Goede }(1988,1996) ; \\
\text { Adams and others (1993); } \\
\text { Adams (1990) }\end{array}$ \\
\hline
\end{tabular}

mixtures (Table 2). Measures of fish health included 1) gross observation of abnormalities; 2) condition and organosomatic indices; and 3) histopathological examination (Hinton and others, 1992; Hinton, 1993; Goodbred and others, 1997; Myers and Fournie, 2002). Gross observations and determination of indices based on relative fish and organ sizes such as condition factor (CF), hepatosomatic index (HSI), and splenosomatic index (SSI) are relatively simple and indicative of cumulative, organism-level changes (Grady and others, 1992). However, they are nonspecific in terms of causal mechanisms and may reflect early, subtle alterations and may foreshadow subsequent effects at the individual or population level.

Immune system indicators included the measurement of macrophage aggregates (MA) in preserved spleen and anterior kidney histology (Table 2). Macrophage aggregates, also known as melanomacrophage centers, are discrete aggregations of pigment-bearing macrophages found in the spleen, kidney, and sometimes liver of advanced teleosts (Agius, 1980). These specialized cells are thought to be responsible for centralizing foreign material and debris for destruction, detoxification or reuse, storing waste products, contributing to the immune response, and storing/recycling Fe (Ellis and others, 1976; Ferguson, 1976). Although they may be affected by a variety of factors, MA measurements have responded to contaminant exposure in both field and laboratory studies (reviewed by Wolke (1992) and Blazer and others (1997)).

Measures of reproductive condition included plasma vitellogenin (vtg) concentrations, gonadosomatic index (GSI), and gonadal histopathology (Table 2). Although reproductive condition in fish can be influenced by many factors (for 


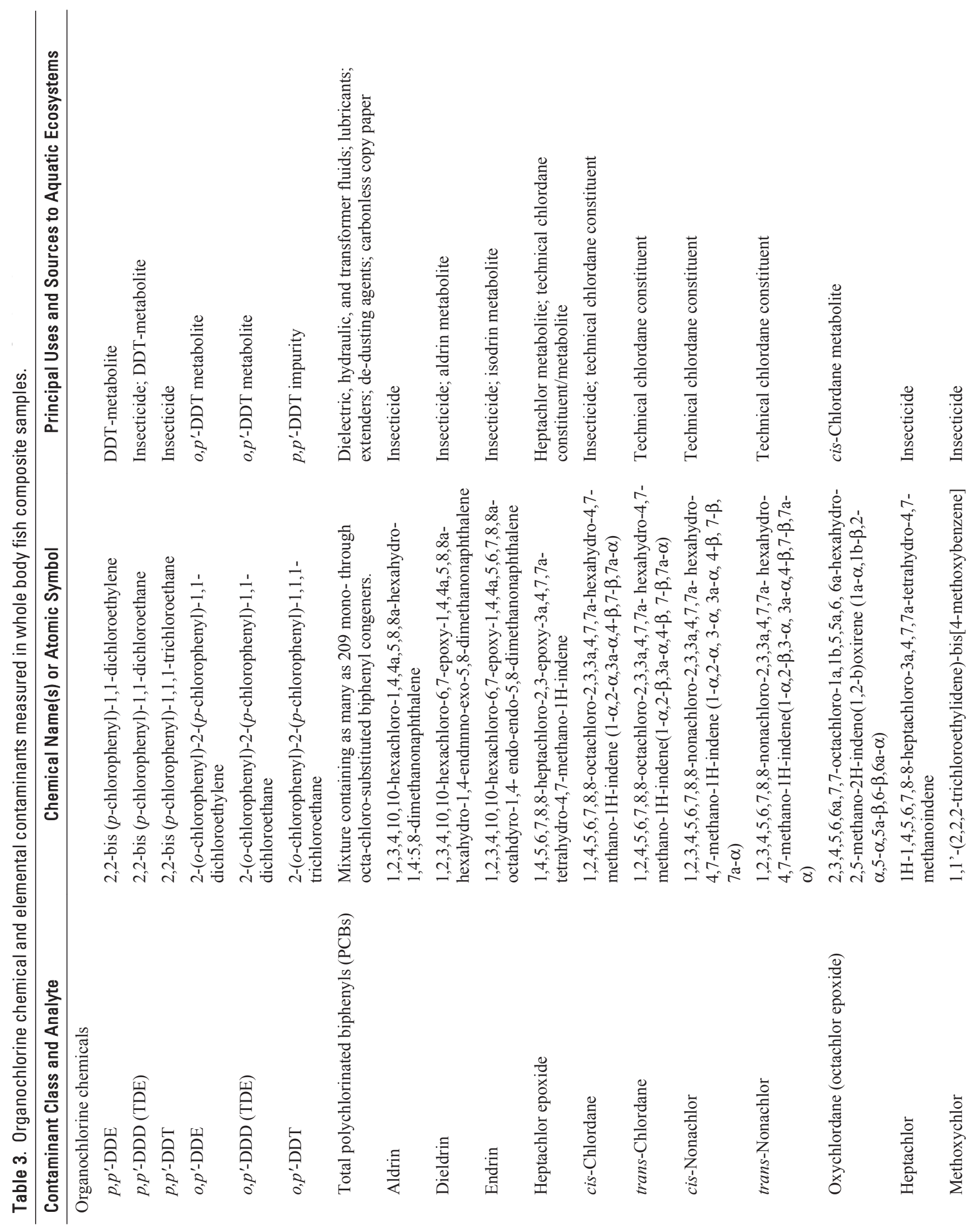




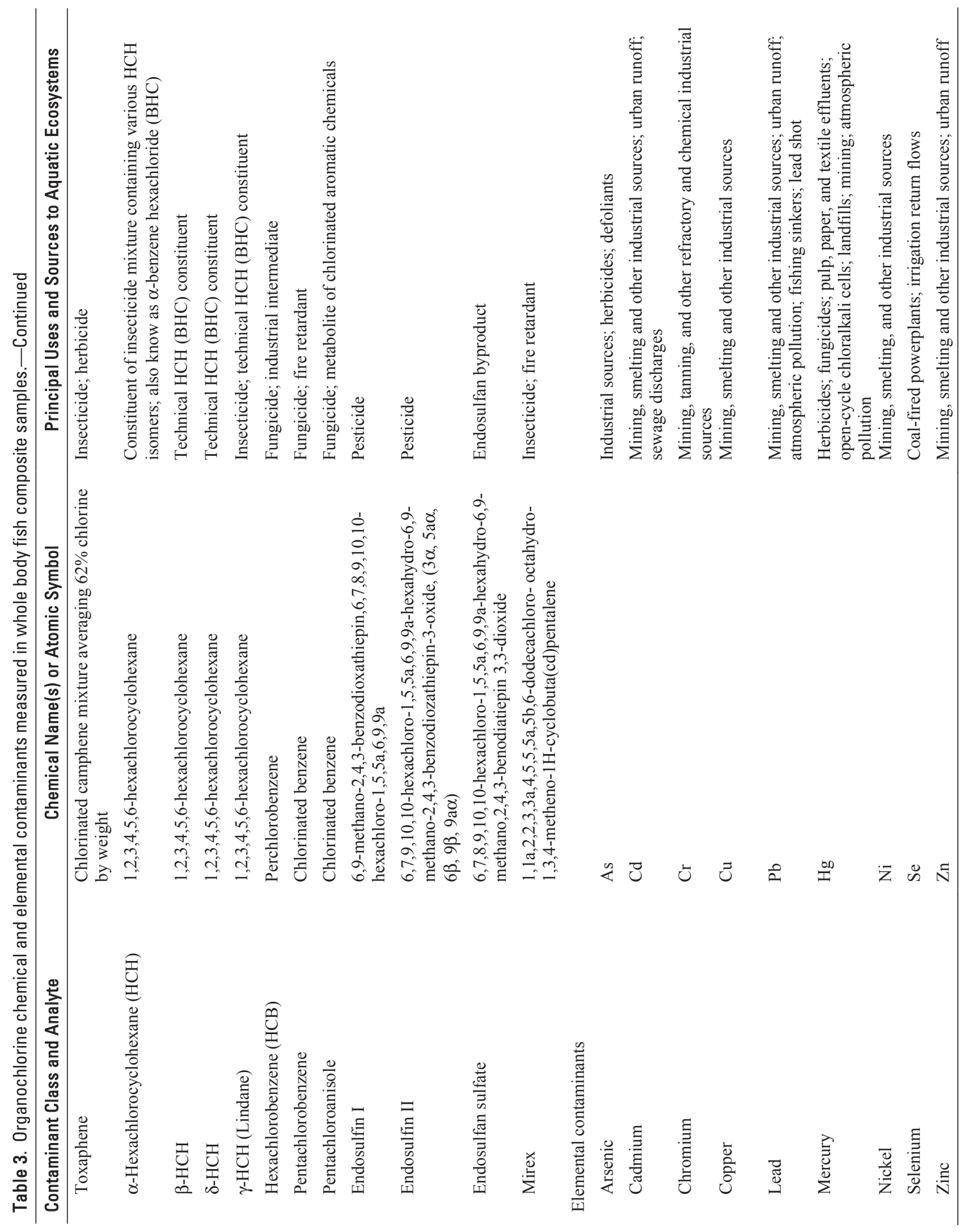


Table 4. Monitoring and assessment strategy for polycyclic aromatic and polyhalogenated hydrocarbons (PAHs and PHHs). ${ }^{a}$ Total PCBs were determined by gas chromatography with electroncapture detection. ${ }^{b} 7$-ethoxyresorufin 0 -deethylase. ${ }^{c} \mathrm{H} 4 \mathrm{IIE}$ bioassay was performed after reactive cleanup to remove AhR-active PAHs. ${ }^{\mathrm{d}}$ And other planar organic compounds. + responds; - does not respond; ${ }^{*}$ AhR-active isomers and congeners only.

\begin{tabular}{lccc}
\hline & \multicolumn{3}{c}{ Contaminants } \\
\cline { 2 - 4 } Endpoint & PCBs & $\begin{array}{c}\text { PCDDs \& } \\
\text { PCDFs }\end{array}$ & PAHs $^{d}$ \\
\hline $\begin{array}{l}\text { GC-ECD }^{\mathrm{a}} \\
\text { (carcass) }\end{array}$ & + & - & - \\
$\begin{array}{l}\text { EROD } \\
\text { activity }\end{array}$ & $*$ & $*$ & $*$ \\
$\begin{array}{l}\text { (liver) } \\
\text { H4IIE } \\
\text { bioassay } \\
\text { (carcass) }\end{array}$ & $*$ & $*$ & \\
\hline
\end{tabular}

example gender, age, reproductive stage, season, water temperature), contaminants, particularly estrogen mimics, have been shown to impact reproduction in laboratory and field studies (Allen and others, 1999; Gimeno and others, 1998). Estrogen mimics are capable of stimulating the production of $\mathrm{vtg}$, a precursor of yolk protein, in the livers of oviparous vertebrates. A number of endocrine-disrupting compounds have been shown to induce abnormal vitellogenesis (Servos, 1999; Tyler and others, 1998). Vitellogenin production is normally associated with female fish; however, it can be produced in males if estrogen or an estrogen-like chemical is present. The detection of levels typical of early- to mid-vitellogenic females in male fish has been associated with exposure to exogenous estrogens (Bowman and others, 2002; Denslow and others, 1999; Folmar and others, 1996; Folmar and others, 2000; 2001). To document these and other possible alterations and to establish baseline concentrations, vtg was measured in both male and female fish. GSI and gonadal histopathology (stage, presence of atretic oocytes, and intersex conditions [presence of female reproductive tissue in males or vice versa]) were also assessed as measures of reproductive health and status. The GSI relates the proportional size of the gonad to the body size and may reflect changes resulting from a variety of physiological factors such as reproductive stage and environmental factors, including exposure to contaminants. Elevated occurrence of atretic (reabsorbed and/or degenerating) eggs has been noted in fish exposed to contaminants (Cross and Hose, 1988; Johnson and others, 1988), although other factors may also be involved. Feminization of male fish (that is, intersex condition) has been reported in laboratory and field studies of contaminants (Allen and others, 1999; Gimeno and others, 1997; Gimeno and others, 1998; Jobling and others, 1998).

\section{Field Procedures}

Teams of three to seven biologists collected and processed the fish. The leader of each team (and other team members) had participated in a training session to gain familiarity with collection, dissection, storage, handling, and recording protocols. Sampling commenced in May 2002 and was completed in July 2002 with the exception of Station 305, which was completed in early October 2002. Teams spent 2-5 days at each station.

\section{Fish Collection}

Fish were collected by angling, gill nets, and fyke nets. Collection was generally conducted along the shoreline or backwater areas of the river being sampled. More than 10 fish of a given species and gender were collected at some sites if gender was not easily discernible in the field. Global Positioning System (GPS) coordinates were obtained at the upstream and downstream locations at the sampling site where fish were collected. Fish were held in live wells or tethered in the water, transported to processing sites, and usually processed within a few hours of collection.

\section{Sample Processing}

The methods used to process the fish have been fully described (Table 2; Schmitt and others, 1999a; Schmitt and Dethloff, 2000). Briefly, a live fish was selected and identified to species. A blood sample was collected from the posterior caudal artery and vein with a heparinized needle and syringe and placed on wet ice. From this sample, plasma was later obtained for determination of vtg and steroid hormone concentrations. The fish was then weighed, measured, and killed. Observations of external features were recorded, and tissue anomalies were removed by dissection and preserved in $10 \%$ neutral buffered formalin (NBF) for histopathological analysis. The abdominal cavity of the fish was dissected open and the liver (in species with a discrete liver), spleen, and gonads were removed and weighed. Liver weights for longnose sucker were not determined because this species has a dispersed hepatic organ. The liver, gall bladder, posterior and anterior kidneys, gonads, mesenteric fat (in certain species), and spleen were examined, and the gender of the fish was visually determined. Pieces of liver were collected and immediately flash-frozen in liquid nitrogen dry shipper and remained there until sample shipment; these samples were later analyzed for EROD activity. Samples of gonad, kidney, spleen, and additional pieces of liver were collected and preserved in $10 \%$ NBF for histopathological examination, gender confirmation (gonad), and macrophage aggregate analysis (spleen). Upon completion of the internal examination and dissection, otoliths or scales were collected for age determination. Remaining 
tissues (those not frozen or fixed) were placed back into the body cavity and the entire fish was wrapped in aluminum foil. The wrapped carcass was placed in a polyethylene bag with other carcasses of the same species and gender and labeled. These samples were chilled and later frozen for analysis of organochlorine chemical and elemental contaminants and dioxin-like activity (with the H4IIE bioassay). The entire field procedure was typically conducted in 15-20 min (per fish), and tissue samples, especially liver for EROD analysis, were collected and frozen as rapidly as possible. Blood samples were centrifuged and the plasma was aspirated and frozen in dry ice following the processing of the fish.

\section{Laboratory Analysis}

Composite fish samples were shipped frozen in dry ice to the Columbia Environmental Research Center (CERC) of the U.S. Geological Survey (USGS). CERC performed analyses of composite fish samples for organic and elemental contaminants and completed quality assurance (QA) and quality control $(\mathrm{QC})$ procedures. Fish were composited, homogenized, and lyophilized by LET, Inc. (Columbia, MO) according to protocols given by CERC. Spike recoveries and moisture loss during storage were not reflected in the reported results. Cryogenically frozen liver samples for EROD analysis were also shipped (in liquid nitrogen dry shippers) to CERC for analysis. Cryogenically frozen plasma samples were similarly shipped to the Protein Chemistry Research Laboratory of the University of Florida for analysis of vtg and the Florida Integrated Science Center of the USGS for steroid hormones analysis. Preserved tissue samples were shipped to the Leetown Science Center (LSC) of the USGS and Northwest Fisheries Science Center of the National Oceanic and Atmosphereic Administration (NOAA) for histopathological analysis. Information on these latter procedures are given by Blazer and others (2002) and McDonald and others (2002).

Otoliths were processed for age determination in northern pike following modified procedures from Chilton and Beamish (1982) and Haas and Recksiek (1995). Scales were processed for age determination as described by Jearld (1983), with age (years) estimated from the number of completed annuli when otoliths were not available.

\section{Composite Sample Preparation}

Carcass samples were shipped to and stored frozen $\left(-20^{\circ}\right.$ C) at CERC. Individual fish carcasses were composited by gender and species and homogenized. One subsample $(\sim 100$ $\mathrm{g}$ ) of the composite was refrozen for analysis of moisture content and the elemental contaminants, and a second sub-sample $(\sim 100 \mathrm{~g})$ was refrozen for analysis of lipid content, organic contaminants, and the H4IIE bioassay. Details of these procedures are given in the following sections.

\section{Elemental Contaminants and Moisture Content}

For the determination of aluminum (Al), Ba, beryllium (Be), $\mathrm{Cd}, \mathrm{Cr}, \mathrm{Cu}, \mathrm{Fe}, \mathrm{Pb}$, magnesium ( $\mathrm{Mg}$ ), Mn, molybdenum (Mo), Ni, strontium ( $\mathrm{Sr}$ ), vanadium (V), and $\mathrm{Zn}$, digestates were prepared from whole body fish suitable for analysis by a semi-quantitative inductively coupled plasma mass spectrometry (ICP-MS) metals scan. A homogenized aliquant of each dried sample $(\sim 0.25 \mathrm{~g})$ was heated with $6 \mathrm{~mL}$ of nitric acid in a sealed low-pressure Teflon ${ }^{\circledR}$ vessel in a microwave oven. The cooled digestate liquid was transferred to a $125 \mathrm{~mL}$ polyethylene bottle and ultrapure water $(>10 \mathrm{megOhm} / \mathrm{cm})$ was added, yielding a final weight of $101.5 \mathrm{~g}(100 \mathrm{~mL})$. The final acid matrix was $6 \% \mathrm{HNO}_{3}$. An additional tissue aliquant $(\sim 0.5 \mathrm{~g})$ of each dried tissue sample was subjected to a magnesium nitrate-nitric acid dry ashing procedure followed by hydrochloric acid $(\mathrm{HCl})$ reduction for the determination of As and Se. The dry ashing procedure consisted of three steps: 1) boiling with nitric acid for solubilization and partial oxidation; 2) $500^{\circ} \mathrm{C}$ ashing with magnesium nitrate to complete the oxidation and decompose remaining organic matter; and 3) heating with $\mathrm{HCl}$ to dissolve the ash and reduce $\mathrm{Se}$ and $\mathrm{Se}^{+4}$ oxidation state required for hydride generation. Following the $\mathrm{HCl}$ reduction, digestates were diluted to $\sim 100 \mathrm{~mL}$ with de-ionized water, which yielded a final acid matrix of $10 \%$ $\mathrm{HCl}$. For the determination of $\mathrm{Hg}$ in fish samples, there was no chemical preparation (digestion) because the dried sample was thermally decomposed in the analysis.

Concentrations of $\mathrm{Al}, \mathrm{Ba}, \mathrm{Be}, \mathrm{Cd}, \mathrm{Cr}, \mathrm{Cu}, \mathrm{Fe}, \mathrm{Pb}, \mathrm{Mg}$, $\mathrm{Mn}, \mathrm{Mo}, \mathrm{Ni}, \mathrm{Sr}, \mathrm{V}$, and $\mathrm{Zn}$ were determined by ICP-MS using the semi-quantitative scan mode. All samples were diluted $10 \mathrm{X}$ by a CETAC ASD-500 auto-diluter as part of the analytical sequence. Internal standards were germanium $(\mathrm{Ge})(50$ $\mathrm{ng} / \mathrm{g})$, rhodium (Rh) $(10 \mathrm{ng} / \mathrm{g})$, and thorium $(\mathrm{Th})(10 \mathrm{ng} / \mathrm{g})$. The external standard consisted of a NIST traceable reference solution to which five elements (praseodymium (Pr), terbium $(\mathrm{Tb})$, thulium $(\mathrm{Tm})$, tantalum $(\mathrm{Ta})$, and gold $(\mathrm{Au})$ ) were added for improved calibration in the rare earth region of the mass spectral range. Mercury was determined by thermal combustion amalgamation atomic absorption (AA) with a direct mercury analyzer (Milestone DMA-80). The determination of As and Se in dried ash samples was accomplished by flow injection hydride generation atomic absorption spectroscopy. The digestates were mixed with $\mathrm{HCl}$ carrier solution and reduced by sodium tetrahydridoborate which has been stabilized with sodium hydroxide. The resulting volatile hydrogen selenide or arsenide was transferred with argon carrier gas into a heated quartz cell mounted on an atomic absorption spectrophotometer for decomposition and measurement.

Limits of detection (LODs) were determined individually for each sample but were nominally $0.026 \mu \mathrm{g} / \mathrm{g}$ dry weight (dw) for As, $0.013 \mu \mathrm{g} / \mathrm{g} \mathrm{dw}$ for Se, and $0.002 \mu \mathrm{g} / \mathrm{g} \mathrm{dw}$ for $\mathrm{Hg}$. Most elemental concentrations determined with the semiquantitative scan ICP-MS were below the reporting limits. The LODs, as well as the analytical results, were converted 
to wet-weight (ww) concentrations for statistical analysis and reporting.

\section{Organochlorine Contaminants and Lipid Content}

Residues of organochlorine pesticides (OCs) and PCBs were measured in the YRB composite fish samples using trace organic analysis methods that included extracting and purifying the residues and was followed by quantification with high resolution capillary gas chromatography with electron capture detection. Targeted OCs included the following: pentachlorobenzene, hexachlorobenzene, pentachloroanisole, alpha-BHC, beta-BHC, lindane, delta-BHC, heptachlor, heptachlorepoxide, aldrin, dieldrin, endrin, oxychlordane, cis-chlordane, trans-chlordane, cis-nonachlor, trans-nonachlor, $o, p$ '-DDE, $o, p$ '-DDD, $o, p^{\prime}$-DDT, $p, p^{\prime}$-DDE, $p, p^{\prime}$-DDD, $p, p^{\prime}$-DDT, endosulfan I and II, endosulfan sulfate, methoxychlor, mirex, and toxaphene (Table 3). PCB congeners comprising $>95 \%$ of the PCB mass in the composite samples were individually quantified ( $n>140)$ and summed to attain a total PCB concentration. The PCB congeners as identified by the International Union of Pure and Applied Chemistry (IUPAC) included the following: 001, 003, 004, 005, 006, 007, 008, 009, 010, 015, 016, 017, 018, 019, 020, 022, 024, 025, 026, 027, 028, 031, 032, 033, 034, 035, 037, 040, 041, 042, 043, 044, 045, 046, 047, 048, 049, 051, 052, 053, 054, 055, 056, 059, 060, 063, 064, 066, 067, 069, 070, 071, 072, 074, 075, 082, 083, 084, 085, 086, 087, 090, 091, 092, 094, 095, 096, 097, 099, 101, 102, 105, $109,110,114,115,117,118,119,122,123,124,128,129$, $130,131,132,133,134,135,136,137,138,139,141,144$, $146,147,149,151,153,156,157,158,163,164,166,167$, $170,171,172,173,174,175,176,177,178,179,180,183$, $185,187,189,190,191,193,194,195,196,197,198,199$, 200, 201, 202, 203, 204, 205, 206, 208, and 209.

The analytical procedure began with blending $100 \mathrm{~g}$ anhydrous sodium sulfate with a $25 \mathrm{~g}$ portion of composite sample. The targeted chemicals were then extracted from the dried sample with a 1-h soaking in glass columns and elution with dichloromethane. The extract was quantitatively split into the following portions: H4IIE bioassay $(80 \%, 20 \mathrm{~g}$ equivalent of fish tissue); OC/PCB/toxaphene analyses $(8 \%$, $2 \mathrm{~g})$; percent-lipid determination $(2 \%, 0.5 \mathrm{~g})$; and archive $(10 \%, 2.5 \mathrm{~g})$. Percent lipid was measured gravimetrically after evaporation of the extraction solvent. Lipids were removed from the bioassay portions of the extract by digestion using acidic and basic reactive silica gels. The analytical portion of the extract was spiked with the following chemical standards to track method recoveries: PCB 029 (2,4,6-trichlorobiphenyl), PCB 155 (2,2',4,4',6,6'-hexachlorobiphenyl), PCB 204 (2,2',3,4,4',5,6,6'-octachlorobiphenyl), tetrachloro-m-xylene, and dibutylchlorendate. PCB 029 is representative of more volatile early-eluting $\mathrm{PCBs}\left(\mathrm{Cl}_{1}-\mathrm{C}_{13}\right)$; $\mathrm{PCB} 155$ is representative of mid-range eluting congeners $\left(\mathrm{Cl}_{4}-\mathrm{Cl}_{6}\right)$; and PCB 204 is less volatile and representative of later-eluting $\mathrm{PCBs}\left(\mathrm{Cl}_{7}\right.$
$\left.-\mathrm{Cl}_{10}\right)$. Each of these standards was used to monitor recovery of their respective PCB ranges.

Method performance was monitored by quality control samples [triplicates, blank fish tissues (negative control bluegill (Lepomis macrochirus)), blank reagents (procedural blank), and spiked blank fish] included with each analytical sample batch. The spiked samples received a 1:1:1:1 ratio mixture of Aroclors 1242, 1248, 1254, 1260 (1000 ng/g fish tissue), the $27 \mathrm{OCs}$ (each $20 \mathrm{ng} / \mathrm{g}$ fish tissue) that included a technical mix of toxaphene $(50 \mathrm{ng} / \mathrm{g}$ fish tissue). Triplicate analyses of each YRB species (northern pike, longnose sucker, and burbot) were conducted.

The analytical portion of the extract was purified by removing interfering co-extracted lipids and biogenic materials prior to the gas chromatographic quantification of the targeted OCs. The bulk of the interferences were removed by low-pressure size-exclusion chromatography (LPSEC), specifically, a $90 \mathrm{~cm}$ x 4cm SX-3 column with dichloromethane elution. High performance SEC (HPSEC) was used to remove residual interferences. A two-layered octadecyl silica/activated silica gel column was used to separate the OCs from the PCBs prior to gas chromatography (GC) analysis that produced two fractions: Fraction-1 (F1) containing PCBs with six OCs and Fraction-2 (F2) containing the remainder of the OCs.

Fraction-1 and F2 extracts were adjusted to final volumes of $2 \mathrm{~mL}$, and PCB 030 and 207 were added as instrumental internal standards. Individual PCB congeners were measured in F1, and individual OC pesticides were measured in both fractions. Hewlett-Packard (HP) 5890 Series II Gas Chromatographs with cool on-column capillary injection systems and HP 7673 autosamplers were used. A 3-m section of 0.53 $\mathrm{mm}$ i.d. uncoated deactivated capillary retention gap was attached by a Press-Tight union to each of the analytical columns that were $60 \mathrm{~m} \times 0.25 \mathrm{~mm} \times 0.25 \mu \mathrm{m}$ DB-5 (5\% phenyl-, 95\% methylsilicone) and DB-17 (50\% phenyl-, 50\% methylsilicone). The GC conditions for the $\mathrm{PCB}$ analysis were: $\mathrm{H}_{2}-$ carrier gas regulated at $25 \mathrm{psi}$, initial temperature $60^{\circ} \mathrm{C}$, immediately ramped to $150^{\circ} \mathrm{C}$ at $15^{\circ} \mathrm{C} / \mathrm{min}$, then ramped to $260^{\circ} \mathrm{C}$ at $1^{\circ} \mathrm{C} / \mathrm{min}$, and finally ramped to $300^{\circ} \mathrm{C}$ at $10^{\circ} \mathrm{C} / \mathrm{min}$, and held for $15 \mathrm{~min}$; Electron Capture Detector (ECD) at $330^{\circ} \mathrm{C}$. The capillary GC/ECD data were collected, archived in digital form, and processed using a Perkin-Elmer chromatography data system and version 6.2 of TotalChrom Workstation. The method detection limits (MDLs) for each targeted contaminant were based on procedural blank $(\mathrm{PB})$ results following to the method described by Keith (1991). A mean and standard deviation (SD) are based on several years of PB results $(n>10)$. This was used to produce a long-term MDL $\left[\mathrm{MDL}=\right.$ mean $_{\mathrm{PB}}$ $\left.+3\left(\mathrm{SD}_{\mathrm{PB}}\right)\right]$ and a method quantitation limit $\left[\mathrm{MQL}=\right.$ mean $_{\mathrm{PB}}$ $\left.10(\mathrm{SD})_{\mathrm{PB}}\right)$ ] (Childress and others, 1999). The precision of the methods and percent recoveries are presented in Appendix 1.

PCB congeners were matched and identified on the 60-m DB-17 column, and the total PCB concentration was determined as a sum of congeners ( $>95 \%$ of the PCB mass). A mixture of several Aroclors was used to produce the PCB con- 
gener calibration standards. These standards were quantified based on primary PCB standards (Accustandard, New Haven, CT) and used as secondary standards. Up to nine levels of calibration for each individual congener were used to quantify the congeners in the YRB samples. The calibration curve for total PCB concentrations in the solutions ranged from 10 to 8000 ng/mL (10 - 8000 ng/g ww). Dual-column data were used to confirm OC pesticide identities using different phases of GC columns to produce unique, complementary retention times. An OC retention time and quantity based on one column analysis was matched with retention time and quantity on the second column. The calibration ranged from 0.1 to 80 ng/mL (0.1 - 80 ng/g ww).

Total toxaphene concentrations were determined in F2 on the $60-\mathrm{m}$ DB-17 column by quantifying components that matched relative retention times of components of the technical 4-40 ng/g toxaphene standard. Concentrations of toxaphene in the YRB samples ranged from $<11 \mathrm{ng} / \mathrm{g}$ to three times the MDL (34 ng/g). The pattern of the very small component peaks varied among samples. This variation among fish samples has been described previously in the arctic (Bidleman and others, 1993). The GC/ECD method met the data quality objectives set for this study and provided a sufficiently low LOD. However, there are other methods for determining concentrations of toxaphene $<11 \mathrm{ng} / \mathrm{g}$ (Muir and de Boer, 1993).

\section{H4IIE Rat Hepatoma Cell Bioassay}

The subsamples for H4IIE analysis were kept frozen at CERC until sample processing. Full details of processing have been previously described (Schmitt and others, 2002a). Briefly, samples were thawed, homogenized, and extracted from a column with methylene chloride. Percent lipid was determined on a $1 \%$ portion of the extract. The remainder was concentrated and cleaned up by two-stage column chromatography. Extracts were evaporated, redissolved with isooctane and ampulated. Matrix QC of prepared samples (blanks and spikes) included ground tissues from laboratory-raised bluegill and samples of a CERC standard positive control tissue (common carp from Saginaw Bay, MI). These QC samples were processed concurrently with the YRB samples.

The H4IIE bioassay was performed on the extracts according to the method of Tillitt and others (1991). These samples were screened in the H4IIE bioassay to determine if a full dose assessment was required. The screening procedure dosed the extracted samples and QC concentrates in quadruplicate with no accompanying serial dilution, and the 2,3,7,8tetrachlorodibenzo- $p$-dioxin (TCDD) standard was dosed in a 3 -fold serial dilution.

The H4IIE rat hepatoma cells were seeded at 23,000 cells/well in $300 \mu \mathrm{L}$ of D-MEM culture media (Tillitt and others, 1991) and allowed to proliferate for $24 \mathrm{~h}$. The cells were then dosed with sample extracts or standards in isooctane and incubated for $72 \mathrm{~h}$ to allow for maximal EROD induction. A standardized TCDD solution was used to generate an analytical dose-response curve. A total of five dose-response curves were analyzed on the assay date. A linear regression was performed on each sample well to obtain the slope and estimate the rate of the reaction ( $\mathrm{pmol} / \mathrm{min})$. The amount of protein in each well was determined by the fluorescamine assay (Lorenzen and Kennedy, 1993) and the values used to normalize dose to each well and EROD activity. The reaction rate observed in each well was normalized according to the measured protein content, generating a value of specific activity (pmols resorufin formed/minute/mg of protein). The reaction rate in each well was then divided by the measured dose given to each well (gram equivalents/mg) to result in specific activity per min per gram equivalent (g.eq.) dosed. Reported results are the average of four replicate concentrate doses. The mean EROD reaction rate ( $\mathrm{pmol} / \mathrm{min} / \mathrm{g}$.eq.) was divided by the average initial slope obtained for the TCDD standard curves, resulting in a measure of an equivalent dose of TCDD (TCDD-EQ) for each sample.

\section{EROD Activity}

Cryogenically frozen liver samples were stored at $-80^{\circ} \mathrm{C}$ until the preparation of microsomal fractions that were used the day they were prepared. The kinetic microsomal assays were conducted in 96-well microtiter plates (Hinck and others, 2003; Whyte and others, 2000). Briefly, triplicate determinations of EROD activity were performed on $10-\mu \mathrm{L}$ portions of each microsomal preparation, and mean EROD activity was reported. Protein content was determined using the fluorescamine protein assay (Lorenzen and Kennedy, 1993) in the same 96-well microtiter plate as the EROD analyses. A positive control material, liver microsomes from male Sprague Dawley rats injected with $500 \mathrm{mg} / \mathrm{kg}$ of Aroclor 1254, was also analyzed. A linear regression was performed on the data from each well to determine an EROD rate (pmol/min) along with its associated estimate of variance. The amount of protein was used to normalize EROD activity ( $\mathrm{pmol} / \mathrm{min} / \mathrm{mg}$ ) in each well. A rigorous QA program was followed for the EROD assays (Hinck and others, 2003). The LOD was calculated by adding the average basal EROD rate to three times the standard deviation of that rate, and the limit of quantification (LOQ) was calculated by adding the average basal EROD rate to ten times the standard deviation of that rate. LODs ranged from 0.16 to $0.70 \mathrm{pmol} / \mathrm{min} / \mathrm{mg}$ whereas the LOQs ranged from 0.8 to $1.41 \mathrm{pmol} / \mathrm{min} / \mathrm{mg}$. The results of this QA program indicated that the results of the bioassay accurately reflected the hepatic EROD rates of the samples analyzed. 


\section{Fish Health Indicators}

\section{General Histopathological Analyses}

Tissues preserved in 10\% NBF (liver, kidney, spleen, gill, gonad, and grossly visible lesions) were shipped to the LSC (Leetown, West Virginia) and NOAA (Seattle, Washington) and prepared for routine histopathological analysis (Blazer and others, 2002). Tissue sections (6- $\mu \mathrm{m}$, on glass slides) were stained with hematoxylin and eosin (H \& E) for light microscopic examination.

\section{Quantitative Organism-Level Indicators}

The prevalence of gross external pathological disorders was determined with a rating of present (1) or not present (0) deduced from field data. Gross pathologies were selected for consistency with other monitoring programs that have used this type of assessment (Fournie and others, 1996). Gross abnormalities included grossly visible disorders of the eye (exopthalmia, hemorrhage, opacity, emboli, missing), opercles, (shortening, deformities, parasites), and body surface (ulcers, parasites, discolored areas or tumors). In addition, disorders of the fins and skeleton were included. Numerical values were assigned to internal and external observations of lesions recorded in the field, and a necropsy-based fish health assessment index (HAI) score was calculated for each fish by summing these values for all organs (Blazer and others, 2002). An index was computed for a fish only if there was a complete assessment.

Body and organ weights measured in the field were used to calculate condition and organosomatic indices. Condition factor was computed as body weight $(\mathrm{g}) / \mathrm{length}^{3}(\mathrm{~cm})$. The HSI was calculated as liver weight/(total body weight - gonad weight) X 100. Similarly, the SSI was calculated as spleen weight/(total body weight - gonad weight) X 100. The weight of the gonads was subtracted from the body weight in the computation of HSI and SSI to minimize the effect of the reproductive cycle on these indices (Dethloff and Schmitt, 2000). GSI was calculated as gonad weight/total body weight $\mathrm{X} 100$. Additional information on these indices is given by Blazer and others (2002) and Dethloff and Schmitt (2000).

\section{Macrophage Aggregates}

Macrophage aggregates and MA pigments in spleen sections were visualized through a staining procedure called the Perl's method (Luna, 1992). Using this method, melanin, a melanosome pigment derived from tyrosine metabolism, appears black; hemosiderin, a protein-bound iron pigment, appears blue; and ceroid/lipofuscin, lipogenic pigments arising from the oxidation of unsaturated lipids, appears yellow-tan.
All MA measurements were made with a computer-based image analysis system and included the number of aggregates in $2 \mathrm{~mm}^{2}$ of tissue (MA-\#) and the area of each aggregate (MA-size). The percentage of tissue occupied by MA (MA-\%) was computed from these measurements (Blazer and others, 2002).

\section{Reproductive Indicators}

\section{Gonadal Histopathology}

The posterior tip of the gonad was dissected in the field and fixed immediately in 10\% NBF. Transverse sections were processed for routine light microscopy (embedded in paraffin, sectioned at $6 \mu \mathrm{m}$, and stained with $\mathrm{H} \& \mathrm{E}$ ).

Female gonadal tissue was staged using developmental stages (designated 0-5) to classify each section (Blazer, 2002; McDonald and others, 2002; Nagahama, 1983; Rodriguez and others, 1995; Treasurer and Holliday, 1981). Fish ovaries typically contain oocytes in several developmental stages and were classified according to the maturity of the predominant stage of oogenesis of each tissue samples (Fig. 2). Ovaries containing only undeveloped, previtellogenic oocytes were assigned to stage 0 . Samples containing only previtellogenic chromatin nucleoli and perinuclear oocytes, identified by cytoplasm that stained basophilic with $\mathrm{H} \& \mathrm{E}$ were assigned to stage 1 . Ovaries containing previtellogenic oocytes as in stage 1 plus some cortical alveoli oocytes were classified as stage 2 (early vitellogenic). Those containing larger oocytes in which the cortical alveoli were pushed to the periphery of the cell, yolk globules filled the center, and the chorion of the developing oocytes were thicker than in earlier stages were designated as stage 3 (mid-vitellogenic). Ovaries containing oocytes with fused yolk globules were designated as stage 4 (late vitellogenic). Ovaries containing postovulatory follicles, which can be observed for some time after ovulation, are typically assigned to stage 5 (spent). After the ovarian tissues were staged they were further examined by light microscopy for atresia (Fig. 2) and other abnormalities. One hundred oocytes in each sampled were counted, when possible, and those showing morphological evidence of resorption or necrosis were quantified and the percent of atretic oocytes were calculated.

Analogous to the procedure used to stage ovaries, male gonadal tissue was classified into five developmental stages (0-4) according to the maturity of the predominant stage of spermatogenesis of each tissue sample (Fig. 3; Blazer, 2002; Nagahama, 1983). Immature, undeveloped, or regressed testes containing only spermatogonia were classified as stage 0 (immature) whereas those containing primarily spermatocytes and spermatids were designated as stage 1 (early spermatogenic). Stage-2 (mid-spermatogenic) testes contain approximately equal proportions of spermatocytes, spermatids, and spermatozoa, and testes containing primarily mature 

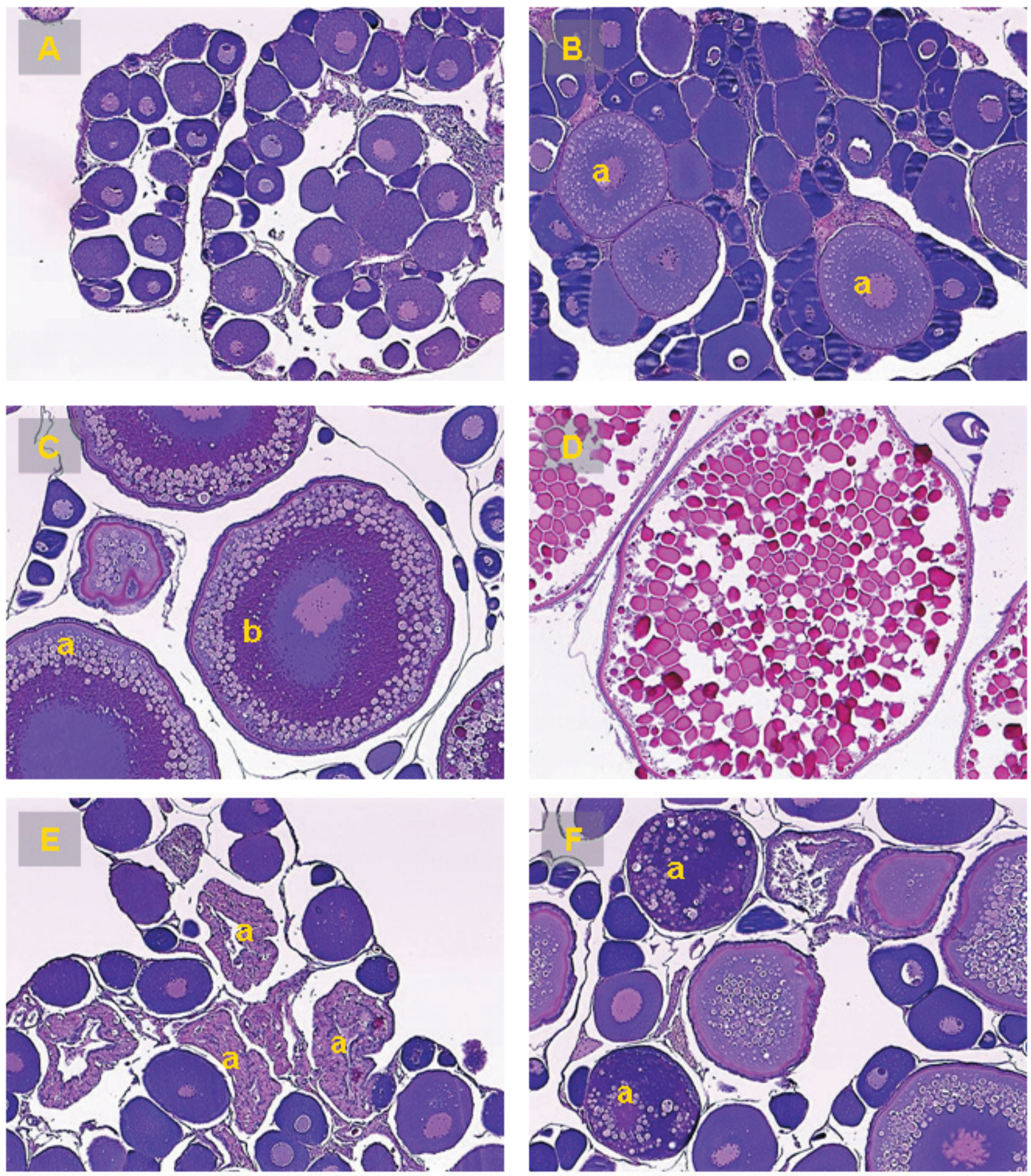

Figure 2. Gonadal stages and atresia in female fish ovaries. A. Stage-1 (immature) ovary containing previtellogenic oocytes. B. Stage-2 (early-vitellogenic) ovary containing oocytes with cortical alveoli (a). C. Stage-3 (mid-vitellogenic) ovary containing enlarged oocytes. Cortical alveoli (a) are migrating to periphery, and yolk globules (b) beginning to form. D. Stage-4 (late vitellogenic) ovary containing enlarged oocytes and condensed yolk globules. E. Stage-5 (spent) ovary containing postovulatory follicles (a) and previtellogenic oocytes. F. Atretic previtellogenic oocytes (a) where nucleus has begun to disintegrate, cytoplasm stains darker and abnormal cortical alveoli and yolk granules are present. H \& E stain (X165). 

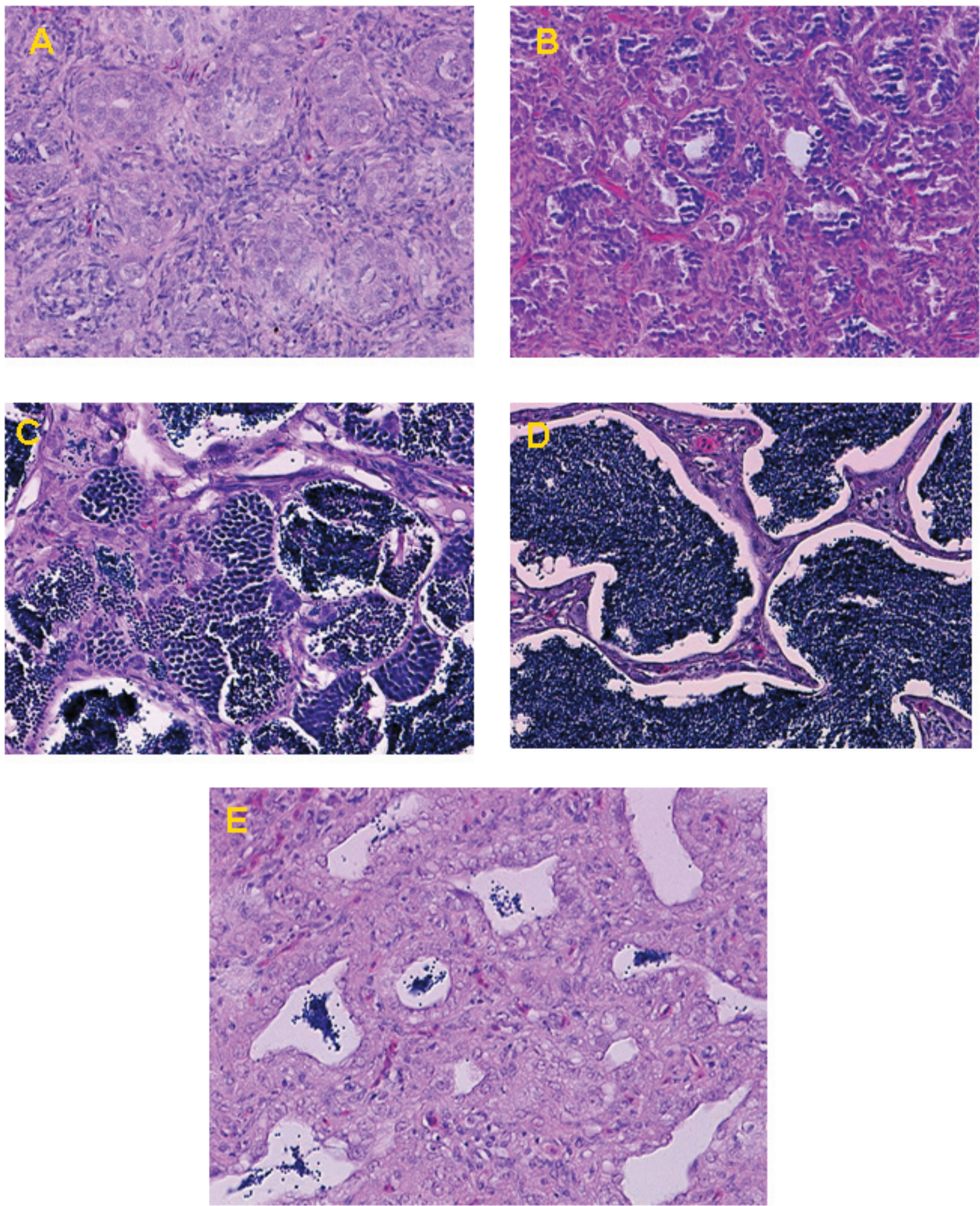

Figure 3. Gonadal stages in male fish testes. A. Stage-0 (immature) testes having primarily spermatogonia. B. Stage-1 (early spermatogenic) testes having spermatogonia and spermatocytes present. C. Stage-2 (mid-spermatogenic) testes with approximately equal numbers of spermatocytes, spermatids, and spermatozoa. D. Stage-3 (late spermatogenic) testes containing primarily mature sperm. E. Stage-4 (spent) testes having residual sperm present. H \& E stain (X412). 
spermatozoa were identified as stage 3 (late spermatogenic). Stage-4 testes are postspawning or spent. Testicular tissue was also examined microscopically for any abnormalities such as intersex and other abnormalities. Male fish were classified as intersex when individual or small foci of undeveloped oocytes were observed within testicular tissue (that is, when an ovotestis condition was detected).

\section{Vitellogenin}

Vitellogenin was purified from female northern pike and longnose sucker plasma samples using the BIOCAD purification system (Perseptive Biosystems) and anion exchange packing material (POROS 20HQ). Plasma was diluted 1:10 in 10 $\mathrm{mM}$ bis-tris-propane, $150 \mathrm{mM} \mathrm{NaCl}, \mathrm{pH} 9.0$ and then loaded onto the ion exchange column. Nonbinding proteins were eluted by several column volumes of the dilution buffer. Vitellogenin is specifically released using a linear gradient of $\mathrm{NaCl}$ (150-800 mM), and captured using a fraction collector. The vtg protein peak was identified by comparing male, female, and estrogenized male chromatographs. After purification, the protease inhibitor, Aprotinin $(10 \mathrm{KIU} / \mathrm{mL})$, glycerol $(50 \%$ $\mathrm{v} / \mathrm{v})$, and azide $(0.02 \% \mathrm{v} / \mathrm{v})$ were added. Total protein of $\mathrm{vtg}$ was determined by the Bradford assay using bovine albumin as a standard.

Purified vtg was screened for reactivity against a panel of anti-vtg monoclonal antibodies (Mabs) developed by the Biomarkers and Hybridoma Cores at the University of Florida/ Interdisciplinary Center for Biological Research (ICBR). Reactivity was determined by direct ELISA using purified vtg standards $(0,0.01,0.1,1.0 \mu \mathrm{g} / \mathrm{mL})$ and male plasma. Mabs developed against carp (1C8, HL 1364) and white sucker (Catostomus commersoni; 2C11, HL 1689) vtg, reacted quantitatively to the vtg of northern pike and longnose sucker, respectively. Moreover, these antibodies did not recognize male plasma proteins.

Plasma vtg concentrations were determined by direct ELISA using monoclonal antibodies, 1C8 (HL 1364) for northern pike and 2C11 (HL 1689) for longnose sucker. The plasma samples were diluted 1:200, 1:10,000, 1:100,000 and 1:1,000,000 with $10 \mathrm{mM}$ phosphate, $150 \mathrm{mM} \mathrm{NaCl}, 0.02 \%$ azide, $10 \mathrm{KIU} / \mathrm{mL}$ Aprotinin, pH 7.6 (PBSZ-AP). Vitellogenin standards containing 1:200, $10 \mathrm{k}, 100 \mathrm{k}$, and $1000 \mathrm{k}$ male plasma (in PBSZ-AP) were added to account for matrix effect (Denslow and others, 1999). Samples and standards were loaded onto a 96-well ELISA plate (NUNC) in triplicate and stored overnight at $4^{\circ} \mathrm{C}$ in a humidified container. The following day the plates were washed four times with PBSZ and then blocked with $1 \%$ BSA in $10 \mathrm{mM}$ tris, $150 \mathrm{mM} \mathrm{NaCl}$, $0.05 \%$ tween, $0.02 \%$ azide, $10 \mathrm{KIU} / \mathrm{mL}$ Aprotinin, $\mathrm{pH} 7.6(1 \%$ BSA /TBSTZ-AP) for $2 \mathrm{~h}$ at room temperature. The plates were rewashed with PBSZ (four times) and the monoclonal and loaded to each plate. The lowest dilution (1:200) was probed with $3 \mu \mathrm{g} / \mathrm{mL}$ of the Mab and dilutions of $\geq 10,000$ with $1.0 \mu \mathrm{g} / \mathrm{mL}$. After the addition of the Mab, plates were stored at $4^{\circ} \mathrm{C}$ overnight in a humidified container. The following day the plates were washed and the biotinylated secondary antibody (goat antimouse IgG-biotin) was added to each well at 1:1000 dilution in 1\% BSA/TBSTZ-AP and incubated at room temperature for $2 \mathrm{~h}$. The plates were washed, and strepavidin-alkaline phosphatase was added at 1:1000 dilution in $1 \% \mathrm{BSA} / \mathrm{TBSTZ}$-AP and incubated for $2 \mathrm{~h}$ at room temperature. After washing the plates for the final time, the color was developed by adding $1 \mathrm{mg} / \mathrm{mL}$ p-nitro-phenyl phosphate in carbonate buffer (0.03 $\mathrm{M}$ carbonate, $\left.2 \mathrm{mM} \mathrm{MgCl}_{2}, \mathrm{pH} 9.6\right)$ and measuring the color using an ELISA plate reader (SpectraMax Plus384) at $405 \mathrm{~nm}$. Curve fitting and data analysis were determined using SoftMaxProTM ELISA software (Molecular Devices).

ELISA sensitivity or LOD was $0.001 \mathrm{mg} / \mathrm{mL}$ for both species. The coefficient of variation $(\mathrm{CV})$ of triplicate values and correlation coefficient were maintained at $\leq 10 \%$ and $\geq$ $95 \%$, respectively, to maintain ELISA accuracy. The outlier was removed if the CV triplicates were $>10 \%$, and the sample was run again. Inter- and intra-assay variation of this type of ELISA are typically, $\leq 10 \%$ and $\leq 5 \%$, respectively.

\section{Steroid Hormones}

Concentrations of estradiol (E2) and 11-ketotestosterone (KT) in plasma samples collected from northern pike and longnose sucker were measured by radioimmunoassay (RIA). For analysis, samples were thawed and split. Duplicate plasma samples $(50 \mu \mathrm{L})$ were extracted twice by adding $4 \mathrm{~mL}$ of ethyl ether, vortexing for $1 \mathrm{~min}$, freezing the aqueous layer in a methanol-dry ice bath, and decanting the ether layer containing the lipophilic sex steroids. Standard curves were prepared in phosphate-buffered saline with gelatin and azide (PBSGA) buffer using variable amounts of unlabeled E2 or KT $(1,5,10,25,50,100,250,500$ and 1000 pg) and a constant concentration of radiolabeled hormone. Cross-reactivities of the E2 antiserum were examined against other steroids, including estrone, estriol, $17 \alpha$-estradiol, and androstenedione and were found to be at acceptable levels. Cross-reactivities of the KT antiserum were examined against other steroids, including testosterone, dihydrotestosterone, and androstenedione and were also found to be at acceptable levels. Reaction comprised plasma extract $(50 \mu \mathrm{L})$, radiolabeled sex steroid hormone $(100 \mu \mathrm{L})$, and corresponding sex steroid hormonespecific antibody $(100 \mu \mathrm{L})$ in PBSGA buffer $(250 \mu \mathrm{L})$. The reaction solutions were allowed to equilibrate overnight, during which time the unlabeled hormone from the extract and a constant concentration of the corresponding radiolabeled sex steroid hormone competed for the same antibody binding sites. Following incubation, nonantibody-bound radiolabeled hormone was removed by adding $250 \mu \mathrm{L}$ of charcoal dextran and centrifuging at $3000 \mathrm{X}$ g for $10 \mathrm{~min}$. Supernatant aliquots $(0.4$ $\mathrm{mL}$ ), containing bound radiolabeled hormone, were carefully removed, so as not to disturb the charcoal pellet, and placed in a vial with $4 \mathrm{~mL}$ of scintillation fluid. Radioactivity was 
measured using scintillation spectrophotometry. Sex steroid concentrations in plasma extracts were determined using a four-parameter logistics regression analysis of standard curves, which was then used to calculate concentrations for plasma extracts.

Hormone concentrations in plasma samples from northern pike and longnose sucker were corrected for extraction efficiency of $94 \pm 3.4 \%$ for E2 and $89 \pm 4.1 \%$ for KT. The minimum concentration distinguishable from zero was $7.4 \mathrm{pg} /$ $\mathrm{mL}$ for E2 and $9.7 \mathrm{pg} / \mathrm{mL}$ for KT. Pooled samples in triplicate were assayed serially in 10-, 20-, 30-, 40-, and 50- $\mu \mathrm{L}$ volumes (final volume of $50 \mu \mathrm{L}$ with charcoal-stripped plasma). The resulting inhibition curves were parallel to the respective standard curve; the tests for homogeneity of regression indicated that the curves did not differ. Further characterization of the assays involved measurement of known amounts (1, 2, 5, 10, $25,50,100,250$, and $500 \mathrm{pg}$ ) of E2 or KT in $50 \mu \mathrm{L}$ charcoalstripped plasma. Inter- and intra-assay coefficients of variation were $8.3 \%$ and $9.5 \%$, respectively, for E2 and $7.4 \%$ and $8.9 \%$, respectively, for $\mathrm{KT}$.

The ratio of $\mathrm{E} 2$ to $\mathrm{KT}$ (E/KT) is an additional variable used to analyze sex steroids (Folmar and others, 1996; Hileman, 1994). Typically, female fish will have an E/KT ratio greater than 1.0, and male fish will have an E/KT ratio below 1.0, although exact ranges of normality and seasonal fluctuations in this variable have not been established.

\section{Data Set Composition and Statistical Analyses}

For indicators based on individual fish (that is, biomarkers and demographic endpoints), data were discussed in terms of the magnitudes of the means or medians for combined stages or each stage within a gender for different species. Data were summarized graphically with box plots presenting the mean, median, range, and 25 th and 75 th percentiles. Some biomarkers were also analyzed more rigorously (see following sections).

Descriptive statistics were calculated for length, weight, and age data for species at individual stations. Fish for which no otoliths or only regenerated scales were collected (17 fish: 16 northern pike; 1 longnose sucker) were not included in the presentation or analysis of age data. Fish for which the field gender identification could not be verified histologically (1 northern pike and 1 longnose sucker) were reported as NG (no gonad). Data for northern pike, longnose sucker, and burbot are presented in tabular form and are discussed. Length and weights of northern pike were also analyzed statistically because of the influence of fish size on concentrations of $\mathrm{Hg}$ in predatory fish (see next section). Length and weight data for all other species are presented only in tabular form.

A total of 31 composite samples from 10 stations were analyzed for chemical contaminants in fish tissue. Nineteen samples $(61 \%)$ from 10 stations were northern pike, nine samples (29\%) from 5 stations were longnose sucker, and three samples (10\%) from two stations were burbot. All results for composite samples were converted to, analyzed statistically as, and reported as ww concentrations. A value of one-half the LOD was substituted for censored values (that is, values $<$ LOD) in the computation of un-weighted geometric station means and for statistical analyses and were substituted for censored values in all graphs (Schmitt and others, 1999b). Concentrations of many contaminants in 2002 YRB composite samples were $<\mathrm{LOD}$, which precluded rigorous statistical analysis. Data for composite samples (tissue concentrations) are presented graphically and as tabular summaries. Geographic differences for $\mathrm{Hg}$ and Se were also examined statistically using analysis of variance (ANOVA). Log-transformed concentrations of these analytes in northern pike and longnose sucker were analyzed with series of $t$-tests using a pooled error mean-square (MS $)$ representing differences between or among samples of the same species from the same station. A nominal $\alpha$-level of 0.01 was used in these comparisons to protect against experiment-wise error. Because concentrations of $\mathrm{Hg}$ in predatory fish increase with size, age, or both (for example, Wiener and others, 2002), log-transformed lengthadjusted $(\mathrm{HgL})$ and weight-adjusted $(\mathrm{HgW})$ concentrations were also tested using this procedure. Following the method of Brumbaugh and others (2001), the adjusted $\mathrm{Hg}$ values were computed by dividing the measured concentration in each composite sample by the mean length $(\mathrm{m})$ and weight $(\mathrm{kg})$ of the individual fish comprised by the sample. Length, weight, $\mathrm{Hg}, \mathrm{HgW}$, and $\mathrm{HgL}$ were also analyzed separately for northern pike using the one-way analysis, which resulted in a more conservative test with fewer degrees of freedom and $\mathrm{MS}_{\mathrm{e}}$-values based on only one species. Chemical concentration data from other studies were compared to 2002 concentrations in the current report by converting dw concentrations to ww concentrations, assuming $75 \%$ moisture if the original study reported concentrations in dw and percent moisture was not reported.

Many biomarkers differ among species, gender, and reproductive stages (Schmitt, 2002a; Schmitt and Dethloff, 2000). Accordingly, a series of linear ANOVA models were fit to the individual fish data for longnose sucker and northern pike to determine which factors influenced biomarker responses in these taxa, using the analyses conducted on larger previous BEST LRMN data set as a guide (Schmitt, 2002a). The results of these analyses were reported as $F$-values and significance levels and were used to guide the graphical presentation and discussion of the findings; however, because of the complexity of the models and the small size of the data set, the means could not be adjusted for the factors in the models. Data are presented and discussed in terms of the magnitudes of the means or medians for combined genders or each gender within a species and at different stations within a species. Some individual points are also discussed. Data are presented graphically and summarized as described for the demographic data. 


\section{Results and Discussion}

\section{Geographic Distribution and Demographic Characteristics of the Fish Collected}

A total of 217 fish representing three species were collected from 10 YRB stations in 2002 (Table 5). Northern pike and longnose sucker accounted for $94 \%$ of the fish collected. Northern pike $(n=158)$ were collected at 10 stations, longnose sucker $(n=46)$ were collected at 5 stations, and burbot $(n=13)$ were collected at 2 stations. Reasonable sample sizes $(n>5)$ were obtained from seven stations for northern pike (Stations $302,303,306,307,308,309$, and 310) and three stations for longnose sucker (Stations 301, 305, and 308) (Table 5).

Total length, weight, and age were examined in northern pike from the YRB. The mean total length (TL) of northern pike was $601 \mathrm{~mm}$ (range 373-1,085 mm) and mean weight was 1,462 $\mathrm{g}$ (range 280-8,000 g) (Table 6). The mean age for all northern pike collected was $5.8 \mathrm{y}$ (range 1-17 y). In general, female northern pike had a greater mass ( $623 \mathrm{~g}$ vs. $574 \mathrm{~g}$ ) and were longer $(1,643 \mathrm{~mm}$ vs. $1,246 \mathrm{~mm})$ than male northern pike, but females were slightly younger ( $5.8 \mathrm{y}$ vs. $5.9 \mathrm{y}$ ) than males. Male and female northern pike were generally smallest (mean TL and weight) at Station 303 (Table 6) and largest at Stations 306 and 307. Mean age for females and males was lowest at Station 303 and highest at Station 309 for females and Station 307 for males. Mean age was not consistently related to mean size; that is, the oldest northern pike were not necessarily the largest, which indicates that growth rates vary among stations (Table 6).

Total length, weight, and age were similar in longnose sucker sampled throughout the YRB. The mean TL and mass of longnose sucker from the YRB was $433 \mathrm{~mm}$ (range $358-509 \mathrm{~mm}$ ) and $674 \mathrm{~g}$ (range 350-1,250 g), respectively (Table 7). The mean age for longnose sucker was $2.9 \mathrm{y}$ (range 1-5). Female longnose sucker had a greater mass (449 g vs. $399 \mathrm{~g}$ ) and were longer (755 $\mathrm{mm}$ vs. $508 \mathrm{~mm}$ ) than male longnose sucker, but the mean age for both female and male

Table 5. Number of fish collected, organized by species, station, and gender, in the Yukon River Basin in 2002. Stations are listed upstream to downstream. Station numbers are given in parentheses. Species totals that include individual(s) of unknown gender are designated by an asterisk (*).

\begin{tabular}{|c|c|c|c|c|}
\hline Station and Species & Male & Female & $\begin{array}{c}\text { Species } \\
\text { Total }\end{array}$ & $\begin{array}{c}\text { Station } \\
\text { Total }\end{array}$ \\
\hline Charley-Kandik, AK (301) & & & & 18 \\
\hline Northern pike & 2 & 4 & 6 & \\
\hline Longnose sucker & 1 & 11 & 12 & \\
\hline Fish Hook Bend, AK (302) & & & & 20 \\
\hline Northern pike & 5 & 15 & 20 & \\
\hline Fort Yukon, AK (303) & & & & 22 \\
\hline Northern pike & 11 & 11 & 22 & \\
\hline The Bridge, AK (304) & & & & 11 \\
\hline Northern pike & 2 & 7 & 9 & \\
\hline Longnose sucker & 0 & 2 & 2 & \\
\hline Fairbanks, AK (305) & & & & 36 \\
\hline Northern pike & 0 & 3 & 3 & \\
\hline Longnose sucker & 11 & 9 & $21^{*}$ & \\
\hline Burbot & 4 & 8 & 12 & \\
\hline Tolovana, AK (306) & & & & 23 \\
\hline Northern pike & 10 & 10 & 20 & \\
\hline Longnose sucker & 1 & 2 & 3 & \\
\hline Tanana, AK (307) & & & & 20 \\
\hline Northern pike & 8 & 12 & 20 & \\
\hline Galena, AK (308) & & & & 28 \\
\hline Northern pike & 12 & 8 & 20 & \\
\hline Longnose sucker & 1 & 7 & 8 & \\
\hline Innoko, AK (309) & & & & 21 \\
\hline Northern pike & 11 & 9 & $21^{*}$ & \\
\hline Kotlik, AK (310) & & & & 18 \\
\hline Northern pike & 8 & 9 & 17 & \\
\hline Burbot & 1 & 0 & 1 & \\
\hline
\end{tabular}


Table 6. Lengths, weights, and ages of northern pike (Esox lucius) collected in the Yukon River Basin in 2002. Stations are listed upstream to downstream. Station numbers are given in parentheses. Sample size $(n)$, arithmetic mean, standard deviation (SD), and range are also given. Fish for which gender could not be determined are identified as having no gonad (NG).

\begin{tabular}{|c|c|c|c|c|c|c|c|c|c|c|c|c|c|}
\hline \multirow{2}{*}{ Location } & \multirow{2}{*}{ Gender } & \multicolumn{4}{|c|}{ Length (mm) } & \multicolumn{4}{|c|}{ Weight (g) } & \multicolumn{4}{|c|}{ Age (years) } \\
\hline & & $n$ & Mean & SD & Range & $n$ & Mean & SD & Range & $n$ & Mean & SD & Range \\
\hline \multirow[t]{4}{*}{ Entire Basin } & All & 157 & 601 & 120 & $373-1085$ & 158 & 1462 & 1125 & $280-8000$ & 142 & 5.8 & 2.9 & $1-17$ \\
\hline & $\mathrm{F}$ & 88 & 623 & 135 & $373-1085$ & 88 & 1643 & 1347 & $280-8000$ & 77 & 5.8 & 2.8 & $2-17$ \\
\hline & M & 68 & 574 & 89 & $407-849$ & 69 & 1246 & 702 & $310-3900$ & 64 & 5.9 & 3.1 & $1-15$ \\
\hline & NG & 1 & 431 & -- & -- & 1 & 430 & -- & -- & 1 & 4 & -- & -- \\
\hline Charley- & $\mathrm{F}$ & 4 & 639 & 79 & $538-729$ & 4 & 1553 & 561 & $852-2022$ & 4 & 5.8 & 1.0 & $5-7$ \\
\hline $\begin{array}{l}\text { Kandik, AK } \\
(301)\end{array}$ & M & 2 & 654 & 35 & $629-678$ & 2 & 1568 & 286 & $1366-1770$ & 2 & 8.5 & 2.1 & $7-10$ \\
\hline Fish Hook & $\mathrm{F}$ & 15 & 608 & 80 & $460-757$ & 15 & 1295 & 516 & $600-2600$ & 13 & 5.8 & 1.9 & $2-9$ \\
\hline $\begin{array}{l}\text { Bend, AK } \\
(302)\end{array}$ & M & 5 & 591 & 46 & $545-652$ & 5 & 1162 & 355 & $800-1600$ & 4 & 6.0 & 0.8 & $5-7$ \\
\hline Fort Yukon & $\mathrm{F}$ & 11 & 537 & 83 & $374-654$ & 11 & 829 & 319 & $280-1270$ & 8 & 4.5 & 1.9 & $2-7$ \\
\hline AK (303) & M & 11 & 498 & 50 & $407-576$ & 11 & 646 & 201 & $310-990$ & 9 & 4.2 & 1.5 & $2-6$ \\
\hline \multirow{2}{*}{$\begin{array}{l}\text { The Bridge, } \\
\text { AK (304) }\end{array}$} & $\mathrm{F}$ & 7 & 725 & 250 & $415-1070$ & 7 & 2923 & 2794 & $390-8000$ & 6 & 7.0 & 2.8 & $3-10$ \\
\hline & M & 2 & 579 & 141 & $479-678$ & 2 & 1200 & 877 & $580-1820$ & 2 & 6.0 & 4.2 & $3-9$ \\
\hline \multirow{2}{*}{$\begin{array}{l}\text { Fairbanks, } \\
\text { AK (305) }\end{array}$} & $\mathrm{F}$ & 3 & 615 & 74 & $568-700$ & 3 & 1440 & 859 & $850-2426$ & 3 & 5 & 1.7 & $4-7$ \\
\hline & M & 0 & -- & -- & -- & 0 & -- & -- & -- & 0 & -- & -- & -- \\
\hline \multirow{2}{*}{$\begin{array}{l}\text { Tolovana, } \\
\text { AK (306) }\end{array}$} & $\mathrm{F}$ & 10 & 661 & 158 & $545-1085$ & 10 & 2061 & 2078 & $950-7820$ & 8 & 6.3 & 4.9 & $2-17$ \\
\hline & M & 10 & 609 & 99 & $450-720$ & 10 & 1479 & 692 & $565-2460$ & 10 & 5.7 & 4.1 & $1-12$ \\
\hline \multirow{2}{*}{$\begin{array}{l}\text { Tanana, AK } \\
(307)\end{array}$} & $\mathrm{F}$ & 12 & 615 & 148 & $373-865$ & 12 & 1704 & 1001 & $300-3900$ & 12 & 6.3 & 3.0 & $2-12$ \\
\hline & M & 8 & 642 & 144 & $429-849$ & 8 & 2069 & 1298 & $550-3900$ & 8 & 8.9 & 4.3 & $3-15$ \\
\hline \multirow{2}{*}{$\begin{array}{l}\text { Galena, AK } \\
(308)\end{array}$} & $\mathrm{F}$ & 8 & 629 & 66 & $551-772$ & 8 & 1525 & 452 & $950-2100$ & 7 & 4.9 & 1.6 & $3-8$ \\
\hline & M & 12 & 591 & 42 & $490-653$ & 12 & 1325 & 256 & $800-1750$ & 12 & 4.9 & 1.6 & $3-8$ \\
\hline \multirow{3}{*}{$\begin{array}{l}\text { Innoko, AK } \\
(309)\end{array}$} & $\mathrm{F}$ & 9 & 665 & 188 & $426-866$ & 9 & 2163 & 1716 & $355-4658$ & 8 & 7.5 & 2.9 & $3-11$ \\
\hline & $\mathrm{M}$ & 10 & 521 & 76 & $442-650$ & 11 & 945 & 553 & $430-1870$ & 10 & 6.7 & 2.9 & $4-13$ \\
\hline & NG & 1 & 431 & -- & -- & 1 & 430 & -- & -- & 1 & 4.0 & -- & -- \\
\hline \multirow{2}{*}{$\begin{array}{l}\text { Kotlik, AK } \\
(310)\end{array}$} & $\mathrm{F}$ & 9 & 588 & 67 & $529-752$ & 9 & 1372 & 348 & $950-3030$ & 8 & 4.6 & 2.7 & $2-11$ \\
\hline & M & 8 & 581 & 54 & $522-674$ & 8 & 1236 & 306 & $880-1810$ & 7 & 4.6 & 2.2 & $2-8$ \\
\hline
\end{tabular}

longnose sucker was similar (2.9 y vs. 2.7 y). Mean size (TL and weight) and age of longnose sucker were similar among stations (Table 7). Overall, the average lengths and weights of longnose sucker from the YRB were similar but were younger than those collected from the CRB in 1997 (Hinck and others, 2004).

Burbot were collected from Stations 305 and 310.

Female burbot outweighed male burbot (700 g vs. $589 \mathrm{~g}$ ), were longer (2,387 mm vs. 1,100 mm), and were older (10.6 y vs. 9.5 y) at Station 305 (Table 7). Only one male burbot was collected from Station 310.

Fish collected from the YRB were relatively consistent among stations with respect to species, size, and age. Differences were noted among stations means for measured morphologic and demographic parameters of each species. Fish size and age varied more at some stations than at others, although consistent patterns were not reflected in multiple species from a station. Few relatively large or small individual fish contributed to this variation, and some degree of variation among stations was expected because sample sizes varied. 
Table 7. Lengths, weights, and ages of longnose sucker (Catostomus catostomus) and burbot (Lota lota) collected in the Yukon River Basin in 2002. Stations are listed upstream to downstream. Station numbers are given in parentheses. Sample size $(n)$, arithmetic mean, standard deviation (SD), and range are also given. Fish for which gender could not be determined are identified as having no gonad (NG).

\begin{tabular}{|c|c|c|c|c|c|c|c|c|c|c|c|c|c|}
\hline \multirow{2}{*}{ Location } & \multirow{2}{*}{ Gender } & \multicolumn{4}{|c|}{ Length (mm) } & \multicolumn{4}{|c|}{ Weight (g) } & \multicolumn{4}{|c|}{ Age (years) } \\
\hline & & $n$ & Mean & SD & Range & $n$ & Mean & SD & Range & $n$ & Mean & SD & Range \\
\hline \multicolumn{14}{|c|}{ Longnose sucker } \\
\hline \multirow[t]{4}{*}{ Entire Basin } & All & 46 & 433 & 40 & $358-509$ & 46 & 674 & 204 & $350-1250$ & 45 & 2.9 & 0.8 & $1-5$ \\
\hline & $\mathrm{F}$ & 31 & 449 & 37 & $366-509$ & 31 & 755 & 196 & $405-1250$ & 31 & 2.9 & 0.9 & $1-5$ \\
\hline & $\mathrm{M}$ & 14 & 399 & 22 & $358-435$ & 14 & 508 & 85 & $350-700$ & 13 & 2.7 & 0.5 & $2-3$ \\
\hline & $\mathrm{NG}$ & 1 & 400 & -- & -- & 1 & 485 & -- & -- & 1 & 4.0 & -- & -- \\
\hline Charley- & $\mathrm{F}$ & 11 & 456 & 25 & $424-491$ & 11 & 738 & 135 & $527-946$ & 11 & 3.4 & 0.5 & $3-4$ \\
\hline $\begin{array}{l}\text { Kandik, AK } \\
(301)\end{array}$ & M & 1 & 435 & -- & -- & 1 & 540 & -- & -- & 1 & 3.0 & -- & -- \\
\hline \multirow{2}{*}{$\begin{array}{l}\text { The Bridge, } \\
\text { AK (304) }\end{array}$} & $\mathrm{F}$ & 2 & 474 & 50 & $439-509$ & 2 & 930 & 269 & $740-1120$ & 2 & 3.5 & 0.7 & $3-4$ \\
\hline & M & 0 & -- & -- & -- & 0 & -- & -- & -- & 0 & -- & -- & -- \\
\hline \multirow{3}{*}{$\begin{array}{l}\text { Fairbanks, } \\
\text { AK (305) }\end{array}$} & $\mathrm{F}$ & 9 & 434 & 44 & $366-476$ & 9 & 672 & 192 & $405-985$ & 9 & 2.4 & 0.5 & $2-3$ \\
\hline & $\mathrm{M}$ & 11 & 395 & 21 & $358-419$ & 11 & 488 & 72 & $350-570$ & 10 & 2.7 & 0.5 & $2-3$ \\
\hline & $\mathrm{NG}$ & 1 & 400 & -- & -- & 1 & 485 & -- & -- & 1 & 4.0 & -- & -- \\
\hline \multirow{2}{*}{$\begin{array}{l}\text { Tolovana, } \\
\text { AK (306) }\end{array}$} & $\mathrm{F}$ & 2 & 425 & 64 & $379-470$ & 2 & 550 & 141 & $450-650$ & 2 & 4.0 & 1.4 & $3-5$ \\
\hline & M & 1 & 394 & -- & -- & 1 & 500 & -- & -- & 1 & 3.0 & -- & -- \\
\hline \multirow{2}{*}{$\begin{array}{l}\text { Galena, AK } \\
(308)\end{array}$} & $\mathrm{F}$ & 7 & 457 & 34 & $399-496$ & 7 & 900 & 192 & $700-1250$ & 7 & 2.4 & 1.0 & $1-4$ \\
\hline & M & 1 & 415 & -- & -- & 1 & 700 & -- & -- & 1 & 2.0 & -- & -- \\
\hline \multirow{3}{*}{$\begin{array}{l}\text { Burbot } \\
\text { Fairbanks, } \\
\text { AK (305) }\end{array}$} & & & & & & & & & & & & & \\
\hline & $\mathrm{F}$ & 8 & 700 & 176 & $456-944$ & 8 & 2387 & 1893 & $515-6312$ & 8 & 10.6 & 3.1 & $5-14$ \\
\hline & M & 4 & 589 & 129 & $496-755$ & 4 & 1100 & 600 & $715-1988$ & 4 & 9.5 & 4.2 & $5-14$ \\
\hline \multirow{2}{*}{$\begin{array}{l}\text { Kotlik, AK } \\
(310)\end{array}$} & $\mathrm{F}$ & 0 & -- & -- & -- & 0 & -- & -- & -- & 0 & -- & -- & -- \\
\hline & $\mathrm{M}$ & 1 & 565 & -- & -- & 1 & 1080 & -- & -- & 1 & 7 & -- & -- \\
\hline
\end{tabular}

\section{Accumulative contaminants, H4IIE Bioassay, and EROD Activity}

\section{Elemental Contaminants}

\section{Arsenic}

Arsenic was detected in all 31 composite samples at concentrations ranging from 0.03 to $1.95 \mu \mathrm{g} / \mathrm{g} \mathrm{ww}$, with the maximum concentrations measured in male burbot from Station 310 (Fig. 4; Table 8). All other concentrations of As were $<1.08 \mu \mathrm{g} / \mathrm{g}$ ww with burbot samples having the three of the four greatest concentrations ( $>0.45 \mu \mathrm{g} / \mathrm{g}$ ww) (Fig. 4). The greatest geometric station mean for As was in fish samples from Station 304 (0.44 $\mu \mathrm{g} / \mathrm{g} \mathrm{ww})$ (Table 9).

Concentrations of As from the YRB in 2002 were compared to previous studies in the basin. Fish composite concentrations from the NCBP station located near Station
305 (Fairbanks) did not exceed $0.4 \mu \mathrm{g} / \mathrm{g}$ ww of As from 1972 to 1986 (Schmitt and others, 1999b); however, concentrations of As $>0.4 \mu \mathrm{g} / \mathrm{g}$ ww were detected in burbot from Station 305 in 2002. Most northern pike and longnose sucker collected throughout the YRB had concentrations of As $(0.2 \mu \mathrm{g} / \mathrm{g} \mathrm{ww})$ similar to those found at the NCBP site from 1980 to 1986. A single northern pike from the MRB near Garrison Dam, North Dakota had a concentration of As $<0.16 \mu \mathrm{g} / \mathrm{g}$ ww (Schmitt and others, 2002a). Northern pike collected near Alamosa, Colorado in the RGB had concentrations $<0.11 \mu \mathrm{g} / \mathrm{g}$ ww (Schmitt and others, 2004). Other studies measuring whole body concentrations of As in northern pike, longnose sucker, or burbot from the YRB were not found. Arsenic was not detected in northern pike muscle samples from the Koyukuk and Innoko NWRs in 1988 (Snyder-Conn and others, 1992). Mueller and Matz (2002) reported concentrations of As ranging from 0.02 to $0.23 \mu \mathrm{g} / \mathrm{g}$ ww in northern pike muscle samples collected from the Innoko NWR in the YRB in 1996-1997. Ecosystem and hydrologic differences among stations may partly explain the varying concentrations in burbot compared to northern pike and longnose sucker from the YRB. Deschu (1985) 


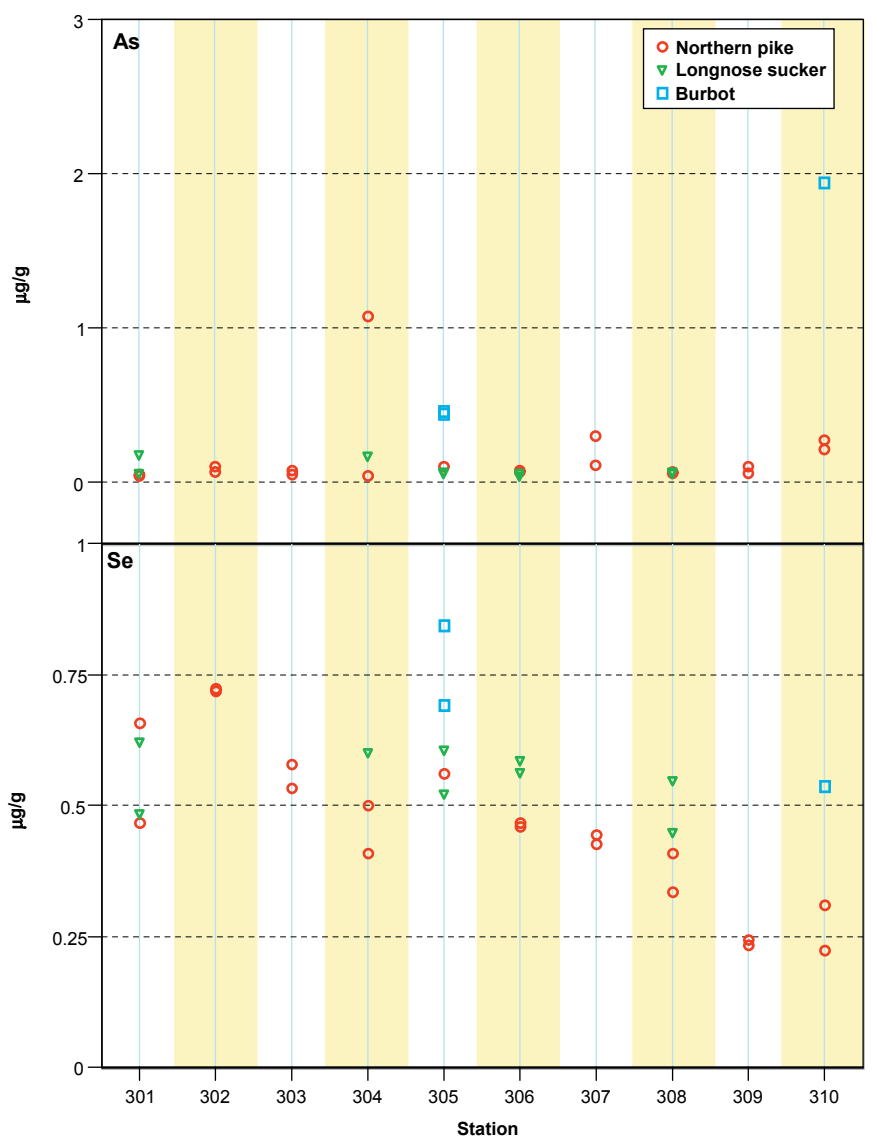

Figure 4. Concentrations ( $\mu \mathrm{g} / \mathrm{g} \mathrm{ww}$ ) of arsenic (As) and selenium (Se) by station and species in whole body fish composite samples collected in the Yukon River Basin in 2002. Censored values are plotted as one-half the LOD. Stations are ordered upstream to downstream. See Table 1 for station descriptions.

determined background concentrations of As to range from 0.2 to $0.5 \mu \mathrm{g} / \mathrm{g}$ ww in resident fish in Kantishna Hills, located in Denali National Park, south of the YRB.

Concentrations of As in northern pike, longnose sucker, and burbot were compared to those from wildlife criteria and laboratory toxicity tests. The concentrations of As detected in fish collected from the YRB in $2002(0.03-1.95 \mu \mathrm{g} / \mathrm{g} \mathrm{ww})$ are not considered a hazard to the fish or to piscivorous fishes or wildlife (USEPA, 1984). Jarvinen and Ankley (1999) reviewed several laboratory studies in which effects of As were evaluated relative to whole body concentrations in fish. Concentrations of 8.1-13.5 $\mu \mathrm{g} / \mathrm{g}$ ww were associated with loss of equilibrium and $5.4 \mu \mathrm{g} / \mathrm{g}$ ww caused increased mortality in rainbow trout ( $O$. mykiss) fingerlings (McGreachy and Dixon, 1990; 1992). Adult bluegill experienced reduced survival and growth at $11.6 \mu \mathrm{g} / \mathrm{g} \mathrm{ww}$ (Gilderhus, 1966). Concentrations in all fish from the YRB were less than these effect levels.

\section{Selenium}

Selenium was detected in all composite samples $(>0.2$ $\mu \mathrm{g} / \mathrm{g} \mathrm{ww}$ ), with the maximum concentration measured in male burbot from Station 305 (Fig. 4; Table 8). Selenium concentrations ranged from 0.23 to $0.85 \mu \mathrm{g} / \mathrm{g}$ ww with concentrations $\geq 0.6 \mu \mathrm{g} / \mathrm{g}$ ww in samples from Stations 301, 302, 304, and 305 (Fig. 4). Concentrations of Se did not reflect a pattern among species; northern pike, longnose sucker, and burbot all had concentrations $\geq 0.6 \mu \mathrm{g} / \mathrm{g}$ ww (Fig. 4). The geometric mean for Se was greatest in fish at Station $302(0.72 \mu \mathrm{g} / \mathrm{g} \mathrm{ww})$ and lowest in fish at Stations 309 and 310 (Table 9). Amongstation differences for concentrations of Se were significant in northern pike but not in longnose sucker or burbot (Table 10). Concentrations of Se in northern pike were significantly lower at Stations 309 and 310 compared to other YRB stations (Table 10; Fig. 4). Northern pike from Station 302 had concentrations of Se significantly greater than most stations, resulting in a decreasing Se trend upstream to downstream in the YRB.

BEST 2002 Yukon concentrations were compared to historical data from the YRB. Concentrations of Se from Station 305 were greater than NCBP concentrations near Fairbanks, which ranged from 0.30 to $0.58 \mu \mathrm{g} / \mathrm{g}$ ww for northern pike, longnose sucker, and burbot from 1972 to 1986 (Schmitt and others, 1999b). Whole body concentrations of Se in northern pike were measured in the MRB near Garrison Dam, North Dakota (0.49 $\mu \mathrm{g} / \mathrm{g}$ ww; $n=1)$ in 1995 (Schmitt and others, 2002a) and RGB near Alamosa, Colorado (0.17$0.69 ; n=4)$ in 1997 (Schmitt and others, 2004). Other studies measuring whole body concentrations of Se in these species in the YRB were not found. The USFWS has sampled fish from multiple NWRs in the YRB. Concentrations of Se were measured in northern pike muscle samples from the Koyukuk NWR (0.11-0.48 $\mu \mathrm{g} / \mathrm{g} \mathrm{ww})$ and Innoko NWR $(<0.11-0.21$ $\mu \mathrm{g} / \mathrm{g}$ ww) in 1988 (Snyder-Conn and others, 1992). Concentrations of Se ranged from 0.14 to $0.44 \mu \mathrm{g} / \mathrm{g}$ ww in northern pike muscle samples from the Koyukuk, Innoko, and Nowitna NWRs in 1991 (Mueller and others, 1996). Northern pike muscle samples from the Innoko NWR had concentrations of Se ranging from 0.15 to $0.48 \mu \mathrm{g} / \mathrm{g}$ ww in 1996-1997 (Mueller and Matz, 2002). The NCP determined that northern pike muscle samples from the Yukon Territory within the YRB had concentrations of Se of 0.4-0.7 $\mu \mathrm{g} / \mathrm{g}$ ww from 1996 to 2000 (NCP, 2003).

Concentrations of Se were compared to those of laboratory toxicity tests and wildlife guidelines. Multiple studies have concluded bioaccumulation in the food chain is the primary source of Se toxicity to fish (see review by Hamilton, 2004). Several Se studies were included in a review by Jarvinen and Ankley (1999) on the effects of inorganic chemicals to aquatic organisms. Various studies from this review showed that whole body concentrations of Se between 8 and $16 \mu \mathrm{g} / \mathrm{g} \mathrm{dw}$ have led to reproductive failure in fathead minnows (Pimephales promelas) (Schultz and Hermanutz, 1990) and bluegill (Coyle and others, 1993; Gillespie and 
Table 8. Percent of samples and stations that exceeded limit of detection (LOD) concentrations for elemental contaminants in composite samples of whole fish from the Yukon River Basin in 2002. The maximum concentrations and associated sample information (station, gender, and species) from this study are also given. NA, not applicable.

\begin{tabular}{|c|c|c|c|c|c|c|c|}
\hline \multirow{2}{*}{ Analyte } & \multirow{2}{*}{$\begin{array}{l}\text { Samples } \\
\text { (\% of } 31)\end{array}$} & \multirow{2}{*}{$\begin{array}{l}\begin{array}{l}\text { Stations } \\
(\% \text { of } 10)\end{array} \\
\end{array}$} & \multirow{2}{*}{$\begin{array}{l}\text { LOD Range } \\
(\mu \mathrm{g} / \mathrm{g})\end{array}$} & \multicolumn{4}{|c|}{ Maximum 2002 Concentration } \\
\hline & & & & $(\mu \mathrm{g} / \mathrm{g})$ & Station & Gender & Species \\
\hline Arsenic & 100 & 100 & NA & 1.95 & Kotlik (310) & M & Burbot \\
\hline Cadmium & 29 & 50 & $0.020-0.027$ & 0.12 & $\begin{array}{l}\text { Charley-Kandik } \\
\text { (301) }\end{array}$ & $\mathrm{F}$ & Longnose sucker \\
\hline Chromium & 84 & 100 & $0.215-0.256$ & 1.64 & $\begin{array}{l}\text { Charley-Kandik } \\
\text { (301) }\end{array}$ & $\mathrm{F}$ & Longnose sucker \\
\hline Copper & 100 & 100 & NA & 1.49 & $\begin{array}{l}\text { Charley-Kandik } \\
\text { (301) }\end{array}$ & $\mathrm{F}$ & Longnose sucker \\
\hline Lead & 0 & 0 & $0.205-0.273$ & NA & NA & NA & NA \\
\hline Mercury & 100 & 100 & NA & 0.65 & Tolovana (306) & $\mathrm{F}$ & Northern pike \\
\hline Nickel & 10 & 30 & $0.205-0.273$ & 0.71 & $\begin{array}{l}\text { Charley-Kandik } \\
\text { (301) }\end{array}$ & F & Longnose sucker \\
\hline Selenium & 100 & 100 & NA & 0.85 & Fairbanks (305) & M & Burbot \\
\hline Zinc & 100 & 100 & NA & 56 & Innoko (309) & $\mathrm{F}$ & Northern pike \\
\hline
\end{tabular}

Baumann, 1986; Hermanutz and others, 1992). Another study concluded Se residues present in the egg stage or at hatch likely affects larval survival (Coyle and others, 1993). These results indicate that it is essential to examine multiple life stages to correctly assess toxicity/tissue concentration relationships (Jarvinen and Ankley, 1999). In addition, Se toxicity has been correlated with various conditions including swelling of gill lamellae, elevated lymphocyte count, anemia, corneal cataracts, exopthlamus, pathological alterations of liver, kidney, heart, and ovary, reproductive failure, and teratogenic deformities of spine, head, mouth, and fins (Hamilton, 2004; Lemly, 2002). Whole body concentrations of Se should not exceed $4 \mu \mathrm{g} / \mathrm{g} \mathrm{dw}(0.8 \mu \mathrm{g} / \mathrm{g}$ ww assuming $80 \%$ moisture $)$ to avoid toxicity to the fish and $3 \mu \mathrm{g} / \mathrm{g} \mathrm{dw}(0.6 \mu \mathrm{g} / \mathrm{g}$ ww assuming $80 \%$ moisture) to avoid toxicity to piscivorous wildlife according to Lemly (1996) and other studies (see review by Hamilton, 2004). Northern pike from Stations 301 and 302, longnose sucker from Stations 301, 304, and 305, and burbot from Station 305 exceeded either one or both thresholds. Therefore, concentrations of Se are of concern at some YRB stations.

\section{Mercury}

Mercury was detected $(>0.01 \mu \mathrm{g} / \mathrm{g} \mathrm{ww})$ in all composite samples, with the maximum $(0.65 \mu \mathrm{g} / \mathrm{g} \mathrm{ww})$ concentration measured in female northern pike from Station 306 (Table 8). Concentrations of $\mathrm{Hg}$ were greatest in predatory fishes and were $>0.3 \mu \mathrm{g} / \mathrm{g}$ ww in samples from Stations 304, 305, 306, 307, and 308 (Fig. 5). The geometric mean was greatest in fish from Station $304(0.41 \mu \mathrm{g} / \mathrm{g} \mathrm{ww})$ followed by Stations 307 $(0.39 \mu \mathrm{g} / \mathrm{g} \mathrm{ww})$ and 306 (0.36 $\mu \mathrm{g} / \mathrm{g} w w)$ (Table 9). Among- station differences for concentrations of $\mathrm{Hg}$ were significant in northern pike but not in longnose sucker or burbot (Table 10). Concentrations of $\mathrm{Hg}$ were significantly greater in northern pike from Station 304 compared to Station 310 (Table 10).

Predatory fish (northern pike, burbot) tend to accumulate greater concentrations of $\mathrm{Hg}$ than forager fish (longnose sucker) (Fig. 5; Schmitt and others, 1999b), and concentrations in predatory fish increase with size (that is, heavier and longer fish have greater concentrations of $\mathrm{Hg}$ ). Therefore, it becomes necessary to examine concentrations of $\mathrm{Hg}$ adjusted for weight and length. However, it is difficult to relate the concentrations of $\mathrm{Hg}$ in composite samples to individual length and weight measurements, but overall trends or patterns can be identified. Concentrations of $\mathrm{Hg}$ were different than length- and weight- adjusted concentrations $(\mathrm{HgL}$ and $\mathrm{HgW}$, respectively) although changes were not consistent among species (Fig. 5). In general, concentrations of $\mathrm{HgW}$ were lower and concentrations of $\mathrm{HgL}$ were greater in northern pike compared to unadjusted concentrations (Fig. 5). The $\mathrm{HgW}$ model did not indicate any spatial differences in $\mathrm{Hg}$ for northern pike (Table 10) and would indicate this model did not accurately describe concentrations of $\mathrm{Hg}$. However, the $\mathrm{HgL}$ model showed similar results but had greater mean concentrations at all stations compared to concentrations in the unadjusted model in terms of spatial differences. For example, concentrations of $\mathrm{Hg}$ were significantly less in northern pike from Station 310 than Station 304 for both unadjusted and lengthadjusted models (Table 10). It is not possible with the current study design (that is, measuring concentrations in composite samples) to definitively account for the contribution of size to concentrations of Hg. However, our results indicate patterns of concentrations in northern pike were similar for $\mathrm{Hg}$ and 
Table 9. Unweighted geometric mean, minimum, and maximum concentrations ( $\mu \mathrm{g} / \mathrm{g}$, wet-weight) of elemental contaminants in fish collected in the Yukon River Basin in 2002. Censored values were replaced by one-half the value for the LOD for the computation of station means, but only if at least one value exceeded detection limits. The maximum geometric station mean is shown in bold for each contaminant. Stations are listed upstream to downstream.

\begin{tabular}{|c|c|c|c|c|c|c|c|c|c|}
\hline \multirow{2}{*}{ Station } & & \multicolumn{8}{|c|}{ Element } \\
\hline & & As & $\mathrm{Cd}$ & $\mathrm{Cr}$ & $\mathrm{Cu}$ & $\mathrm{Hg}$ & $\mathrm{Ni}$ & $\mathrm{Se}$ & $\mathrm{Zn}$ \\
\hline \multirow{3}{*}{$\begin{array}{l}\text { Charley-Kandik, AK } \\
(301) \\
(n=4)\end{array}$} & Mean & 0.11 & 0.01 & 0.84 & 1.06 & 0.18 & 0.35 & 0.58 & 26.7 \\
\hline & Min. & 0.04 & $<0.02$ & 0.26 & 0.53 & 0.15 & $<0.22$ & 0.47 & 21.5 \\
\hline & Max. & 0.17 & 0.12 & 1.66 & 1.49 & 0.28 & 0.71 & 0.66 & 46.1 \\
\hline \multirow{3}{*}{$\begin{array}{l}\text { Fish Hook Bend, AK } \\
(302) \\
(n=2)\end{array}$} & Mean & 0.08 & $<0.02$ & 0.32 & 0.43 & 0.22 & $<0.23$ & 0.72 & 43.3 \\
\hline & Min. & 0.07 & $<0.02$ & 0.30 & 0.42 & 0.21 & $<0.23$ & 0.72 & 41.5 \\
\hline & Max. & 0.10 & $<0.02$ & 0.32 & 0.49 & 0.26 & $<0.23$ & 0.73 & 49.1 \\
\hline \multirow{3}{*}{$\begin{array}{l}\text { Fort Yukon, AK (303) } \\
(n=2)\end{array}$} & Mean & 0.06 & $<0.02$ & 0.19 & 0.50 & 0.16 & $<0.24$ & 0.56 & 46.6 \\
\hline & Min. & 0.05 & $<0.02$ & $<0.24$ & 0.48 & 0.15 & $<0.23$ & 0.53 & 44.6 \\
\hline & Max. & 0.08 & $<0.02$ & 0.30 & 0.52 & 0.16 & $<0.24$ & 0.58 & 48.4 \\
\hline \multirow{3}{*}{$\begin{array}{l}\text { The Bridge, AK (304) } \\
(n=3)\end{array}$} & Mean & 0.44 & 0.01 & 0.36 & 0.63 & 0.41 & $<0.27$ & 0.46 & 42.2 \\
\hline & Min. & 0.05 & $<0.03$ & 0.28 & 0.52 & 0.19 & $<0.26$ & 0.41 & 19.6 \\
\hline & Max. & 1.08 & 0.09 & 0.85 & 1.16 & 0.56 & $<0.27$ & 0.60 & 51.9 \\
\hline \multirow{3}{*}{$\begin{array}{l}\text { Fairbanks, AK (305) } \\
(n=5)\end{array}$} & Mean & 0.12 & 0.01 & 0.23 & 0.97 & 0.17 & $<0.24$ & 0.61 & 18.4 \\
\hline & Min. & 0.05 & $<0.02$ & $<0.22$ & 0.57 & 0.09 & $<0.22$ & 0.52 & 12.4 \\
\hline & Max. & 0.46 & 0.04 & 0.40 & 1.31 & 0.30 & $<0.24$ & 0.85 & 52.3 \\
\hline \multirow{3}{*}{$\begin{array}{l}\text { Tolovana, AK (306) } \\
(n=4)\end{array}$} & Mean & 0.07 & 0.02 & 0.73 & 0.53 & 0.36 & $<0.25$ & 0.48 & 39.2 \\
\hline & Min. & 0.03 & $<0.03$ & 0.40 & 0.51 & 0.08 & $<0.24$ & 0.46 & 16.5 \\
\hline & Max. & 0.08 & 0.06 & 0.94 & 0.72 & 0.65 & $<0.25$ & 0.59 & 46.2 \\
\hline \multirow{3}{*}{$\begin{array}{l}\text { Tanana, AK (307) } \\
(n=2)\end{array}$} & Mean & 0.17 & $<0.03$ & 0.37 & 0.59 & 0.39 & $<0.25$ & 0.43 & 42.9 \\
\hline & Min. & 0.11 & $<0.02$ & 0.37 & 0.55 & 0.37 & $<0.24$ & 0.43 & 41.5 \\
\hline & Max. & 0.30 & $<0.03$ & 0.38 & 0.61 & 0.42 & $<0.25$ & 0.45 & 45.3 \\
\hline \multirow{3}{*}{$\begin{array}{l}\text { Galena, AK (308) } \\
(n=4)\end{array}$} & Mean & 0.06 & 0.02 & 0.63 & 0.59 & 0.24 & $<0.26$ & 0.42 & 33.2 \\
\hline & Min. & 0.05 & $<0.03$ & 0.35 & 0.44 & 0.10 & $<0.25$ & 0.34 & 15.6 \\
\hline & Max. & 0.07 & 0.10 & 1.26 & 0.97 & 0.34 & $<0.26$ & 0.55 & 46.8 \\
\hline \multirow{3}{*}{$\begin{array}{l}\text { Innoko, AK (309) } \\
(n=2)\end{array}$} & Mean & 0.08 & $<0.03$ & 0.22 & 0.42 & 0.25 & $<0.26$ & 0.24 & 49.8 \\
\hline & Min. & 0.06 & $<0.02$ & $<0.26$ & 0.41 & 0.25 & $<0.24$ & 0.23 & 45.5 \\
\hline & Max. & 0.10 & $<0.03$ & 0.34 & 0.44 & 0.25 & $<0.26$ & 0.25 & 56.4 \\
\hline \multirow{3}{*}{$\begin{array}{l}\text { Kotlik, AK (310) } \\
(n=3)\end{array}$} & Mean & 0.28 & $<0.02$ & 0.17 & 0.51 & 0.12 & $<0.24$ & 0.28 & 39.3 \\
\hline & Min. & 0.21 & $<0.02$ & $<0.24$ & 0.47 & 0.11 & $<0.21$ & 0.23 & 10.5 \\
\hline & Max. & 1.95 & $<0.02$ & 0.24 & 0.62 & 0.13 & $<0.24$ & 0.54 & 45.2 \\
\hline
\end{tabular}

$\mathrm{HgL}$, and stations were identified where $\mathrm{Hg}$ could pose a risk. Future studies may be warranted to address specific concerns for $\mathrm{Hg}$.

Mercury data from the YRB were compared with concentrations from previous studies within the basin. Historical NCBP concentrations of $\mathrm{Hg}$ in longnose sucker $(<0.01-0.14$ $\mu \mathrm{g} / \mathrm{g} \mathrm{ww}$ ) (Schmitt and others, 1999b) were slightly less than concentrations measured in $2002(0.08-0.19 \mu \mathrm{g} / \mathrm{g}$ ww). NCBP data were limited to two years (1981 and 1986) for northern pike (0.12-0.14 $\mu \mathrm{g} / \mathrm{g} \mathrm{ww})$ and one year (1979) for burbot $(0.21$ $\mu \mathrm{g} / \mathrm{g} \mathrm{ww}$ ). Concentrations of $\mathrm{Hg}$ were also measured in whole body samples of northern pike from the MRB (Schmitt and others, 2002a) and RGB (Schmitt and others, 2004). Concentrations were $0.15 \mu \mathrm{g} / \mathrm{g}$ ww in a northern pike from the 
Table 10. Spatial trends of chemical contaminants in fish collected in the Yukon River Basin in 2002. Least-squares mean concentrations (all in $\mu \mathrm{g} / \mathrm{g} \mathrm{ww}$ unless otherwise noted) of mercury $(\mathrm{Hg})$, length-adjusted $\mathrm{Hg}(\mathrm{HgL} ; \mu \mathrm{g} / \mathrm{g} / \mathrm{m} \mathrm{ww})$, weight-adjusted $\mathrm{Hg}$ $(\mathrm{HgW} ; \mu \mathrm{g} / \mathrm{g} / \mathrm{kg} \mathrm{ww})$, and selenium (Se). Values within each group of taxon-station means followed by the same letter are not significantly different $(P<0.01$, Fisher's protected LSD). Also shown are ANOVA F-values and degrees-of-freedom (df), and significance levels ( ${ }^{* *} P \leq 0.01 ;{ }^{*} 0.01<P \leq 0.05$; ns $\left.P>0.05\right)$. Stations are listed upstream to downstream within each taxon grouping.

\begin{tabular}{|c|c|c|c|c|}
\hline \multirow{2}{*}{ Station and Species } & \multicolumn{4}{|l|}{ Contaminant } \\
\hline & $\mathrm{Hg}$ & $\mathrm{HgW}$ & $\mathrm{HgL}$ & $\mathrm{Se}$ \\
\hline \multicolumn{5}{|l|}{ Northern Pike } \\
\hline Charley-Kandik, AK (301) & $0.040 \mathrm{abcd}$ & 0.014 & $0.109 \mathrm{abc}$ & $0.259 \mathrm{de}$ \\
\hline Fish Hook Bend, AK (302) & $0.035 \mathrm{abc}$ & 0.023 & $0.116 \mathrm{abc}$ & $0.472 \mathrm{e}$ \\
\hline Fort Yukon, AK (303) & $0.014 \mathrm{ab}$ & 0.030 & $0.065 \mathrm{ab}$ & $0.259 \mathrm{de}$ \\
\hline The Bridge, AK (304) & $0.210 \mathrm{~d}$ & 0.051 & $0.560 \mathrm{c}$ & $0.162 \mathrm{~cd}$ \\
\hline Fairbanks, AK (305) & $0.022 \mathrm{abc}$ & 0.009 & $0.063 \mathrm{abc}$ & 0.265 cde \\
\hline Tolovana, AK (306) & $0.135 \mathrm{~cd}$ & 0.040 & $0.390 \mathrm{bc}$ & $0.171 \mathrm{~cd}$ \\
\hline Tanana, AK (307) & $0.117 \mathrm{~cd}$ & 0.027 & $0.344 \mathrm{bc}$ & $0.148 \mathrm{~cd}$ \\
\hline Galena, AK (308) & $0.081 \mathrm{~cd}$ & 0.037 & $0.252 \mathrm{bc}$ & $0.102 \mathrm{bc}$ \\
\hline Innoko, AK (309) & $0.041 \mathrm{bcd}$ & 0.017 & $0.137 \mathrm{abc}$ & $0.037 \mathrm{a}$ \\
\hline Kotlik, AK (310) & $0.008 \mathrm{a}$ & 0.004 & $0.024 \mathrm{a}$ & $0.047 \mathrm{ab}$ \\
\hline \multicolumn{5}{|l|}{ Longnose sucker } \\
\hline Charley-Kandik, AK (301) & $0.017 \mathrm{a}$ & $0.047 \mathrm{a}$ & $0.102 \mathrm{a}$ & $0.250 \mathrm{a}$ \\
\hline The Bridge, AK (304) & $0.022 \mathrm{a}$ & $0.028 \mathrm{a}$ & $0.128 \mathrm{a}$ & $0.308 \mathrm{a}$ \\
\hline Fairbanks, AK (305) & $0.008 \mathrm{a}$ & $0.032 \mathrm{a}$ & $0.064 \mathrm{a}$ & $0.266 \mathrm{a}$ \\
\hline Tolovana, AK (306) & $0.005 \mathrm{a}$ & $0.023 \mathrm{a}$ & $0.042 \mathrm{a}$ & $0.279 \mathrm{a}$ \\
\hline Galena, AK (308) & $0.005 \mathrm{a}$ & $0.008 \mathrm{a}$ & $0.034 \mathrm{a}$ & 0.198 a \\
\hline \multicolumn{5}{|l|}{ Burbot } \\
\hline Fairbanks, AK (305) & $0.044 \mathrm{a}$ & $0.014 \mathrm{a}$ & $0.124 \mathrm{a}$ & $0.542 \mathrm{a}$ \\
\hline Kotlik, AK (310) & $0.009 \mathrm{a}$ & 0.008 a & $0.031 \mathrm{a}$ & $0.242 \mathrm{a}$ \\
\hline$F$-value & $7.80 * *$ & $0.98 \mathrm{~ns}$ & $3.93 * *$ & $10.74 * *$ \\
\hline $\mathrm{df}$ (model,error) & 16,14 & 14,16 & 16,14 & 16,14 \\
\hline
\end{tabular}

Upper Missouri River and range from $<0.02$ to $0.18 \mu \mathrm{g} / \mathrm{g}$ ww in northern pike from the upper Rio Grande. Few YRB studies examining whole body concentrations of $\mathrm{Hg}$ were found, although several USFWS studies on NWRs reported concentrations in northern pike muscle. Whole body concentrations of $\mathrm{Hg}$ in northern pike ranged from 0.07 to $0.11 \mu \mathrm{g} / \mathrm{g}$ ww from the Kanuti NWR in 1985 (Mueller and others, 1995) and 0.33$0.91 \mu \mathrm{g} / \mathrm{g}$ ww in northern pike muscle samples from several NWRs in 1991 (Mueller and others, 1996). Mueller and Matz (2002) reported northern pike muscle concentrations ranging from 0.07 to $0.86 \mu \mathrm{g} / \mathrm{g}$ ww in the Innoko NWR in 1996-1997. Jewett and others (2003) measured northern pike muscle concentrations of total $\mathrm{Hg}$ of $1.5 \mu \mathrm{g} / \mathrm{g}$ ww collected in 2000 from a tributary of the lower Yukon River. Duffy and others (1999) determined mean concentrations of $\mathrm{Hg}$ in northern pike $(0.823$ $\mu \mathrm{g} / \mathrm{g} w \mathrm{w})$ and burbot $(0.098 \mu \mathrm{g} / \mathrm{g} \mathrm{ww})$ muscle in the YukonKuskokwim delta region of Alaska. Concentrations of $\mathrm{Hg}$ in fish from this region of Alaska were similar to those measured in fish from rivers in the contiguous U.S. (Duffy and others, 1998; Yeardley and others, 1998). The NCP determined northern pike muscle samples from the Yukon Territory within the YRB to have concentrations of $\mathrm{Hg}<0.5 \mu \mathrm{g} / \mathrm{g}$ ww from 1996 to 2000 (NCP, 2003). Mueller and others (1995) determined northern pike consistently had the greatest concentrations of $\mathrm{Hg}$ of all species, a pattern that was also found in 2002.

Laboratory toxicity test concentrations were compared to $\mathrm{Hg}$ data from the YRB. Many $\mathrm{Hg}$ toxicity studies in adult fish are associated with concentrations that are not environmentally relevant (Wiener and Spry, 1996). Fish are at greatest risk from $\mathrm{Hg}$ at environmental exposure levels during embryonic 


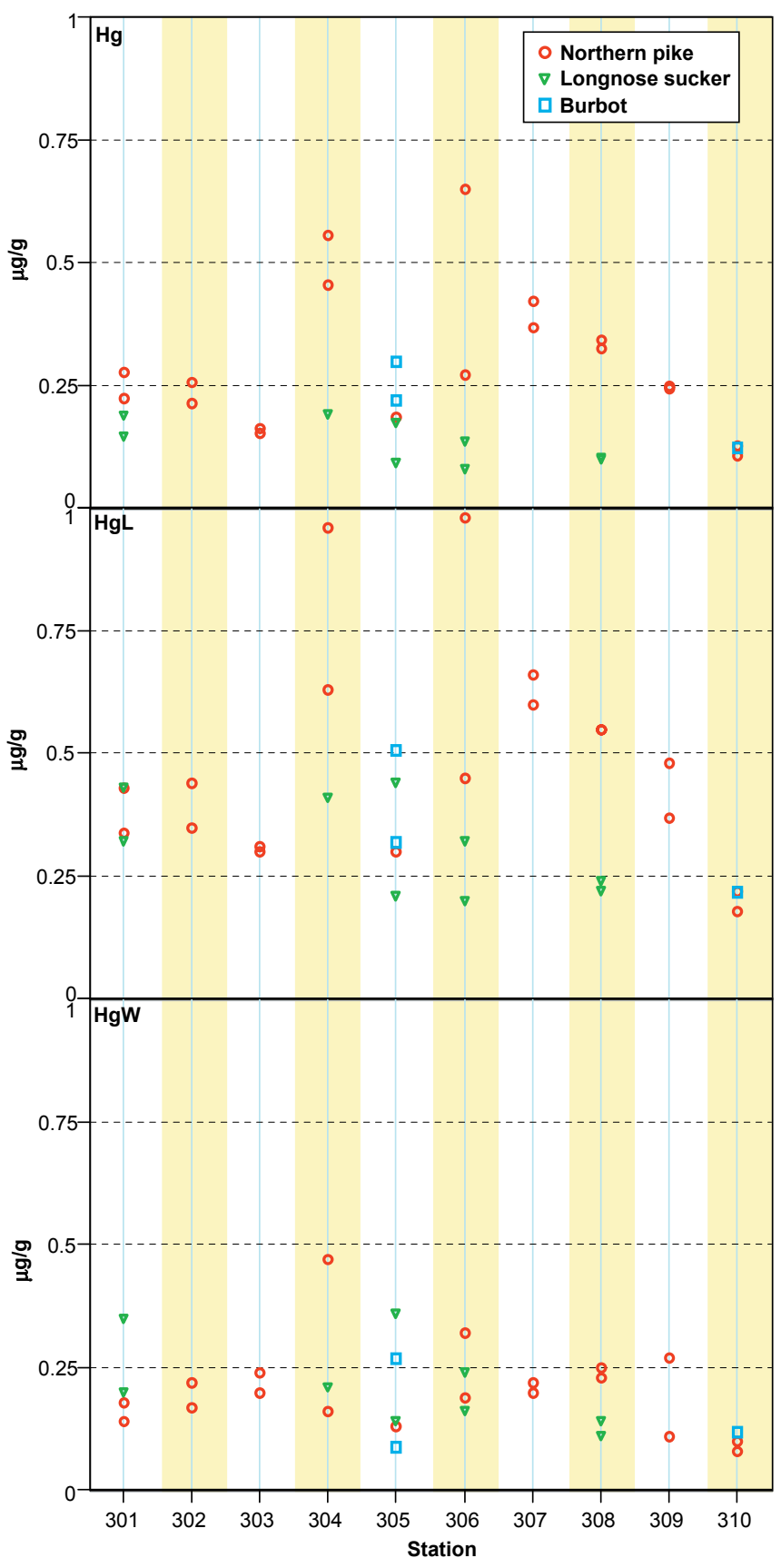

Figure 5. Concentrations $(\mu \mathrm{g} / \mathrm{g} \mathrm{ww})$ of mercury $(\mathrm{Hg})$ by station and species in whole body fish composite samples collected in the Yukon River Basin in 2002. Unadjusted ( $\mathrm{Hg})$, length-adjusted ( $\mathrm{HgL})$, and weight-adjusted ( $\mathrm{HgW}$ ) concentrations are shown. Censored values are plotted as one-half the LOD. Stations are ordered upstream to downstream. See text for computations and Table 1 for station descriptions.

and larval stages partially due to maternal transfer (Wiener and Spry, 1996). Behavioral effects in laboratory studies have been documented in fish containing whole body concentrations of 0.7-5.4 $\mu \mathrm{g} / \mathrm{g}$ ww (Kania and O'Hara, 1974; Wiener and Spry, 1996). Grayling (Thymallus thymallus) fry with concentrations of $0.27 \mu \mathrm{g} / \mathrm{g}$ ww had permanent impairment of their feeding efficiency and competitive ability (Fjeld and others, 1998). Jarvinen and Ankley (1999) reviewed various laboratory studies evaluating the effects of $\mathrm{Hg}$ on reproduction in freshwater fish, including studies that found reduced reproduction at whole body concentrations of $4.47 \mu \mathrm{g} / \mathrm{g} \mathrm{ww}$ in fathead minnows (Snarski and Olson, 1982) and $9.4 \mu \mathrm{g} / \mathrm{g}$ ww in second-generation brook trout (Salvelinus fontinalis) (McKim and others, 1976). Dietary concentrations of $\mathrm{Hg}$ at $0.87 \mu \mathrm{g} / \mathrm{g} \mathrm{dw}$ (about $0.17 \mu \mathrm{g} / \mathrm{g}$ ww assuming $80 \%$ moisture) increased whole body concentrations of $\mathrm{Hg}$ more than 10-fold, suppressed hormone levels, and inhibited gonadal development in female fathead minnows (Drevnick and Sandheinrich, 2003). Whole body concentrations associated with behavioral and reproductive effects were approximately $5 \mu \mathrm{g} / \mathrm{g}$ ww for brook trout and $10 \mu \mathrm{g} / \mathrm{g}$ ww for rainbow trout (Wiener and Spry, 1996; Wiener and others, 2002). However, caution should be used with these thresholds because many factors can contribute uncertainty to these critical tissue concentration estimates (Wiener and others, 2002).

Dietary concentrations of $\mathrm{Hg}$ in wildlife as low as 0.3 $\mu \mathrm{g} / \mathrm{g}$ ww have been associated with reproductive impairment in common loons (Gavia immer) (Barr, 1986), and reproduction in mallards (Anas platyrhynchos) was affected at concentrations as low as $0.1 \mu \mathrm{g} / \mathrm{g}$ ww (Heinz, 1979). Dietary concentrations of $\mathrm{Hg}$ from 0.25 to $1.0 \mu \mathrm{g} / \mathrm{g}$ ww may also be toxic to piscivorous mammals (studies reviewed by Wolfe and others, 1998). Neurotoxicity and mortality occurred in adult mink (Mustela vison) after chronic exposure to dietary concentrations of $\mathrm{Hg}>1 \mu \mathrm{g} / \mathrm{g}$ ww (Dansereau and others, 1999; Wobeser and others, 1976; Wren and others, 1987). Consequently, guidelines for the protection of piscivorous wildlife range from 0.5 to $1.0 \mu \mathrm{g} / \mathrm{g}$ ww (Eisler, 1987; Thompson, 1996) and values as low as $0.1 \mu \mathrm{g} / \mathrm{g}$ ww for mammals and $0.02 \mu \mathrm{g} / \mathrm{g}$ ww for birds have been derived from water quality criteria and bioaccumulation factors (Yeardley and others, 1998). Selenium affords a degree of protection against $\mathrm{Hg}$ toxicity in wildlife by demethylation to inorganic mercury when Se and $\mathrm{Hg}$ are in molar ratio of 1:1 (Dietz and others, 1990; Hamilton, 2004; Heinz and Hoffman, 1998; Scheuhammer and others, 1998; Wiener and others, 2002). However, studies have shown Se-enhanced Hg embryotoxicity in birds (Heinz and Hoffman, 1998). Consequently, reproductive effects may be exacerbated even though significant amounts of Se may protect adult birds from the toxic effects of $\mathrm{Hg}$. Concentrations of $\mathrm{Hg}$ in northern pike at Stations 304, 306, 307, and 308 and burbot from Station 305 exceeded $0.3 \mu \mathrm{g} / \mathrm{g} \mathrm{ww}$, and at least one sample from all stations exceeded $0.1 \mu \mathrm{g} / \mathrm{g}$ ww (Fig. 5). Therefore, our results indicate that $\mathrm{Hg}$ is a cause of concern in YRB.

\section{Lead}

Concentrations of $\mathrm{Pb}$ in fish from the $\mathrm{YRB}$ were $<\mathrm{LOD}$ (0.21-0.27 $\mu \mathrm{g} / \mathrm{g}$ ww) in all composite samples (Table 8). Historical NCBP concentrations of $\mathrm{Pb}$ were also very low $(<0.2 \mu \mathrm{g} / \mathrm{g} \mathrm{ww})$ in northern pike, longnose sucker, and burbot 
(Schmitt and others, 1999b). Several other studies from the region reported similar low concentrations for $\mathrm{Pb}$. Whole body concentration of $\mathrm{Pb}$ were $<\mathrm{LOD}(0.025 \mu \mathrm{g} / \mathrm{g} \mathrm{ww})$ in northern pike samples from the Kanuti NWR in 1985 (Mueller and others, 1995), and concentrations of $\mathrm{Pb}$ were $\angle \mathrm{LOD}$ in northern pike muscle samples from the Innoko and Koyukuk NWRs in recent years (Mueller and Matz, 2002; Snyder-Conn and others, 1992). Lead in sediment from Alaskan placer mining settling ponds within the YRB were less than concentrations that have been determined to affect fish and wildlife (Scannell, 1997). The threshold for the effects of $\mathrm{Pb}$ in fish is $\geq 0.4 \mu \mathrm{g} / \mathrm{g} \mathrm{ww}$ based on whole body concentrations (Holcombe and others, 1976 as reviewed in Jarvinen and Ankley, 1999); therefore, $\mathrm{Pb}$ is not a contaminant of concern in the YRB.

\section{Cadmium}

Concentrations of $\mathrm{Cd}$ in longnose sucker from the $\mathrm{CRB}$ were >LOD $(0.02-0.03 \mu \mathrm{g} / \mathrm{g} \mathrm{ww})$ in nine samples $(29 \%)$ from five stations, whereas concentrations in northern pike and burbot were universally $<$ LOD (Table 8; Fig. 6). All longnose sucker composite samples were $\leq 0.12 \mu \mathrm{g} / \mathrm{g}$ ww with the maximum concentration $(0.12 \mu \mathrm{g} / \mathrm{g} \mathrm{ww})$ measured in females from Station 301 (Fig. 6). The greatest geometric station mean was calculated for samples at Stations 306 and $308(0.02 \mu \mathrm{g} / \mathrm{g} \mathrm{ww})$ (Table 9).

Concentrations of $\mathrm{Cd}$ from the YRB were compared to historical NCBP concentrations in northern pike, longnose sucker, and burbot collected near Fairbanks from 1971 to 1986 (Schmitt and others, 1999b). Concentrations of Cd in northern pike, burbot, and longnose sucker from Station 305 were similar to historical concentrations. Other stations in the basin had concentrations slightly greater than the historical NCBP data. Concentrations of $\mathrm{Cd}$ were $<\mathrm{LOD}$ in northern pike muscle samples from the Koyukuk and Innoko NWRs in 1987 to 1988 (Snyder-Conn and others, 1992). Mueller and others (1995) reported that longnose sucker from Kanuti NWR had greater concentrations of $\mathrm{Cd}$ than other species including northern pike, a pattern that was also apparent in longnose sucker and northern pike concentrations in 2002.

Concentrations of $\mathrm{Cd}$ in fish collected during 2002 in the YRB were compared to laboratory toxicity tests and wildlife criteria. Birds and mammals are comparatively resistant to $\mathrm{Cd}$; dietary toxicity thresholds were $>100 \mu \mathrm{g} / \mathrm{g}$ ww in the studies reviewed by Eisler (1985). Nevertheless, Eisler (1985) suggested that a Cd concentration of $2 \mu \mathrm{g} / \mathrm{g}$ ww in fish is evidence of contamination, that $5 \mu \mathrm{g} / \mathrm{g}$ ww is potentially life-threatening to the fish, and that $13-15 \mu \mathrm{g} / \mathrm{g}$ ww is a threat to higher trophic levels. A review by Jarvinen and Ankley (1999) included several laboratory studies in which whole body concentrations of $\mathrm{Cd}$ in freshwater fish ranging from 0.12 to $15.6 \mu \mathrm{g} / \mathrm{g}$ ww resulted in reduced survival, growth, or both and concentrations of 2-8 $\mu \mathrm{g} / \mathrm{g}$ ww caused decreased spawning and number of embryos produced in freshwater fish.

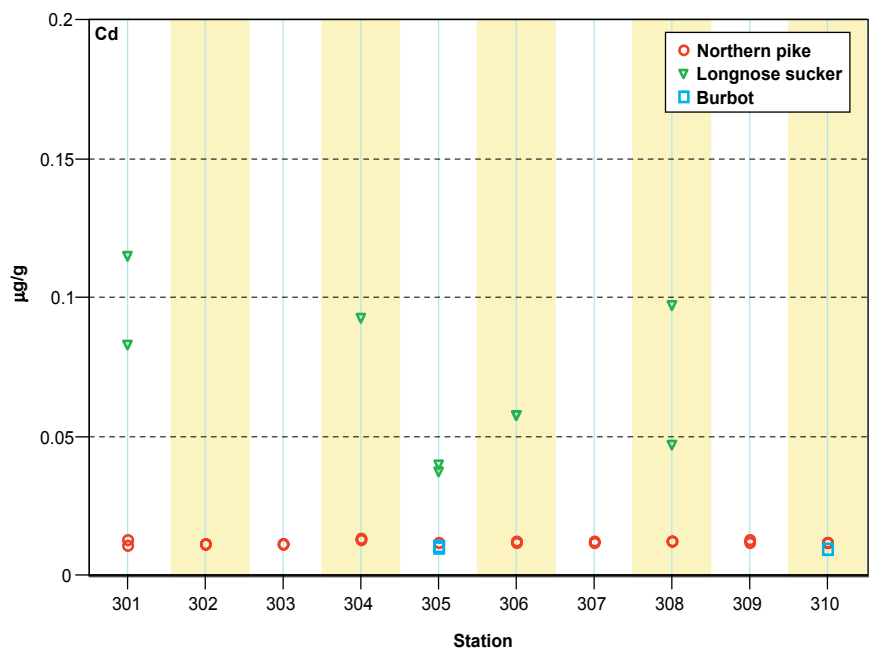

Figure 6. Concentrations ( $\mu \mathrm{g} / \mathrm{g} w w)$ of cadmium (Cd) by station and species in whole body fish composite samples collected in the Yukon River Basin in 2002. Censored values are plotted as onehalf the LOD. Stations are ordered upstream to downstream. See Table 1 for station descriptions.

Concentrations of $\mathrm{Cd}$ in the YRB were less than these benchmarks.

\section{Zinc}

Concentrations of $\mathrm{Zn}$ in fish from the YRB ranged from 10.5 to $56.4 \mu \mathrm{g} / \mathrm{g}$ ww, with the maximum concentration measured in female northern pike from Station 309 (Table 8; Fig. 7). Burbot samples had the lowest concentrations of $\mathrm{Zn}(<15.5 \mu \mathrm{g} / \mathrm{g} \mathrm{ww})$, followed by concentrations in longnose sucker (15.6-30.8 $\mu \mathrm{g} / \mathrm{g} \mathrm{ww})$, and northern pike had the greatest concentrations (35.4-56.4 $\mu \mathrm{g} / \mathrm{g} w w)$. Geometric station means were similar, although fish samples from Stations 301 and 305 had lower concentrations than the other stations (Table 9).

Concentrations of $\mathrm{Zn}$ in 2002 were similar to historical NCBP concentrations collected near Fairbanks (Schmitt and others, 1999b). Northern pike had concentrations of $\mathrm{Zn}$ ranging from 28.6 to $32.2 \mu \mathrm{g} / \mathrm{g}$ ww in 1981 and 1986, which is slightly lower than the concentrations measured in 2002 samples. Concentrations of $\mathrm{Zn}$ in burbot $(8.5 \mu \mathrm{g} / \mathrm{g} \mathrm{ww})$ were only available for 1979. Concentrations in longnose sucker from 1979 to 1984 ranged from 13.3 to $16.5 \mu \mathrm{g} / \mathrm{g}$ ww. YRB concentrations of $\mathrm{Zn}$ in northern pike were similar to concentrations from the RGB (28-56 $\mu \mathrm{g} / \mathrm{g} w \mathrm{w})$ and MRB (31.8 $\mu \mathrm{g} / \mathrm{g}$ ww) although sample sizes were limited (Schmitt and others, 2002a; 2004). Other studies measuring whole body concentrations of $\mathrm{Zn}$ in northern pike, longnose sucker, and burbot from the YRB were not found. The USFWS has sampled multiple NWRs in the YRB, but these studies measured concentrations $<10 \mu \mathrm{g} / \mathrm{g} w w$ in northern pike muscle only. Sun and Jeng 


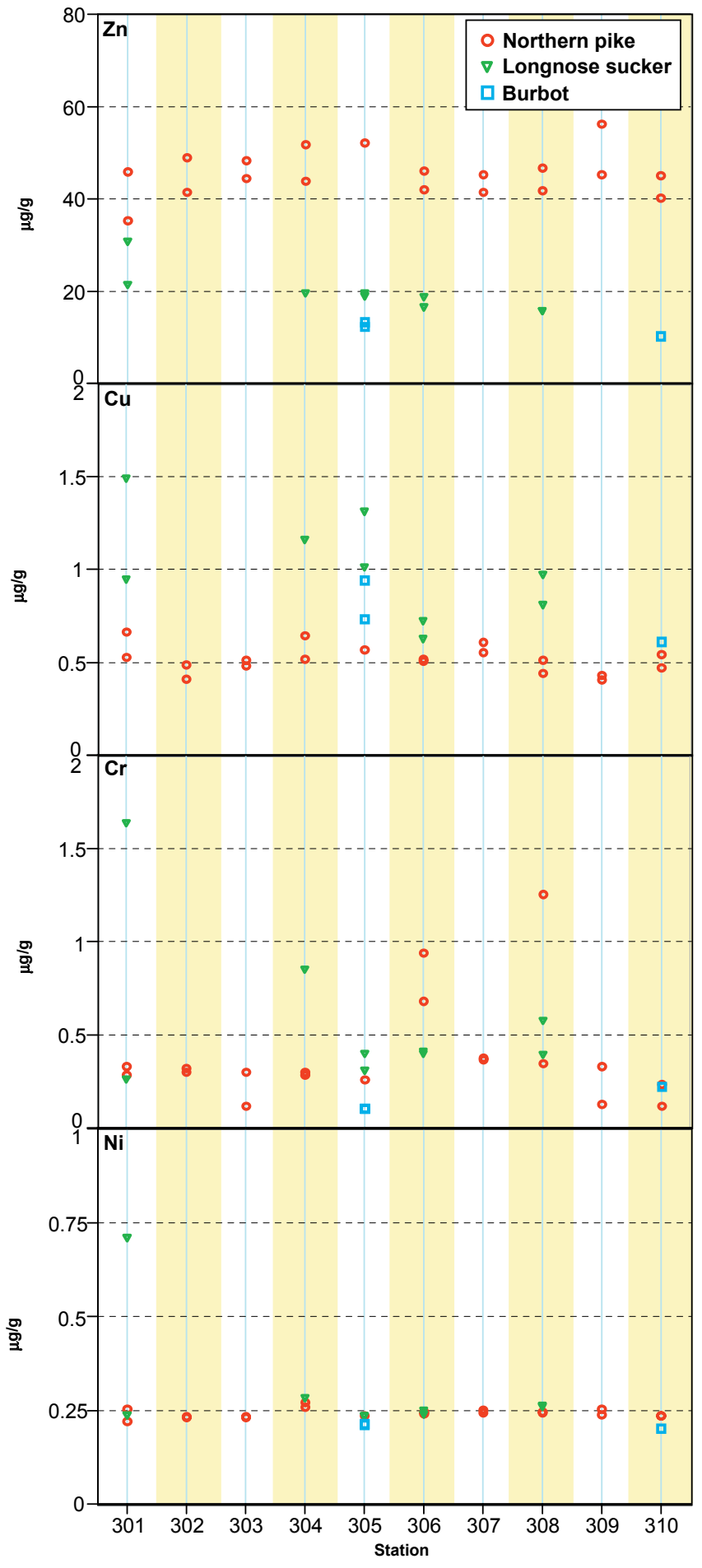

Figure 7. Concentrations ( $\mu \mathrm{g} / \mathrm{g} \mathrm{ww})$ of zinc $(\mathrm{Zn})$, copper (Cu), chromium ( $\mathrm{Cr}$ ), and nickel (Ni) by station and species in whole body fish composite samples collected in the Yukon River Basin in 2002. Censored values are plotted as one-half the LOD. Stations are ordered upstream to downstream. See Table 1 for station descriptions.
(1998) determined that fish species vary in Zn partitioning in tissues. Muscle tissues had lower concentrations of $\mathrm{Zn}$ compared to most other tissues examined including digestive tract tissue, liver, kidney, gonad, gill, and skeletal tissues (Sun and Jeng, 1998). Therefore, it may be inappropriate to compare 2002 concentrations with USFWS northern pike data. Concentrations of $\mathrm{Zn}$ in sediment from Alaskan placer mining settling ponds in the YRB were less than concentrations that have been determined to affect fish and wildlife (Scannell, 1997).

Laboratory toxicity tests for $\mathrm{Zn}$ were limited as well. The growth and survival of American flagfish (Jordanella floridae), a cyprinid, exposed over a life-cycle (larvae-to-adult) were affected at concentrations of 40-64 $\mu \mathrm{g} / \mathrm{g}$ ww (Spehar, 1976 as cited by Jarvinen and Ankley, 1999). Eisler (1993) concluded that it is unlikely that either fish or higher trophic level organisms are adversely affected by $\mathrm{Zn}$. Concentrations of $\mathrm{Zn}$ do not appear to be a contaminant of concern in northern pike, longnose sucker, and burbot collected from the YRB.

\section{Copper}

Copper was detected in all samples at concentrations ranging from 0.41 to $1.49 \mu \mathrm{g} / \mathrm{g} w \mathrm{w}$, with the maximum measured in female longnose sucker from Station 301 (Table 8). Longnose sucker samples consistently had greater concentrations of $\mathrm{Cu}(>0.62 \mu \mathrm{g} / \mathrm{g} \mathrm{ww})$ compared to northern pike (most $<0.60 \mu \mathrm{g} / \mathrm{g} \mathrm{ww}$ ) (Fig. 7). Concentrations of $\mathrm{Cu}$ were greatest in longnose sucker from Stations 301, 304, and 305, and fish samples from Stations 301 and 305 had the greatest geometric stations means (1.06 and $0.97 \mu \mathrm{g} / \mathrm{g}$ ww, respectively) (Table 9).

YRB concentrations of $\mathrm{Cu}$ were compared to NCBP data collected from 1979 to 1986 (Schmitt and others, 1999b). Historical concentrations were less than 2002 concentrations in burbot and northern pike, whereas historical concentrations of $\mathrm{Cu}(0.6-1.2 \mu \mathrm{g} / \mathrm{g} \mathrm{ww})$ in longnose sucker were similar to 2002 concentrations at Station 305 (1.0-1.3 $\mu \mathrm{g} / \mathrm{g} \mathrm{ww})$. Concentrations of $\mathrm{Cu}$ in northern pike from the RGB in 1997 were slightly greater (0.74-1.0 $\mu \mathrm{g} / \mathrm{g} \mathrm{ww})$ (Schmitt and others, 2004) than YRB northern pike concentrations. Additional studies examining whole body concentrations of $\mathrm{Cu}$ in northern pike, longnose sucker, and burbot were not found. However, the USFWS collected northern pike muscle samples from the Koyukuk and Innoko NWRs in the YRB (Mueller and Matz, 2002; Snyder-Conn and others, 1992). Concentrations in these studies were less than 2002 concentrations $(<0.4 \mu \mathrm{g} / \mathrm{g}$ ww) although this may be attributed to the partitioning of $\mathrm{Cu}$ into tissues other than muscle, primarily the liver (Aaseth and Norseth, 1986) and kidney (West and Deschu, 1984). Mueller and others (1995) reported that longnose sucker from the Kanuti NWR had greater concentrations of $\mathrm{Cu}$ than other species including northern pike, a pattern that was also apparent in our data. Scannell (1997) concluded that concentrations of $\mathrm{Cu}$ in sediment from Alaskan placer mining settling ponds 
were less than concentrations that negatively affect fish and wildlife.

The ecological relevance of the concentrations of $\mathrm{Cu}$ in fish from the YRB is unknown. Of the studies reviewed by Jarvinen and Ankley (1999), only the work of Stouthart and others (1996) was relevant; these authors determined that concentrations of 11.1-11.7 $\mu \mathrm{g} / \mathrm{g} \mathrm{ww}$ were associated with reduced survival of carp larvae, and concentrations of $42 \mu \mathrm{g} / \mathrm{g}$ ww reduced egg survival. However, no tissue-based criteria for $\mathrm{Cu}$ are available for the protection of avian and mammalian wildlife (Eisler, 1997).

\section{Chromium and Nickel}

Concentrations of $\mathrm{Cr}$ were $>\mathrm{LOD}(0.22-0.26 \mu \mathrm{g} / \mathrm{g} \mathrm{ww})$ in 29 of 31 composite samples (84\%) from all stations (Table 8). Concentrations ranged from 0.23 to $1.64 \mu \mathrm{g} / \mathrm{g}$ ww, with the maximum concentration measured in female longnose sucker from Station 301 (Table 8; Fig. 7). Geometric station means in fish were $<0.84 \mu \mathrm{g} / \mathrm{g}$ ww (Table 9). Concentrations of $\mathrm{Cr}$ were not determined by the NCBP (Schmitt and others, 1999b). Concentrations of $\mathrm{Cr}$ in northern pike from the RGB in 1997 (0.28-0.88 $\mu \mathrm{g} / \mathrm{g} \mathrm{ww})$ (Schmitt and others, 2004) were less than those in the YRB. Additional studies examining whole body concentrations of $\mathrm{Cu}$ in northern pike, longnose sucker, and burbot were not found. However, the USFWS collected northern pike muscle samples from the Koyukuk and Innoko NWRs in the YRB (Mueller and Matz, 2002; Snyder-Conn and others, 1992). These studies reported few concentrations of $\mathrm{Cr}$ $>$ LOD in northern pike muscle, possibly as a result of $\mathrm{Cr}$ accumulating in other tissues (Langard and Norseth, 1986). Eisler (1986) suggested that concentrations of $\mathrm{Cr}>4 \mu \mathrm{g} / \mathrm{g}$ ww may be considered contaminated; however, the significance of such a value is unclear. A review of the literature (Jarvinen and Ankley, 1999) did not find studies linking whole body residues of $\mathrm{Cr}$ to survival or growth effects in freshwater fishes.

Concentrations of Ni were $>$ LOD $(0.21-0.27 \mu \mathrm{g} / \mathrm{g}$ ww) in 2 of 31 composite samples (6\%) (Table 8). Concentrations ranged from 1.0 to $2.9 \mu \mathrm{g} / \mathrm{g}$ ww, with the maximum concentration measured in female longnose sucker from Station 301 (Table 8; Fig. 7). Geometric station means were $<$ LOD for all samples, with the exception of fish from Station 301 ( $0.35 \mu \mathrm{g} / \mathrm{g} \mathrm{ww}$ ) (Table 9). Whole body concentrations of Ni ranged from 0.19 to $0.73 \mu \mathrm{g} / \mathrm{g} w \mathrm{w}$ in northern pike from the RGB (Schmitt and others, 2004). Concentrations of Ni in most northern pike muscle samples from various NWRs in the YRB were also <LOD (Mueller and others, 1995; Mueller and Matz, 2002; Snyder-Conn, 1992). Scannell (1997) determined that concentrations of $\mathrm{Ni}$ in sediment from Alaskan placer mining settling ponds were less than concentrations that negatively affect fish and wildlife. Like $\mathrm{Cu}$, studies are lacking for linkages of whole body concentrations to effects for $\mathrm{Ni}$ (Jarvinen and Ankley, 1999), and tissue-based criteria for the protection of fishes and piscivorous wildlife are not available.
Data for additional elements and other data from this study are available at $<$ http://www.cerc.usgs.gov/data/search. $h t m>$.

\section{Organochlorine Chemicals}

\section{DDT and Its Primary Metabolites}

DDT, a persistent organochlorine insecticide, and its metabolites remain present in the environment as a consequence of atmospheric transport and from historical use in the U.S. until 1972. Elevated concentrations of residues derived from DDT are most common in cotton-growing areas of the U.S. and near former sites of production and formulation, although atmospheric transport from sites where DDT is still used can also deposit these chemicals (Schmitt and others, 2002a). We found the parent compound, $p, p$ '-DDT, at concentrations $>$ LOD $(0.0007-0.0008 \mu \mathrm{g} / \mathrm{g} w w)$ in only 2 of 31 samples $(6 \%)$. Both detected samples were from Station 305 (Table 11), and $p, p$ '-DDT accounted for $31 \%$ of the total detected DDT ( $p, p^{\prime}$-homologs) in fish sampled in 2002 (Fig. 8). The greatest concentrations (individual samples and geometric station means) were in female northern pike (0.0091 $\mu \mathrm{g} / \mathrm{g} \mathrm{ww})$ and male longnose sucker $(0.0047 \mu \mathrm{g} / \mathrm{g} \mathrm{ww})$ from Station 305 (Tables 11 and 12).

The major metabolite of $p, p^{\prime}$-DDT, $p, p^{\prime}$-DDE, was detected in 25 of 31 fish composites (Table 11) and accounted for $44 \%$ of the total detected DDT (Fig. 8). Fish samples from Station 304 had concentrations <LOD $(0.0002 \mu \mathrm{g} / \mathrm{g}$ ww), whereas the female longnose sucker sample from Station 305 had the greatest concentration of $p, p^{\prime}-\mathrm{DDE}(0.005 \mu \mathrm{g} / \mathrm{g} \mathrm{ww})$ (Fig. 9).

YRB concentrations of $p, p^{\prime}$-DDE were compared to NCBP data collected near Fairbanks from 1969 to 1986 (Schmitt and others, 1999b). Historical data on $p, p^{\prime}$-DDE were limited for northern pike $(1981,1986)$ and burbot (1979) but were greater than those measured in 2002. Longnose sucker had the most extensive historical data (1969-1984) and showed a decreasing $p, p^{\prime}$-DDE trend during the NCBP collection years and continued with 2002 concentrations.

Concentrations of $p, p^{\prime}$-DDD are a result of $p, p^{\prime}$-DDT breakdown and use as an insecticide. This compound accounted for $26 \%$ of the total detected DDT (Fig. 8) and was detected $(\geq 0.0002 \mu \mathrm{g} / \mathrm{g}$ ww) in 18 of 31 composite samples $(81 \%)$ from eight stations (Table 11). Female longnose sucker from Station 305 had the greatest concentration of $p, p$ '-DDD $(0.007 \mu \mathrm{g} / \mathrm{g} \mathrm{ww})$ with all other composite samples having concentrations $<0.004 \mu \mathrm{g} / \mathrm{g}$ ww.

Geometric means for total DDT were highest in fish at Station $305(0.011 \mu \mathrm{g} / \mathrm{g} \mathrm{ww})$, and all other station means were $\leq 0.004 \mu \mathrm{g} / \mathrm{g}$ ww (Table 12). Low historical concentrations of total DDT have been recorded at Station 305 (Schmitt and others, 1999b). Snyder-Conn (1992) reported similar find- 
Table 11. Percent of samples and stations with concentrations exceeding the limit of detection (LOD) for organochlorine chemical residues in composite samples of whole fish in the Yukon River Basin in 2002. The maximum concentrations and associated sample information (station, species, and gender) from this study are also given. ${ }^{a}$ Sum of cis- and trans-chlordanes and nonachlors; oxychlordane; and heptachlor epoxide, with censored values represented as 50\% LOD. ${ }^{b} 1,1 \mathrm{a}, 2,2,3,3 \mathrm{a}, 4,5,5,5 \mathrm{a}, 5 \mathrm{~b}, 6$-Dodecachlorooctahydro-1,3,4-metheno-1H-cyclobuta(cd)pentalene.

\begin{tabular}{|c|c|c|c|c|c|c|}
\hline \multirow{2}{*}{ Analyte(s) } & \multirow{2}{*}{$\begin{array}{l}\text { Samples } \\
(\% \text { of } 31)\end{array}$} & \multirow{2}{*}{$\begin{array}{l}\text { Stations } \\
\text { (\% of } 10)\end{array}$} & \multicolumn{4}{|c|}{ Maximum 2002 Concentration } \\
\hline & & & $\mu \mathrm{g} / \mathrm{g}$ & Station & Gender & Species \\
\hline$p, p$ '-DDT & 6 & 10 & 0.009 & Fairbanks (305) & $\mathrm{F}$ & Northern pike \\
\hline$p, p^{\prime}-\mathrm{DDD}(\mathrm{TDE})$ & 58 & 80 & 0.007 & Fairbanks (305) & $\mathrm{F}$ & Longnose sucker \\
\hline$p, p^{\prime}-\mathrm{DDE}$ & 81 & 100 & 0.005 & Fairbanks (305) & $\mathrm{F}$ & Longnose sucker \\
\hline Total $p, p^{\prime}$-homologs & 81 & 100 & 0.014 & Fairbanks (305) & $\mathrm{F}$ & Northern pike \\
\hline$o, p^{\prime}-\mathrm{DDT}$ & 68 & 70 & 0.003 & Fairbanks (305) & $\mathrm{F}$ & Longnose sucker \\
\hline$o, p '-\mathrm{DDD}(\mathrm{TDE})$ & 10 & 30 & 0.003 & Galena (308) & $\mathrm{F}$ & Longnose sucker \\
\hline$o, p^{\prime}-\mathrm{DDE}$ & 42 & 70 & 0.002 & Charley-Kandik (301) & M & Longnose sucker \\
\hline Dieldrin & 35 & 70 & 0.001 & The Bridge (304) & $\mathrm{F}$ & Longnose sucker \\
\hline Endrin & 35 & 80 & 0.001 & Charley-Kandik (301) & $\mathrm{F}$ & Longnose sucker \\
\hline cis-Chlordane & 29 & 50 & 0.001 & Tolovana (306) & $\mathrm{F}$ & Northern pike \\
\hline trans-Chlordane & 58 & 80 & 0.002 & Tanana (307) & M & Northern pike \\
\hline cis-Nonachlor & 90 & 100 & 0.002 & Fairbanks (305) & M & Longnose sucker \\
\hline trans-Nonachlor & 45 & 70 & 0.002 & Tolovana (306) & $\mathrm{F}$ & Northern pike \\
\hline Oxychlordane & 58 & 80 & 0.003 & Charley-Kandik (301) & $\mathrm{F}$ & Longnose sucker \\
\hline Heptachlor epoxide & 16 & 40 & 0.001 & Fairbanks (305) & $\mathrm{F}$ & Burbot \\
\hline Total chlordane-related residues ${ }^{\text {a }}$ & 94 & 100 & 0.007 & Tolovana (306) & $\mathrm{F}$ & Northern pike \\
\hline Toxaphene & 34 & 80 & 0.034 & Fish Hook Bend (302) & $\mathrm{F}$ & Northern pike \\
\hline $\operatorname{Mirex}^{\mathrm{b}}$ & 32 & 60 & 0.0003 & Fish Hook Bend (302) & M & Northern pike \\
\hline Total PCBs & 90 & 90 & 0.087 & Fairbanks (305) & $\mathrm{F}$ & Longnose sucker \\
\hline
\end{tabular}

ings in the Tanana basin with northern pike and burbot having undetectable or only trace $(0.02 \mu \mathrm{g} / \mathrm{g} \mathrm{ww})$ concentrations of $p, p$ '-DDE. Concentrations of $p, p$ '-DDT in burbot livers collected near Fairbanks were greater than NWR concentrations in the YRB (Mueller and Matz, 2000), with the city of Fairbanks, Fort Wainwright Army Base, and Eielson Air Force Base identified as the probable local contamination sources.

Concentrations of total DDT in our study were compared to laboratory toxicity tests and wildlife criteria. Concentrations of total DDT in fish $>0.15 \mu \mathrm{g} / \mathrm{g}$ ww are potentially harmful to the brown pelican (Pelicanus occidentalis), a sensitive avian species (Anderson and others, 1975), and wildlife criteria as low as $0.20 \mu \mathrm{g} / \mathrm{g}$ ww have been suggested by Newell and others (1987). Concentrations of 1-3 $\mu \mathrm{g} / \mathrm{g} \mathrm{ww}$ are potentially hazardous to most piscivorous birds (see review by Blus, 1996). A review by Jarvinen and Ankley (1999) associated toxic effects of total DDT to fish with whole body concentrations as low as $0.5 \mu \mathrm{g} / \mathrm{g}$ ww. Reduced survival has been reported with whole body concentrations of total DDT in fry or fingerlings of cutthroat trout (O. clarki; $0.57 \mu \mathrm{g} / \mathrm{g}$ ww) (Cuerrier and others, 1967), rainbow trout (1.14-1.42 $\mu \mathrm{g} / \mathrm{g}$ ww) (Cuerrier and others, 1967; Hopkins and others,
1969), brook trout (0.46-5.03 $\mu \mathrm{g} / \mathrm{g} \mathrm{ww})$ (Cuerrier and others, 1967; Macek, 1968), lake trout (S. namaycush; $2.93 \mu \mathrm{g} / \mathrm{g}$ ww) (Burdick and others, 1964), coho salmon (1.09-2.76 $\mu \mathrm{g} / \mathrm{g}$ ww) (Johnson and Pecor, 1969), and chinook salmon (11.6$21.7 \mu \mathrm{g} / \mathrm{g} \mathrm{ww}$ ) (Buhler and others, 1969). Reduced survival has been reported with whole body concentrations of total DDT in juvenile and adult green sunfish (Lepomis cyanellus) and pumpkinseed (L. gibbosus; $24 \mu \mathrm{g} / \mathrm{g}$ ww) (Hamelink and others, 1971), fathead minnows (57-209 $\mu \mathrm{g} / \mathrm{g}$ ww) (Jarvinen and others, 1976; Jarvinen and others, 1977), and goldfish

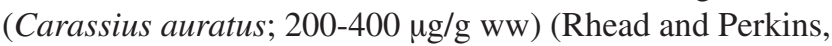
1984). Concentrations of total DDT in 2002 were less than these benchmarks and were not identified as hazardous to fish or wildlife in the YRB.

Technical DDT contains $o, p$ '-DDT as an impurity, and residues of this compound and its metabolites also remain widespread (Schmitt and others, 1985; 1999b; 2002a). Comparatively low concentrations of $o, p^{\prime}$-DDT $(<0.0001-0.003$ $\mu \mathrm{g} / \mathrm{g} \mathrm{ww}$ ) were detected in composite samples from the YRB. The $o, p^{\prime}$-homologs have historically been considered relatively benign, although $o, p^{\prime}$-DDD has been shown to be weakly estrogenic (Ackerman and others, 2002; Guillette and others, 


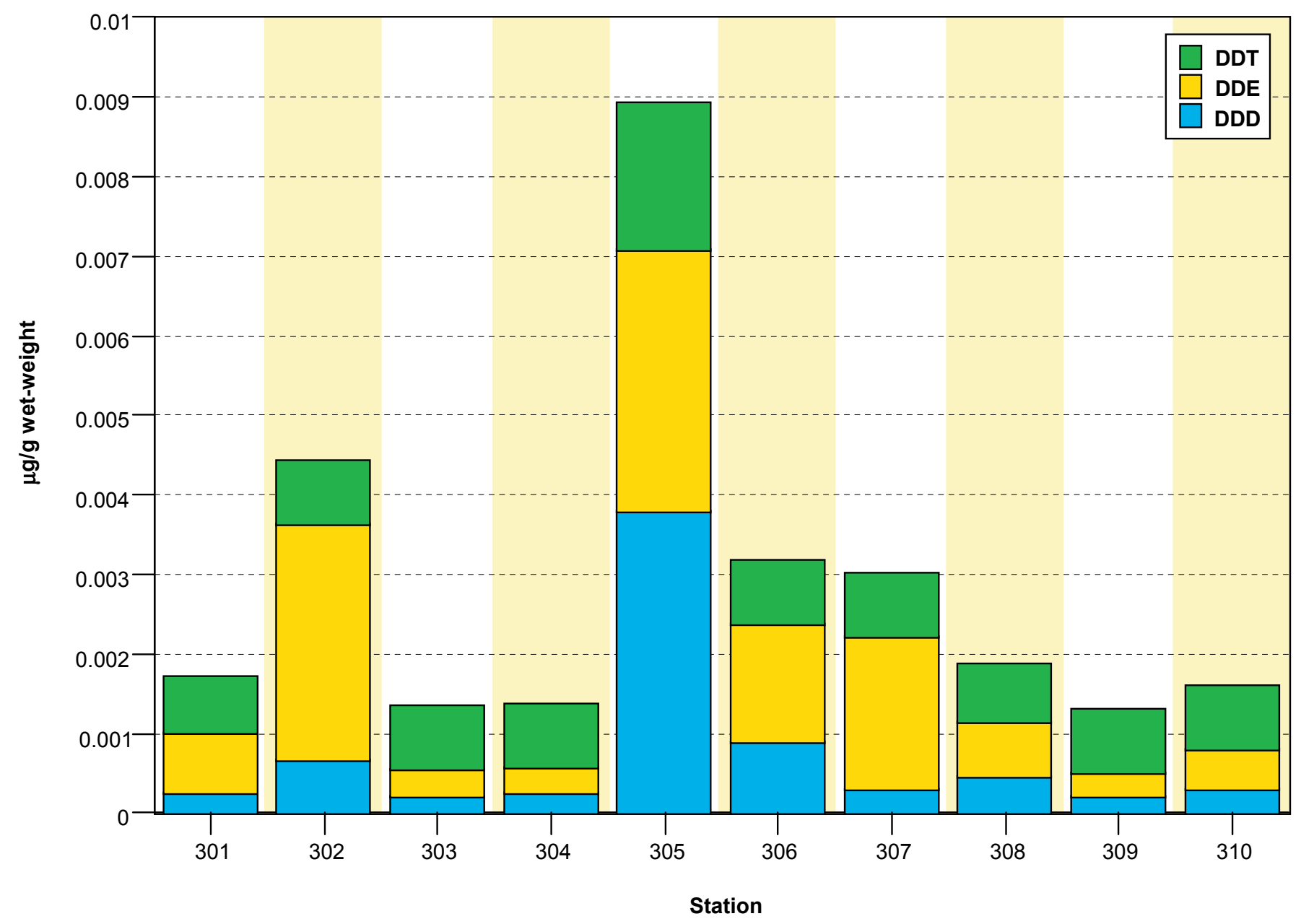

Figure 8. Weighted geometric mean concentrations ( $\mu \mathrm{g} / \mathrm{g} w w)$ of $p, p^{\prime}-\mathrm{DDT}, \mathrm{DDE}$, and DDD by station in whole body fish composite samples collected in the Yukon River Basin in 2002. Censored values are represented by one-half the LOD in the computation of means and totals but are not shown in the figure. Stations are ordered upstream to downstream. See Table 1 for station descriptions.

1996; Toppari and others, 1996), as are many other pesticides and their metabolites (Tyler and others, 1998). The total risk to fish and wildlife represented by concentrations of $o, p^{\prime}$-DDT is unknown, but these chemicals are not considered to be of concern at the concentrations measured in 2002.

\section{Cyclodiene Pesticides}

\section{Chlordane and Heptachlor}

Chlordane is a mixture of cyclopentadiene-derived compounds that was widely used as a soil insecticide. Concentrations of these compounds are typically greatest in fish from corn-growing regions, urban areas in the "termite belt", and near production and formulation facilities (Schmitt, 2002b; Schmitt and others, 1999b) and were not expected to measured at high concentrations in the YRB. Six chlordane-related components and metabolites were measured in the 2002 samples including cis-chlordane, trans-chlordane, cis-nonachlor, trans-nonachlor, oxychlordane, and heptachlor epoxide (Table 11). Concentrations of all six chlordane-related compounds were low $(<0.003 \mu \mathrm{g} / \mathrm{g} \mathrm{ww})$ in all composite samples (Table 11). NCBP concentrations from fish samples collected from 1977 to 1986 for all of these compounds were $<$ LOD $(<0.005-$ $0.01 \mu \mathrm{g} / \mathrm{g} \mathrm{ww}$; Schmitt and others, 1999b). Snyder-Conn (1992) also reported chlordane compounds <LOD $(0.01 \mu \mathrm{g} / \mathrm{g}$ ww) in northern pike and burbot from a lake within the YRB.

Concentrations of total chlordanes (sum of six compounds) in 2002 ranged from $<0.001$ to $0.007 \mu \mathrm{g} / \mathrm{g} w \mathrm{w}$, with the maximum concentration measured in female northern pike from Station 306 (Fig. 9). All geometric station means for total chlordane were $\leq 0.005 \mu \mathrm{g} / \mathrm{g}$ ww (Table 12; Fig. 10). All fish samples from the YRB had concentrations of total chlordane $<0.1 \mu \mathrm{g} / \mathrm{g} w \mathrm{w}$, the level of concern for the health of predatory fish and fish-eating birds (Eisler, 1990).

\section{Dieldrin}

Most environmental dieldrin is present due to the break- 
Table 12. Unweighted geometric mean, minimum, and maximum concentrations $(\mu \mathrm{g} / \mathrm{g} \mathrm{ww})$ of organochlorine chemical contaminants in fish collected from stations in the Yukon River Basin in 2002. Censored values were replaced by one-half of the value for the LOD for the computation of station means, but only if at least one value exceeded LOD. Total DDT are the total of $p, p^{\prime}$-DDT homologs. Total PCBs is the sum of all congeners. Total chlordane is the sum of cis-chlordane, trans-chlordane, cis-nonachlor, trans-nonachlor, heptachlor epoxide and oxychlordane. The maximum geometric station mean is shown in bold for each contaminant. Stations are listed upstream to downstream.

\begin{tabular}{|c|c|c|c|c|c|c|}
\hline Station & & $\begin{array}{l}\text { Total } \\
\text { DDT }\end{array}$ & Dieldrin & $\begin{array}{l}\text { Total } \\
\text { PCBs }\end{array}$ & Toxaphene & $\begin{array}{l}\text { Total } \\
\text { Chlordane }\end{array}$ \\
\hline \multirow{3}{*}{$\begin{array}{l}\text { Charley-Kandik, AK } \\
(301) \\
(n=4)\end{array}$} & Mean & 0.002 & 0.0001 & 0.036 & 0.007 & 0.003 \\
\hline & Min. & 0.001 & $<0.0002$ & 0.025 & $<0.011$ & 0.001 \\
\hline & Max. & 0.004 & 0.0002 & 0.040 & 0.033 & 0.004 \\
\hline \multirow{2}{*}{$\begin{array}{l}\text { Fish Hook Bend, AK } \\
(302)\end{array}$} & Mean & 0.004 & $<0.0002$ & 0.042 & 0.032 & 0.003 \\
\hline & Min. & 0.004 & $<0.0002$ & 0.040 & 0.029 & 0.003 \\
\hline$(n=2)$ & Max. & 0.005 & $<0.0002$ & 0.048 & 0.034 & 0.004 \\
\hline \multirow{3}{*}{$\begin{array}{l}\text { Fort Yukon, AK (303) } \\
(n=2)\end{array}$} & Mean & 0.001 & $<0.0002$ & $<0.02$ & $<0.011$ & 0.001 \\
\hline & Min. & 0.001 & $<0.0002$ & $<0.02$ & $<0.011$ & 0.001 \\
\hline & Max. & 0.002 & $<0.0002$ & $<0.02$ & $<0.011$ & 0.001 \\
\hline \multirow{3}{*}{$\begin{array}{l}\text { The Bridge, AK (304) } \\
(n=3)\end{array}$} & Mean & 0.001 & 0.0003 & 0.031 & 0.010 & 0.005 \\
\hline & Min. & 0.001 & $<0.0002$ & 0.025 & $<0.011$ & 0.003 \\
\hline & Max. & 0.002 & 0.0006 & 0.033 & 0.013 & 0.006 \\
\hline \multirow{3}{*}{$\begin{array}{l}\text { Fairbanks, AK (305) } \\
(n=5)\end{array}$} & Mean & 0.011 & 0.0001 & 0.062 & 0.007 & 0.002 \\
\hline & Min. & 0.007 & $<0.0002$ & 0.039 & $<0.011$ & 0.001 \\
\hline & Max. & 0.014 & 0.0003 & 0.087 & 0.019 & 0.004 \\
\hline \multirow{3}{*}{$\begin{array}{l}\text { Tolovana, AK (306) } \\
(n=4)\end{array}$} & Mean & 0.004 & 0.0003 & 0.039 & 0.017 & 0.004 \\
\hline & Min. & 0.003 & $<0.0002$ & 0.026 & $<0.011$ & 0.002 \\
\hline & Max. & 0.005 & 0.0004 & 0.063 & 0.030 & 0.007 \\
\hline \multirow{3}{*}{$\begin{array}{l}\text { Tanana, AK (307) } \\
(n=2)\end{array}$} & Mean & 0.003 & 0.0004 & 0.030 & 0.009 & 0.003 \\
\hline & Min. & 0.002 & 0.0004 & 0.029 & $<0.011$ & 0.002 \\
\hline & Max. & 0.004 & 0.0005 & 0.031 & 0.014 & 0.005 \\
\hline \multirow{3}{*}{$\begin{array}{l}\text { Galena, AK (308) } \\
(n=4)\end{array}$} & Mean & 0.002 & 0.0002 & 0.022 & 0.008 & 0.003 \\
\hline & Min. & 0.001 & $<0.0002$ & 0.019 & $<0.011$ & 0.003 \\
\hline & Max. & 0.002 & 0.0003 & 0.029 & 0.018 & 0.005 \\
\hline \multirow{3}{*}{$\begin{array}{l}\text { Innoko, AK (309) } \\
(n=2)\end{array}$} & Mean & 0.001 & $<0.0002$ & 0.024 & 0.009 & 0.001 \\
\hline & Min. & 0.001 & $<0.0002$ & 0.023 & $<0.011$ & 0.001 \\
\hline & Max. & 0.002 & $<0.0002$ & 0.025 & 0.016 & 0.003 \\
\hline \multirow{3}{*}{$\begin{array}{l}\text { Kotlik, AK (310) } \\
(n=3)\end{array}$} & Mean & 0.002 & 0.0001 & 0.015 & $<0.011$ & 0.003 \\
\hline & Min. & 0.001 & $<0.0002$ & $<0.02$ & $<0.011$ & 0.002 \\
\hline & Max. & 0.002 & 0.0003 & 0.022 & $<0.011$ & 0.004 \\
\hline
\end{tabular}




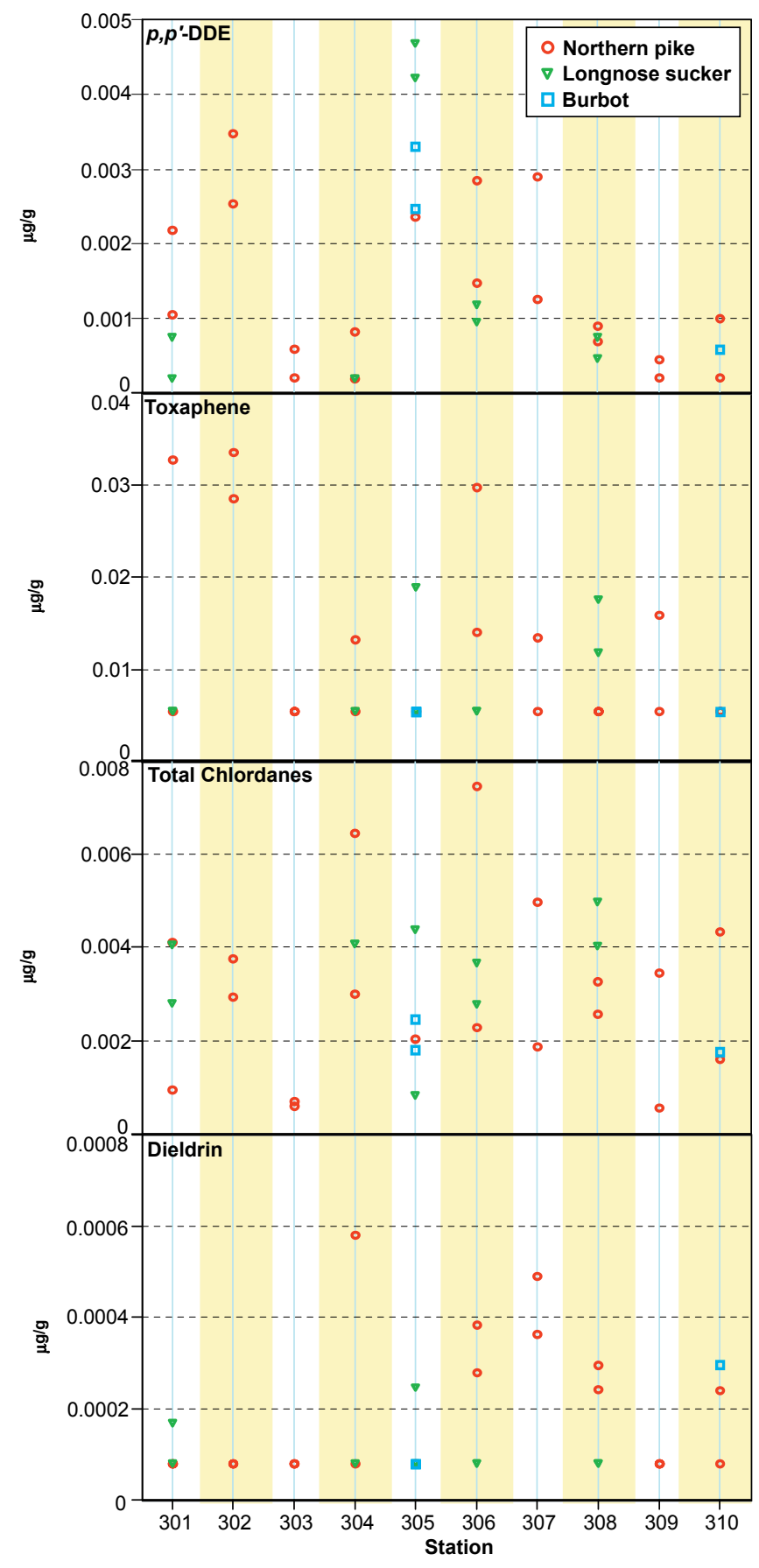

Figure 9. Concentrations ( $\mu \mathrm{g} / \mathrm{g} w w)$ of $p, p^{\prime}-\mathrm{DDE}$, toxaphene, total chlordanes, and dieldrin by station and species in whole body fish composite samples collected in the Yukon River Basin in 2002.

Total chlordanes are the sum of cis- and trans-chlordanes and nonachlors, heptachlor epoxide, and oxychlordane. Censored values are plotted as one-half the LOD. Stations are ordered upstream to downstream. See Table 1 for station descriptions.

down of aldrin, which has not been used in the U.S. since 1974. Concentrations $\geq \operatorname{LOD}(0.0002 \mu \mathrm{g} / \mathrm{g} \mathrm{ww})$ were found in $35 \%$ of the samples from seven sites (Table 11). Concentrations were greatest $(0.001 \mu \mathrm{g} / \mathrm{g} \mathrm{ww})$ in female northern pike from Station 304 (Fig. 9). All geometric station means were
$<0.0004 \mu \mathrm{g} / \mathrm{g}$ ww (Table 12). Historical NCBP concentrations of dieldrin were $\leq \mathrm{LOD}(<0.01 \mu \mathrm{g} / \mathrm{g} \mathrm{ww})$ in northern pike, longnose sucker, and burbot from Station 305 (Schmitt and others, 1999b). Dieldrin was <LOD $(0.01 \mu \mathrm{g} / \mathrm{g} \mathrm{ww})$ in northern pike and burbot samples collected in 1989 from Lake Munchumia located within the YRB (Snyder-Conn, 1992).

Several laboratory studies examined the effects of dieldrin on fish. Whole body concentrations of $0.36-2.13 \mu \mathrm{g} / \mathrm{g}$ ww were determined to have no effect on survival or growth of juvenile rainbow trout (Macek and others, 1970; Shubat and Curtis, 1986 as cited in Jarvinen and Ankley, 1999). Juvenile rainbow trout experience reduced survival at whole body concentrations of $5.65 \mu \mathrm{g} / \mathrm{g}$ ww (Shubat and Curtis, 1986). The YRB concentrations of dieldrin are less than benchmarks set to protect fish and piscivores (Jarvinen and Ankley, 1999; Peakall, 1996).

\section{Endrin}

Endrin is one of the most toxic organochlorine pesticides to fish but was used on comparatively few crops historically (Johnson and Finley, 1980). YRB concentrations of endrin were $<0.001 \mu \mathrm{g} / \mathrm{g}$ ww in all samples (Table 11). Historical NCBP concentrations of endrin were $<$ LOD $(0.005-0.01 \mu \mathrm{g} / \mathrm{g}$ ww) in fish samples from Station 305 (Schmitt and others, $1999 \mathrm{~b})$, and endrin was not detected $(<0.01 \mu \mathrm{g} / \mathrm{g} \mathrm{ww})$ in whole body northern pike or burbot samples in 1989 from Lake Munchumia located within the YRB (Snyder-Conn, 1992). Endrin is not considered a chemical of concern in the YRB.

\section{Other Organochlorine Compounds}

\section{Mirex}

Mirex was used as an insecticide to combat red imported fire ants (Solenopsis wagneri) in the southern U.S. Elsewhere, mirex was used as a flame retardant and as a polymerizing agent (Kaiser, 1987). Consistent with historical NCBP data from 1981 to 1986 (Schmitt and others, 1999b), concentrations of mirex were low $(<0.0003 \mu \mathrm{g} / \mathrm{g} w w)$ in the $2002 \mathrm{YRB}$ samples (Table 11). Snyder-Conn (1992) reported similar findings for mirex in northern pike and burbot from the YRB.

\section{Toxaphene}

Toxaphene was detected $(0.012-0.034 \mu \mathrm{g} / \mathrm{g} \mathrm{ww})$ in multiple northern pike and longnose sucker samples in 2002 (Fig. 9; Table 11), although all geometric station means were $<0.05$ $\mu \mathrm{g} / \mathrm{g}$ ww (Table 12). Toxaphene was the most heavily used insecticide in the U.S. following the ban on DDT (Schmitt and Winger, 1980). Use of toxaphene in the U.S. peaked in the late 1970s, and the pesticide was subsequently banned. Toxaphene has been atmospherically transported to remote 


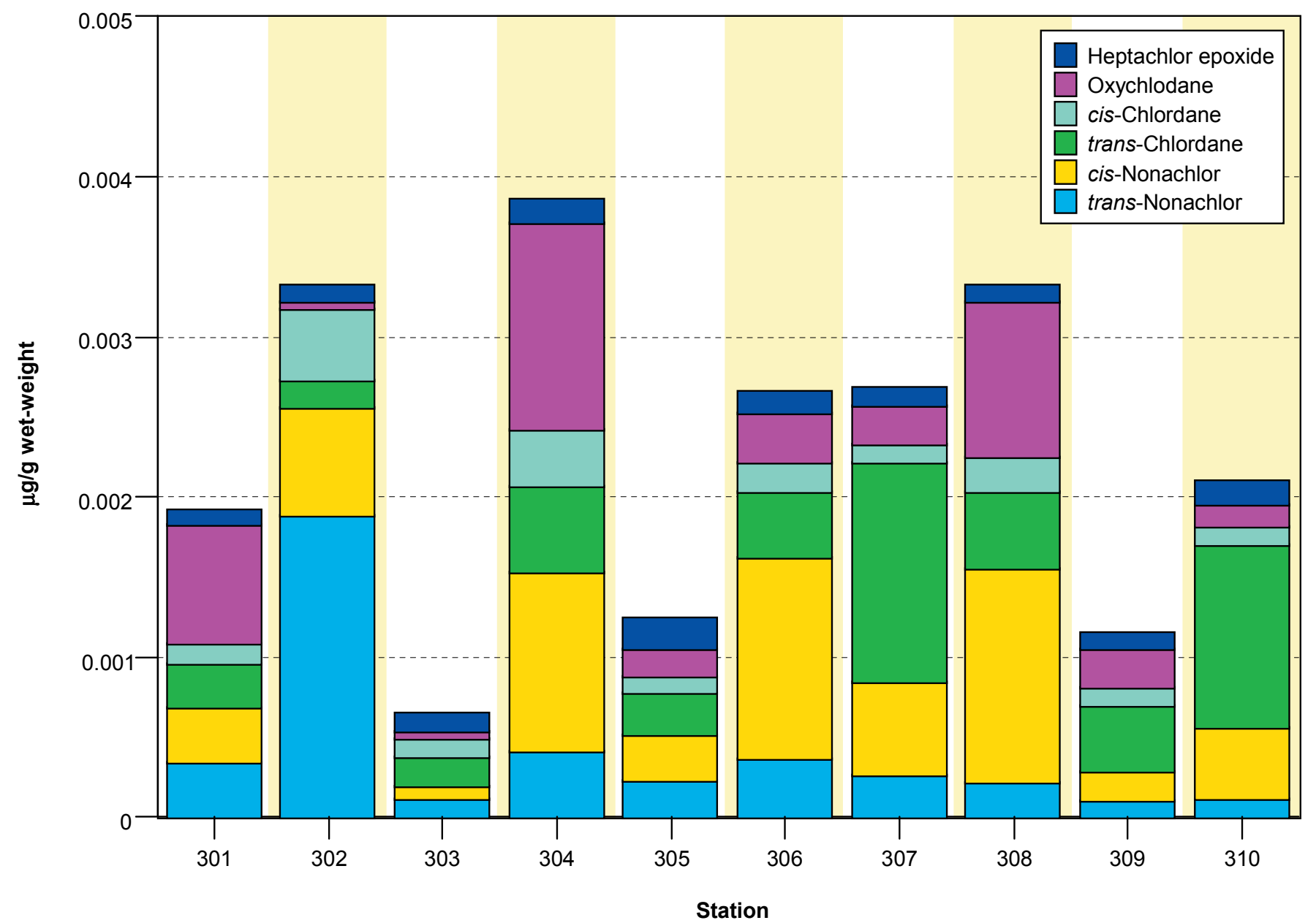

Figure 10. Weighted geometric mean concentrations $(\mu \mathrm{g} / \mathrm{g} \mathrm{ww})$ of chlordane-related compounds (cis- and trans-chlordanes and nonachlors, heptachlor epoxide, and oxychlordane) by station in whole body fish composite samples collected in the Yukon River Basin in 2002. Censored values are represented by one-half the LOD in the computation of means and totals but are not shown in the figure. Stations are ordered upstream to downstream. See Table 1 for station descriptions.

locations, and residues have been detected in fish from the Arctic and the Great Lakes (Muir and others, 1999; Schmitt and others, 1999b). The NCBP program never detected concentrations $(>0.1 \mu \mathrm{g} / \mathrm{g} \mathrm{ww})$ in fish samples near Fairbanks (Schmitt and others, 1999b). Snyder-Conn (1992) reported that northern pike and burbot from a lake within the YRB had concentrations of toxaphene $<$ LOD $(0.05 \mu \mathrm{g} / \mathrm{g} \mathrm{ww})$. Temporal trend analysis is difficult for toxaphene because there are a wide range of LODs from the various studies cited.

Toxaphene has been classified as the major organochlorine contaminant in the Canadian arctic by the NCP (NCP, 2003). Concentrations of toxaphene were 125 times greater in burbot livers collected from Lake Laberge, Yukon Territory, within the YRB than in burbot from other arctic lakes (Braune and others, 1999). Concentrations of toxaphene in liver tend to be greater than in other tissues because of the high lipid content (Braune and others, 1999). High isolated concentrations of toxaphene in fish may exist within the YRB.

Concentrations of toxaphene from the YRB were compared to laboratory toxicity tests and wildlife thresholds.
Acute and chronic effects of toxaphene on freshwater fish have been noted at whole body concentrations $\geq 0.4 \mu \mathrm{g} / \mathrm{g}$ ww (Eisler and Jacknow, 1985; Jarvinen and Ankley, 1999). Jarvinen and Ankley (1999) reviewed multiple laboratory studies on the acute and chronic effects of toxaphene, among these were several by Mayer and others $(1975 ; 1978)$. These authors reported that adult brook trout containing whole body concentrations of $0.4 \mu \mathrm{g} / \mathrm{g}$ ww produced eggs with reduced viability, and lake trout and white sucker containing 0.035-0.203 $\mu \mathrm{g} / \mathrm{g}$ ww also produced eggs with reduced viability (Mayer and others, 1975). Survival and growth of freshwater fish (several species) at various life stages were reduced at concentrations $>0.90 \mu \mathrm{g} / \mathrm{g}$ ww (Mayer and others, 1975; 1978).

\section{Hexachlorocyclohexanes ( $\mathrm{HCH})$}

Four relatively short-lived $\mathrm{HCH}$ isomers $(\alpha-, \beta-, \delta-, \gamma-$ $\mathrm{HCH}$ ) were measured in the 2002 YRB samples. A mixture of $\mathrm{HCH}$ isomers was historically used on cotton and other crops 
in the U.S., but only $\gamma$-HCH (lindane) is still used in North America for some agricultural and domestic applications. All fish samples from the YRB had concentrations $<0.01$ $\mu \mathrm{g} / \mathrm{g}$ ww for these isomers. Concentrations of $\alpha$ - and $\gamma-\mathrm{HCH}$ were $<$ LOD $(0.01 \mu \mathrm{g} / \mathrm{g} \mathrm{ww})$ in fish collected from the NCBP site near Fairbanks from 1977 to 1986 (Schmitt and others, 1999b). These results are consistent with previous data from the YRB (Snyder-Conn, 1992).

\section{Hexachlorobenzene (HCB)}

HCB was produced for use as a fungicide and was a by-product of the production of other chlorinated hydrocarbons. HCB has been considered less toxic to fish than many other persistent organochlorines, although it may contain toxic impurities (Schmitt and others, 1999b). Concentrations of HCB were $<$ LOD $(0.003 \mu \mathrm{g} / \mathrm{g} w w)$ in all samples from the YRB in 2002 and in historical NCBP concentrations (Schmitt and others, 1999b). These finding are similar to those of Snyder-Conn (1992) who reported concentrations of HCB in northern pike and burbot from a lake in the YRB to be $<\mathrm{LOD}$ (0.01 $\mu \mathrm{g} / \mathrm{g} \mathrm{ww})$.

\section{Total PCBs, H4IIE-Derived Dioxin Equivalents, and Ethoxyresorufin 0-Deethylase (EROD) Activity}

\section{Total PCBs}

Total PCBs exceeded the LOD $(0.02 \mu \mathrm{g} / \mathrm{g} \mathrm{ww})$ in 28 of 31 fish samples (90\%) from nine stations (Table 11). Concentrations ranged from 0.02 to $0.09 \mu \mathrm{g} / \mathrm{g}$ ww, with the maximum concentration measured in a female longnose sucker sample from Station 305 (Table 11; Fig. 11). Four of the five greatest concentrations of total PCBs $(\geq 0.05 \mu \mathrm{g} / \mathrm{g} \mathrm{ww})$ were measured in fish from Station 305 (Fig. 11). Geometric station means were $<0.062 \mu \mathrm{g} / \mathrm{g}$ ww in all samples (Table 12).

Data from the YRB in 2002 were compared to other studies measuring concentrations of PCBs in fish. Concentrations of PCBs were lower in 2002 samples compared to historical NCBP concentrations (1969-1986) that measured Aroclor mixtures $(1248,1254,1260)$ from Fairbanks (Schmitt and others, 1999b). Few YRB studies measuring PCBs in whole body samples exist. Whole body concentrations of PCBs in northern pike were $0.09 \mu \mathrm{g} / \mathrm{g}$ ww in lakes in the upper YRB (Braune and others, 1999). These concentrations were similar to 2002 northern pike concentrations. Kidd and others (1998) measured concentrations of PCBs in longnose sucker (0.011$0.013 \mu \mathrm{g} / \mathrm{g} \mathrm{ww})$ and northern pike $(<0.001-0.007 \mu \mathrm{g} / \mathrm{g} \mathrm{ww})$ muscle samples from YRB lakes within the Yukon Territory, Canada. Studies from the NCP (2003) reported concentrations of PCBs in burbot livers increased from 1990 to 1999 in the Canadian arctic. Mueller and Matz (2002) reported concentra-

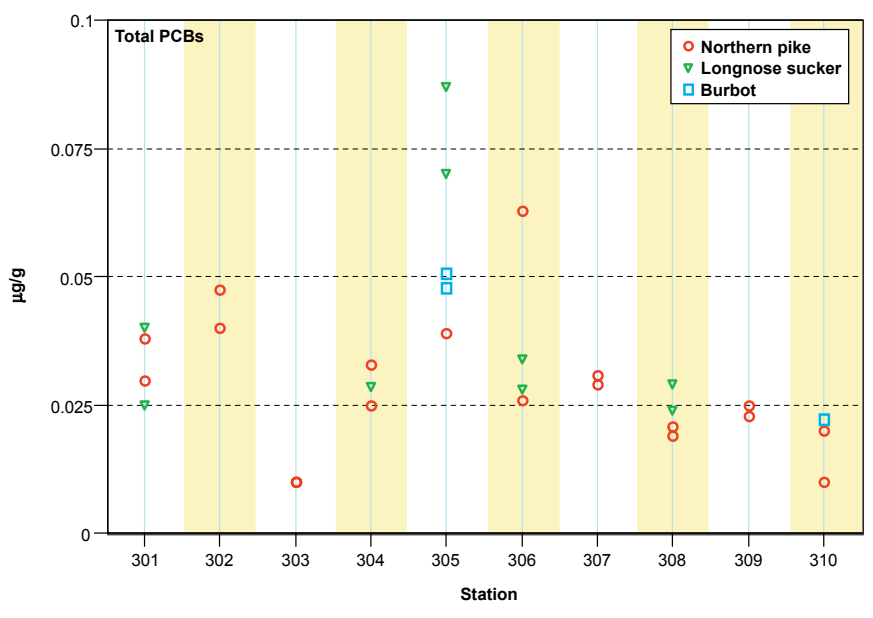

Figure 11. Concentrations of total PCBs ( $\mu \mathrm{g} / \mathrm{g} w w)$ by station and species in whole body fish composite samples collected in the Yukon River Basin in 2002. Censored values are plotted as onehalf the LOD. Stations are ordered upstream to downstream. See Table 1 for station descriptions.

tions of PCBs in burbot livers were $>0.11 \mu \mathrm{g} / \mathrm{g}$ ww in several YRB NWRs, and the greatest concentrations (0.27-1.4 $\mu \mathrm{g} / \mathrm{g}$ ww) were found in burbot samples collected near Fairbanks.

Concentrations of total PCBs from 2002 were compared to laboratory-based toxicity tests and wildlife criteria. Concentrations of PCBs did not exceed the New York State Department of Environmental Conservation (NYSDEC) wildlife guideline for fish $(0.11 \mu \mathrm{g} / \mathrm{g} \mathrm{ww})$ in any YRB fish sample (Fig. 11; Newell and others, 1987). Niimi (1996) as cited in Beyer and others (1996) determined that fish tissue concentrations of $100 \mu \mathrm{g} / \mathrm{g}$ ww can affect reproduction in females or be lethal, and concentrations of $50 \mu \mathrm{g} / \mathrm{g}$ ww can reduce growth and survival in offspring. Mink had inferior reproductive performance and offspring survival when fed Great Lakes fish or fish products with concentrations of PCBs of $0.48 \mu \mathrm{g} / \mathrm{g}$ ww (Hornshaw and others, 1983). Concentrations of PCBs in 2002 YRB fish samples were below these thresholds.

\section{H4IIE Bioassay}

Dioxin-like activities in 31 composite samples were analyzed from 10 YRB stations. All samples had TCDD-EQ $\leq \mathrm{LOD}(1.0 \mathrm{pg} / \mathrm{g})$, which indicates the YRB samples did not have dioxin-like activity. A previous study from the YRB determined dioxins $<$ LOD in northern pike and burbot (Snyder-Conn, 1992).

Previous studies have examined TCDD-EQ levels in wildlife. Most of the TCDD-EQ levels in fish from the YRB are less than those reported in fish from reference sites in previous studies (Giesy and others, 1995; Schmitt and others, 2002a; van den Heuvel and others, 1995). The dietary threshold for toxicity of TCDD is $4.4 \mathrm{pg} / \mathrm{g}$ for mammals (Heaton and others, 1995; Tillitt and others, 1996) and approximately $5 \mathrm{pg} /$ 
$\mathrm{g}$ for avian wildlife (Nosek and others, 1992). YRB samples did not approach $35 \mathrm{pg} / \mathrm{g}$, the threshold for toxic effects in fish (Schmitt and others, 2002a; Walker and others, 1996; Whyte and others, 2004).

\section{Ethoxyresorufin 0-Deethylase (EROD) Activity}

EROD activity can be influenced by numerous factors including species (Addison and others, 1991; Segner and others, 1995), fish size and age (Khan and Payne, 2002a; Peters and Livingstone, 1995; Pluta, 1993), nutrition (Ankley and others, 1989), reproductive status (Campbell and others, 1976; Schreck and Hopwood, 1974), water temperature (Khan and Payne, 2002b; Machala and others, 1997), and capture activity (Machala and others, 1997). EROD activity can also vary among fish species, between genders, and among developmental stages of reproduction (Whyte and others, 2000). An ANOVA model containing the factors station, gender, and gonadal stage was not significant for northern pike or longnose sucker in the YRB (Table 13). Analysis of the entire BEST LRMN data set, which spanned a wider range of EROD values, indicated that gender was significant for most fish species including longnose sucker (BEST Program, unpublished data). Therefore, EROD activity was tabulated and evaluated by gender for northern pike and longnose sucker.

\section{EROD in Northern Pike}

Mean EROD activity in female northern pike was greatest $(8.57 \mathrm{pmol} / \mathrm{min} / \mathrm{mg})$ at Station $301(n=4)$, and EROD activity ranged from 7.1 to $10.2 \mathrm{pmol} / \mathrm{min} / \mathrm{mg}$ in individual fish from this station (Fig. 12; Table 14). All other geometric station means for female northern pike were $<7.8 \mathrm{pmol} / \mathrm{min} / \mathrm{mg}$. A female pike from Station 306 had the maximum EROD activity (20.7 pmol/min $/ \mathrm{mg})$. Previous studies examining EROD activity in northern pike are limited. Williams and others (1997) determined basal EROD activity in female northern pike from western Canada to be $10-30 \mathrm{pmol} / \mathrm{min} / \mathrm{mg}$ (as reviewed by Whyte and others, 2000). EROD activity in female northern pike ranged from 0.6 to $0.9 \mathrm{pmol} / \mathrm{min} / \mathrm{mg}$ in the MRB (Schmitt and others, 2002a) and 0.14 to 1.77 $\mathrm{pmol} / \mathrm{min} / \mathrm{mg}$ in the RGB (Schmitt and others, 2004). Most individual female northern pike (83\%) in the YRB had EROD activities $<10 \mathrm{pmol} / \mathrm{min} / \mathrm{mg}$ in our study.

Mean EROD activity in male northern pike was greatest $(17.5 \mathrm{pmol} / \mathrm{min} / \mathrm{mg})$ at Station $301(n=2)$, with individual EROD values of 11.1-27.6 pmol/min/mg (Fig. 12; Table 14). All other geometric station means for male northern pike were $<10.9 \mathrm{pmol} / \mathrm{min} / \mathrm{mg}$. Few studies have examined EROD activity in northern pike. Male northern pike had EROD activity range from 1.1 to $2.7 \mathrm{pmol} / \mathrm{min} / \mathrm{mg}$ in the MRB (Schmitt and others, 2002a) and 0.18 to $2.30 \mathrm{pmol} / \mathrm{min} / \mathrm{mg}$ in the RGB (Schmitt and others, 2004). EROD activity in male northern pike from western Canada was determined to be $30-45 \mathrm{pmol} /$ $\mathrm{min} / \mathrm{mg}$ (Williams and others, 1997), which is greater than the maximum EROD activity calculated for male northern pike in 2002.

\section{EROD in Longnose Sucker}

Mean EROD activity in female longnose sucker was greatest $(8.78 \mathrm{pmol} / \mathrm{min} / \mathrm{mg})$ at Station 301, and EROD activity ranged from 5.1 to $14.5 \mathrm{pmol} / \mathrm{min} / \mathrm{mg}$ in individual fish from this station (Fig. 12; Table 14). All other geometric station means for female longnose sucker were $<7.1 \mathrm{pmol} /$ $\mathrm{min} / \mathrm{mg}$. Mean EROD activities in male longnose sucker were comparable to females with the greatest $(10.0 \mathrm{pmol} / \mathrm{min} / \mathrm{mg})$ activity measured at Station $301(n=1)$ (Table 14). All other geometric station means for male longnose sucker were $<9.6$ $\mathrm{pmol} / \mathrm{min} / \mathrm{mg}$.

Studies determining basal EROD activities for longnose sucker are limited. Longnose sucker from the YRB had similar EROD activities to female (2.4-11.0 pmol/ $/ \mathrm{min} / \mathrm{mg}$ ) and male (7.3-18.0 $\mathrm{pmol} / \mathrm{min} / \mathrm{mg}$ ) longnose sucker from the CRB (Hinck and others, 2004). Largescale sucker (Catostomus macrocheilus) from the CRB had station means $>15 \mathrm{pmol} /$ $\mathrm{min} / \mathrm{mg}$, which were greater than EROD activities in YRB longnose sucker (Hinck and others, 2004). White sucker and longnose sucker have reported EROD activities ranging from 5 to $15 \mathrm{pmol} / \mathrm{min} / \mathrm{mg}$ (Whyte and others, 2000). EROD activity was measured in white sucker from the Mississippi River near Little Falls, Minnesota (Schmitt and others, 2002a). Activities range from 1.0 to $13.1 \mathrm{pmol} / \mathrm{min} / \mathrm{mg}$ in females and 1.4 to 3.4 $\mathrm{pmol} / \mathrm{min} / \mathrm{mg}$ in males (Schmitt and others, 2002a), which are similar to the EROD rates mesured in YRB longnose sucker. Others studies have reported that EROD activities range from 8.5 to $10 \mathrm{pmol} / \mathrm{min} / \mathrm{mg}$ in white sucker from reference or uncontaminated sites (Coulliard and Hodson, 1996; Schrank and others, 1997). White sucker from a site contaminated by PCBs, PAHs, and heavy metals had a mean EROD activity of $35.2 \mathrm{pmol} / \mathrm{min} / \mathrm{mg}$ (Schrank and others, 1997). Four individual longnose sucker $(<9 \%)$ from Stations 305 and 308 in our study had EROD activities $>15 \mathrm{pmol} / \mathrm{min} / \mathrm{mg}$ (Fig. 12). EROD activities in longnose sucker from the YRB are less than or equal to activities measured in longnose sucker at reference or uncontaminated sites in other studies.

\section{EROD in Burbot}

Hepatic EROD activity was measured in burbot from Stations 305 and 310. Mean station EROD activities in female and male burbot from Station 305 were 1.3 and $7.0 \mathrm{pmol} / \mathrm{min} /$ $\mathrm{mg}$, respectively. One male burbot from Station 310 had an EROD activity of $2.6 \mathrm{pmol} / \mathrm{min} / \mathrm{mg}$. These values are less than EROD activities reported in several Canadian studies (Kloepper-Sams and Benton, 1994; Lockhart and Metner, 1992; Williams and others, 1997) reviewed in Whyte and others (2000) that reported basal EROD activities for burbot to be $>10 \mathrm{pmol} / \mathrm{min} / \mathrm{mg}$. 
Table 13. Results of preliminary analysis of variance investigating the effects of various factors on biomarker responses in northern pike and longnose sucker in the Yukon River Basin in 2002. Shown are degrees-of-freedom (df), $F$-values with levels of significance $\left({ }^{*} 0.01<P \leq 0.05\right.$; $\left.{ }^{* *} P \leq 0.01\right)$, and coefficients of determination $\left(R^{2}\right)$. ${ }^{\text {a }}$ Only female fish include in analysis. ND, not determined.

\begin{tabular}{|c|c|c|c|c|c|c|}
\hline \multirow{2}{*}{$\begin{array}{l}\text { Variable, Source, and } \\
\text { (Transformation) }\end{array}$} & \multicolumn{3}{|c|}{ Northern Pike } & \multicolumn{3}{|c|}{ Longnose Sucker } \\
\hline & df & $F$ & $R^{2}$ & $\mathrm{df}$ & $F$ & $R^{2}$ \\
\hline \multicolumn{7}{|l|}{ EROD $(\log )$} \\
\hline Model & 31 & $3.71 * *$ & 0.49 & 13 & $2.07 *$ & 0.46 \\
\hline Station & 6 & 0.86 & & 3 & 0.71 & \\
\hline Gender & 1 & 0.36 & & 1 & 3.24 & \\
\hline Station*Gender & 5 & 0.80 & & 0 & 1.07 & \\
\hline Stage & 1 & 0.66 & & 1 & 0.06 & \\
\hline Stage*Station & 6 & 0.80 & & 3 & 1.11 & \\
\hline Stage*Gender & 1 & 0.89 & & 1 & 3.95 & \\
\hline Stage*Station*Gender & 5 & 0.70 & & 0 & ND & \\
\hline Error & 122 & & & 31 & & \\
\hline \multicolumn{7}{|l|}{ Condition Factor } \\
\hline Model & 32 & $5.32 * *$ & 0.58 & 13 & $3.69 * *$ & 0.61 \\
\hline Station & 7 & $7.33 * *$ & & 3 & 1.27 & \\
\hline Gender & 1 & 0.61 & & 1 & 3.54 & \\
\hline Station*Gender & 5 & $2.66^{*}$ & & 0 & 0.32 & \\
\hline Stage & 1 & 1.51 & & 1 & 1.13 & \\
\hline Stage*Station & 7 & $3.81 * *$ & & 3 & 2.14 & \\
\hline Stage*Gender & 1 & 1.84 & & 1 & 3.09 & \\
\hline Stage*Station*Gender & 5 & $3.04 *$ & & 0 & $\mathrm{ND}$ & \\
\hline Error & 122 & & & 31 & & \\
\hline \multicolumn{7}{|l|}{ Splenosomatic Index } \\
\hline Model & 18 & $2.24 * *$ & 0.23 & 8 & 1.44 & 0.24 \\
\hline Station & 9 & $2.53 *$ & & 4 & 2.16 & \\
\hline Gender & 1 & $7.81 * *$ & & 1 & 0.10 & \\
\hline Station*Gender & 8 & 1.45 & & 3 & 0.28 & \\
\hline Error & 137 & & & 36 & & \\
\hline \multicolumn{7}{|l|}{ Hepatosomatic Index } \\
\hline Model & 18 & 0.79 & 0.09 & ND & ND & ND \\
\hline Station & 9 & 0.74 & & ND & & \\
\hline Gender & 1 & 0.53 & & ND & & \\
\hline Station*Gender & 8 & 0.80 & & ND & & \\
\hline Error & 136 & & & ND & & \\
\hline \multicolumn{7}{|l|}{ HAI (rank) } \\
\hline Model & 32 & $4.88 * *$ & 0.51 & 13 & 0.68 & 0.24 \\
\hline Station & 7 & $3.91 * *$ & & 3 & 1.16 & \\
\hline Gender & 1 & 1.03 & & 1 & 0.06 & \\
\hline Station*Gender & 5 & 0.86 & & 0 & 1.32 & \\
\hline Stage & 1 & 0.43 & & 1 & 2.00 & \\
\hline Stage*Station & 7 & 0.78 & & 3 & 1.14 & \\
\hline Stage*Gender & 1 & 1.92 & & 1 & 0.38 & \\
\hline Stage*Station $*$ Gender & 5 & 1.26 & & 0 & ND & \\
\hline Error & 121 & & & 28 & & \\
\hline
\end{tabular}


Table 13. Results of preliminary analysis of variance investigating the effects of various factors on biomarker responses in northern pike and longnose sucker in the Yukon River Basin in 2002. Shown c degrees-of-freedom (df), $F$-values with levels of significance $\left({ }^{*} 0.01<P \leq 0.05 ;{ }^{* *} P \leq 0.01\right)$, and coefficien. determination $\left(R^{2}\right)$. ${ }^{\text {a }}$ nly female fish include in analysis. ND, not determined.-Continued

\begin{tabular}{|c|c|c|c|c|c|c|}
\hline \multirow{2}{*}{$\begin{array}{l}\text { Variable, Source, and } \\
\text { (Transformation) }\end{array}$} & \multicolumn{3}{|c|}{ Northern Pike } & \multicolumn{3}{|c|}{ Longnose Sucker } \\
\hline & $\mathrm{df}$ & $F$ & $R^{2}$ & df & $F$ & $R^{2}$ \\
\hline \multicolumn{7}{|l|}{ MA-\% $(\log )$} \\
\hline Model & 37 & 1.13 & 0.48 & 14 & 1.13 & 0.35 \\
\hline Station & 9 & 0.06 & & 4 & 0.96 & \\
\hline Gender & 1 & 1.15 & & 1 & 0.22 & \\
\hline Station*Gender & 8 & $6.36^{*}$ & & 0 & ND & \\
\hline Age & 1 & 0.91 & & 1 & 0.00 & \\
\hline Age*Station & 9 & 0.08 & & 4 & 0.58 & \\
\hline Age*Gender & 1 & 1.02 & & 1 & 0.34 & \\
\hline Age*Station*Gender & 8 & & & 0 & ND & \\
\hline Error & 100 & & & 29 & & \\
\hline \multicolumn{7}{|l|}{ MA-size (log) } \\
\hline Model & 37 & $1.79 *$ & 0.40 & 14 & 1.61 & 0.44 \\
\hline Station & 9 & 0.52 & & 4 & 1.42 & \\
\hline Gender & 1 & 0.79 & & 1 & 1.24 & \\
\hline Station*Gender & 8 & 0.57 & & 0 & ND & \\
\hline Age & 1 & 1.86 & & 1 & 0.17 & \\
\hline Age*Station & 9 & 0.47 & & 4 & 1.07 & \\
\hline Age*Gender & 1 & 0.65 & & 1 & 1.27 & \\
\hline Age*Station*Gender & 8 & 0.40 & & 0 & ND & \\
\hline Error & 100 & & & 29 & & \\
\hline \multicolumn{7}{|l|}{ MA-\# } \\
\hline Model & 37 & $1.55^{*}$ & 0.36 & 14 & 1.50 & 0.42 \\
\hline Station & 9 & 1.40 & & 4 & $3.12 *$ & \\
\hline Gender & 1 & 0.01 & & 1 & 0.04 & \\
\hline Station*Gender & 8 & 0.65 & & 0 & ND & \\
\hline Age & 1 & 1.68 & & 1 & 2.03 & \\
\hline Age*Station & 9 & 0.66 & & 4 & 0.60 & \\
\hline Age*Gender & 1 & 0.31 & & 1 & 0.00 & \\
\hline Age*Station*Gender & 8 & 0.56 & & 0 & $\mathrm{ND}$ & \\
\hline Error & 100 & & & & & \\
\hline \multicolumn{7}{|l|}{ Gonadosomatic Index } \\
\hline Model & 32 & $26.8 * *$ & 0.88 & 13 & $2.31 *$ & 0.49 \\
\hline Station & 7 & 0.33 & & 3 & 0.20 & \\
\hline Gender & 1 & 0.07 & & 1 & 0.15 & \\
\hline Station*Gender & 5 & 0.10 & & 0 & 0.32 & \\
\hline Stage & 1 & 0.97 & & 1 & 0.45 & \\
\hline Stage* Station & 7 & 1.46 & & 3 & 0.17 & \\
\hline Stage*Gender & 1 & 0.29 & & 1 & 0.05 & \\
\hline Stage*Station $*$ Gender & 5 & 0.09 & & 0 & ND & \\
\hline Error & 122 & & & 31 & & \\
\hline
\end{tabular}


Table 13. Results of preliminary analysis of variance investigating the effects of various factors on biomarker responses in northern pike and longnose sucker in the Yukon River Basin in 2002. Shown degrees-of-freedom (df), $F$-values with levels of significance $\left({ }^{*} 0.01<P \leq 0.05 ;{ }^{* *} P \leq 0.01\right)$, and coefficien determination $\left(R^{2}\right)$. ${ }^{a}$ Only female fish include in analysis. ND, not determined.-Continued

\begin{tabular}{|c|c|c|c|c|c|c|}
\hline \multirow{2}{*}{$\begin{array}{l}\text { Variable, Source, and } \\
\text { (Transformation) }\end{array}$} & \multicolumn{3}{|c|}{ Northern Pike } & \multicolumn{3}{|c|}{ Longnose Sucker } \\
\hline & $\mathrm{df}$ & $F$ & $R^{2}$ & $\mathrm{df}$ & $F$ & $R^{2}$ \\
\hline \multicolumn{7}{|l|}{ Vitellogenin $(\log )$} \\
\hline Model & 28 & $6.85 * *$ & 0.65 & 13 & $7.28 * *$ & 0.76 \\
\hline Station & 5 & 0.64 & & 3 & 0.72 & \\
\hline Gender & 1 & 0.22 & & 1 & 0.71 & \\
\hline Station*Gender & 4 & 0.89 & & 0 & 1.53 & \\
\hline Stage & 1 & 1.77 & & 1 & 2.57 & \\
\hline Stage*Station & 6 & 0.32 & & 3 & 0.28 & \\
\hline Stage*Gender & 1 & 1.30 & & 1 & 0.02 & \\
\hline Stage*Station*Gender & 4 & 1.59 & & 0 & ND & \\
\hline Error & 105 & & & 31 & & \\
\hline \multicolumn{7}{|l|}{ Estradiol } \\
\hline Model & 28 & $3.31 * *$ & 0.47 & 13 & $3.54 * *$ & 0.60 \\
\hline Station & 5 & 0.51 & & 3 & 1.85 & \\
\hline Gender & 1 & 0.04 & & 1 & $6.49^{*}$ & \\
\hline Station*Gender & 4 & 1.72 & & 0 & 1.86 & \\
\hline Stage & 1 & 2.08 & & 1 & $9.16^{*}$ & \\
\hline Stage*Station & 5 & 0.24 & & 3 & 1.82 & \\
\hline Stage*Gender & 1 & 0.16 & & 1 & 0.12 & \\
\hline Stage*Station*Gender & 4 & 1.46 & & 0 & ND & \\
\hline Error & 103 & & & 31 & & \\
\hline \multicolumn{7}{|l|}{ 11-ketotestosterone } \\
\hline Model & 28 & $4.03 * *$ & 0.52 & 13 & 1.50 & 0.39 \\
\hline Station & 5 & $3.38 * *$ & & 3 & 1.10 & \\
\hline Gender & 1 & $5.52 *$ & & 1 & 2.30 & \\
\hline Station*Gender & 4 & 2.04 & & 0 & 0.10 & \\
\hline Stage & 1 & $6.15^{*}$ & & 1 & 2.17 & \\
\hline Stage*Station & 5 & 2.84 & & 3 & 0.80 & \\
\hline Stage*Gender & 1 & 1.66 & & 1 & 0.06 & \\
\hline Stage*Station*Gender & 4 & 1.31 & & 0 & ND & \\
\hline Error & 103 & & & 31 & & \\
\hline \multicolumn{7}{|c|}{ Estradiol/11-ketotestosterone } \\
\hline Model & 28 & $1.71^{*}$ & 0.32 & 13 & $2.28^{*}$ & 0.49 \\
\hline Station & 5 & 0.54 & & 3 & 2.71 & \\
\hline Gender & 1 & 0.86 & & 1 & $9.68 * *$ & \\
\hline Station*Gender & 4 & 0.76 & & 0 & 1.19 & \\
\hline Stage & 1 & 1.91 & & 1 & $7.58 * *$ & \\
\hline Stage*Station & 5 & 0.71 & & 3 & 2.29 & \\
\hline Stage*Gender & 1 & 0.23 & & 1 & 1.13 & \\
\hline Stage*Station*Gender & 4 & 0.91 & & 0 & ND & \\
\hline Error & 103 & & & 31 & & \\
\hline
\end{tabular}


Table 13. Results of preliminary analysis of variance investigating the effects of various factors on biomarker responses in northern pike and longnose sucker in the Yukon River Basin in 2002. Shown are degrees-of-freedom (df), $F$-values with levels of significance $\left({ }^{*} 0.01<P \leq 0.05 ;{ }^{* *} P \leq 0.01\right)$, and coefficients of determination $\left(R^{2}\right)$. a Only female fish include in analysis. ND, not determined.-Continued

\begin{tabular}{|c|c|c|c|c|c|c|}
\hline \multirow{2}{*}{$\begin{array}{l}\text { Variable, Source, and } \\
\text { (Transformation) }\end{array}$} & \multicolumn{3}{|c|}{ Northern Pike } & \multicolumn{3}{|c|}{ Longnose Sucker } \\
\hline & df & $F$ & $R^{2}$ & $\mathrm{df}$ & $F$ & $R^{2}$ \\
\hline \multicolumn{7}{|l|}{ Atresia $^{a}$} \\
\hline Model & 30 & 1.21 & 0.44 & 13 & 0.46 & 0.26 \\
\hline Station & 3 & 0.48 & & 0 & ND & \\
\hline Stage & 1 & 0.14 & & 1 & 0.00 & \\
\hline Stage*Station & 3 & 0.04 & & 0 & ND & \\
\hline Age & 1 & 0.11 & & 1 & 0.00 & \\
\hline Age*Station & 3 & 0.50 & & 0 & ND & \\
\hline Stage*Age & 1 & 0.01 & & 1 & 0.00 & \\
\hline Stage*Age*Station & 3 & 0.18 & & 0 & ND & \\
\hline Error & 46 & & & 17 & & \\
\hline
\end{tabular}

\section{Accumulative Contaminants, H4IIE, and EROD: Summary}

Concentrations of all contaminants except $\mathrm{Hg}$ and $\mathrm{Se}$ measured in YRB fish samples were low. Concentrations of $\mathrm{Hg}$ were $>0.3 \mu \mathrm{g} / \mathrm{g}$ ww in northern pike from Stations 304, 306, 307, and 308 and in burbot from Station 305. Concentrations of $\mathrm{Hg}>0.3 \mu \mathrm{g} / \mathrm{g}$ ww in fish have been shown to cause reproductive impairment in loons (Barr, 1986). Fish from Stations 301, 302, 304, and 305 had concentrations of Se $>0.6$ $\mu \mathrm{g} / \mathrm{g}$ ww, which may be toxic to piscivorous wildlife (Lemly, 1996). Other inorganic and organic chemicals were either $<$ LOD or below wildlife or other threshold criteria. Comparison of 2002 concentrations with historical NCBP data revealed that most organochlorine and elemental contaminants were decreasing, continuing a two-decade trend for accumulative contaminants in the YRB. Dioxin-like contaminants, as indicated by the H4IIE rat hepatoma cell bioassay, were $\leq$ LOD in YRB fish samples. The results are consistent with previous dioxin studies in the basin.

EROD results were not consistent with H4IIE results, indicating fish were exposed to EROD-inducing chemicals other than PCBs and dioxins. Results of the EROD assay determined that northern pike and longnose sucker from Station 301 had the greatest EROD activities compared to other stations, although these activities were less than basal rates estimated from other studies for these species. EROD data for burbot were limited to a small number of individuals, but these values were similar to EROD activities measured in this species from other reference studies. EROD activities in northern pike, longnose sucker, and burbot did not indicate exposure to PAHs or PHHs.

\section{Fish Health Indicators}

\author{
Organism-Level Indicators
}

\section{External Gross Lesions}

External gross abnormalities were identified in the field during the fish health examination (Schmitt and Dethloff, 2000). The fish health assessment determined that $45 \%$ of all fish collected from the YRB had external gross lesions (abnormalities) (Table 15). These lesions were categorized by location including the body surface, eyes, opercles, and fins. The percentage of fish with external lesions ranged from 23\% at Station 309 to $91 \%$ at Station 303 (Table 15). Statistical analyses determined that male and female northern pike, longnose sucker, and burbot did not differ significantly in the occurrence of external lesions; therefore, genders were combined. The percentage of burbot with lesions $(<8 \%)$ was less than the basinwide percentage for all species, although there were fewer burbot collected than northern pike or longnose sucker. The basinwide percentage of northern pike (51\%) and longnose sucker $(41 \%)$ with lesions were comparable. The percent of lesions was high (>50\%) in fish at some stations, but caution needs to be used when interpreting these data. Most lesions were attributed to cuts or abrasions on the body surface of the fish, which are frequently observed in predatory fish like northern pike. Many of these were not considered to be a result of exposure to environmental contaminants but were more likely due to collection and holding time prior to fish processing or normal wear as the fish ages. Pieces of tissue from lip or body lesions of northern pike $(n=6)$ and longnose sucker $(n=1)$ were examined histologically. These lesions were composed of dermal, subdermal, and intramus- 


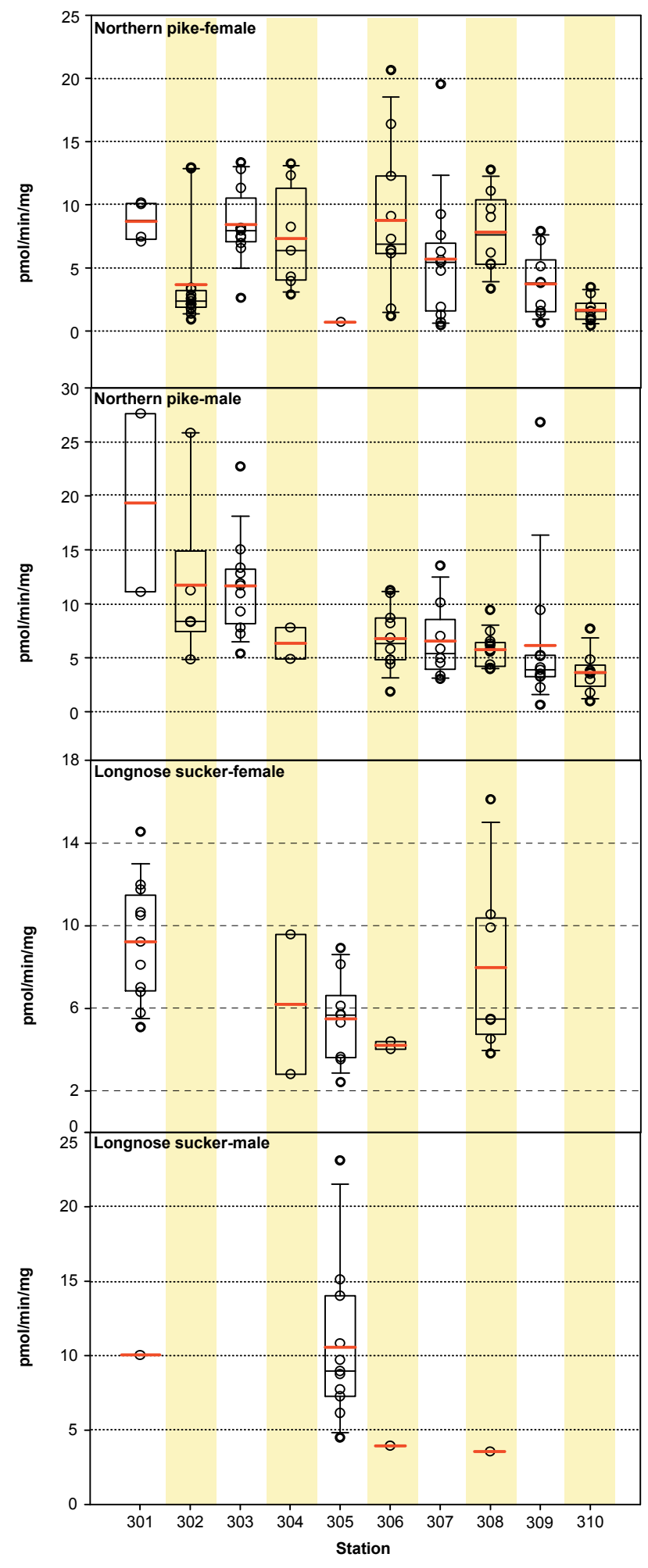

Figure 12. Hepatic microsomal EROD activity $(\mathrm{pmol} / \mathrm{min} / \mathrm{mg}$ ) by station in female and male northern pike and longnose sucker collected in the Yukon River Basin in 2002. Shown for each group are points representing individual fish and the mean (red horizontal line), median (black horizontal line), interquartile range (box), and the 10th and 90th percentiles (whiskers). Stations are ordered upstream to downstream. See Table 1 for station descriptions. cular chronic inflammatory infiltrates for which an eliciting agent was not observed. White nodules on the fins of another longnose sucker were determined to be areas of hypertrophy and hyperplasia of epidermal cells.

\section{Health Assessment Index}

The health assessment index (HAI) is a systematic method used to identify external and internal abnormalities for individual fish during the field health assessment. A higher HAI score indicates a greater number of lesions were identified on the fish. The HAI may vary depending on gender and gonadal stage of development. Neither gender nor gonadal stage influenced HAI in northern pike or longnose sucker (Table 13). Therefore, the HAI scores for both genders were combined for analysis.

HAI scores were evaluated for 156 northern pike from the YRB. Most HAI scores for northern pike (80\%) ranged from 0 to 70 (Table 16). Mean HAI scores in northern pike ranged from 10 to 67 for all stations except Station 303, which had a mean HAI of 92.3 in northern pike (Table 16). Stations 304, 306, and 307 also had multiple fish with HAI scores $>100$ with most lesions attributed to abnormalities of the liver, kidney, gill, and fins. HAI scores for northern pike from Garrison Dam, North Dakota in the MRB ranged from 0-60 (Schmitt and others, 2002a), and those from Alamosa, Colorado in the RGB ranged from 40-110 (Schmitt and others, 2004). Other studies evaluating HAI scores in northern pike were not found.

HAI scores were evaluated in 43 longnose sucker and were consistent among YRB stations. Most HAI scores for longnose sucker (79\%) ranged from 0 to 50 , indicating most longnose sucker were identified as having zero to two gross lesions (Table 16). Station means of HAI scores in longnose sucker ranged from 29 to 36 with the exception of Station 304 (70). All HAI scores in longnose sucker from the YRB were $\leq 100$. HAI values from the YRB generally were $<$ HAI values for longnose and largescale sucker from the CRB (Hinck and others, 2004; Tetra Tech Inc., 1996). Other studies evaluating HAI in longnose sucker were not found.

\section{Condition and Organosomatic Indices}

These indices are considered general indicators of the overall health of the fish, and alterations of these indices may indicate the effects resulting from exposure to contaminants (Schmitt and Dethloff, 2000). Factors such as gender or gonadal stage can affect these indices.

\section{Condition and Organosomatic Indices in Northern Pike}

Station and gender influenced splenosomatic index (SSI) and condition factor (CF) but not hepatosomatic index (HSI) in northern pike (Table 13). Interactions between 
Table 14. Geometric mean and range of microsomal EROD activities ( $\mathrm{pmol} / \mathrm{min} / \mathrm{mg}$ protein) in fish collected in the Yukon River Basin in 2002. Censored values were represented by one half the LOQ in the computation of geometric means. Fish in which gender was undetermined or no gonad was obtained are listed as juvenile. The maximum geometric station mean is shown in bold for each taxon. Stations are listed upstream to downstream.

\begin{tabular}{|c|c|c|c|c|c|c|c|c|c|}
\hline \multirow{2}{*}{ Species and Station } & \multicolumn{3}{|c|}{ Female } & \multicolumn{3}{|c|}{ Male } & \multicolumn{3}{|c|}{ Juvenile } \\
\hline & $n$ & Range & Mean & $n$ & Range & Mean & $n$ & Range & Mean \\
\hline Charley-Kandik, AK (301) & 4 & $7.07-10.2$ & 8.57 & 2 & $11.1-27.6$ & 17.51 & 0 & -- & -- \\
\hline Fort Yukon, AK (303) & 11 & $2.60-13.4$ & 7.82 & 11 & $5.39-22.7$ & 10.87 & 0 & -- & -- \\
\hline The Bridge, AK (304) & 7 & $2.88-13.3$ & 6.36 & 2 & $4.88-7.80$ & 6.17 & 0 & -- & -- \\
\hline Fairbanks, AK (305) & 3 & $0.71-0.71$ & 0.71 & 0 & -- & -- & 1 & -- & 3.50 \\
\hline Galena, AK (308) & 8 & $3.35-12.8$ & 7.19 & 12 & $3.93-9.42$ & 5.58 & 0 & -- & -- \\
\hline Innoko, AK (309) & 9 & $0.64-7.9$ & 2.84 & 11 & $0.64-26.8$ & 4.12 & 0 & -- & -- \\
\hline Kotlik, AK (310) & 9 & $0.42-3.5$ & 1.38 & 8 & $0.96-7.69$ & 3.13 & 0 & -- & -- \\
\hline \multicolumn{10}{|l|}{ Longnose sucker } \\
\hline Charley-Kandik, AK (301) & 11 & $5.09-14.5$ & 8.78 & 1 & -- & 10.03 & 0 & -- & -- \\
\hline The Bridge, AK (304) & 2 & $2.82-9.58$ & 5.19 & 0 & -- & -- & 0 & -- & -- \\
\hline Fairbanks, AK (305) & 8 & $0.23-9.93$ & 1.27 & 4 & $3.06-19.1$ & 7.03 & 0 & -- & -- \\
\hline Kotlik, AK (310) & 0 & -- & -- & 1 & -- & 2.55 & 0 & -- & -- \\
\hline
\end{tabular}

gender and station and stage and station were significant, but neither variable was significant alone. Therefore, data for male and female northern pike were examined separately only for SSI so as not to confound the potential effects other variables may have on the fish health indicators with the effects caused by gender or stage. The basinwide mean CF in northern pike was 0.59 , and station means ranged from 0.51 at Station 303 to 0.67 at Station 307 (Table 17; Fig. 13). Condition factor for all individual northern pike from the YRB was $<0.78$. Similar CF were reported in northern pike from the MRB (Blazer and others, 2002) and RGB (Schmitt and others, 2004). Other studies evaluating $C F$ in northern pike were not found.

Northern pike have discrete livers, unlike longnose sucker, and therefore HSI was calculated. The basinwide mean HSI for northern pike was 1.8\% (Table 17). Station means for HSI in northern pike ranged from $1.1 \%$ at Station 309 to $3.3 \%$ at Station 310 (Table 17; Fig. 13). All stations except Station 310 had mean HSI $<2.2 \%$. HSI $>3.0 \%$ were calculated for fish at Stations 306, 307, and 310; however, most northern pike (81\%) had HSI between 0.7 and $2.5 \%$ (Fig. 13). Station 310 was the only station that consistently had fish with HSI $>2.5 \%$. HSI for individual northern pike from the YRB were greater than those calculated in northern pike from the MRB (1.7-2.8\%; Blazer and others, 2002) and RGB (0.72.6\%; Schmitt and others, 2004). HSI data for northern pike from other studies were not found.

SSI in male and female northern pike were examined separately. The basinwide mean for SSI in female northern pike was $0.11 \%$, and station means ranged from $0.09 \%$ at Station 309 to $0.14 \%$ at Station 306 (Table 18; Fig. 13). SSI station means for female northern pike were greatest at Stations 306, 308 , and 310 , as indicated by the station being a significant factor in the ANOVA model (Table 13). Most female northern pike $(94 \%)$ had SSI between 0.05 and $0.10 \%$. In previous studies, female northern pike from the MRB $(0.09-0.11 \%$; Blazer and others, 2002) and RGB (0.08-0.26\%; Schmitt and others, 2004) had similar SSI to those measured in the YRB.

SSI in male northern pike was greater than in female northern pike with a basinwide mean of $0.13 \%$, and station means ranged from $0.10 \%$ at Station 303 to $0.18 \%$ at Station 301 (Table 18; Fig. 13). SSI in male northern pike ( $\mathrm{SE}=0.007)$ varied more than in female northern pike ( $\mathrm{SE}=0.004)$, with individual SSI values ranging from 0.04 to $0.29 \%$ (Table 18). Most male northern pike ( $85 \%$ ) had SSI between 0.06 to $0.20 \%$. Male northern pike from the MRB $(0.11-0.24 \%$; Blazer and others, 2002) and RGB (0.08-0.24\%; Schmitt and others, 2004) had similar SSI to those measured in the YRB.

\section{Condition and Organosomatic Indices in Longnose Sucker}

Neither gender nor developmental stage influenced fish health indicators in longnose sucker (Table 13). Therefore, the data were combined for statistical analysis.

Condition factor in longnose sucker was generally greater than in northern pike in the YRB. The basinwide mean for $\mathrm{CF}$ in longnose sucker was 0.81 (Table 17). Longnose sucker from Station 308 had the greatest mean CF (0.94), and other station means ranged from 0.76 to 0.86 (Table 17). The CF values did not differ significantly among stations (Table 13). Individual fish $\mathrm{CF}$ values ranged from 0.63 to 1.10 with $78 \%$ 
Table 15. Number and location of external lesions identified on fish collected in the Yukon River Basin in 2002. Body, eyes, opercles, and fins of each fish were examined for the presence of lesions, and the proportion of fish with lesions was calculated. Stations are listed upstream to downstream.

\begin{tabular}{|c|c|c|c|c|c|c|c|}
\hline \multirow[b]{2}{*}{ Station and Species } & \multicolumn{7}{|c|}{ Lesion Location } \\
\hline & $n$ & Body & Eyes & Opercles & Fins & $\begin{array}{c}\text { Total no. } \\
\text { w/lesions }\end{array}$ & Proportion \\
\hline \multicolumn{8}{|c|}{ Charley-Kandik, AK (301) } \\
\hline All & 18 & 8 & 0 & 1 & 0 & 8 & 0.444 \\
\hline Northern pike & 6 & 4 & 0 & 1 & 0 & 4 & 0.667 \\
\hline Longnose sucker & 12 & 4 & 0 & 0 & 0 & 4 & 0.333 \\
\hline \multicolumn{8}{|c|}{ Fish Hook Bend, AK (302) } \\
\hline All & 20 & 7 & 0 & 0 & 0 & 7 & 0.350 \\
\hline Northern pike & 20 & 7 & 0 & 0 & 0 & 7 & 0.350 \\
\hline \multicolumn{8}{|l|}{ Fort Yukon, AK (303) } \\
\hline All & 22 & 13 & 3 & 6 & 11 & 20 & 0.909 \\
\hline Northern pike & 22 & 13 & 3 & 6 & 11 & 20 & 0.909 \\
\hline \multicolumn{8}{|l|}{ The Bridge, AK (304) } \\
\hline All & 11 & 4 & 0 & 5 & 0 & 8 & 0.727 \\
\hline Northern pike & 9 & 3 & 0 & 4 & 0 & 6 & 0.667 \\
\hline Longnose sucker & 2 & 1 & 0 & 1 & 0 & 2 & 1.000 \\
\hline \multicolumn{8}{|l|}{ Fairbanks, AK (305) } \\
\hline All & 36 & 8 & 1 & 4 & 0 & 11 & 0.306 \\
\hline Northern pike & 3 & 1 & 0 & 0 & 0 & 1 & 0.333 \\
\hline Longnose sucker & 21 & 6 & 1 & 4 & 0 & 9 & 0.429 \\
\hline Burbot & 12 & 1 & 0 & 0 & 0 & 1 & 0.083 \\
\hline \multicolumn{8}{|l|}{ Tolovana, AK (306) } \\
\hline All & 23 & 4 & 0 & 3 & 0 & 7 & 0.304 \\
\hline Northern pike & 20 & 4 & 0 & 1 & 0 & 5 & 0.250 \\
\hline Longnose sucker & 3 & 0 & 0 & 2 & 0 & 2 & 0.667 \\
\hline \multicolumn{8}{|l|}{ Tanana, AK (307) } \\
\hline All & 20 & 13 & 1 & 0 & 0 & 13 & 0.650 \\
\hline Northern pike & 20 & 13 & 1 & 0 & 0 & 13 & 0.650 \\
\hline \multicolumn{8}{|l|}{ Galena, AK (308) } \\
\hline All & 28 & 9 & 0 & 2 & 0 & 11 & 0.393 \\
\hline Northern pike & 20 & 7 & 0 & 2 & 0 & 9 & 0.450 \\
\hline Longnose sucker & 8 & 2 & 0 & 0 & 0 & 2 & 0.250 \\
\hline \multicolumn{8}{|l|}{ Innoko, AK (309) } \\
\hline All & 21 & 4 & 0 & 2 & 0 & 5 & 0.238 \\
\hline Northern pike & 21 & 4 & 0 & 2 & 0 & 5 & 0.238 \\
\hline \multicolumn{8}{|l|}{ Kotlik, AK (310) } \\
\hline All & 18 & 8 & 0 & 0 & 4 & 11 & 0.611 \\
\hline Northern pike & 17 & 8 & 0 & 0 & 4 & 11 & 0.647 \\
\hline Burbot & 1 & 0 & 0 & 0 & 0 & 0 & 0.000 \\
\hline \multicolumn{8}{|l|}{ Basin Total } \\
\hline All & 217 & 78 & 5 & 23 & 15 & 101 & 0.465 \\
\hline Northern pike & 158 & 64 & 4 & 16 & 15 & 81 & 0.513 \\
\hline Longnose sucker & 46 & 13 & 1 & 7 & 0 & 19 & 0.413 \\
\hline Burbot & 13 & 1 & 0 & 0 & 0 & 1 & 0.077 \\
\hline
\end{tabular}

of longnose sucker having a CF between 0.70 and 0.90 (Fig. 14). Condition factor in individual longnose sucker from the upper CRB ranged from 0.90 to 1.11 (Hinck and others, 2004). The CF in largescale sucker from the CRB had station means that ranged from 0.86 to 1.2 and a basinwide mean of 0.94 (Hinck and others, 2004). Longnose sucker collected from rivers in northern Alberta had CF ranging from 1.01 to 1.32 (Oakes and others, 2004). Oakes and others (2004) also determined longnose sucker collected below municipal sewage and pulp mill effluents in the Wapiti River had significantly higher $\mathrm{CF}$ compared to upstream reference sites. The state of Minnesota set standards that considered white sucker with $\mathrm{CF}$ $<1.0$ to be in poor condition (Carlander, 1969).

SSI values in longnose sucker were greater than those measured in northern pike from the YRB. Mean SSI values in longnose sucker were similar among YRB stations although some individual values caused increased variability in the data. The basinwide mean SSI for longnose sucker was $0.24 \%$, and the station means for longnose sucker ranged from $0.12 \%$ at Station 306 to $0.27 \%$ at Station 305 (Table 18). The majority 


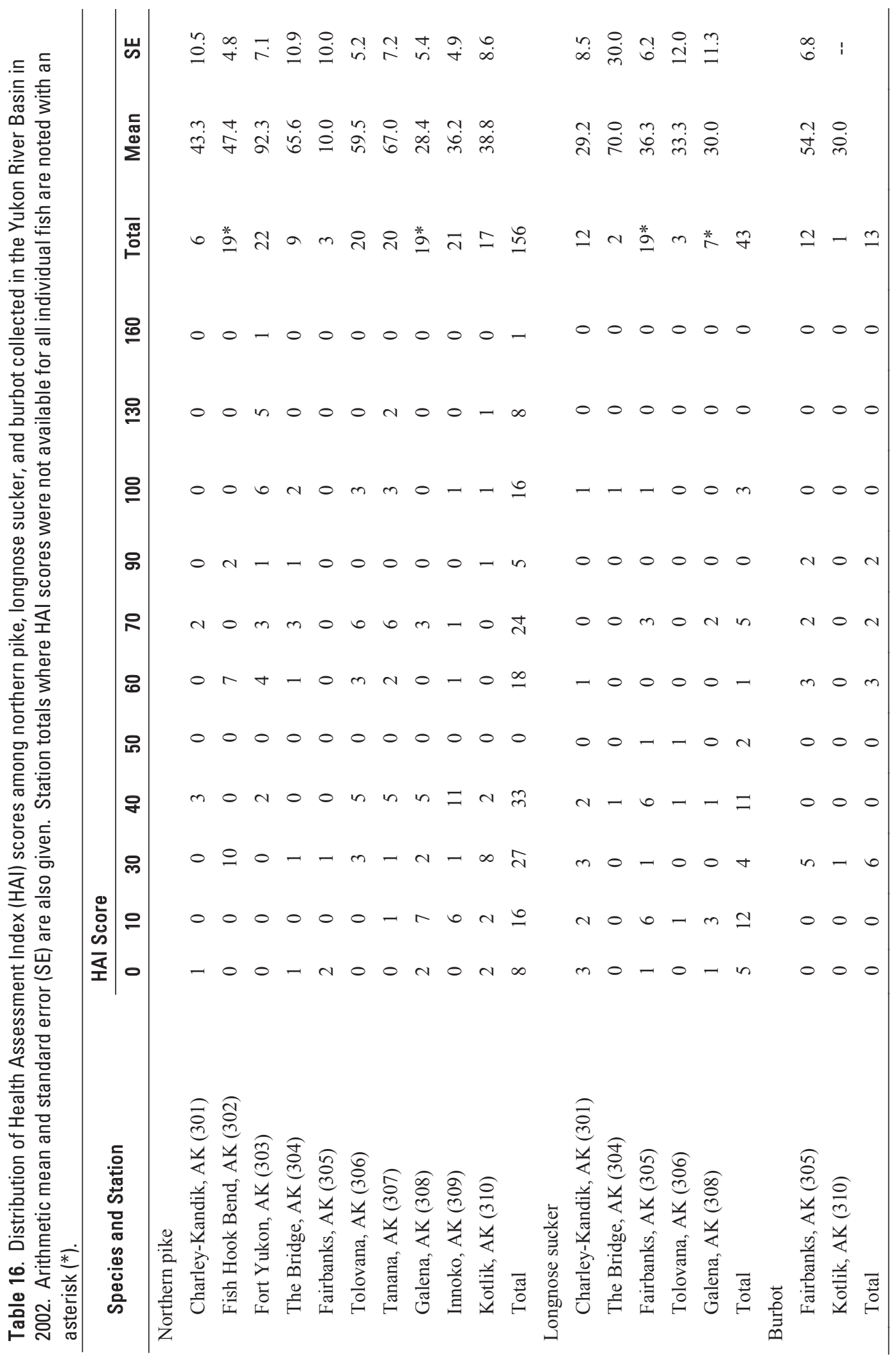


Table 17. Arithmetic mean of condition factor (CF) and hepatosomatic index ( $\mathrm{HSI} ; \%)$ by species and station in northern pike, longnose sucker, and burbot collected int he Yukon River Basin in 2002. Number of samples $(n)$, minimum (min.), maximum (max.), and standard error (SE) are also given. Stations are ordered upstream to downstream. The maximum station mean for each taxon is shown in bold.

\begin{tabular}{|c|c|c|c|c|c|c|c|c|c|c|}
\hline \multirow{2}{*}{ Species and Station } & \multicolumn{5}{|c|}{ Condition Factor (CF) } & \multicolumn{5}{|c|}{ Hepatosomatic Index (HSI) } \\
\hline & $n$ & Mean & Min. & Max. & SE & $n$ & Mean & Min. & Max. & SE \\
\hline \multicolumn{11}{|l|}{ Northern pike } \\
\hline Basin Total & 157 & 0.59 & 0.40 & 0.78 & 0.01 & 156 & 1.78 & 0.63 & 4.76 & 0.06 \\
\hline Charley-Kandik, AK (301) & 6 & 0.57 & 0.51 & 0.70 & 0.03 & 6 & 1.43 & 0.94 & 1.82 & 0.16 \\
\hline Fish Hook Bend, AK (302) & 20 & 0.55 & 0.49 & 0.67 & 0.01 & 18 & 1.19 & 0.90 & 2.43 & 0.08 \\
\hline Fort Yukon, AK (303) & 22 & 0.51 & 0.45 & 0.54 & 0.01 & 22 & 1.25 & 0.90 & 1.96 & 0.06 \\
\hline The Bridge, AK (304) & 9 & 0.57 & 0.40 & 0.66 & 0.03 & 9 & 1.99 & 1.12 & 2.68 & 0.19 \\
\hline Fairbanks, AK (305) & 3 & 0.57 & 0.44 & 0.71 & 0.08 & 3 & 1.94 & 1.50 & 2.40 & 0.26 \\
\hline Tolovana, AK (306) & 20 & 0.60 & 0.48 & 0.69 & 0.01 & 20 & 1.77 & 1.12 & 3.03 & 0.11 \\
\hline Tanana, AK (307) & 20 & 0.67 & 0.46 & 0.78 & 0.02 & 20 & 2.19 & 0.77 & 3.14 & 0.16 \\
\hline Galena, AK (308) & 20 & 0.62 & 0.51 & 0.68 & 0.01 & 20 & 1.80 & 1.16 & 2.52 & 0.08 \\
\hline Innoko, AK (309) & 20 & 0.55 & 0.46 & 0.74 & 0.02 & 21 & 1.14 & 0.63 & 2.93 & 0.12 \\
\hline Kotlik, AK (310) & 17 & 0.63 & 0.57 & 0.71 & 0.01 & 17 & 3.33 & 2.42 & 4.76 & 0.13 \\
\hline \multicolumn{11}{|l|}{ Longnose sucker } \\
\hline Basin Total & 46 & 0.81 & 0.63 & 1.10 & 0.01 & -- & -- & -- & -- & -- \\
\hline Charley-Kandik, AK (301) & 12 & 0.76 & 0.66 & 0.89 & 0.02 & -- & -- & -- & -- & -- \\
\hline The Bridge, AK (304) & 2 & 0.86 & 0.85 & 0.88 & 0.01 & -- & -- & -- & -- & -- \\
\hline Fairbanks, AK (305) & 21 & 0.80 & 0.65 & 0.91 & 0.02 & -- & -- & -- & -- & -- \\
\hline Tolovana, AK (306) & 3 & 0.76 & 0.63 & 0.83 & 0.07 & -- & -- & -- & -- & -- \\
\hline Galena, AK (308) & 8 & 0.94 & 0.86 & 1.10 & 0.03 & -- & -- & -- & -- & -- \\
\hline \multicolumn{11}{|l|}{ Burbot } \\
\hline Basin Total & 13 & 0.56 & 0.43 & 0.75 & 0.02 & 13 & 5.78 & 2.90 & 9.77 & 0.59 \\
\hline Fairbanks, AK (305) & 12 & 0.56 & 0.43 & 0.75 & 0.02 & 12 & 5.70 & 2.90 & 9.77 & 0.64 \\
\hline Kotlik, AK (310) & 1 & 0.60 & -- & -- & -- & 1 & 6.77 & -- & -- & -- \\
\hline
\end{tabular}

(80\%) of longnose sucker had SSI between 0.15 and $0.40 \%$, and all SSI $>0.33 \%$ were calculated for fish from Station 305 (Fig. 14). The BEST LRMN collected longnose and largescale sucker in the CRB in 1997 (Hinck and others, 2004). The basinwide SSI mean for CRB largescale sucker was $0.25 \%$ with station means ranging from 0.17 to $0.37 \%$, and individual SSI values for longnose sucker were $0.02-0.39 \%$ (Hinck and others, 2004). SSI values from the YRB were similar to those calculated in the CRB.

\section{Cellular and Histopathological Indicators}

Splenic macrophage aggregates were quantified and measured and are described in the following paragraphs. Gonadal tissue was examined microscopically and is described in a later section devoted to reproductive biomarkers.

\section{Macrophage Aggregates}

Macrophage aggregates are believed to house endogenous and exogenous waste products and are active in the immune responses to these materials (Schmitt and Dethloff, 2000). Three macrophage aggregate parameters, density or number of aggregates per $\mathrm{mm}^{2}$ (MA-\#), mean size of aggregates in $\mu \mathrm{m}^{2}$ (MA-size), and percent of tissue occupied by macrophage aggregates (MA-\%) were analyzed for northern pike, longnose sucker, and burbot from the YRB. Gender and age have been reported to influence macrophage aggregate parameters in various species (Blazer and others, 2002; Hinck and others, 2004; Schmitt and others, 2004); therefore, ANOVAs using these factors for each species were examined to determine if these factors affected MA data in northern pike and longnose sucker in the YRB.

MA-\#

Neither gender nor age influenced MA-\# in northern pike and longnose sucker (Table 13); therefore, genders were combined for data analysis. The basinwide mean MA-\# for northern pike was 3.7 MA/mm², and station means for northern pike ranged from $2.7 \mathrm{MA} / \mathrm{mm}^{2}$ at Station 308 to $5.2 \mathrm{MA} / \mathrm{mm}^{2}$ at Station 306 (Table 19). Individual MA-\# in northern pike ranged from 0.0 to $12.9 \mathrm{MA} / \mathrm{mm}^{2}$ (Fig. 15). MA-\# were $>10$ $\mathrm{MA} / \mathrm{mm}^{2}$ in northern pike from Stations 302, 303, and 306. Most northern pike (94\%) had MA-\# $<8.0 \mathrm{MA} / \mathrm{mm}^{2}$, and MA\# did not differ significantly among stations (Table 13). Other studies reporting MA-\# data for northern pike were not found.

MA-\# in longnose sucker were greater than in northern 


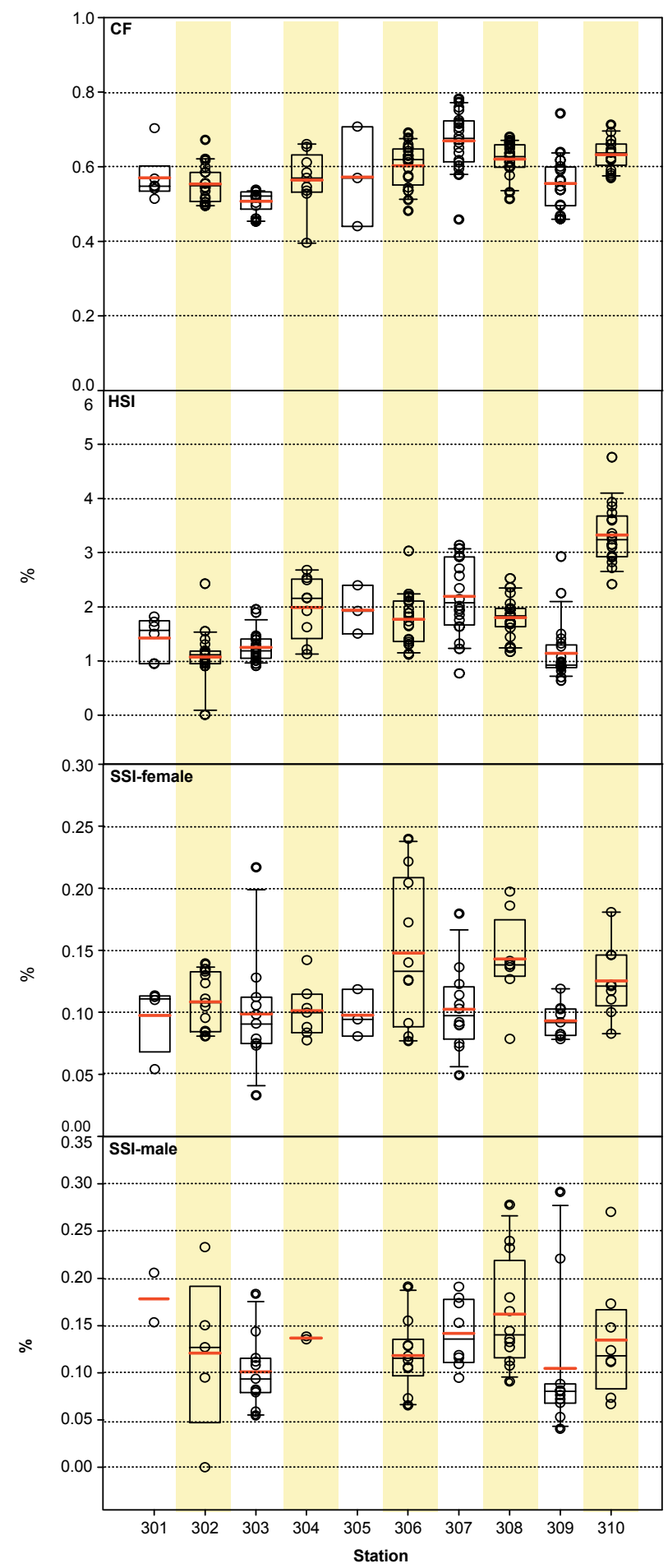

Figure 13. Fish health indicators by station in female and male northern pike collected in the Yukon River Basin in 2002. Indicators include condition factor (CF), hepatosomatic index (HSI), and splenosomatic index (SSI). Females and males were plotted separately when analysis of variance modeling determined gender was a significant factor. Shown for each group are points representing individual fish and the mean (red horizontal line), median (black horizontal line), interquartile range (box), and the 10th and 90th percentiles (whiskers). Stations are ordered upstream to downstream. See Table 1 for station descriptions. pike in the YRB. The basinwide mean MA-\# for longnose sucker was $5.5 \mathrm{MA} / \mathrm{mm}^{2}$, and station means ranged from 2.4 $\mathrm{MA} / \mathrm{mm}^{2}$ at Station 308 to $11.5 \mathrm{MA} / \mathrm{mm}^{2}$ at Station 304 (Table 19). Individual MA-\# for longnose sucker ranged from 0.0 to $21.2 \mathrm{MA} / \mathrm{mm}^{2}$ with the majority $(70 \%)$ having MA-\# of 1.0-10.0 MA $/ \mathrm{mm}^{2}$ (Fig. 16). Five fish from Stations 301, 304, and 305 had MA-\# values $>12.0 \mathrm{MA} / \mathrm{mm}^{2}$. MA-\# differed significantly among stations for longnose sucker (Table 13). Previous studies on MA-\# in longnose sucker have not been documented. Hinck and others (2004) reported mean station MA-\# to range from 4.9 to $8.7 \mathrm{MA} / \mathrm{mm}^{2}$ and a basinwide mean of $6.8 \mathrm{MA} / \mathrm{mm}^{2}$ in largescale sucker in the CRB.

MA-\# data for burbot were only available for Station 305 (Table 19). The station mean was 3.9 with a range of 0.6-8.8 MA $/ \mathrm{mm}^{2}$. These data were similar to MA-\# values for northern pike and longnose sucker, although other studies documenting MA-\# in burbot were not located.

\section{MA-Size}

Gender and age did not influence MA-size in northern pike or longnose sucker (Table 13); therefore, genders were combined for data analysis. The basinwide mean MA-size for northern pike was $1,134 \mu \mathrm{m}^{2}$ with station means ranging from $849 \mu^{2}$ at Station 304 to $1,333 \mu \mathrm{m}^{2}$ at Station 307 (Table 19). Most northern pike (92\%) had MA-size ranging from 200 to $2,000 \mu \mathrm{m}^{2}$ (Fig. 15). These data did not support that MA-size varied significantly among stations for northern pike (Table 13). MA data in northern pike from other studies were not found.

In general, MA-size was greater in longnose sucker than in northern pike, with longnose sucker having a basinwide mean of 2,095 $\mu^{2}$ (Table 19). MA-size station means for longnose sucker ranged from 1,486 $\mu \mathrm{m}^{2}$ at Station 308 to 2,672 $\mu \mathrm{m}^{2}$ at Station 301, and individual MA-size in longnose sucker ranged from 0 to $8,201 \mu \mathrm{m}^{2}$ (Table 19; Fig. 16). Stations 301, 305 , and 308 had MA-size in longnose sucker $>4,000 \mu \mathrm{m}^{2}$, but most longnose sucker (71\%) had MA-size of 500-3,000 $\mu \mathrm{m}^{2}$ (Fig. 16). As in northern pike, MA-size did not vary significantly among stations for longnose sucker (Table 13). MA-size data for longnose sucker from other studies were not found. However, largescale sucker from the CRB had a basinwide mean MA-size of 3,580 $\mathrm{m}^{2}$ with the station means ranging from 2,821 to $4,941 \mu^{2}$ (Hinck and others, 2004). The CRB data for largescale sucker is slightly greater than MA-size data for longnose sucker in the YRB.

MA-size data for burbot were only available for Station 305. The station mean for MA-size in burbot was 62,860 $\mu \mathrm{m}^{2}$ with individual values ranging from 368 to $250,000 \mu \mathrm{m}^{2}$ (Table 19). The MA-size data in burbot were greater than any data measured by the BEST Program, although MA parameters can vary by species (Schmitt and Dethloff, 2000). No other studies examining MA-size in burbot were available for comparison to YRB data. 
Table 18. Arithmetic mean of splenosomatic index (SSI; \%) by species, gender, and station in northern pike, longnose sucker, and burbot collected in the Yukon River Basin in 2002. Number of samples $(n)$, minimum (min.), maximum (max.), and standard error (SE) are also given. Stations are ordered upstream to downstream. The maximum station mean for each taxon is shown in bold.

\begin{tabular}{|c|c|c|c|c|c|}
\hline Species, Gender, and Station & $n$ & Mean & Min. & Max. & SE \\
\hline \multicolumn{6}{|l|}{ Northern pike } \\
\hline \multicolumn{6}{|l|}{ Female } \\
\hline Basin Total & 88 & 0.113 & 0.033 & 0.240 & 0.004 \\
\hline Charley-Kandik, AK (301) & 4 & 0.098 & 0.054 & 0.114 & 0.015 \\
\hline Fish Hook Bend, AK (302) & 15 & 0.108 & 0.080 & 0.139 & 0.006 \\
\hline Fort Yukon, AK (303) & 11 & 0.099 & 0.033 & 0.217 & 0.014 \\
\hline The Bridge, AK (304) & 7 & 0.101 & 0.077 & 0.142 & 0.008 \\
\hline Fairbanks, AK (305) & 3 & 0.098 & 0.081 & 0.118 & 0.011 \\
\hline Tolovana, AK (306) & 10 & 0.148 & 0.077 & 0.240 & 0.019 \\
\hline Tanana, AK (307) & 12 & 0.102 & 0.049 & 0.179 & 0.010 \\
\hline Galena, AK (308) & 8 & 0.143 & 0.079 & 0.197 & 0.013 \\
\hline Innoko, AK (309) & 9 & 0.093 & 0.078 & 0.119 & 0.005 \\
\hline Kotlik, AK (310) & 9 & 0.125 & 0.083 & 0.181 & 0.010 \\
\hline \multicolumn{6}{|l|}{ Male } \\
\hline Basin Total & 68 & 0.130 & 0.041 & 0.291 & 0.007 \\
\hline Charley-Kandik, AK (301) & 2 & 0.180 & 0.153 & 0.206 & 0.027 \\
\hline Fish Hook Bend, AK (302) & 4 & 0.151 & 0.095 & 0.233 & 0.029 \\
\hline Fort Yukon, AK (303) & 11 & 0.101 & 0.055 & 0.183 & 0.011 \\
\hline The Bridge, AK (304) & 2 & 0.137 & 0.135 & 0.139 & 0.002 \\
\hline Tolovana, AK (306) & 10 & 0.118 & 0.066 & 0.191 & 0.012 \\
\hline Tanana, AK (307) & 8 & 0.142 & 0.094 & 0.191 & 0.013 \\
\hline Galena, AK (308) & 12 & 0.162 & 0.091 & 0.278 & 0.017 \\
\hline Innoko, AK (309) & 11 & 0.105 & 0.041 & 0.291 & 0.023 \\
\hline Kotlik, AK (310) & 8 & 0.135 & 0.067 & 0.270 & 0.023 \\
\hline \multicolumn{6}{|l|}{ Longnose sucker } \\
\hline Basin Total & 46 & 0.237 & 0.017 & 0.448 & 0.014 \\
\hline Charley-Kandik, AK (301) & 12 & 0.240 & 0.151 & 0.326 & 0.017 \\
\hline The Bridge, AK (304) & 2 & 0.176 & 0.082 & 0.269 & 0.094 \\
\hline Fairbanks, AK (305) & 21 & 0.274 & 0.017 & 0.448 & 0.023 \\
\hline Tolovana, AK (306) & 3 & 0.123 & 0.103 & 0.151 & 0.014 \\
\hline Galena, AK (308) & 8 & 0.194 & 0.126 & 0.250 & 0.012 \\
\hline \multicolumn{6}{|l|}{ Burbot } \\
\hline Basin Total & 13 & 0.067 & 0.046 & 0.098 & 0.005 \\
\hline Fairbanks, AK (305) & 12 & 0.069 & 0.049 & 0.098 & 0.005 \\
\hline Kotlik, AK (310) & 1 & 0.046 & -- & -- & -- \\
\hline
\end{tabular}

$\mathrm{MA}-\%$

Gender and age did not influence MA-\% in northern pike and longnose sucker (Table 13); therefore, genders were combined for data analysis. The basinwide mean MA- $\%$ in northern pike was $0.43 \%$ with station means ranging from $0.31 \%$ at Station 310 to $0.59 \%$ at Station 305 (Table 19). Station 305 also had the greatest MA-\# for northern pike. Individual MA-\% in northern pike ranged from 0 to $1.78 \%$ in the YRB (Fig. 15), and MA-\% did not vary significantly among stations (Table 13). MA-\% data in northern pike from other studies were not found.

The percent tissue occupied by MA was greater in longnose sucker compared to northern pike in the YRB with a basinwide mean of $1.26 \%$ (Table 19). Station means ranged from $1.04 \%$ at Station 304 to $1.78 \%$ at Station 301 in longnose sucker (Table 19; Fig. 16), but station means were not significantly different (Table 13). Four female longnose sucker from Stations 305 and 308 had MA-\% $>3.0 \%$, whereas most longnose sucker (89\%) had MA-\% between 0.1 and $2.0 \%$ (Fig. 16). Additional studies reporting MA- $\%$ in longnose sucker were not found. Largescale sucker from the CRB had a basinwide mean MA- $\%$ of $2.4 \%$ with station means ranging from 1.8 to $3.8 \%$ (Hinck and others, 2004), which is greater than longnose sucker data from the YRB.

MA-\% data for burbot were only available for Station 305 (Table 19). The station mean was $4.7 \%$ with a range of $0.02-15.13 \%$, which is greater than the MA-\% for northern pike and longnose sucker. Other studies documenting MA-\# in burbot were not available. 


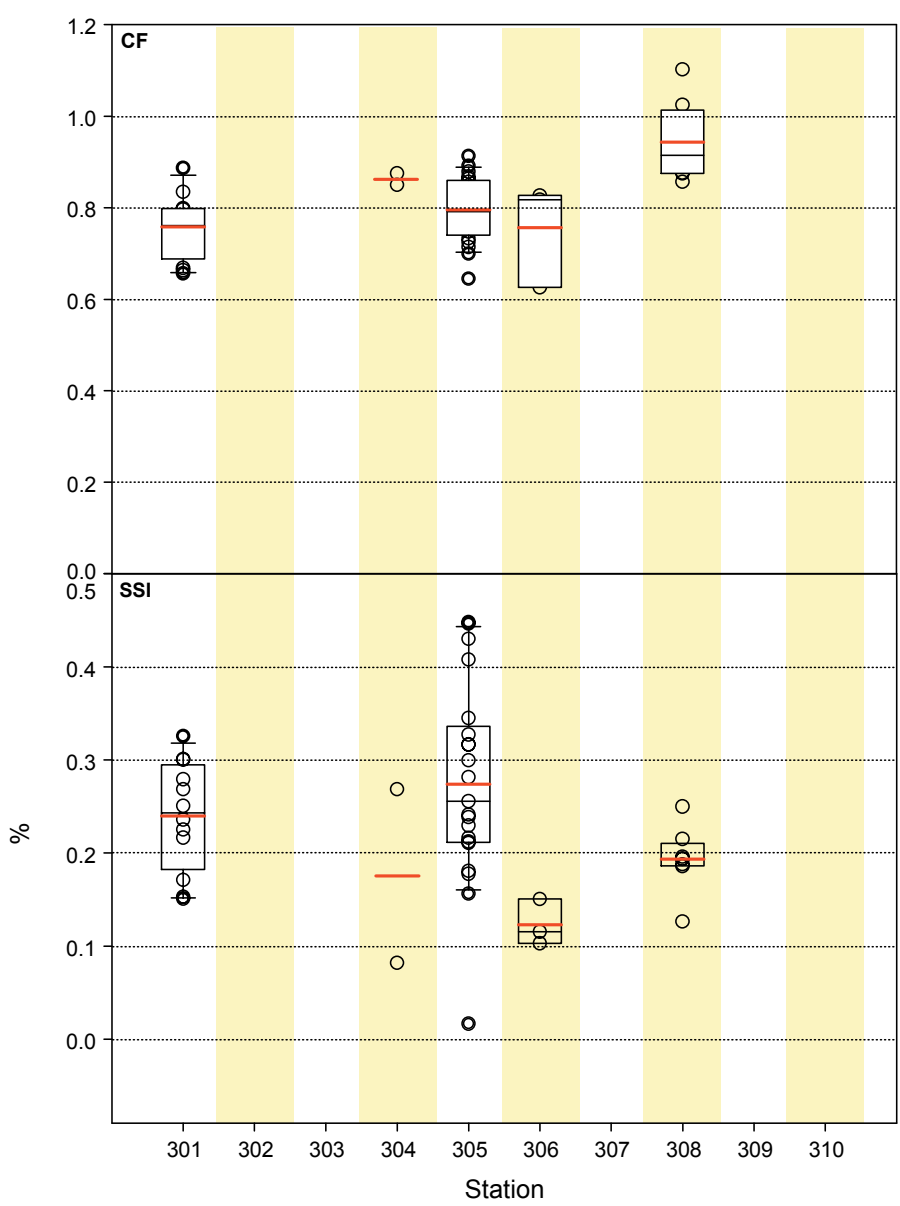

Figure 14. Fish health indicators by station in female and male longnose sucker collected in the Yukon River Basin in 2002. Indicators include condition factor (CF) and splenosomatic index (SSI). Shown for each group are points representing individual fish and the mean (red horizontal line), median (black horizontal line), interquartile range (box), and the 10th and 90th percentiles (whiskers). Stations are ordered upstream to downstream. See Table 1 for station descriptions.

\section{Fish Health Indicators: Summary}

Fish health indicators for this project and previous BEST projects were selected to evaluate major organ systems and their functions (Hinck and others, 2004; Schmitt, 2002a; Schmitt and others, 2004). The BEST LRMN continued to accumulate information on the target species for comparison with various large river basins and regions throughout the U.S. and for the determination of "normal" ranges for many of these indicators. Various factors including age, gender, reproductive status, and geographic location as well as contaminants can affect these fish health indicators that were selected to reflect overall organismal health of the fish and their populations.

Fish were collected in the summer and fall of 2002, sexed and aged, and analyzed by species in an attempt to eliminate as many confounding factors as possible. Potential effects of gender and age on comparisons among stations were evaluated statistically. Age, known to significantly influence MA-\# in some fishes, was considered in the statistical model for station comparisons of these parameters (Brown and George, 1985). Analysis of the data indicated no effect of gender or age (for the MA parameters) on external lesions, CF, HAI, MA-\#, MA-size, or MA-\% in northern pike or longnose sucker, SSI in longnose sucker, and HSI in northern pike. SSI in northern pike differed significantly between genders; therefore, males and females were evaluated separately. HSI in northern pike was analyzed by gender due to the role of the liver in vitellogenesis and the associated physiological changes in the liver throughout the female reproductive cycle.

Forty-seven percent of the fish collected from the YRB were identified as having external lesions. External lesions were identified on $51 \%$ of northern pike, $41 \%$ of longnose sucker, and $8 \%$ of burbot. Fish from several stations had high proportions $(>60 \%)$ of external lesions. However, most of the lesions were attributed to old scars or marks on the body surface. No fish were identified as having active fin erosion, skeletal or fin deformities, body surface tumors, or eye lesions that have been previously associated with exposure to anthropogenic stressors or degraded environments (Fournie and others, 1996; McCain and others, 1992; Sindermann, 1979).

Caution must be exercised when comparing external lesions of YRB fish with those of other studies and even in comparing stations in our study. Errors in proportions of anomalous fish can result from biased or differential examination of fish, species composition, habitat, and other factors unrelated to environmental degradation (Leonard and Orth, 1986). This error in our study could be compounded because many different individuals were involved in assessing external lesions. A second confounding factor in comparing the results of various studies is the consideration of different anomalies. This study evaluated abnormalities of the body surface, eyes, opercles, and fins, including deformities and parasites.

The HAI, which is also an assessment of grossly visible lesions, is more comprehensive than the incidence of external lesions because it accounts for both external and internal abnormalities. To our knowledge, this methodology has had limited use with northern pike and longnose sucker. Station means of HAI in the YRB ranged from 10 to 92 for northern pike and 29 to 70 for longnose sucker. Northern pike from the MRB (Schmitt and others, 2002a) and RGB (Schmitt and others, 2004) had similar HAI scores. No other studies were found that evaluated HAI in northern pike. Studies examining HAI in longnose sucker were limited but HAI in YRB fish were generally less than sucker (Catostomus spp.) from the CRB (Hinck and others, 2004).

CF may indicate changes at the organism level and is directly affected by nutrition (Tyler and Dunn, 1976), as well as by season, sexual maturation, and disease (Adams and others, 1982; Denton and Yousef, 1976; Möller, 1985). Elevated CF has been linked to exposure to contaminants such as pulp mill effluent (Adams and others, 1992; McMaster and others, 1991; Oakes and others, 2004) and municipal sewage effluents 


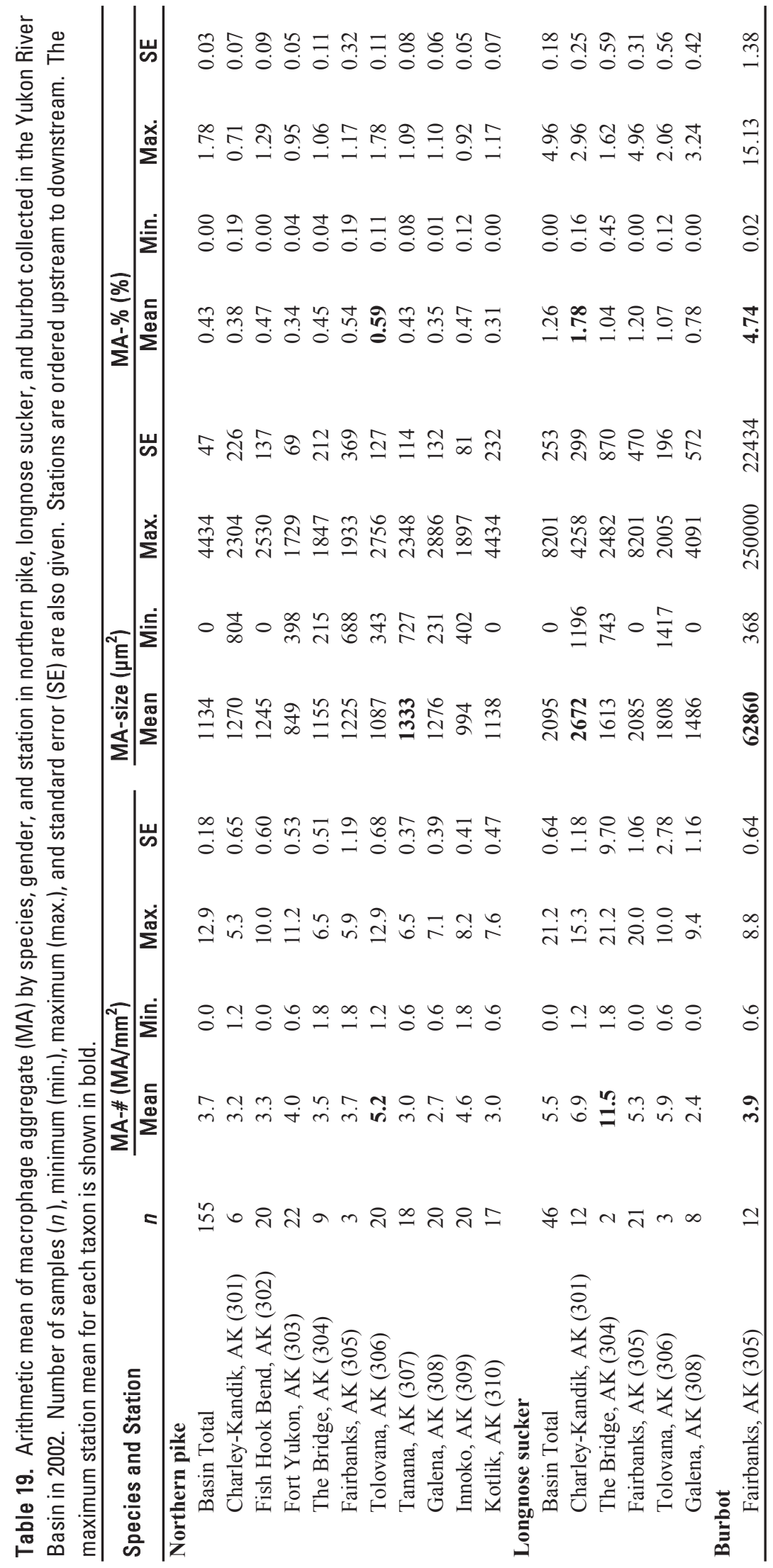




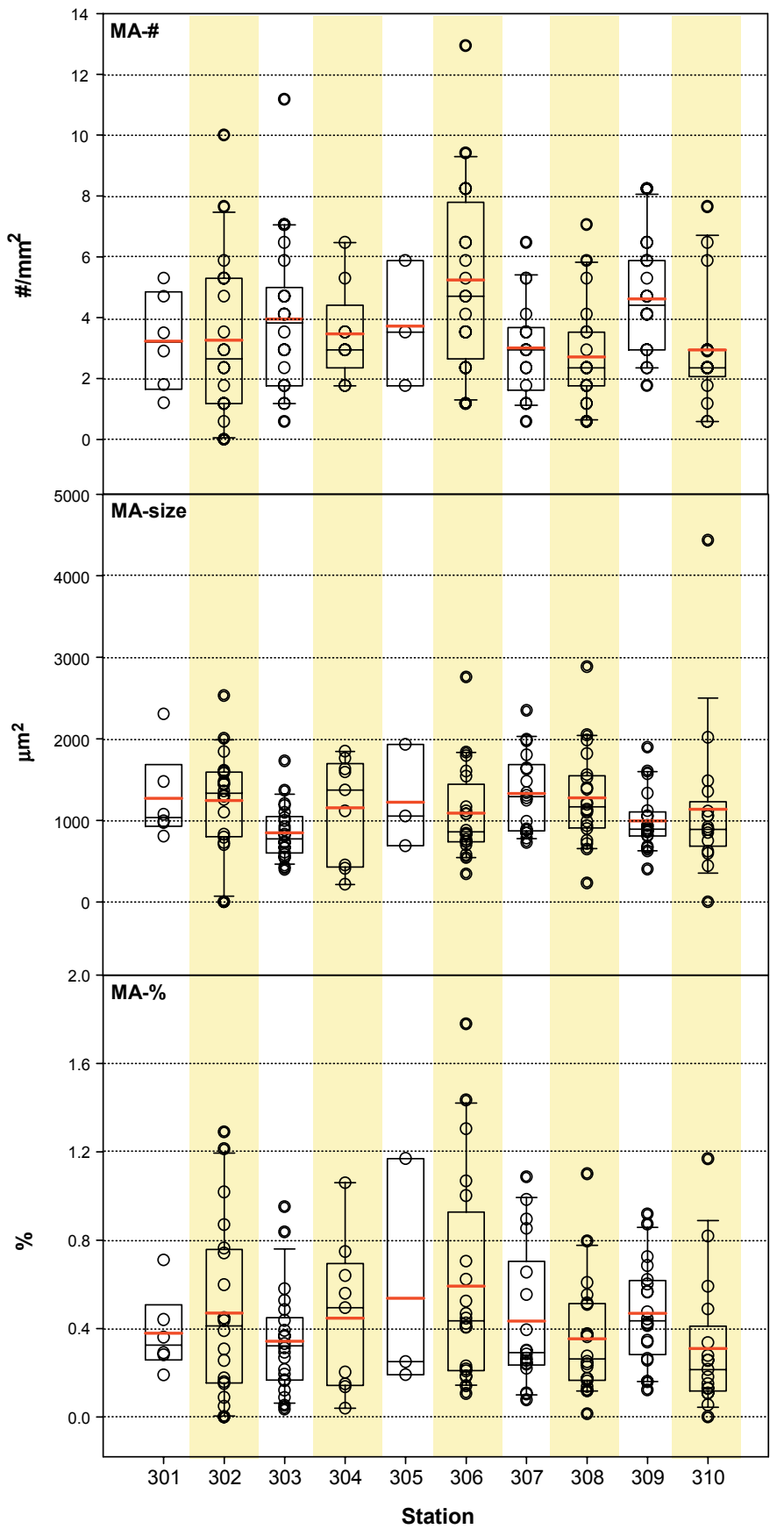

Figure 15. Splenic macrophage aggregate parameters by station in northern pike collected in the Yukon River Basin in 2002. Parameters include macrophage aggregate density (MA-\#), macrophage aggregate area (MA-size), and percent of splenic tissue occupied by macrophage aggregates (MA-\%). Shown for each group are points representing individual fish and the mean (red horizontal line), median (black horizontal line), interquartile range (box), and the 10th and 90th percentiles (whiskers). Stations are ordered upstream to downstream. See Table 1 for station descriptions.

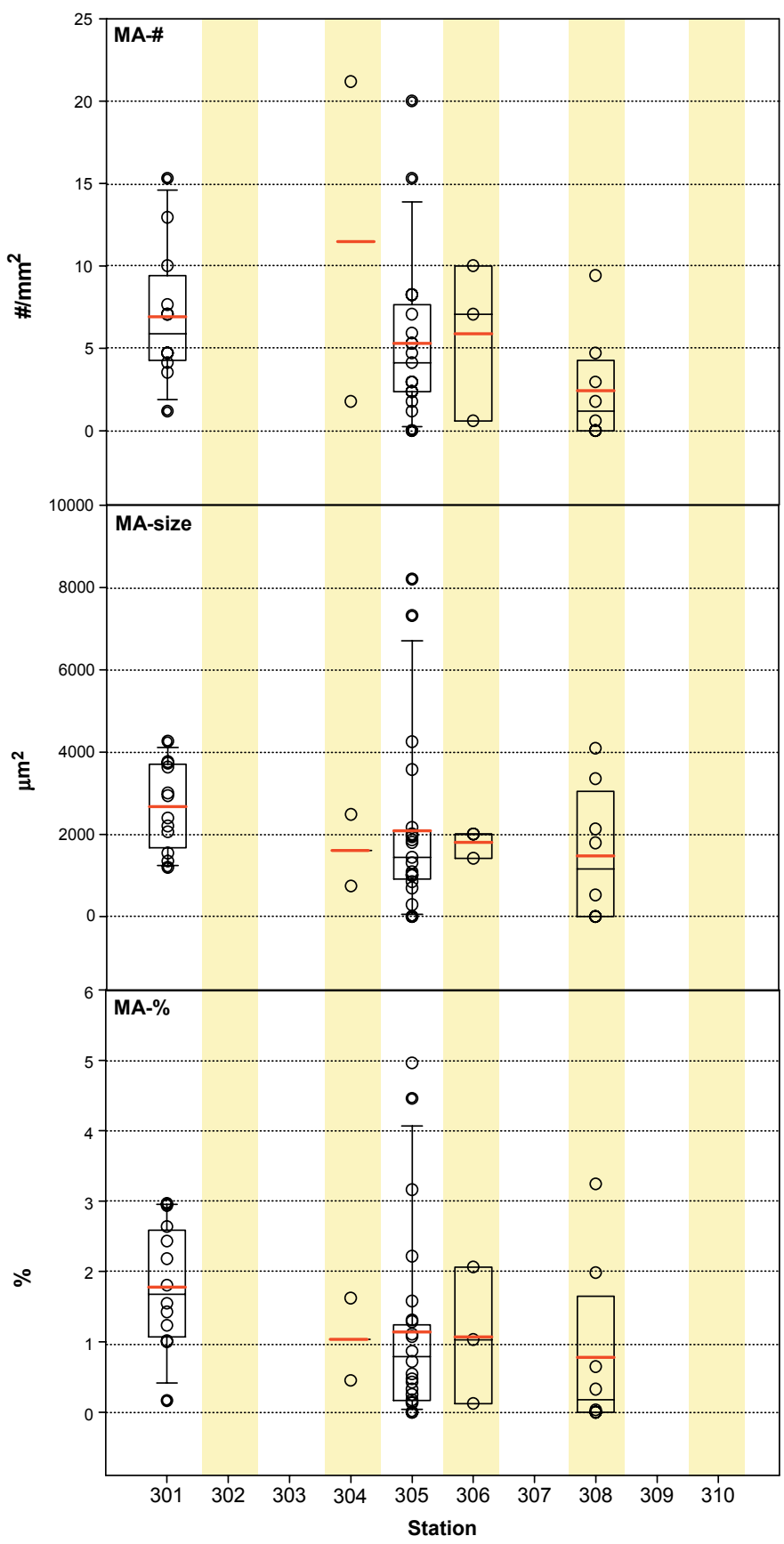

Figure 16. Splenic macrophage aggregate parameters by station in longnose sucker collected in the Yukon River Basin in 2002.

Parameters include macrophage aggregate density (MA-\#), macrophage aggregate area (MA-size), and percent of splenic tissue occupied by macrophage aggregates (MA-\%). Shown for each group are points representing individual fish and the mean (red horizontal line), median (black horizontal line), interquartile range (box), and the 10th and 90th percentiles (whiskers). Stations are ordered upstream to downstream. See Table 1 for station descriptions. 
(Oakes and others, 2004), whereas diminished CF has been observed after exposure to contaminants such as metals and petroleum (Kiceniuk and Khan, 1987; Miller and others, 1992; Munkittrick and Dixon, 1988). Condition factor can also vary among locations within a species (Doyon and others, 1988; Fisher and others, 1996). The range of CF station means for northern pike in the YRB was 0.51-0.67 with no station being notable for low CF. Longnose sucker had greater CF than northern pike with station means ranging from 0.76 to 0.94 with no significant differences among stations.

The HSI may vary with season (Beamish and others, 1996; Delahunty and de Vlaming, 1980), temperature (Fine and others, 1996), and nutrition (Daniels and Robinson, 1986; Foster and others, 1993) as well as with gender and changes in gonadal status (Fabacher and Baumann, 1985; Förlin and Haux, 1990; Grady and others, 1992). It is also the organosomatic index for which changes are most often associated with contaminant exposure (Adams and McLean, 1985). Increased HSI has been reported with exposure of wild fish to organic contaminants, most often PAHs and PCBs, whereas laboratory exposures of fish to metals, crude oil, certain pesticides, and bleached kraft mill effluent have resulted in HSI decreases (Schmitt and Dethloff, 2000). A comparative range for normal liver weight in fish is $1-3 \%$ of body weight, with relative weights $>2 \%$ being uncommon (Gingerich, 1982). HSI were not calculated for longnose sucker due to the diffuse nature of their livers. Only northern pike from Station 310 had HSI $>3 \%$. However, these fish were collected in early May, resulting in elevated, but not significantly greater, HSI compared to the other YRB stations where northern pike were collected after spawning had occurred.

The SSI is measured to determine changes in the relative size of the spleen, a primary hematopoietic organ in fish. The SSI can differ among species, genders, and locations and can change over age, size, gonadal development, and season (Krykhtin, 1976; Ruklov, 1979; White and Fletcher, 1985). Studies have also documented changes in relative spleen size with exposure to chemical contaminants. Fish exposed to organic contaminants alone or in combination with metals have had decreased SSI, but increased SSI has rarely been documented with contaminant exposure (Schmitt and Dethloff, 2000). An increase in SSI is considered indicative of disease or immune problems (Goede and Barton, 1990). Capture and holding stress have been reported to alter SSI and HSI in field studies (Schmitt and Dethloff, 2000). Stations in the YRB are described as having high or low SSI relative to other stations because "normal" ranges are not available for northern pike and longnose sucker. Station means for SSI ranged from 0.09 to $0.15 \%$ in female northern pike and 0.10 to $0.18 \%$ in male northern pike. Stations 306, 308, and 310 had the greatest station means $(>0.12 \%)$ for female northern pike with SSI values in individual fish exceeding $0.15 \%$. SSI in longnose sucker was greater than in northern pike. Longnose sucker from Stations 301 and 305 had greater mean SSI although other stations had limited sample sizes.
Macrophage aggregate parameters were also evaluated in the YRB. Station means for MA-\# were 2.7-5.2 MA/mm² in northern pike and 2.4-11.5 MA/mm $\mathrm{mm}^{2}$ in longnose sucker. Fournie and others (2001) suggested than splenic MA densities of $>40 \mathrm{MA} / \mathrm{mm}^{2}$ in at least one fish from a site were correlated with hypoxic stress or high levels of sediment contamination for a variety of estuarine fishes and irrespective of age. There is insufficient data to know if this is a reasonable reference number for freshwater fishes or how MA may be correlated with body burdens of various contaminants. However, none of the fish collected from the YRB exceeded $40 \mathrm{MA} / \mathrm{mm}^{2}$.

Increases in MA parameters in fish collected from specific contaminated sites relative to reference groups or sites have been found in both laboratory and field studies (Blazer and others, 1994; 1997; Wolke, 1992). Programs such as the USEPA Environmental Monitoring and Assessment Program (EMAP) Estuaries program (Fournie and others, 2001; Summers and others, 1993) and NOAA's Status and Trends programs (Chang and others, 1998) have also used MA parameters as bioindicators. Macrophage aggregates have been identified in various tissues including spleen, liver, and kidney although most studies using splenic MAs have been performed in marine or estuarine environments. Most studies have only evaluated MA density, and even for this parameter, no regional baseline information exists to establish a "normal" value for any species. To our knowledge, there have not been any studies evaluating MAs and potential effects of contaminant exposure in northern pike or longnose sucker. Numerous studies have reported various factors including size, nutritional status (Agius, 1979; 1980; Agius and Roberts, 1981; Wolke and others, 1985), age (Blazer and others, 1987; Brown and George, 1985; Couillard and Hodson, 1996), and exposure time (many as reported in Schmitt and Dethloff, 2000) can affect macrophage aggregates in different species.

Histological evaluation of various tissues suggested the majority of lesions observed were parasite related (Appendix 2). Five percent of the northern pike at Station 309 (Innoko NWR Field Station) had altered foci in the liver, and $33 \%$ of longnose sucker at Station 306 (Tolovana) had bile duct proliferation (Appendix 2). Both of these lesions have been associated with exposure to contaminants in other fish species (Bunton and others, 1987; Myers and others, 1994; Stehr and others, 2003; Teh and Hinton, 1993).

\section{Reproductive Biomarkers}

\section{Gonadal Histopatholgy, Vitellogenin, and Steroid Hormones}

Gonadal histopathology and GSI are reproductive indicators that provide structural information about gonadal health and maturational stage (Schmitt and Dethloff, 2000). Vitel- 
logenin provides information on stage of maturation and the estrogenicity of various compounds (Schmitt and Dethloff, 2000). Steroid hormones including estradiol (E2), 11-ketotestosterone (KT), and estradiol/11-ketotestosterone ratio (E/KT) are used to monitor subtle physiological changes that could lead to long-term population level effects (Schmitt and Dethloff, 2000). Evaluation of all of these reproductive biomarkers may be confounded by factors including season, age, gender, and chemical contaminants that have been reported to affect these reproductive biomarkers (Schmitt and Dethloff, 2000). Reproductive biomarkers were evaluated relative to the stage of gonad development of fish in the YRB (see Figs. 2 and 3). The gender and gonadal stage of northern pike and longnose sucker did not influence GSI, vtg, or atresia, but steroid hormones were influenced by stage or gender in some models (Table 13). The data for male and female northern pike and longnose sucker were examined separately based on a review of the literature and previous BEST LRMN projects. Steroid hormone data for Station 307 was limited to a single male northern pike.

\section{Female Northern Pike}

Examining the stage of gonad development is critical for the interpretation of reproductive biomarkers. Female northern pike were in stages 1-5 with the majority identified as stage $2(33 \%)$ and stage $5(32 \%)$ (Fig. 17). Other stages presented were stage $1(20 \%)$, stage $3(1 \%)$, and stage $4(14 \%)$. Stage-1 females were collected from Stations 303, 304, 305, 306, 307, and 309; stage-2 females were identified at Stations 302, 303, 304, 305, 306, 308, and 309. A single stage-3 female northern pike was collected at Station 303. Female northern pike from Station 310 were all stage 4, and other stations having stage-4 females included Stations 305, 306, and 307. Stations 301, 303, 304, 306, 307, and 308 had stage-5 female northern pike.

The basinwide mean GSI was $2.0 \%$ in female northern pike in the YRB (Table 20). The GSI was greatest (11.9\%) in females from Station 310, with individual fish having GSI ranging from 5.7 to $16.5 \%$. Other station means were $<2.8 \%$ for female northern pike (Table 20; Fig. 18). However, fish from Station 310 were collected earlier (in early May) than other stations. All female pike from Station 310 were stage 4 (late development of oocytes with large follicles). In fact, all female northern pike with GSI $>2 \%$ were stage 4 . All other female northern pike had GSI ranging between 1 and 2\% (Fig. 18). However, GSI in female northern pike did not vary significantly among YRB stations, and stage was not a significant factor in the model (Table 13). Few studies were located that described GSI in female northern pike. GSI ranged from 0.05 to $2.6 \%$ in female northern pike collected in September from the Missouri River near Garrison Dam, North Dakota; gonadal stage of northern pike was not determined in this study (McDonald and others, 2002). Schmitt and others (2004) reported GSI in male northern pike collected in September-
October to range from 0.5 to $4.9 \%$ near Alomosa, Colorado in the RGB, although no stage data were available for these fish.

Female and male northern pike were examined separately for vtg even though gender was not found to influence vtg concentrations (Table 13). This lack of gender difference in concentrations of vtg may be a result of small sample size and narrow range of concentrations or both. The basinwide mean for vtg in female northern pike was $0.77 \mathrm{mg} / \mathrm{mL}$, and the station means ranged from $0.09 \mathrm{mg} / \mathrm{mL}$ at Station 308 to 5.32 $\mathrm{mg} / \mathrm{mL}$ at Station 305 (Table 20). However, vtg data from Station 305 was limited to one stage-4 female northern pike collected in October whereas most other northern pike were collected during the summer (June-July). This indicated that gonadal stage and, to some extent, collection date influenced concentrations of vtg. Stage-4 female northern pike from Stations 301 and 310 also had greater vtg concentrations than other YRB stations. Most female northern pike (67\%) had concentrations of vtg between 0.1 and $1.3 \mathrm{mg} / \mathrm{mL}$ (Fig. 18). Other studies reporting concentrations of vtg in female northern pike were not found.

Mean percent atresia in northern pike was similar among YRB stations. Basinwide mean percent atresia was $1.1 \%$, and station means ranged from $0.0 \%$ at Station 310 to $2.9 \%$ at Station 304 (Table 20). Percent atresia was $<8 \%$ for all northern pike except in four females from Stations 302 and 304 (Fig. 18). YRB station means did not significantly differ for percent atresia in female northern pike (Table 13). Atresia data is limited for northern pike. June (1970) concluded that high incidence of atresia $(>10 \%)$ in northern pike ovaries from Missouri River impoundments was associated with fluctuations in water temperature or level. In addition, follicular atresia was found to be more common in northern pike than others species including burbot in a Missouri River reservoir (June, 1977).

Female and male northern pike were examined separately for steroid hormones because gender influenced concentrations of KT (Table 13). The basinwide mean of E2 in female northern pike was $1,111 \mathrm{pg} / \mathrm{mL}$, and station means ranged from $393 \mathrm{pg} / \mathrm{mL}$ at Station 309 to $1,565 \mathrm{pg} / \mathrm{mL}$ at Station 302 (Table 21). Gonadal stage and collection date did not appear to influence concentrations of E2 in female northern pike, and station means did not differ significantly in regards to E2 (Table 13). Concentrations of E2 were $>2,000 \mathrm{pg} / \mathrm{mL}$ in female northern pike from Stations 302 and 308 (Fig. 18). Most female northern pike (78\%) had concentrations of E2 between 290 and 2,000 pg/mL (Fig. 18).

Concentrations of KT were less than E2 in female northern pike. The basinwide mean of KT in female northern pike was $494 \mathrm{pg} / \mathrm{mL}$ (Table 21). Station means for KT in female northern pike varied significantly and ranged from $162 \mathrm{pg} / \mathrm{mL}$ at Station 305 to $708 \mathrm{pg} / \mathrm{mL}$ at Station 304 (Fig. 18; Table 13). Female northern pike from Stations 303, 304, 306, 308, and 309 had concentrations of $\mathrm{KT}>1,000 \mathrm{pg} / \mathrm{mL}$. Mean station $\mathrm{E} / \mathrm{KT}$ ratios ranged from 1.63 at Station 309 to 6.83 at Station 302 in female northern pike (Table 21; Fig. 18). Female northern pike (26\%) from all stations except Stations 301, 305, and 307 , had E/KT ratios <1.0; gondal stage of these fish varied 


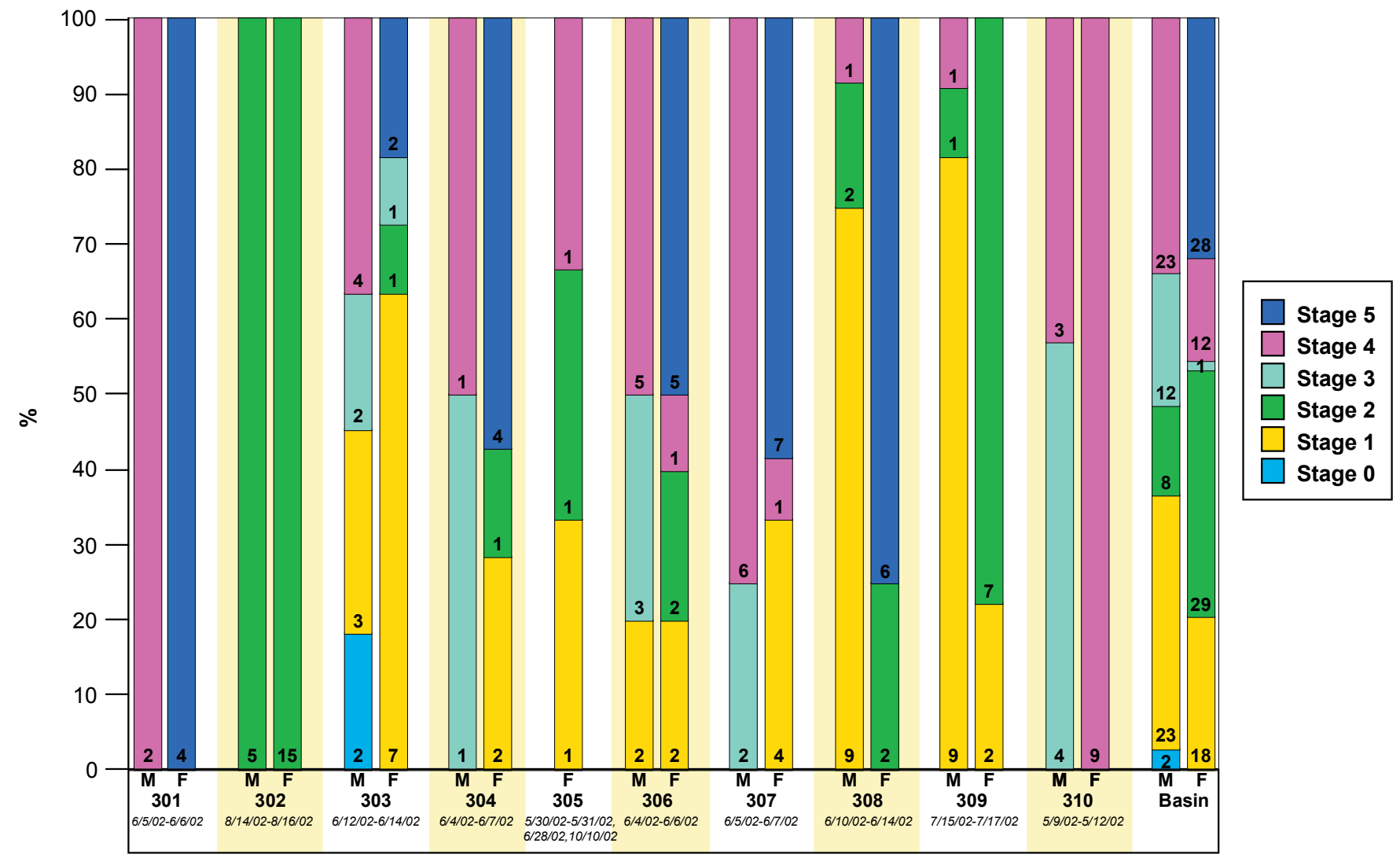

Figure 17. Gonadal stage of female and male northern pike collected in the Yukon River Basin in 2002. Shown are the percentages ( $y$-axis) and sample sizes (within the bars) of fish in each stage. The collection dates for each station are also shown. Stations are ordered upstream to downstream. See Table 1 for station descriptions.

(Fig. 18). Other studies reporting concentrations of steroid hormones in female northern pike were not found.

\section{Male Northern Pike}

Stage of gonad development and gender were examined in order to interpret reproductive biomarkers in male northern pike. Stage of male northern pike was not related to capture date. Male northern pike were in stages $0-4$, with the majority identified as stage $1(34 \%)$ and stage 4 (34\%) (Fig. 17). Other stages present were stage $0(3 \%)$, stage $2(12 \%)$, and stage 3 (18\%). Stage-0 males were collected from Station 303. Stage-1 males were collected from Stations 303, 306, 308, and 309. All male northern pike from Station 302 were stage 2, and stage- 2 males were collected from Stations 308 and 309. Stage-3 male northern pike were collected at Stations 304, 306,307 , and 310, and stage-4 males were collected from all stations except Station 302.

Basinwide mean GSI in male northern pike $(0.5 \%)$ was less than in female northern pike $(2.0 \%)$. GSI in male northern pike ranged from $0.3 \%$ at Stations 303 and 308 to $1.5 \%$ at Station 302 (Table 20). Stations 302 and 310 consistently had fish with GSI $>1.0 \%$, but these fish did not have GSI significantly greater than other stations (Fig. 19; Table 13). All male northern pike from Station 302 were stage 2 (mid-spermatogenic which includes spermatocytes, spermatids, and spermatozoa). Male northern pike from Station 310 with GSI $>1.0 \%$ were stage 3 (late spermatogenic in which mature sperm are predominant). Previous studies reporting GSI in male northern pike are limited. GSI ranged from 0.21 to $1.4 \%$ in male northern pike collected in September from the Missouri River near Garrison Dam, North Dakota (McDonald and others, 2002). Schmitt and others (2004) reported GSI of $0.2-4.2 \%$ in male northern pike collected in September-October from Alomosa, Colorado in the RGB. Gonadal stage of fish from these studies was not reported (McDonald and others, 2002; Schmitt and others, 2004).

Concentrations of vtg were measured in male northern pike; and many $(50 \%)$ were $<\mathrm{LOD}(0.001 \mathrm{mg} / \mathrm{mL})$. The basinwide mean of vtg in male northern pike was $0.014 \mathrm{mg} /$ $\mathrm{mL}$, and station means ranged from $<0.001 \mathrm{mg} / \mathrm{mL}$ at Station 307 to $0.097 \mathrm{mg} / \mathrm{mL}$ at Station 301 (Table 20; Fig. 19). Concentrations of vtg in northern pike $>$ LOD $(0.001 \mathrm{mg} / \mathrm{mL})$ were measured in fish at all stations except Stations 304, 305 


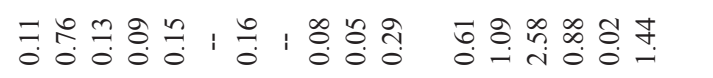

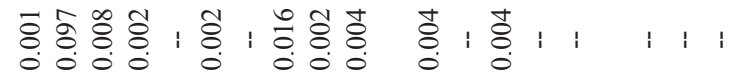

तై

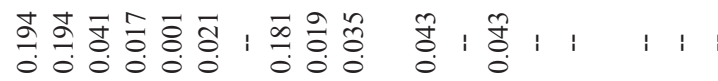

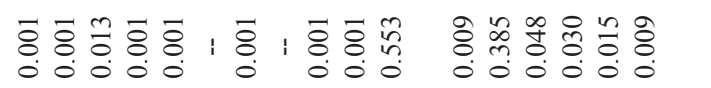

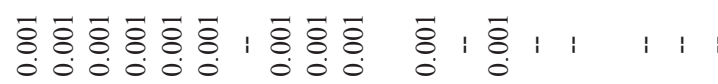

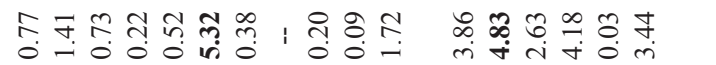

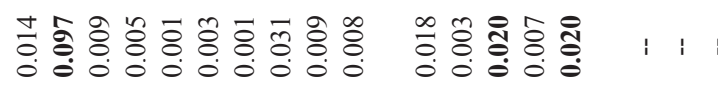

$\begin{array}{lllllllllllllllll}1 & 1 & 1 & 1 & 1 & 1 & 1 & 1 & 1 & 1 & 1 & 1 & 1 & 1 & 1 & 1 & 1\end{array}$

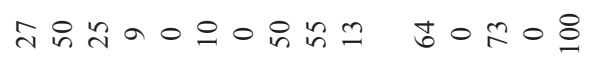

$n+n=n-a$ : $\infty a a \quad \delta=N \infty n r$ :

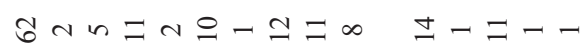

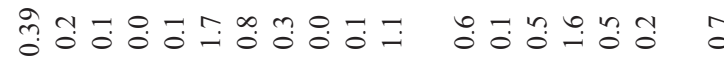

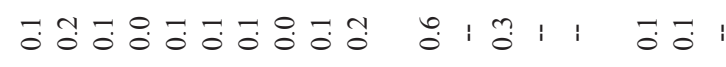

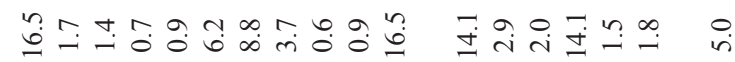

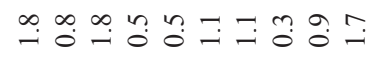

ஸे

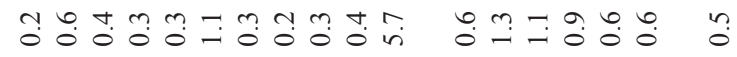

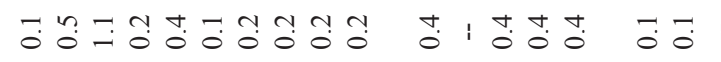

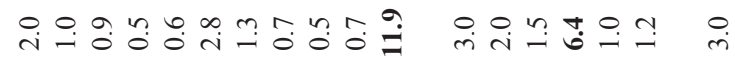

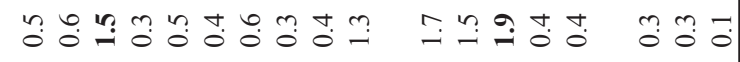

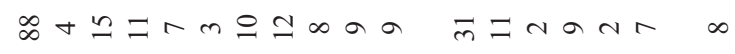

$\infty n+\exists n \subseteq \infty \simeq \approx \infty$

$\Xi-\Xi-\neg$

$n+-$

ब융

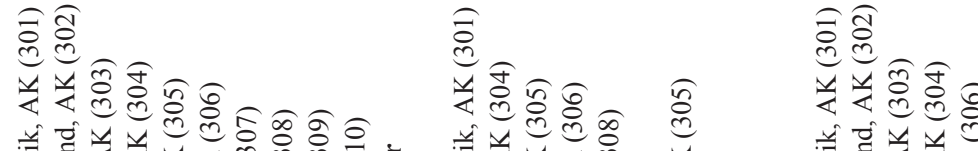

हृत् त्र

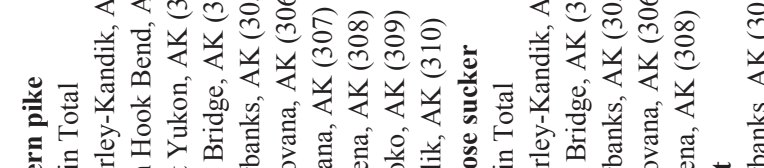

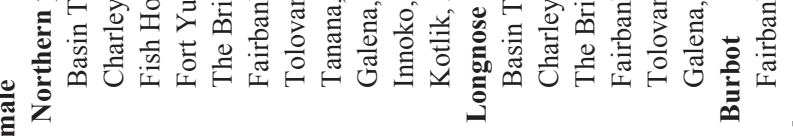

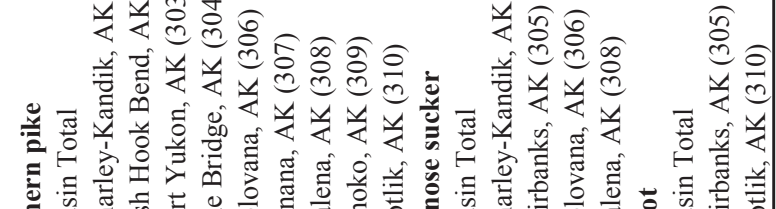

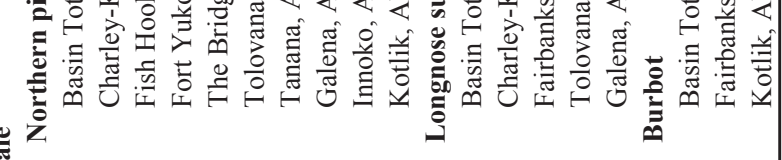




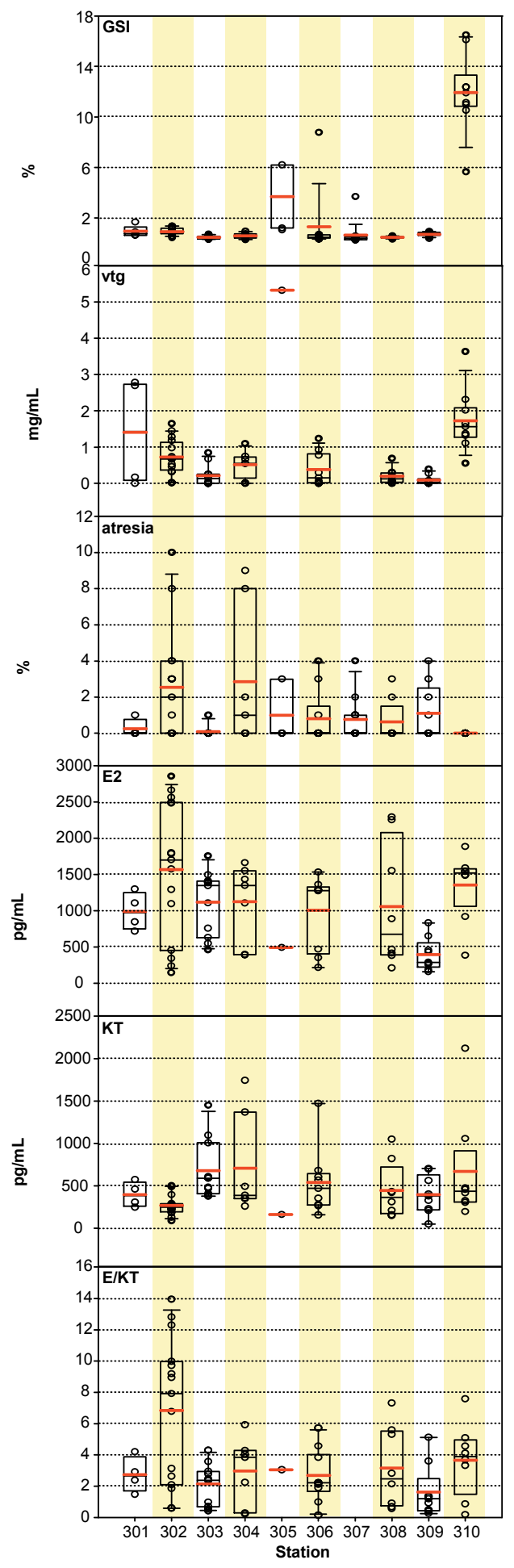

Figure 18. Reproductive health indicators by station in female northern pike collected in the Yukon River Basin in 2002. Indicators include gonadosomatic index (GSI), vitellogenin (vtg), atresia, estradiol (E2), 11-ketotestosterone (KT), and E/KT ratio. Shown for each group are points representing individual fish and the mean (red horizontal line), median (black horizontal line), interquartile range (box), and the 10th and 90th percentiles (whiskers). Stations are ordered upstream to downstream. See Table 1 for station descriptions. (no male northern pike collected), and 307. Individual male northern pike from all stations except Stations 304 and 307 had concentrations of $\mathrm{vtg}>0.01 \mathrm{mg} / \mathrm{mL}$ (Table 20). Multiple male northern pike from Stations 308 and 309 had concentrations of $\mathrm{vtg}>0.01 \mathrm{mg} / \mathrm{mL}$, and Stations 301 and 308 had male northern pike with concentrations of vtg $>0.10 \mathrm{mg} / \mathrm{mL}$ (Fig. 19). Concentrations of $v \operatorname{tg}>0.01 \mathrm{mg} / \mathrm{mL}$ indicate an estrogenic response in these male fish.

The basinwide mean concentration of KT in male northern pike was $933 \mathrm{pg} / \mathrm{mL}$, and the station means ranged from $408 \mathrm{pg} / \mathrm{mL}$ at Station 309 to $1,209 \mathrm{pg} / \mathrm{mL}$ at Station 302 (Table 21). Stations 309 and 302 also had the lowest and greatest concentrations of E2 in female northern pike, respectively. Station, stage, and gonadal stage influenced concentrations of KT in northern pike (Table 13). Male northern pike from Stations 306, 307, and 309 consistently had concentrations of $\mathrm{KT}<750 \mathrm{pg} / \mathrm{mL}$ and did not exceed 1,000 pg/mL (Fig. 19).

Concentrations of E2 were less than those of KT in most male northern pike. The basinwide mean concentration of E2 was $531 \mathrm{pg} / \mathrm{mL}$ in male northern pike (Table 21). Station means for E2 in male northern pike ranged from $139 \mathrm{pg} / \mathrm{mL}$ at Station 301 to 2,091 $\mathrm{pg} / \mathrm{mL}$ at Station $307(n=1)$ (Table 21). All other station means were $<936 \mathrm{pg} / \mathrm{mL}$ and did not differ significantly in concentrations of E2 (Fig. 19; Table 13). Stations $304,306,307,308$, and 310 had male northern pike with concentrations of $\mathrm{E} 2>1,000 \mathrm{pg} / \mathrm{mL}$. E/KT ratios in male northern pike ranged from 0.11 at Station 301 to 4.07 at Station 304 (Table 21; Fig. 19). Twenty-one percent of male northern pike, including individual fish from Stations 302, 304, 306, 308, 309, and 310, had E/KT ratios $>1.0$ and were in various stages of gonadal development (Fig. 19). Other studies evaluating steroid hormones concentrations in male northern pike were not found.

Gender of one northern pike from Station 309 was unable to be determined. This fish had a GSI of $0.3 \%$ and concentration of vtg of $0.007 \mathrm{mg} / \mathrm{mL}$. Concentrations of steroid hormones for this fish were $105 \mathrm{pg} / \mathrm{mL}$ for $\mathrm{E} 2,215 \mathrm{pg} / \mathrm{mL}$ for $\mathrm{KT}$, and the $\mathrm{E} / \mathrm{KT}$ ratio was 0.49 .

\section{Female Longnose Sucker}

Reproductive biomarker data were limited to five stations for longnose sucker (Fig. 20). Female longnose sucker were in stages $1(3 \%), 2(61 \%), 3(20 \%)$, and $5(16 \%)$. Stage was not correlated with capture date. Stage- 2 females were present at all five stations, and stage- 3 female longnose sucker were collected at Stations 305 and 308. Stage-1 female longnose sucker were found at Station 306, and stage- 5 females were identified at Stations 301 and 305.

Female longnose sucker had a basinwide mean of 3.0\% for GSI, and station means ranged from 1.0\% at Station 306 to $6.4 \%$ at Station 305 in the YRB (Table 20). Female longnose sucker from Station 305 consistently had GSI greater than other stations (Fig. 21; Table 13). However, all fish from 
Table 21. Arithmetic mean of estradiol (E2), Il-ketotestosterone (KT), and ratio of E/KT by gender, species, and station in northern pike, longnose sucker, and burobt collected in the Yukon River Basin in 2002. Number of samples ( $n$ ), minimum (min.), maximum (max.), and standard error (SE) are also given. Stations are ordered upstream to downstream. The maximum station mean for each taxon is shown in bold. Only individual fish with histologically determined gender were included in this table.

\begin{tabular}{|c|c|c|c|c|c|c|c|c|c|c|c|c|c|}
\hline \multirow{2}{*}{ Gender, Species, and Station } & \multicolumn{3}{|c|}{ E2 $(\mathrm{pg} / \mathrm{mL})$} & \multirow[b]{2}{*}{ Max. } & \multirow[b]{2}{*}{$\mathrm{SE}$} & \multicolumn{4}{|c|}{$\mathrm{KT}(\mathrm{pg} / \mathrm{mL})$} & \multicolumn{4}{|l|}{$\mathrm{E} / \mathrm{KT}$} \\
\hline & $n$ & Mean & Min. & & & Mean & Min. & Max. & $\mathrm{SE}$ & Mean & Min. & Max. & $\mathrm{SE}$ \\
\hline \multicolumn{14}{|l|}{ Female } \\
\hline \multicolumn{14}{|l|}{ Northern pike } \\
\hline Basin Total & 72 & 1111 & 145 & 2852 & 82 & 494 & 51 & 2121 & 46 & 3.53 & 0.15 & 13.95 & 0.37 \\
\hline Charley-Kandik, AK (301) & 4 & 991 & 717 & 1297 & 130 & 398 & 247 & 573 & 74 & 2.74 & 1.47 & 4.20 & 0.57 \\
\hline Fish Hook Bend, AK (302) & 15 & 1565 & 145 & 2852 & 244 & 270 & 89 & 503 & 30 & 6.83 & 0.59 & 13.95 & 1.20 \\
\hline Fort Yukon, AK (303) & 11 & 1117 & 461 & 1756 & 134 & 679 & 376 & 1449 & 106 & 2.13 & 0.43 & 4.30 & 0.39 \\
\hline The Bridge, AK (304) & 7 & 1126 & 389 & 1664 & 201 & 708 & 262 & 1741 & 224 & 2.98 & 0.22 & 5.91 & 0.81 \\
\hline Fairbanks, AK (305) & 1 & 493 & -- & -- & -- & 162 & -- & -- & -- & 3.04 & -- & -- & -- \\
\hline Tolovana, AK (306) & 9 & 1005 & 216 & 1532 & 169 & 540 & 158 & 1471 & 130 & 2.64 & 0.15 & 5.72 & 0.59 \\
\hline Tanana, AK (307) & 0 & -- & -- & -- & -- & -- & -- & -- & -- & -- & -- & -- & -- \\
\hline Galena, AK (308) & 8 & 1057 & 211 & 2292 & 304 & 444 & 148 & 1049 & 116 & 3.16 & 0.57 & 7.31 & 0.91 \\
\hline Innoko, AK (309) & 9 & 393 & 160 & 832 & 75 & 397 & 51 & 705 & 74 & 1.63 & 0.26 & 5.12 & 0.55 \\
\hline Kotlik, AK (310) & 8 & 1355 & 384 & 1884 & 168 & 670 & 197 & 2121 & 227 & 3.67 & 0.18 & 7.58 & 0.83 \\
\hline \multicolumn{14}{|l|}{ Longnose sucker } \\
\hline Basin Total & 31 & 1402 & 467 & 2748 & 106 & 361 & 118 & 782 & 31 & 5.27 & 0.73 & 18.53 & 0.77 \\
\hline Charley-Kandik, AK (301) & 11 & 1126 & 513 & 1786 & 137 & 379 & 163 & 585 & 42 & 3.49 & 0.88 & 9.07 & 0.66 \\
\hline The Bridge, AK (304) & 2 & 1214 & 1106 & 1321 & 108 & 298 & 178 & 417 & 120 & 4.69 & 3.17 & 6.21 & 1.52 \\
\hline Fairbanks, AK (305) & 9 & 1630 & 834 & 2748 & 190 & 363 & 118 & 644 & 58 & 5.96 & 1.30 & 18.53 & 1.65 \\
\hline Tolovana, AK (306) & 2 & 1332 & 467 & 2197 & 865 & 440 & 241 & 638 & 199 & 4.92 & 0.73 & 9.12 & 4.19 \\
\hline Galena, AK (308) & 7 & 1618 & 882 & 2725 & 249 & 327 & 126 & 782 & 85 & 7.46 & 1.13 & 17.47 & 2.11 \\
\hline \multicolumn{14}{|l|}{ Burbot } \\
\hline Fairbanks, AK (305) & 8 & 534 & 115 & 1720 & 215 & 303 & 145 & 776 & 81 & 1.46 & 0.66 & 2.38 & 0.22 \\
\hline \multicolumn{14}{|l|}{ Male } \\
\hline \multicolumn{14}{|l|}{ Northern pike } \\
\hline Basin Total & 61 & 531 & 102 & 2588 & 62 & 933 & 91 & 2149 & 71 & 1.32 & 0.07 & 28.44 & 0.48 \\
\hline Charley-Kandik, AK (301) & 2 & 139 & 102 & 175 & 37 & 1209 & 1171 & 1246 & 38 & 0.11 & 0.09 & 0.14 & 0.03 \\
\hline Fish Hook Bend, AK (302) & 5 & 305 & 135 & 513 & 82 & 1127 & 191 & 1886 & 345 & 0.53 & 0.07 & 1.04 & 0.22 \\
\hline Fort Yukon, AK (303) & 11 & 448 & 115 & 835 & 67 & 1208 & 717 & 1677 & 100 & 0.36 & 0.10 & 0.50 & 0.04 \\
\hline The Bridge, AK (304) & 2 & 936 & 775 & 1096 & 161 & 877 & 143 & 1610 & 734 & 4.07 & 0.48 & 7.66 & 3.59 \\
\hline Tolovana, AK (306) & 9 & 489 & 134 & 1957 & 202 & 603 & 342 & 911 & 69 & 0.99 & 0.19 & 3.45 & 0.40 \\
\hline Tanana, AK (307) & 1 & 2091 & -- & -- & -- & 548 & -- & -- & -- & 3.82 & -- & -- & -- \\
\hline Galena, AK (308) & 12 & 796 & 170 & 2588 & 188 & 1206 & 91 & 2149 & 215 & 3.07 & 0.08 & 28.44 & 2.32 \\
\hline Innoko, AK (309) & 11 & 355 & 102 & 894 & 85 & 408 & 184 & 703 & 60 & 1.11 & 0.17 & 4.86 & 0.39 \\
\hline Kotlik, AK (310) & 8 & 478 & 239 & 1039 & 90 & 1108 & 765 & 1573 & 93 & 0.48 & 0.25 & 1.29 & 0.13 \\
\hline \multicolumn{14}{|l|}{ Longnose sucker } \\
\hline Basin Total & 14 & 632 & 152 & 2515 & 212 & 755 & 131 & 1518 & 148 & 1.51 & 0.11 & 7.17 & 0.56 \\
\hline Eagle, AK (301) & 1 & 246 & -- & -- & -- & 642 & -- & -- & -- & 0.38 & -- & -- & -- \\
\hline Fairbanks, AK (305) & 11 & 533 & 152 & 2515 & 201 & 848 & 178 & 1518 & 176 & 1.22 & 0.11 & 7.17 & 0.61 \\
\hline Nenana, AK (306) & 1 & 2459 & -- & -- & -- & 468 & -- & -- & -- & 5.25 & -- & -- & -- \\
\hline Galena, AK (308) & 1 & 278 & -- & -- & -- & 131 & -- & -- & -- & 2.12 & -- & -- & -- \\
\hline \multicolumn{14}{|l|}{ Burbot } \\
\hline Basin Total & 5 & 646 & 105 & 1390 & 214 & 1082 & 235 & 1686 & 245 & 1.49 & 0.08 & 5.91 & 1.11 \\
\hline Fairbanks, AK (305) & 4 & 658 & 105 & 1390 & 276 & 932 & 235 & 1356 & 249 & 1.78 & 0.08 & 5.91 & 1.39 \\
\hline Kotlik, AK (310) & 1 & 596 & -- & -- & -- & 1686 & -- & -- & -- & 0.35 & -- & -- & -- \\
\hline
\end{tabular}

Station 305 with GSI $>8.0 \%$ were stage 3 (late vitellogenic follicles), a gonadal stage in which high GSI values are typical. Longnose sucker from the CRB had GSI ranging from 0.6 to $12.4 \%$ but gonadal stage was not determined (Hinck and others, 2004).

Female and male longnose sucker were examined separately for vtg although gender did not influence vtg concentrations in the YRB (Table 13). The basinwide mean of vtg in female longnose sucker was $3.86 \mathrm{mg} / \mathrm{mL}$, and station means ranged from $0.03 \mathrm{mg} / \mathrm{mL}$ at Station 306 to $4.83 \mathrm{mg} / \mathrm{mL}$ at Station 301 (Table 20). Female longnose sucker from Stations 301,305 , and 308 with concentrations of $v \operatorname{tg}>7.0 \mathrm{mg} / \mathrm{mL}$ were stage-2 and -3 fish. Most female longnose sucker (67\%) had concentrations of vtg between 0.4 and $7.4 \mathrm{mg} / \mathrm{mL}$ (Fig. 21). Concentrations of vtg in longnose sucker from near Cres- ton, Montana (0.0-63.6 mg/mL) and Grand Coulee, Washington $(4.1 \mathrm{mg} / \mathrm{mL})$ in the upper CRB (Hinck and others, 2004) were greater than concentrations in YRB longnose sucker. Concentrations of vtg in female largescale sucker from the CRB had a basinwide mean of $38.8 \mathrm{mg} / \mathrm{mL}$, and station means ranged from $14.1 \mathrm{mg} / \mathrm{mL}$ near Grand Coulee, Washington to $66.5 \mathrm{mg} / \mathrm{mL}$ near Oregon City, Oregon (Hinck and others, 2004). Other studies reporting concentrations of plasma vtg in female longnose sucker were not found.

Mean percent atresia data in longnose sucker were limited for YRB stations. Basinwide mean percent atresia was $0.0 \%$, and station means ranged from $0.0 \%$ at Stations 304 and 305 to $0.5 \%$ at Stations 301 and 306 (Table 20). Two longnose sucker from Station 301 had atresia $>2 \%$ (Fig. 21). YRB station means did not differ significantly for percent atresia 


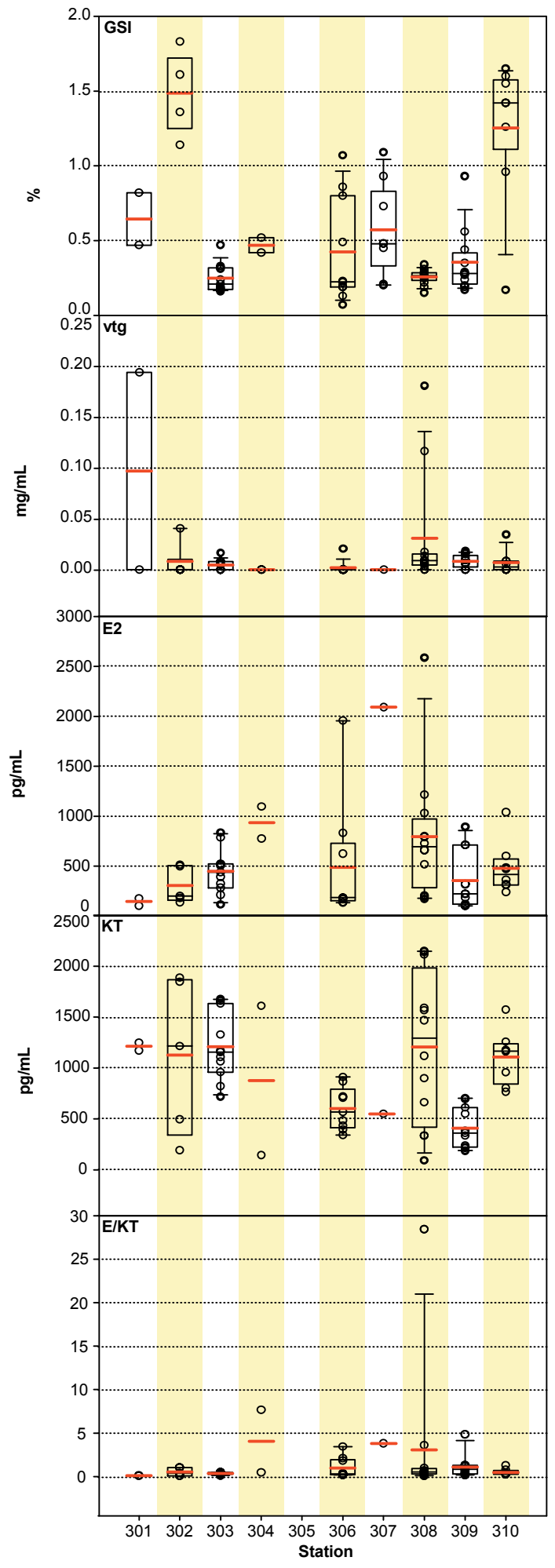

Figure 19. Reproductive health indicators by station in male northern pike collected in the Yukon River Basin in 2002. Indicators include gonadosomatic index (GSI), vitellogenin (vtg), estradiol (E2), 11-ketotestosterone (KT), and E/KT ratio. Shown for each group are points representing individual fish and the mean (red horizontal line), median (black horizontal line), interquartile range (box), and the 10th and 90th percentiles (whiskers). Stations are ordered upstream to downstream. See Table 1 for station descriptions.
(Table 13). Similar percent atresia was reported in largescale sucker from the CRB (Hinck and others, 2004). No other studies evaluating percent atresia in longnose sucker were located.

Female and male longnose sucker were examined separately for steroid hormones because gender influenced concentrations of E2 and E/KT ratio (Table 13). The basinwide mean of E2 in female longnose sucker $(1,402 \mathrm{pg} / \mathrm{mL})$ was greater than in female northern pike $(1,111 \mathrm{pg} / \mathrm{mL})$ (Table 21). Station means for concentrations of $E 2$ in female longnose sucker ranged from $1,126 \mathrm{pg} / \mathrm{mL}$ at Station 301 to 1,630 $\mathrm{pg} / \mathrm{mL}$ at Station 305 and did not vary significantly among stations (Tables 13 and 21). Concentrations of E2 were $>2,000$ $\mathrm{pg} / \mathrm{mL}$ in female longnose sucker from Stations 305, 306, and 308 (Fig. 21). Female northern pike from Station 308 also had concentrations of E2 $>2,000 \mathrm{pg} / \mathrm{mL}$ (Table 21). Most female longnose sucker (81\%) had concentrations of E2 between 500 and 2,000 pg/mL (Fig. 21).

Concentrations of KT were less than those of E2 in most female longnose sucker. The basinwide mean concentration of KT in female longnose sucker was $361 \mathrm{pg} / \mathrm{mL}$ (Table 21). Station means for KT ranged from $298 \mathrm{pg} / \mathrm{mL}$ at Station 304 to $440 \mathrm{pg} / \mathrm{mL}$ at Station 306, which were less than concentrations of KT measured in female northern pike (Table 21). Station means for concentrations of KT in female longnose sucker were $<1,000 \mathrm{pg} / \mathrm{mL}$ (Table 21) and did not differ significantly (Fig. 21; Table 13). Mean E/KT ratios ranged from 3.49 at Station 301 to 7.46 at Station 308, and only two female longnose sucker (6\%) from Stations 301 and 306 had E/KT ratios $<1.0$ (Fig. 21). Other studies reporting concentrations of steroid hormones in female longnose sucker were not found.

\section{Male Longnose Sucker}

Male longnose sucker were collected from only four stations in the YRB; therefore, the reproductive stage data was limited $(n=14)$ (Fig. 20). Male longnose sucker were identified as stage $0(14 \%)$, stage $1(29 \%)$ and stage $3(57 \%)$.

Basinwide mean GSI in male longnose sucker (1.7\%) was less than in female longnose sucker (3.0\%). Station means for GSI in male longnose sucker ranged from $0.4 \%$ at Stations 306 and 308 to $1.9 \%$ at Station $305(n=1)$ (Table 20; Fig. 22). Male longnose sucker with GSI $>1 \%$ at Station 305 were identified as stage 3 . GSI in male longnose sucker did not vary significantly among YRB stations (Table 13). Two longnose sucker from the upper CRB had GSI of 5.2\% and $5.3 \%$, although gonadal stage was not determined (Hinck and others, 2004).

Concentrations of vtg were $>\operatorname{LOD}(0.001 \mathrm{mg} / \mathrm{mL})$ in $93 \%$ of male longnose sucker. The basinwide mean of vtg in male longnose sucker was $0.018 \mathrm{mg} / \mathrm{mL}$, and station means ranged from $0.003 \mathrm{mg} / \mathrm{mL}$ at Station 301 to $0.020 \mathrm{mg} / \mathrm{mL}$ at Stations 305 and 308 (Table 20, Fig. 22). Multiple male longnose sucker $(73 \%)$ from Station 305 had concentrations of vtg $>0.01 \mathrm{mg} / \mathrm{mL}$ (Table 20). These results may warrant further 


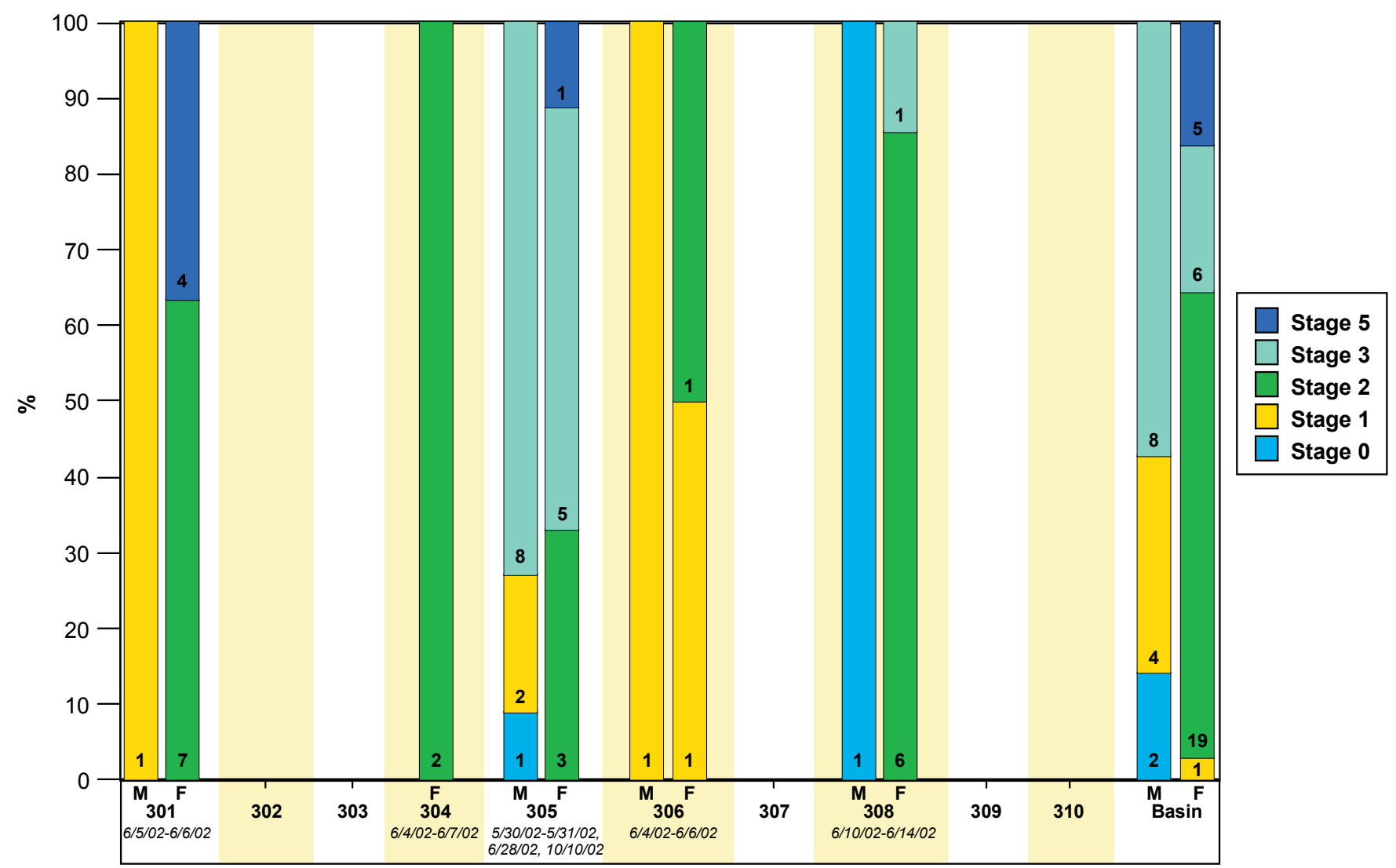

Station

Figure 20. Gonadal stage of female and male longnose sucker collected in the Yukon River Basin in 2002. Shown are the percentages ( $y$-axis) and sample sizes (within the bars) of fish in each stage. The collection dates for each station are also shown. Stations are ordered upstream to downstream. See Table 1 for station descriptions.

investigation of endocrine modulating chemicals at this site. Concentrations of vtg in longnose sucker collected near Creston, Montana $(0.006 \mathrm{mg} / \mathrm{mL})$ and Grand Coulee, Washington $(<0.005 \mathrm{mg} / \mathrm{mL})$ were similar to concentrations in YRB longnose sucker (Hinck and others, 2004). The basinwide mean concentration of vtg in male largescale sucker from the CRB was $0.016 \mathrm{mg} / \mathrm{mL}$, and station means ranged from $<0.005$ to $0.05 \mathrm{mg} / \mathrm{mL}$ (Hinck and others, 2004). Other studies examining vtg in male longnose sucker were not located.

The basinwide mean of KT in male longnose sucker was $755 \mathrm{pg} / \mathrm{mL}$, and station means ranged from $131 \mathrm{pg} / \mathrm{mL}$ at Station 308 to $848 \mathrm{pg} / \mathrm{mL}$ at Station 305 (Table 21). Concentrations of KT in male longnose sucker did not vary significantly among stations (Table 13). Several male longnose sucker from Station 305 had concentrations of KT >1,200 pg/mL (Fig. 22).

Concentrations of E2 were less than those of KT in most male longnose sucker. The basinwide mean was $632 \mathrm{pg} / \mathrm{mL}$ in male longnose sucker, and station means for E2 ranged from $246 \mathrm{pg} / \mathrm{mL}$ at Station 301 to 2,459 pg/mL at Station 306 (Table 21). Stations did not vary significantly in concentrations of E2 in male longnose sucker (Fig. 22; Table 13). Two male longnose sucker from Stations 305 and 306 had concentrations of E2 >2,000 pg/mL (Fig. 22). Station mean E/KT ratios ranged from 0.38 at Station 301 to 5.25 at Station 306, and male longnose sucker (29\%) from Stations 306, 306, and 308 had E/KT ratios $>1.0$ (Fig. 22). Other studies evaluating steroid hormones in male longnose sucker were not found.

One longnose sucker, with no preserved gonad from Station 305, had a GSI of $0.54 \%$ and a concentration of vtg of $0.004 \mathrm{mg} / \mathrm{mL}$. Concentrations of E2 and KT for this fish were $206 \mathrm{pg} / \mathrm{mL}$ and $241 \mathrm{pg} / \mathrm{mL}$ of $\mathrm{KT}$, respectively resulting in an $\mathrm{E} / \mathrm{KT}$ ratio of 0.85 .

\section{Reproductive Biomarker: Summary}

The reproductive biomarkers used in this study including gonadal histopathology, GSI, vtg, and steroid hormones are the best techniques available for measuring reproductive function as well as the effects of contaminants, whether endocrine disrupting or on general reproductive health. Age, species, water temperature, photoperiod, and other biotic and abiotic factors can influence these biomarkers and can cause great fluctuations during the reproductive cycle. Designing a study to control for these variables may provide valuable data 


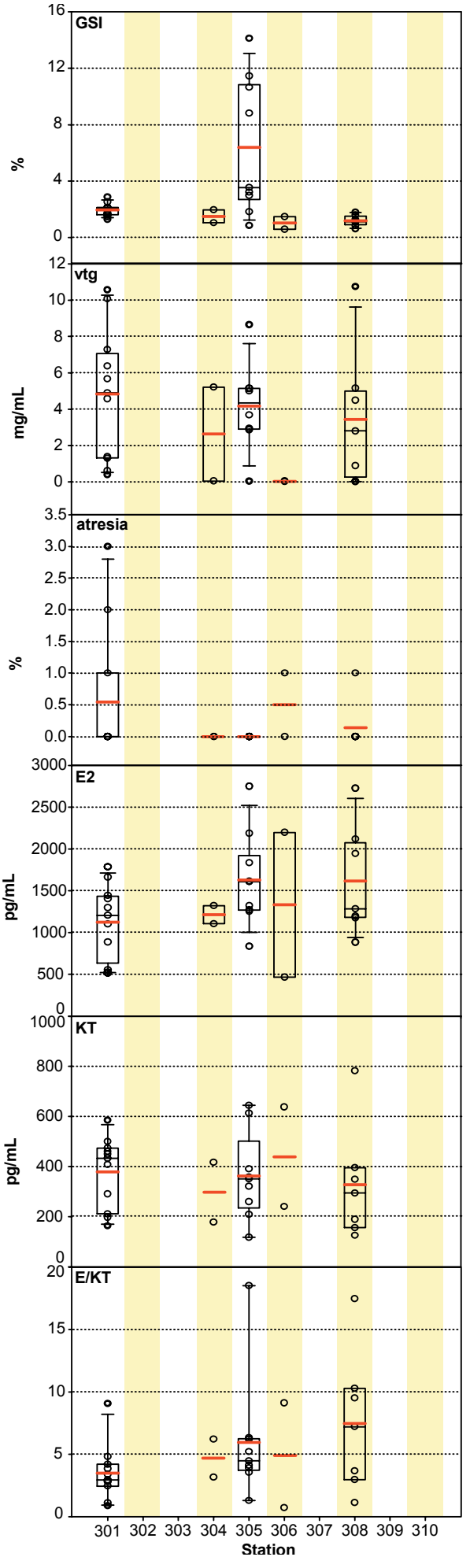

Figure 21. Reproductive health indicators by station in female longnose sucker collected in the Yukon River Basin in 2002. Indicators include gonadosomatic index (GSI), vitellogenin (vtg), atresia, estradiol (E2), 11-ketotestosterone (KT), and E/KT ratio. Shown for each group are points representing individual fish and the mean (red horizontal line), median (black horizontal line), interquartile range (box), and the 10th and 90th percentiles (whiskers). Stations are ordered upstream to downstream. See Table 1 for station descriptions.

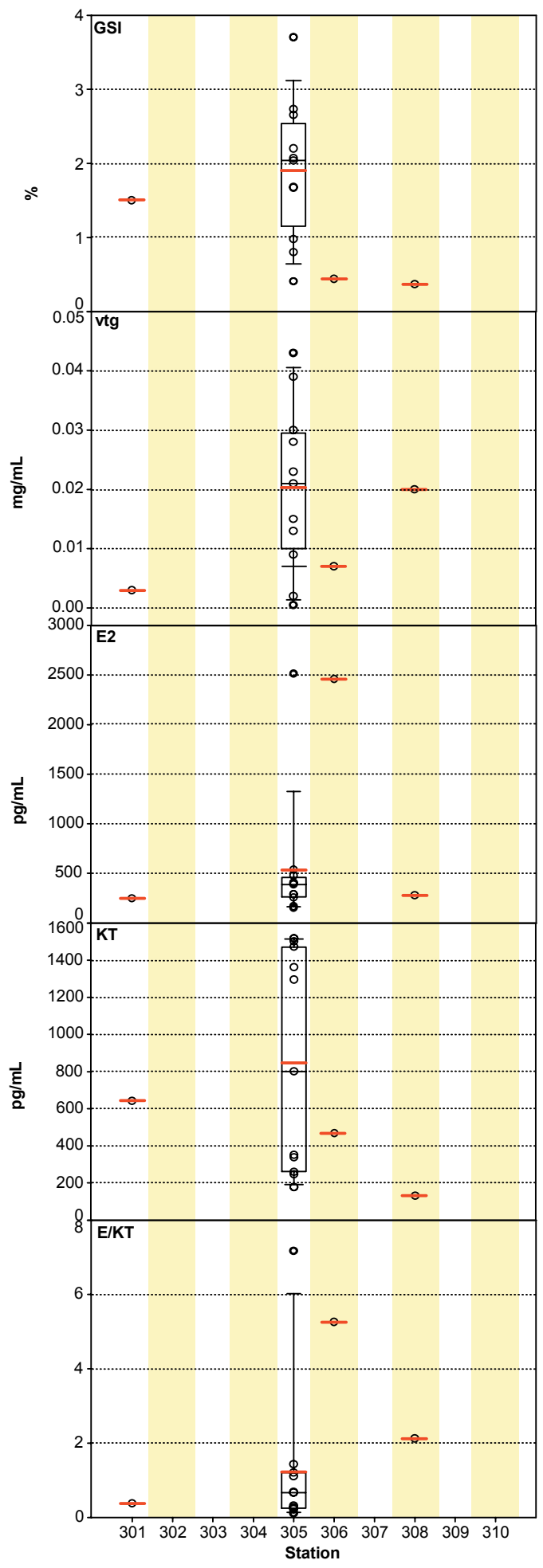

Figure 22. Reproductive health indicators by station in male longnose sucker collected in the Yukon River Basin in 2002. Indicators include gonadosomatic index (GSI), vitellogenin (vtg), estradiol (E2), 11-ketotestosterone (KT), and E/KT ratio. Shown for each group are points representing individual fish and the mean (red horizontal line), median (black horizontal line), interquartile range (box), and the 10th and 90th percentiles (whiskers). Stations are ordered upstream to downstream. See Table 1 for station descriptions. 
and important insights into reproductive health. A variety of laboratory studies, as well as several field studies designed to monitor the effects of environmental contaminants on the reproductive activity, have proven these biomarkers to be valuable measures of reproductive activity and dysfunction. The use of this suite of reproductive biomarkers is necessary to evaluate the effects of contaminants on reproductive health and will continue to be incorporated into the BEST LRMN projects.

GSI is often used to evaluate reproductive status and health, although interpretations of GSI measurements rely on understanding natural variations among fish of the same age, gender, and species. Environmental influence and behavioral patterns may also confound the data. Considerable variations in gonad size have been reported throughout the reproductive cycle of many animal species (de Vlaming and others, 1981). Northern pike from Station 310 consistently had GSI (>10\%) greater than other stations; however, all northern pike were stage- 4 and greater GSI are expected. Fish from Station 310 were collected earlier (early May) than the other stations (June to October). Individual fish from Station 302 had the greatest GSI (1.5\%) for male northern pike and were identified as stage-3 (late spermatogenic). Female and male longnose sucker from Station 305 had the greatest GSI (6.4\% and $1.9 \%$, respectively) in the YRB.

Gonadal histopathology was used to confirm gender, assign reproductive stage, and detect anatomical abnormalities such as the presence of ovotestis and excessive oocyte atresia. Gonadal stage varied between genders and stations, most likely a result of collection date. Stage was given close attention in the interpretation of these data because the reproductive biomarkers used in this study are known to vary over the course of the reproductive cycle. Ovotestes were not found in any fish from the YRB examined histologically, although a previous study reported ovotestis in northern pike from a Missouri River reservoir (June, 1977).

Oocyte atresia is defined as the involution or resorption of oocytes by the ovaries and has been sufficiently validated as a histological biomarker. Although oocyte atresia is a normal physiological event in all fish, it can become a pathological condition following exposure to certain environmental contaminants (Cross and Hose, 1988; 1989; Johnson and others, 1988; Kirubagaran and Joy, 1988). Several studies had examined oocyte atresia in northern pike (June, 1970; 1977), but no studies were located for longnose sucker. Mean percent atresia was low in northern pike and longnose sucker and varied little among stations (Table 20). Oocyte atresia in northern pike and longnose sucker in the YRB did not indicate exposure to environmental contaminants.

Relatively low concentrations of vtg were measured in both northern pike and longnose sucker in the YRB. Concentrations of vtg in female northern pike were similar among stations with most fish having concentrations $<3.0 \mathrm{mg} / \mathrm{mL}$. Female longnose sucker had greater concentrations of vtg (most ranging from 2 to $10 \mathrm{mg} / \mathrm{mL}$ ) compared to female northern pike. Other studies have localized vtg receptors to the testes, muscle, and spermatocytes (Bidwell and Carlson, 1995; Tao and others, 1996). A 1995 reconnaissance study by Goodbred and others (1997) reported detectable concentrations of vtg in males from a reference site and confirmed the fact that small amounts of vtg can be present in healthy males. Vitellogenin was measured in male northern pike from all stations except Stations 304, 305 (no male northern pike collected), and 307; concentrations of vtg were $<0.20 \mathrm{mg} / \mathrm{mL}$. Male northern pike from Stations 301 and 308 had the greatest concentrations of vtg $(>0.1 \mathrm{mg} / \mathrm{mL})$. Male longnose sucker from Stations 305, 306, and 307 had concentrations of vtg $>0.05 \mathrm{mg} / \mathrm{mL}$. Concentrations of vtg were not correlated with stage and did not differ significantly among stages for fish collected in the YRB.

$\mathrm{E} 2, \mathrm{KT}$, and $\mathrm{E} / \mathrm{KT}$ were examined in northern pike and longnose sucker from the YRB to determine if chemical compounds were affecting steroid hormones concentrations. Like many of the other reproductive biomarkers, concentrations of steroid hormones can vary by gender, age, geographical locations, species, and season (Barry and others, 1990; Bromage and others, 1982; Chang and Chen, 1990; Denslow and others, 1999; Down and others, 1990; Goodbred and others, 1997; So and others, 1989); therefore, interpretation of hormone data requires knowledge of all of these factors. Other studies reporting steroid hormone data in northern pike and longnose sucker were not found; therefore, "normal" concentrations of steroid hormones in these species cannot be determined. However, E/KT ratios $>1.0$ for females and $<1.0$ for males are generally considered normal (Folmar and others, 1996; Hileman, 1994). Female northern pike from all stations except Station 301 had individual fish with $\mathrm{E} / \mathrm{KT}$ ratios $<1.0$, and male northern pike from all stations except Stations 301 and 303 had E/KT ratios $>1.0$ (Table 21). Gonadal stage did not influence steroid hormone concentrations in northern pike. Individual female longnose sucker from Stations 301 and 306 had $\mathrm{E} / \mathrm{KT}$ ratios $<1.0$, and male longnose sucker from Stations 305,306 , and 307 had E/KT ratios $>1.0$ although sample sizes were limited (Table 21). Unlike northern pike, gonadal stage influenced steroid hormone concentrations in longnose sucker. The variation in hormones concentrations within each species was expected because of the various factors that influence these reproductive biomarkers and has been reported in others species (McDonald and others, 2002).

\section{Spatial patterns in contaminant concentrations and biomarker responses}

\section{Geographic Summaries}

Geographic station summaries were made to highlight elevated contaminant concentrations and/or biomarker responses or both (Table 22). The highlighted findings indicate contaminant concentrations or EROD levels that exceeded 
known thresholds or were anomalous (that is, high or low) relative to other YRB stations. The colors for the reproductive and fish health biomarkers are relative and indicate the number and/or magnitude of the anomalies (including the number of gender-species categories in which they occurred) at a station. The summaries are intended only to draw attention to particular stations highlighted in the text, possibly for further investigation. It is important to recognize that increased frequencies of external lesions or elevated HAI scores, which represent the cumulative total number of grossly visible internal and external lesions, do not necessarily indicate direct contaminant effects. Many factors other than contaminants can indirectly influence fish health indicators and reproductive biomarkers, including nutrients or organic matter and water temperature. Considerably more is known about risk to fish and piscivorous wildlife associated with bioaccumulative contaminants and EROD than about long- and short-term risks represented by the other biomarkers. Therefore, greater relative risk has been associated with elevated contaminant concentrations and EROD rates than with anomalous fish health or reproductive biomarkers (Table 22; Figs. 23-25).

\section{Station 301 (Near Charley-Kandik confluence, AK)}

Station 301 was located near the confluence of the Charley and Kandik Rivers with the Yukon River near the Canadian border. Female and male northern pike and longnose sucker were collected in early June 2002. Few contaminants and biomarkers exceeded threshold criteria or appeared anomalous in fish at this site (Table 22). The concentration of Se in male northern pike $(0.66 \mu \mathrm{g} / \mathrm{g} \mathrm{ww})$ and female longnose sucker $(0.62 \mu \mathrm{g} / \mathrm{g} \mathrm{ww})$ exceeded guidelines to protect fish and piscivorous wildlife (Fig. 23; Lemly, 1996). Male and female northern pike and female longnose sucker had the greatest station mean EROD activity in the YRB. Even so,
EROD activity sample sizes were small at Station 301, and other stations had individual fish with greater EROD activities. Only two fish health indicators and reproductive biomarkers were highlighted at Station 301 (Table 22). Mean SSI in male northern pike $(0.18 \%)$ was the greatest in the YRB. A male northern pike had the greatest concentration of vtg (0.194 $\mathrm{mg} / \mathrm{mL}$ ) measured in the YRB (Fig. 24), suggesting this fish may have been exposed to endocrine-modulating chemicals. Multiple contaminants and biomarkers were highlighted in male northern pike from Station 301; however, only two male northern pike were collected and caution should be used when interpreting these data.

\section{Station 302 (Fish Hook Bend, AK)}

Station 302 was located near Fish Hook Bend on the upper Porcupine River. Male and female northern pike were collected from this site in mid-August 2002. Selenium was the only contaminant of concern at this station. Concentrations of Se in male $(0.72 \mu \mathrm{g} / \mathrm{g} \mathrm{ww})$ and female $(0.73 \mu \mathrm{g} / \mathrm{g} \mathrm{ww})$ northern pike exceeded guidelines to protect fish and piscivorous wildlife (Fig. 23; Lemly, 1996). Fish health indicators were not anomalous in fish from this station. Atresia was the only reproductive biomarker highlighted (Table 22). Two female northern pike had atresia $\geq 8 \%$ whereas the others had $\leq 4 \%$; all female northern pike from this site were stage 2 . The differences in the atresia data from this site could be a result of normal, natural variation in northern pike.

\section{Station 303 (Fort Yukon, AK)}

Station 303 was located on the lower Porcupine River upstream of its confluence with the Yukon River. Male and female northern pike were collected from this site in mid-June 2002. Concentrations in northern pike did not exceed thresh-

Table 22. Summary of chemical and biological indicator results by Yukon River Basin station. Within each column, colors indicate the severity, prevalence, or both of the indicated condition or conditions at each station (green<yellow<red). These designations are relative; see text for explanations. Male and female northern pike ( $p$ ), longnose sucker ( $s$ ), and burbot (b) were collected from all sites unless otherwise indicated. See Table 3 and Figure 1 for station locations. Bold lettering denotes that threshold criteria were exceeded and/or high incidence of elevated occurrence. $\mathrm{Hg}$, mercury; Se, selenium; EROD, ethoxyresorufin $\mathrm{O}$-deethylase; EL, external lesions; SSI, splenosomatic index; HAI, health assessment index; MA, macrophage aggregates (one or more parameters); vtg, vitellogenin; E/KT, estradiol/11-ketotestosterone ratio; m, male; f, female. For SSI, - indicates smaller; all others larger.

\begin{tabular}{|c|c|c|c|c|}
\hline Station & Species Collected & Contaminants and EROD & $\begin{array}{l}\text { Fish Health } \\
\text { Indicators }\end{array}$ & $\begin{array}{l}\text { Reproductive } \\
\text { Biomarkers }\end{array}$ \\
\hline Charley-Kandik, AK (301) & $\mathrm{p}, \mathrm{s}$ & Se (mp,fs), EROD (mp,fp,fs) & SSI (mp) & vtg (mp) \\
\hline Fish Hook Bend, AK (302) & $\mathrm{p}$ & Se (mp,fp) & & atresia (fp) \\
\hline Fort Yukon, AK (303) & $\mathrm{p}$ & & EL (p), HAI (p) & E/KT (fp) \\
\hline The Bridge, AK (304) & $p, f s$ & $\mathrm{Hg}(\mathrm{mp}, \mathrm{fp}), \mathrm{Se}(\mathrm{fs})$ & & atresia (fp), E/KT (mp,fp) \\
\hline Fairbanks, AK (305) & $\mathrm{fp}, \mathrm{s}, \mathrm{b}$ & $\mathrm{Hg}(\mathrm{mb}), \mathrm{Se}(\mathrm{mb}, \mathrm{fb}, \mathrm{fs})$ & & $\operatorname{vtg}(\mathrm{ms}), \mathrm{E} / \mathrm{KT}(\mathrm{ms})$ \\
\hline Tolovana, AK (306) & $\mathrm{p}, \mathrm{s}$ & $\mathrm{Hg}(\mathrm{fp})$ & SSI (fp, $-\mathrm{s})$, MA (p) & $\mathrm{E} / \mathrm{KT}(\mathrm{mp}, \mathrm{fp}, \mathrm{ms})$ \\
\hline Tanana, AK (307) & $\mathrm{p}$ & $\mathrm{Hg}(\mathrm{mp}, \mathrm{fp})$ & HAI (p) & \\
\hline Galena, AK (308) & $\mathrm{p}, \mathrm{s}$ & $\mathrm{Hg}(\mathrm{mp}, \mathrm{fp})$ & SSI (fp) & $\operatorname{vtg}(\mathrm{mp}, \mathrm{ms}), \mathbf{E} / \mathbf{K T}(\mathrm{mp})$ \\
\hline Innoko, AK (309) & $\mathrm{p}$ & & & $\operatorname{vtg}(\mathrm{mp}), \mathrm{E} / \mathrm{KT}(\mathrm{fp})$ \\
\hline Kotlik, AK (310) & $\mathrm{p}, \mathrm{mb}$ & & & $\mathrm{E} / \mathrm{KT}(\mathrm{fp})$ \\
\hline
\end{tabular}



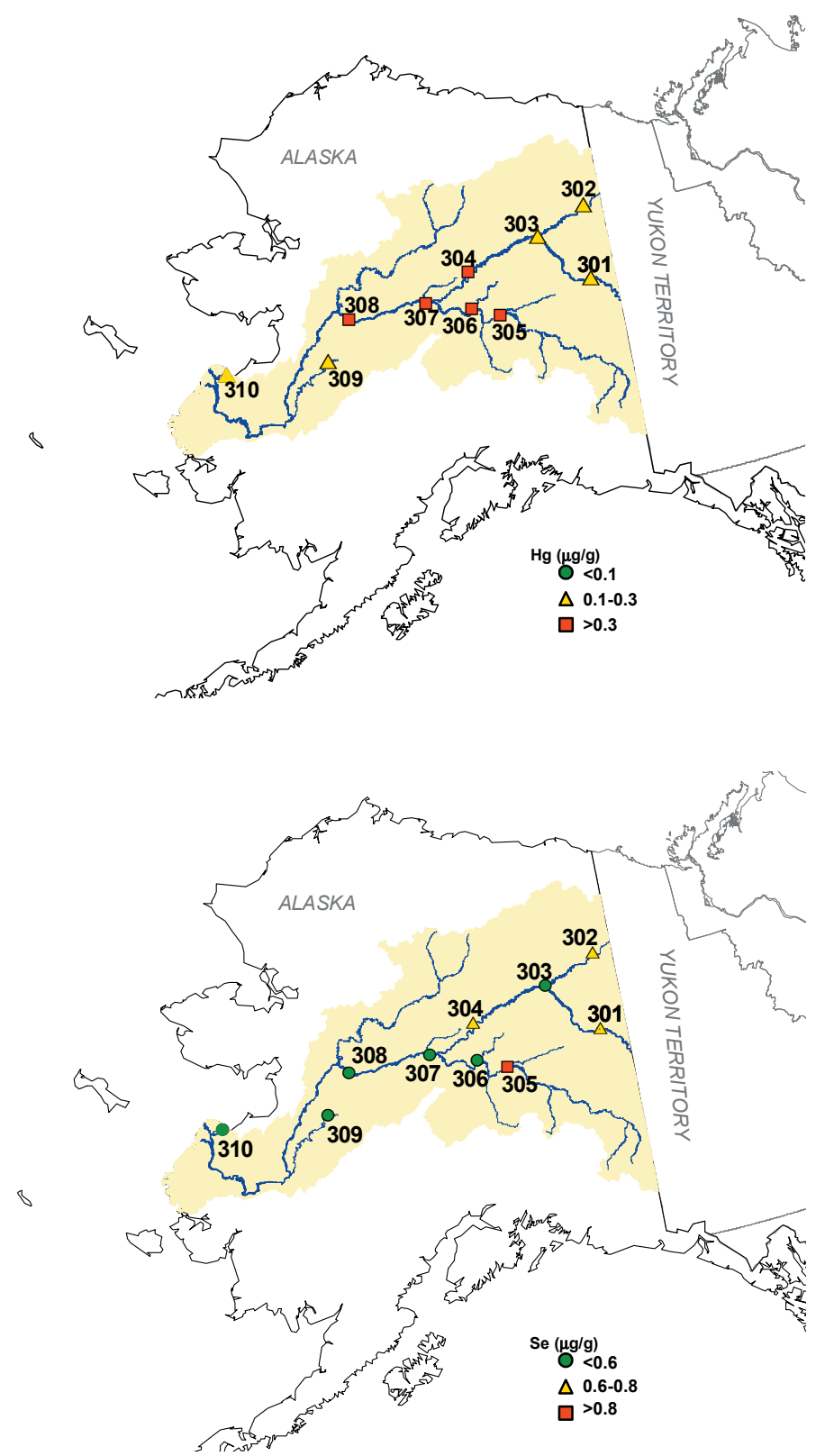

Figure 23. Maximum concentrations $(\mu \mathrm{g} / \mathrm{g} \mathrm{ww})$ of mercury $(\mathrm{Hg}$, upper panel) and selenium (Se, lower panel) in composite samples of whole fish. A concentration of $\mathrm{Hg}$ of $0.1 \mu \mathrm{g} / \mathrm{g} \mathrm{ww}$ in fish has been suggested as a guideline for the protection of piscivorous mammals (Yeardley and others, 1998), and concentrations of 0.3 $\mu \mathrm{g} / \mathrm{g}$ ww cause reproductive impairment in the common loon (Gavia immer) (Wiener and Spry, 1996; Wiener and others, 2002). Concentrations of Se should be $<0.6 \mu \mathrm{g} / \mathrm{g}$ ww to avoid toxicity to piscivorous wildlife and $<0.8 \mu \mathrm{g} / \mathrm{g} w w$ to avoid toxicity to fish (Lemly, 1996). See Table 1 for station descriptions. old criteria for any chemical contaminant at Station 303 (Table 22). External lesions and HAI in northern pike were the highest in the YRB. Most abnormalities were attributed to cuts or abrasions on the body surface which are typical in predatory fish like northern pike. The lesions could result from natural processes and are not indicative of exposure to environmental contaminants.

\section{Station 304 (Near the Bridge, AK)}

Station 304 was located on the Ray River near its confluence with the Yukon River near the Bridge. Male and female northern pike and female longnose sucker were collected from this site in early June 2002. Few contaminants and biomarkers exceeded threshold criteria or appeared anomalous at this site (Table 22). Concentrations of $\mathrm{Hg}$ in female $(0.46 \mu \mathrm{g} / \mathrm{g}$ ww) and male $(0.56 \mu \mathrm{g} / \mathrm{g} \mathrm{ww})$ northern pike exceeded criteria $(0.3 \mu \mathrm{g} / \mathrm{g} \mathrm{ww})$ shown to cause reproductive impairment in loons (Fig. 23; Barr, 1986). The concentration of Se in female longnose sucker $(0.60 \mu \mathrm{g} / \mathrm{g} \mathrm{ww})$ approached guidelines to protect fish and piscivorous wildlife (Fig. 23; Lemly, 1996). Fish health indicators were not anomalous in fish at Station 304 , but two reproductive biomarkers were highlighted. Two female northern pike had atresia $\geq 8 \%$ whereas other fish had $\leq 2 \%$. These differences in the atresia data could reflect natural variation in northern pike. Several female northern pike had E/KT ratios <1.0, and one male northern pike had an E/KT ratio of 7.66 (Fig. 25). The female northern pike with an E/KT ratio of 0.22 also had $9 \%$ atresia in the ovaries. These results may indicate isolated occurrences of reproductive stress for some fish at Station 304.

\section{Station 305 (Fairbanks, AK)}

Station 305 was located on the Tanana River downstream of Fairbanks. Female northern pike, male and female longnose sucker, and male and female burbot were collected in late May, late June, and mid-October 2002. Few contaminants and biomarkers exceeded threshold criteria or appeared anomalous at this site (Table 22). The concentration of $\mathrm{Hg}$ in male burbot was $0.30 \mu \mathrm{g} / \mathrm{g} \mathrm{ww}$, the concentration shown to cause reproductive impairment in loons (Fig. 23; Barr, 1986). Concentrations of Se in female longnose sucker $(0.61 \mu \mathrm{g} / \mathrm{g} \mathrm{ww})$, male burbot $(0.85 \mu \mathrm{g} / \mathrm{g} \mathrm{ww})$, and female burbot $(0.69 \mu \mathrm{g} / \mathrm{g} \mathrm{ww})$ exceeded guidelines to protect fish and piscivorous wildlife (Fig. 23; Lemly, 1996). The concentration of Se in male burbot was the maximum measured in the YRB. Two reproductive biomarkers were anomalous at Station 305: eight of $11(73 \%)$ male longnose sucker had concentrations of $\mathrm{vtg}>0.01 \mathrm{mg} / \mathrm{mL}$ (Fig. $24)$, and four (36\%) male longnose sucker had E/KT ratios $>1.0$ (Fig. 25). However, vtg was not detected $(>0.001 \mathrm{mg} /$ $\mathrm{mL}$ ) in the male longnose sucker with the greatest E/KT ratio (7.17). These results indicate that some fish were exposed to endocrine-modulating chemicals. 

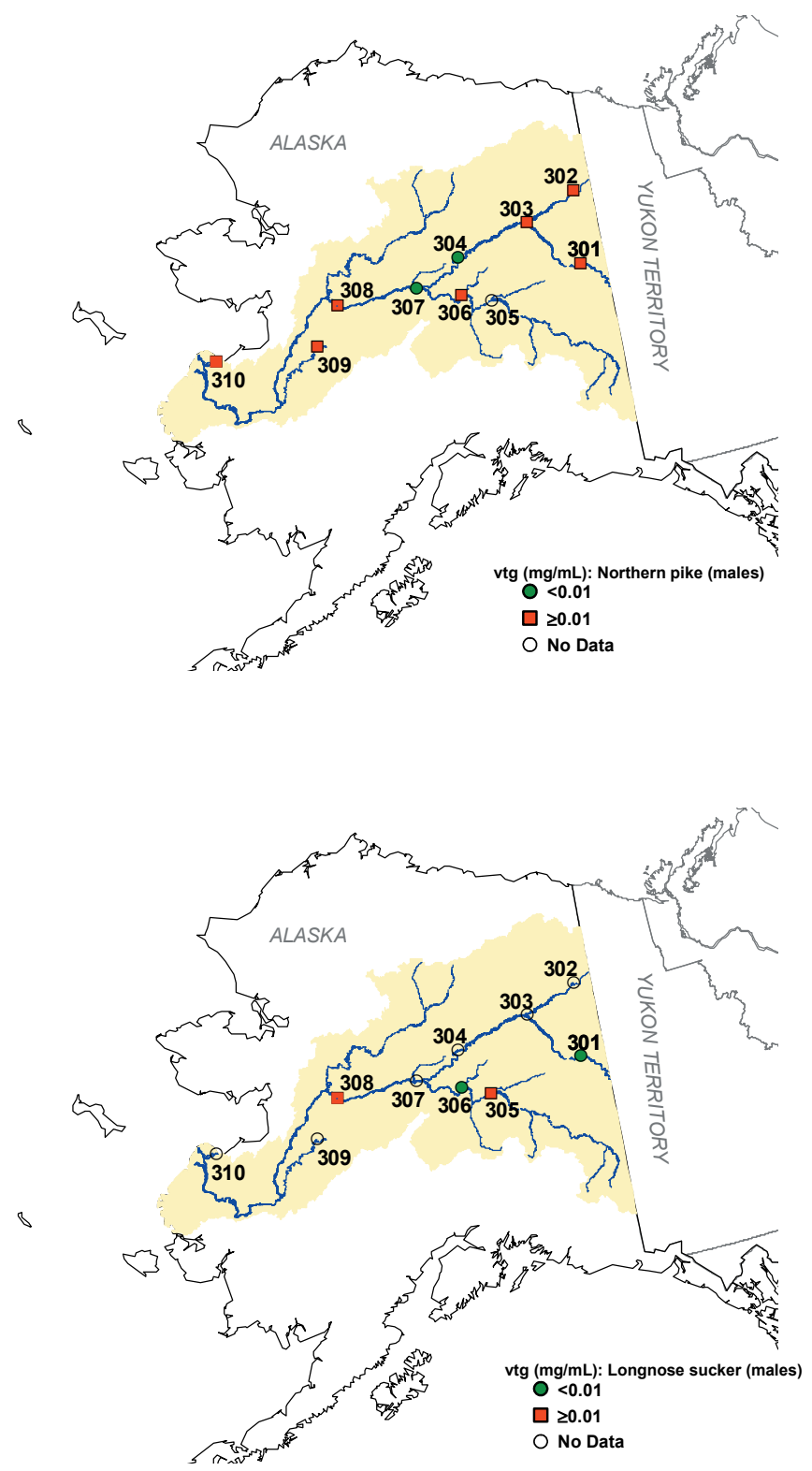

Figure 24. Plasma vitellogenin (vtg) in male northern pike (upper panel) and longnose sucker (lower panel). See Table 1 for station descriptions.

\section{Station 306 (Tolovana, AK)}

Station 306 was located on the Tanana River at its confluence with the Tolovana River. Male and female northern pike and longnose sucker were collected from this site in early June 2002. Mercury and biomarkers exceeded threshold criteria or appeared anomalous at this site (Table 22). The concentration of $\mathrm{Hg}$ in female northern pike $(0.69 \mu \mathrm{g} / \mathrm{g} \mathrm{ww})$ was the maximum measured in the YRB and exceeded criteria shown to cause reproductive impairment in loons (Fig. 23; Barr, 1986). Several fish health indicators were noted in fish at Station 306. SSI values were consistently greater in female northern pike and less in longnose sucker than other YRB stations. Several female northern pike had E/KT ratios $<1.0$, and several male northern pike and one male longnose sucker had an E/KT ratio $>1.0$ (Fig. 25). These results suggest isolated occurrences of biomarker responses to environmental contaminants.

\section{Station 307 (Tanana, AK)}

Station 307 was located on the Tanana River upstream of its confluence with the Yukon River near the village of Tanana. Male and female northern pike were collected from this site in early June 2002. Few contaminants and biomarkers exceeded threshold criteria or appeared anomalous at this site (Table 22). Concentrations of $\mathrm{Hg}$ in female $(0.37 \mu \mathrm{g} / \mathrm{g} \mathrm{ww})$ and male $(0.42 \mu \mathrm{g} / \mathrm{g} \mathrm{ww})$ northern pike exceeded criteria $(0.3 \mu \mathrm{g} / \mathrm{g} \mathrm{ww})$ shown to cause reproductive impairment in loons (Fig. 23; Barr, 1986). Multiple northern pike from Station 307 had HAI $>100$, mostly attributed to discolored liver and abrasions on the body surface. Northern pike were infected with a number of organisms including Ichthyophonus, hepatic biliary myxosporidians, and kidney tubular myxosporidians. There was no evidence to suggest biomarkers were altered at Station 307.

\section{Station 308 (Galena, AK)}

Station 308 was located on the Yukon River near the village of Galena. Male and female northern pike and longnose sucker were collected from this site in mid-June 2002. Several contaminants and biomarkers exceeded threshold criteria or appeared anomalous at this site (Table 22). Concentrations of $\mathrm{Hg}$ in female $(0.34 \mu \mathrm{g} / \mathrm{g} \mathrm{ww})$ and male $(0.33 \mu \mathrm{g} / \mathrm{g}$ ww) northern pike exceeded criteria $(0.3 \mu \mathrm{g} / \mathrm{g} w \mathrm{w})$ shown to cause reproductive impairment in loons (Fig. 23; Barr, 1986). Female northern pike from Station 308 had SSI values consistently greater than other YRB stations. Six of $12(50 \%)$ male northern pike and one male longnose sucker had concentrations of vtg $>0.01 \mathrm{mg} / \mathrm{mL}$ (Fig. 24). Two male northern pike had E/KT ratios $>1.0$ (Fig. 25). However, male northern pike with the greatest E/KT ratio (28.4) did not have a high concentration of $\mathrm{vtg}(0.018 \mathrm{mg} / \mathrm{mL})$. These results indicate isolated occurrences of reproductive stress for some fish at Station 308.

\section{Station 309 (Innoko NWR, AK)}

Station 309 was located on the Innoko River near the Innoko NWR Field Station. Male and female northern pike were collected in mid-July 2002. Concentrations of contaminants measured in northern pike did not exceed threshold criteria or appeared anomalous at Station 309 (Table 22). Vitellogenin in male northern pike and E/KT ratio in female northern pike were highlighted at this station. Concentrations of vtg were $>0.01 \mathrm{mg} / \mathrm{mL}$ in 6 of $11(55 \%)$ male northern pike from Station 309, indicating exposure to endocrine disrupting chemicals (Fig. 24). Several female northern pike had E/KT 

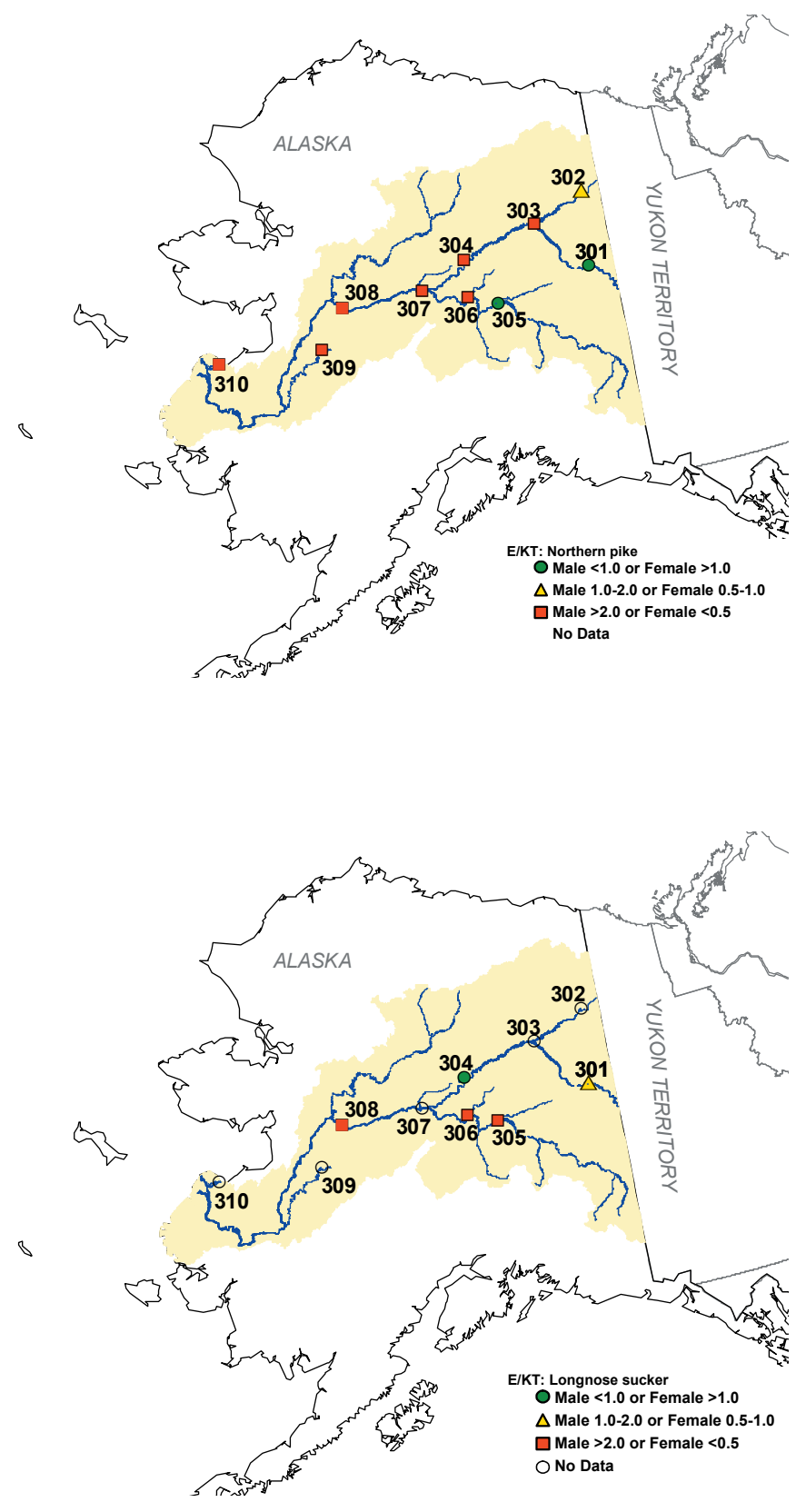

Figure 25. Ratio of estradiol to 11-ketotestosterone (E/KT) in northern pike (upper panel) and longnose sucker (lower panel). These ratios indicate female fish with low levels of estradiol and male fish with low levels of 11-ketotestosterone. See Table 1 for station descriptions.

ratios $<1.0$ (Fig. 25). These results suggest isolated occurrences of reproductive stress for some fish at Station 309.

\section{Station 310 (Kotlik, AK)}

Station 310 was located on the north mouth of the Yukon River $7 \mathrm{~km}$ upstream of the Bering Sea near the village of Kot- lik. Male and female northern pike and one male burbot were collected in early May 2002. Organochlorines and elemental contaminants were below protective criteria in all fish samples. $\mathrm{E} / \mathrm{KT}$ ratio was the only biomarker highlighted at this station (Table 22). Two female northern pike had E/KT ratios $<1.0$ (Fig. 25), although reproductive stress does not appear to be widespread at Station 310.

\section{Correlations Between Contaminant Concentrations and Biological Endpoints}

Spearman Rank correlations were examined to determine if chemical concentrations were related to biomarker responses in the YRB (Table 23). However, only $\mathrm{Hg}$ and $\mathrm{Se}$ were examined, because they were the only contaminants consistently measured $>$ LOD. Significant correlations $(P<0.05)$ were determined for each gender and species. Few biomarker responses were found to be correlated with $\mathrm{Hg}$ or $\mathrm{Se}$ and present in more than one species, gender, or both (Table 23). Mercury was correlated with age, length, and weight in female northern pike. This correlation was expected due to the bioaccumulative properties of $\mathrm{Hg}$. MA-size in both male northern pike and longnose sucker increased with concentrations of $\mathrm{Hg}$. Mercury in male northern pike was also positively correlated with E2 and E/KT. The small sample size and range of concentrations limit the interpretation of the YRB data.

\section{Summary and Conclusions}

Overall, few chemical contaminants or biological endpoints indicated poor fish health in northern pike, longnose sucker, or burbot collected from the YRB in 2002. Organochlorine contaminants in fish samples were $<\mathrm{LOD}$ at most stations, which is consistent with results from previous YRB studies (Schmitt and others, 1999b; Snyder-Conn, 1992). Fish samples with concentrations of $\mathrm{Hg}$ exceeding $0.3 \mu \mathrm{g} / \mathrm{g}$ ww and Se exceeding $0.6 \mu \mathrm{g} / \mathrm{g}$ ww were measured at several stations; these concentrations are potentially harmful to piscivorous wildlife (Lemly, 1996; Wiener and Spry, 1996; Wiener and others, 2002). However, no other chemical contaminants exceeded wildlife criteria in YRB fish. Concentrations of $\mathrm{Hg}$ in male and female northern pike in the mid-YRB from Stations 304 (The Bridge), 305 (Fairbanks), 306 (Tolovana), 307 (Tanana), and 308 (Galena) exceeded protective criteria. Concentrations of Se exceeded criteria in fish samples from the upper YRB near the Canadian border at Stations 301 (near the Charley-Kandik confluence) and 302 (Fish Hook Bend), the mid-YRB at Station 304 (The Bridge), and near Fairbanks at Station 305. Concentrations of $\mathrm{Hg}$ and Se exceeding wildlife criteria were measured primarily in male northern pike and female longnose sucker. It is difficult to determine the source 
Table 23. Significant Spearman rank correlations $(P<0.05)$ between biomarkers and contaminants. See text for biomarker definitions. Black text, positive correlations; bold italicized text, negative correlations. Genders were not combined in this analysis because many biomarker differed between males and females.

\begin{tabular}{lll}
\hline Biomarker & $\mathrm{Hg}$ & $\mathrm{Se}$ \\
\hline Age & female pike & \\
Total Length & female pike & \\
Weight & female pike & \\
MA-size & male sucker, male pike & female sucker \\
MA-\# & & male sucker \\
E2 & female sucker, male pike & \\
E/KT & male sucker, male pike & \\
EROD & & male pike \\
\hline
\end{tabular}

or origin of $\mathrm{Hg}$ and $\mathrm{Se}$ in northern pike because it is a migratory species, and longnose sucker is believed to swim randomly in streams (Mueller and others, 1996). However, most Se is believed to enter the Yukon River system through the natural weathering of rocks. Atmospheric deposition is one of the main contributors of $\mathrm{Hg}$ in the YRB and other Arctic areas (NCP, 2003).

Dioxin-like activity as measured by TCDD-EQs and EROD activity were unremarkable in the YRB. Dioxin-like activity was $<$ LOD in YRB fish samples, which is consistent with a previous dioxin study in the basin (Snyder-Conn, 1992). EROD activity was generally low in fish from all YRB stations. Station 301 (near the Charley-Kandik confluence) had the greatest station mean for male northern pike (17.51 $\mathrm{pmol} / \mathrm{min} / \mathrm{mg})$, female northern pike $(8.57 \mathrm{pmol} / \mathrm{min} / \mathrm{mg})$, male longnose sucker (10.03 pmol/min/mg), and female longnose sucker $(8.78 \mathrm{pmol} / \mathrm{min} / \mathrm{mg})$. However, the EROD activities in these fish were less than previous EROD data for these species in past BEST LRMN investigations (Schmitt and others, 2002a; Hinck and others, 2004). Factors other than contaminant exposure such as water temperature and nutrition may be responsible for the slightly higher EROD activities at Station 301.

Our study is the first to examine an extensive suite of biomarkers in relation to environmental contaminants in fish from the YRB. Fish health indicators and reproductive biomarkers did not indicate widespread responses to contaminants, but individual fish throughout the basin expressed isolated responses. Isolated occurrences of enlarged spleens (Stations 301, 306, and 308) and prevalence of external lesions (Station 303 ) in northern pike are likely attributed to factors such as age, size, growth rate, and gonadal development (Krykhitin, 1976; Ruklov, 1979), although these conditions have also been reported as consequences of immune suppression caused by chemical exposure (Anderson and others, 1989; Hutchinson and Manning, 1996). The latter explanation is unlikely because MA density, size, and percent tissue occupied were similar among stations for each species, although northern pike from Station 306 (Tolovana) did have greater MA densities compared to the other YRB stations.

Concentrations of $\mathrm{vtg}>0.01 \mathrm{mg} / \mathrm{mL}$ are not typical in male fish and may indicate an estrogenic response to environmental conditions. Concentrations of vtg were $>0.01 \mathrm{mg} / \mathrm{mL}$ in multiple male fish from Stations 301 (near the CharleyKandik confluence), 305 (Fairbanks), 308 (Galena), and 309 (Innoko). Steroid hormone concentrations (E2 in female fish and $\mathrm{KT}$ in male fish) were low in northern pike, longnose sucker, or both from Stations 303 (Fort Yukon), 304 (The Bridge), 305 (Fairbanks), 306 (Tolovana), 308 (Galena), 309 (Innoko), and 310 (Kotlik). However, many factors such as season, gender, and geographical location can affect circulating steroid hormone levels in fish (see review in Schmitt and Dethloff, 2000).

Overall, we determined there was no evidence to indicate that fish from the YRB had been exposed to high concentrations of environmental contaminants. Similar conclusions have been reported other U.S. river basins (Hinck and others, 2004; Schmitt, 2002a; Schmitt and others, 2004). The YRB is unique in that it is largely undisturbed by population and industrial centers and is considered pristine compared to other U.S. river basins. Nevertheless, these current attributes may change in the future, resulting in the degradation of water quality and aquatic habitat within the YRB. Therefore, results from our study may provide reference or baseline data on environmental contaminants and their effects in fish for future investigations in the YRB.

\section{References}

Aagaard, K., and Carmack, E.C., 1989, The role of sea ice and other fresh water in the Arctic circulation: Journal of Geophysical Research, v. 94, p. 14485-14498.

Aaseth J. and Norseth T., 1986, Copper. in Friberg L., Nordberg G.F., and Vouk V., eds., Handbook of the toxicology of metals, $2^{\text {nd }}$ edition, volume II: specific metals: Elsevier Science, Amsterdam.

Ackerman, G.E., Brombacher, E., and Fent, K., 2002, Development of a fish reporter gene system for the assessment of estrogenic compounds and sewage treatment plant effluents: Environmental Toxicology and Chemistry, v. 21, no. 9, p. 1864-1875.

Adams, S.M., Brown, A.M., and Goede, R.W., 1993, A quantitative health assessment index for rapid evaluation of fish condition in the field: Transactions of the American Fisheries Society, v. 122, p. 63-73. 
Adams, S.M., Crumby, W.D., Greeley, M.S., Jr., Ryon, M.G., and Schilling, E.M., 1992, Relationships between physiological and fish population responses in a contaminated stream: Environmental Toxicology and Chemistry, v. 11, no. 11, p. 1549-1557.

Adams, S.M., McLean, R.B., and Parrotta, J.A., 1982, Energy partitioning in largemouth bass under conditions of seasonally fluctuating prey availability: Transactions of the American Fisheries Society, v. 111, no. 5, p. 549-558.

Adams, S.M., and McLean, R.B., 1985, Estimation of largemouth bass, Micropterus salmoides lacepede, growth using the liver somatic index and physiological variables: Journal of Fish Biology, v. 26, p. 111-126.

Adams, S.M., Crumby, W.D., Greeley, M.S., Jr., Ryon, M.G., and Schilling, E.M., 1992, Relationships between physiological and fish population responses in a contaminated stream: Environmental Toxicology and Chemistry, v. 11, no. 11, p. 1549-1557.

Addison, R.F., Hansen, P.D, Pluta, H.J., and Willis, D.E., 1991, Effects of Ugilec-141 ${ }^{\circledR}$, a PCB substitute based on tetrachlorobenzyltoluenes, on hepatic nono-oxygenase induction in estuarine fish: Marine Environmental Research, v. 31 , p. 137-144.

Agius, C., 1979, The role of melano-machrophage centres in iron storage in normal and diseased fish: Journal of Fish Diseases, v. 2, p. 337-343.

Agius, C., 1980, Phylogenetic development of melano-macrophage centres in fish: Journal of Zoology, v. 191, p. 11-31.

Agius, C., and Roberts, R.J., 1981, Effects of starvation on the melano-macrophage centres of fish: Journal of Fish Biology, v. 19, p. 161-169.

Air Resource Specialists, Inc., and Cahill, C. F., , 2003, Final Report on the results from the Poker Flat, Denali National Park and Preserve, and Trapper Creek CASTNET Protocol Sites July 1998 through June 2001, Fort Collins, Colorado. $77 \mathrm{p}$.

Alaska Department of Community and Economic Development (ADCED), 2004a, Community Database Online, Research and Analysis Section: <http://www.dced.state. ak.us/dca/commdb/CF_COMDB.htm> (accessed June 2004).

Alaska Department of Community and Economic Development (ADCED), 2004b, Alaska Economic Information Systems: <http://www.commerce.state.ak.us/dca/AEIS/ AEIS_Home.htm (accessed June 2004).
Alaska Department of Environmental Conservation (ADEC), 2003a, Alaska's Final Draft 2002/2003 Integrated Water Quality Monitoring and Assessment Report August 2003. AK Dept. of Environmental Conservation, Division of Air and Water Quality. 98 p.

Alaska Department of Environmental Conservation (ADEC), 2003b, Fish Monitoring Project: <http://www.state.ak.us/ dec/eh/vet/fish.htm> (accessed January 2004).

Alaska Department of Environmental Conservation (ADEC), 2003c, Statewide Summary of Oil and Hazardous Substance Spill Data (Fiscal Years 1996-2002), Provisional Report: Alaska Department of Environmental Conservation, Division of Spill, Prevention, and Response, 148 p.

Alaska Department of Environmental Conservation (ADEC), 2004a, Long-term monitoring and residential well results: Six mile Richardson highway: Contaminated Sites Program, 2003 Fact Sheet, January 2004, 4 p.

Alaska Department of Environmental Conservation (ADEC), 2004b, Dioxins and the Haines-Fairbanks Pipeline, fact sheet, Contaminated Sites Program, Juneau, AK, January 2004.

Alaska Department of Health and Social Services (ADHSS), 2001, Mercury and National Fish Advisories, Recommendations for fish consumption in Alaska: State of Alaska Epidemiology, Bulletin No. 6, June 15, 2001, 2 p.

Alaska Department of Labor, 1999, Research \& analysis, demographics unit, population estimates: <http://almis. labor.state.ak.us/> (accessed January 1999).

Allen, Y., Scott, A.P., Matthiessen, P., Haworth, S., Thain, J.E., and Feist, S., 1999, Survey of estrogenic activity in United Kingdom estuarine and coastal waters and its effects on gonadal development of the flounder Platichthys flesus: Environmental Toxicology and Chemistry v. 1, p. 17911800.

Anderson, D.W., Jehl, J. R., Jr., Risebrough, R. W., Woods, L. A., Jr., DeWeese, L. R., and Edgecomb, W.G., 1975, Brown pelicans: improved reproduction off the southern California coast: Science, v. 190, p. 806-808.

Anderson, D.P., Dixon, O.W., Bodammer, J.E., and Lizzio, E.F., 1989, Suppression of antibody-producing cells in rainbow trout spleen sections exposed to copper in vitro: Journal of Aquatic Animal Health, v. 1, p. 57-61.

Ankley, G.T., Tillitt, D.E., Gooch, J.W., and Giesy, J.P., 1989, Hepatic enzyme systems as biochemical indicators of the effects of contaminants on reproduction of Chinook salmon (Oncorhynchus tschawytscha): Comparative Biochemistry and Physiology Part C, v. 94, p. 235-242. 
Arctic Monitoring and Assessment Programme (AMAP), 1998, AMAP Assessment Report: Arctic pollution issues: Oslo, Norway. 859 p.

Ballew, C., Ross, A., Wells, R., Hiratsuka, V., Hamrick, K., and Nobmann, E., 2004, Final Report on the Alaska traditional diet: Alaska Native Epidemiology Center, Alaska Native Health Board, Anchorage, AK. March 2004. 171 p.

Barr, J.F., 1986, Population dynamics of the common loon (Gavia immer) associated with mercury-contaminated waters in northwestern Ontario: Occasional Paper 56, Canadian Wildlife Service, Ottawa, Ontario.

Barry T.P., Santos T., Furukawa K., Aida K., and Hanyu, I., 1990, Steroid profiles during spawning in male common carp: General Comparative Endocrinology, v.80, p. 223.

Beamish, F.W.H., Jebbink, J.A., Rossiter, A., and Noakes, D.L.G., 1996, Growth strategy of juvenile lake sturgeon (Acipenser fulvescens) in a northern river: Canadian Journal of Fisheries and Aquatic Sciences, v. 53, p. 481-489.

Beyer, W.N., Heinz, G.H., and Redmon-Norwood, A.W., eds., 1996, Environmental contaminants in wildlife: interpreting tissue concentrations: Boca Raton, FL, Lewis Publishers, $494 \mathrm{p}$.

Bidleman, T.F., Wall, M.D., Muir, D.C.G., and Stern, G.A., 1993, Selective accumulations of polychlorocamphenes in aquatic biota from the Canadian arctic: Environmental Toxicology and Chemistry, v. 12., no. 4, p. 701-710.

Bidwell, C.A., and Carlson, P.M., 1995, Characterization of vitellogenin from white sturgeon, Acipenser transmontanus: Journal of Molecular Evolution, v. 41, no. 1, p. 104-112.

Blazer, V.S., Wolke, R.E., Brown, J., and Powell, C.A., 1987, Piscine macrophage aggregate parameters as health monitors: effect of age, sex, relative weight, season and site quality in largemouth bass (Micropterus salmoides): Aquatic Toxicology, v. 10, no. 4, p. 199-215.

Blazer, V.S., Facey, D.E., Fournie, J.W., Courtney, L.A., and Summers, J.K., 1994, Macrophage aggregates as indicators of environmental stress, in Stolen, J.S., and Fletcher, T.C., eds., Modulators of fish immune responses: volume one, models for environmental toxicology, biomarkers, immunostimulators: Fair Haven, NJ, SOS Publications, p. 169-185.

Blazer, V.S., Fournie, J.W., and Weeks-Perkins, B.A., 1997, Macrophage aggregates: biomarker for immune function in fishes?, in Dwyer, F.J., Doane, T.R., and Hinman, M.L. eds., Environmental toxicology and risk assessment: modeling and risk assessment, v. 6: American Society for Testing and Materials, ASTM Special Technical Publication 1317.
Blazer, V.S., Dethloff, G.M, and Wright, B., 2002, Fish health indicators, in Biomonitoring of Environmental Status and Trends (BEST) Program: environmental contaminants and their effects on fish in the Mississippi River basin: U.S. Geological Survey, Biological Resources Division, Biological Science Report 2002-0004, p. 89-134.

Blus, L.J., 1996, DDT, DDD, and DDE in birds, in Beyer, W.N., Heinz, G.H., Redmon-Norwood, A.W., eds., Environmental contaminants in wildlife: interpreting tissue concentrations: Boca Raton, FL, Lewis Publishers, p. 49-71.

Bostock, H.S., 1970, Physiographic regions of Canada: Geological Survey of Canada, Map 1254A, scale 1:5,000,000.

Bowman, C.J., Kroll, K.J., Gross, T.G., and Denslow, N.D., 2002, Estradio-induced gene expression in largemouth bass (Micropterus salmoides): Molecular and Cellular Endocrinology, v. 196, p. 67-77.

Brabets, T.P., Wang, B., and Meade, R. H., 2000, Environmental and hydrologic overview of the Yukon River Basin, Alaska and Canada: U.S. Geological Survey WaterResources Investigations Report 99-4204, 106 p.

Braune, B., Muir, D., DeMarch, B., Gamberg, M, Poole, K., Currie, R., Dodd, M., Duschenko, W., Eamer, J., Elkin, B., Evans, M., Grundy, S., Herbert, C., Johnstone, R., Kidd, K., Koeing, B., Lockhart, L., Marshall, H., Reimer, K., Sanderson, L., and Shutt, L., 1999, Spatial and temporal trends in contaminants in Canadian Arctic freshwater and terrestrial ecosystems: a review: Science of the Total Environment, v. 230, p. 145-207.

Bromage, N.R., Whitehead, C., and Breton, B., 1982, Relationships between serum levels of gonadotropin, oestradiol $17-\beta$ and vitellogenin in the control of ovarian development in the rainbow trout: General and Comparative Endocrinology, v. 47, p. 366-376.

Brown, C.L., and George, C.T., 1985, Age-dependent accumulation of macrophage aggregates in the yellow perch Perca flavescens (Mitchell): Journal of Fish Diseases, v. 8, p. 136-138.

Brumbaugh, W.G., Krabbenhoft, D.P., Helsel, D.R., Wiener, J.G., and Echols, K.R., 2001, A national pilot study of mercury contamination of aquatic ecosystems along multiple gradients: bioaccumulation in fish. U.S. Geological Survey, Columbia, MO, Biological Science Report USGS/BRD/ BSR-2001-0009, 25 p.

Buhl, K.J., and Hamilton, S.J., 1990, Comparative toxicity of inorganic contaminants released by placer mining to early life stages of salmonids: Ecotoxicology and Environmental Safety, v. 20, p. 325-342. 
Buhler, D.R., Rasmusson, M.E., and Shanks, W.E., 1969, Chronic oral DDT toxicity in juvenile coho and Chinook salmon: Toxicology and Applied Pharmacology, v. 14, p. 535-555.

Bunton, T.E., Baksi, S.M., Gelrge, S.M., and Frasier, J.M., 1987, Abnormal hepatic copper storage in a teleost fish (Morone americana): Veterinary Pathology, v. 24, p. 515524.

Burdick, G.E., Harris, E.J., Dean, H.J., Walker, T.M., Skea, J., and Colby, D., 1964, Accumulation of DDT in lake trout and the effect on reproduction: Transactions of the American Fisheries Society, v. 93, p. 127-136.

Campbell, C.M., and Idler, D.R., 1976, Steroids in the plasma of the winter flounder (Pseudopleuronectes americanus Walbaum): a seasonal study and investigation of steroid involvement in oocyte maturation: General Comparative Endocrinology, v. 29, p. 14-20.

Carlander, K.D., 1969, Handbook of freshwater fishery biology, volume 1: Ames, IA, Iowa State University Press, 431 p.

Causey, J., 1998, Mineral Availability System/Mineral Industry Locator System (MAS/MILS database): U.S. Geological Survey, Denver, CO.

Chang, C.F., and Chen, M.R., 1990, Fluctuation in sex steroids and sex-binding protein during the development and annual cycle of the male common carp (Cyprinus carpio): Comparative Biochemistry and Physiology Part A, v. 97, no. 4, p. $565-568$.

Chang, S., Zdanowicz, V.S., and Murchelano, R.A., 1998, Associations between liver lesions in winter flounder (Pleuronectes americanus) and sediment chemical contaminants from northeast United States estuaries: ICES Journal of Marine Science, v. 55, p. 954-969.

Childress, C.J.O., Foreman, W.T., Conner, B.F., and Maloney, T.J., 1999, New reporting procedures based on long-term method detection levels and some considerations for interpretations of water-quality data provided by the U.S. Geological Survey National Water Quality Laboratory: USGS Open File Report 99-193, 19 p.

Chilton, D.E. and Beamish, R.J., 1982, Age determination methods for fishes studied by the groundfish program at the Pacific Biological Station: Department of Fisheries and Oceans, Canadian Special Publication of Fisheries and Aquatic Sciences 60, Ottawa, Ontario.

Coulliard, C.M., and Hodson, P.V., 1996, Pigmented macrophage aggregates: a toxic response in fish exposed to bleached-kraft mill effluent?: Environmental Toxicology and Chemistry, v. 15, p. 1844-1854.
Coyle, J.J., Buckler, D.R., Ingersoll, C.G., Fairchild, J.F., and May, T.W., 1993, Effects of dietary selenium on the reproductive success of bluegills (Lepomis macrochirus): Environmental Toxicology and Chemistry, v. 12, p. 551-565.

Cross, J.N., and Hose, J.E., 1988, Evidence for impaired reproduction in white croaker (Genyonemus lineatus) from contaminated areas off southern California: Marine Environmental Research, v. 24, p. 185-188.

Cross, J.N., and Hose, J.E., 1989, Reproductive impairment in two species of fish from contaminated areas off southern California, in Oceans '89: The Global Ocean, Seattle, WA, 1989, New York, NY, Institute of Electrical and Electronics Engineers.

Cuerrier, J.P., Keith, J.A., and Stone, E., 1967, Problems with DDT in fish culture operations: Naturaliste Canada, v. 94, p. 315-320.

Daniels, W.H., and Robinson, E.H., 1986, Protein and energy requirements of juvenile red drum (Sciaenops ocellatus): Aquaculture, v. 53, p. 243-252.

Dansereau, M., Lariviere, N., Tremblay, D., and Belanger, D., 1999, Reproductive performance of two generations of female semidomesticated mink fed diets containing organic mercury contaminated freshwater fish: Archives of Environmental Contaminants and Toxicology, v., 36, p. 221-226.

Delahunty, G., and de Vlaming, V.L., 1980, Seasonal relationships of ovary weight, liver weight, and fat stores with body weight in the goldfish, Carassius auratus (L): Journal of Fish Biology, v. 16, p. 5-13.

Denslow, N.D., Chow, M.C., Kroll, K.J. and Green, L., 1999, Vitellogenin as a biomarker of exposure for estrogen or estrogen mimics: Ecotoxicology, v. 8, p. 385-398.

Denton, J.E., and Yousef, M.K., 1976, Body composition and organ weights of rainbow trout, Salmo gairdneri: Journal of Fish Biology, v. 8, no. 6, p. 489-499.

Deschu, N., 1985, Arsenic in sediments, water, and benthic fish in placer-mined and unmined streams, Denali National Park and Preserve, Alaska: Master's Degree Thesis, Department of Civil Engineering, University of Washington, 90 p.

de Vlaming, V.L., Grossman, G., and Chapman, F., 1981, On the use of gonadosomatic index: Comparative Biochemistry and Physiology Part A, v. 73, p. 31-39.

Dethloff, G.M., and Schmitt, C.J., 2000, Condition factor and organo-somatic indices, in Schmitt, C.J. and Dethloff, G.M. eds., Biomonitoring of Environmental Status and Trends (BEST) Program: selected methods for monitoring chemical contaminants in aquatic ecosystems: U.S. Geological Survey, Biological Resources Division, Information and Technology Report 2000-0005, p. 13-17. 
Dietz, R., Nielson, C.O., Hansen, M.M., and Hansen, C.T., 1990, Organic mercury in Greenland birds and mammals: Science for Total Environment, v. 95, p. 41-51.

Down, N.E., Peter, R.E., and Leatherland, J.F., 1990, Seasonal changes in serum gonadotropin, testosterone, 11-ketotestosterone, and estradiol-17 $\beta$ levels and their relation to tumor burden in gonadal tumor-bearing carp $\mathrm{x}$ goldfish hybrids in the Great Lakes: General and Comparative Endocrinology, v. 77 , p. 192-201.

Doyon, J.F., Downing, J.A., and Manin, E., 1988, Variation in the condition of northern pike, Esox lucius: Canadian Journal of Fisheries and Aquatic Sciences, v. 45, p. 479-483.

Drevnick, P.E., and Sandheinrich, M.B., 2003, Effects of dietary methylmercury on reproductive endocrinology of fathead minnows: Environmental Science \& Technology, v. 37, p. 4390-4396.

Duffy, L.K., Rodgers, T., and Patton, M., 1998, Regional health assessment relating to mercury content of fish caught in the Yukon-Kuskokwim delta rivers system: Alaska Medicine, 1998 Oct-Dec; v. 40, no. 4, p. 75-7, 89, Erratum in: Alaska Medicine, 1999, Jan-Mar, v. 41, p. 1-15.

Duffy, L.K., Scofield, E., Rodgers, T., Patton, M., and Bowyer, R.T., 1999, Comparative baseline levels of mercury, Hsp 70 and Hsp 60 in subsistence fish from the Yukon-Kuskokwim delta region of Alaska: Comparative Biochemistry and Physiology Part C, v. 124, p. 181-186.

Egeland, G.M., Feyk, L.A., and Middaugh, J.P., 1998, The use of traditional foods in a healthy diet in Alaska: risks in perspective: Alaska Division of Public Health, Section of Epidemiology. 144 p.

Eisler, R., 1985, Cadmium hazards to fish, wildlife, and invertebrates: a synoptic review: U.S. Fish and Wildlife Service, Biological Report 85(1.2), 46 p.

Eisler, R., and Jacknow, J., 1985, Toxaphene hazards to fish, wildlife, and invertebrates: a synoptic review: U.S. Fish and Wildlife Service, Biological Report 85 (1.4), 26 p.

Eisler, R., 1986, Chromium hazards to fish, wildlife, and invertebrates: a synoptic review. U.S. Fish and Wildlife Service, Biological Report 85(1.6), 60 p.

Eisler, R., 1987, Mercury hazards to fish, wildlife, and invertebrates: a synoptic review. U.S. Fish and Wildlife Service, Biological Report 85(1.10), 90 p.

Eisler, R., 1990, Chlordane hazards to fish, wildlife, and invertebrates: a synoptic review: U.S. Fish and Wildlife Service, Biological Report 85(1.21), 49 p.

Eisler, R., 1993, Zinc hazards to fish, wildlife, and invertebrates: a synoptic review. U.S. Fish and Wildlife Service, Biological Report 10, 106 p.
Eisler, R., 1997, Copper hazards to fish, wildlife, and invertebrates: a synoptic review. U.S. Geological Survey, Biological Resources Division, Biological Science Report USGS/ BRD/BSR—1997-0002, 98 p.

Ellis, A.E., Munro, A.L.S., and Roberts, R.J., 1976, Defense mechanisms in fish 1: A study of the phagocytic system and the fate of intraperitoneally injected particulate material in the plaice (Pleuronectes platessa L.): Journal of Fish Biology, v. 8, p. 67-78.

Environment Canada, 1999, Yukon SOE [state of the environment] highlights —Land and people: <www.taiga.net/ yukonsoe/hilp.html> (accessed January 2004).

Fabacher, D.L., and Baumann, P.C., 1985, Enlarged livers and hepatic microsomal mixed-function oxidase components in tumor-bearing brown bullheads from a chemically contaminated river: Environmental Toxicology and Chemistry, v. 4, no. 5, p. 703-710.

Ferguson, H.W., 1976, The relationship between ellipsoids and melano-macrophage centres in the spleen of turbot (Scophthalmus maximus): Journal of Comparative Pathology, v. 86, p. 377-380.

Fine, M., Zilberg, D., Cohen, Z., Degani, G., Moav, B., and Gertler, A., 1996, The effect of dietary protein level, water temperature, and growth hormone administration on growth and metabolism in the common carp (Cyprinus carpio): Comparative Biochemistry and Physiology Part A, v. 114, p. 35-42.

Fisher, J.P., Fitzsimons, J.D., Combs, G.F., Jr., and Spitsbergen, J.M., 1996, Naturally occurring thiamine deficiency causing reproductive failure in Finger Lakes Atlantic salmon and Great Lakes lake trout: Transactions of the American Fisheries Society, v. 125, no. 2, p. 167-178.

Fjeld, E., Haugen, T.O., and Vollestad, L.A., 1998, Permanent impairment in the feeding behavior of grayling (Thymallus thymallus) exposed to methylmercury during embryogenesis: Science for the Total Environment, v. 213, p. 247-254.

Folmar, L.C., Denslow, N.D., Rao, V., Chow, M., Crain, D.A., Enblom, J., Marcino, J., and Guillette, L.J., Jr., 1996, Vitellogenin induction and reduced serum testosterone concentrations in feral male carp (Cyprinus carpio) captured near a major metropolitan sewage treatment plant: Environmental Health Perspectives, v. 104, no. 10, p. 1096-1101.

Folmar, L.C., Hemmer, M., Hemmer, R., Bowman, C., Kroll, K., and Denslow, N.D., 2000, Comparative estrogenicity of estradiol, enthynyl estradiol and diethylstilbestrol in an in vivo, male sheepshead minnow (Cyprinodon variagatus), vitellogenin bioassay: Aquatic Toxicology, v. 49, p. 77-88. 
Folmar, L.C., Gardner, G.R., Schreibman, M.P., MagliuloCepriano, L., Mills, L.J., Zaroogian, G., Gutjahr-Gobell, R., Haebler, R., Horowitz, D.B., and Denslow, N.D., 2001, Vitellogenin-induced pathology in male summer flounder (Paralichthys dentatus): Aquatic Toxicology, v. 51, no. 4, p. 431-441.

Förlin, L., and Haux, C., 1990, Sex differences in hepatic cytochrome P-450 monooxygenase activities in rainbow trout during an annual reproductive cycle: Journal of Endocrinology, v. 124, p. 207-213.

Foster, A.R., Houlihan, D.F., and Hall, S.J., 1993, Effects of nutritional regime on correlates of growth rate in juvenile Atlantic cod (Gadhus morhua): comparisons of morphological and biochemical measurements: Canadian Journal of Fisheries and Aquatic Sciences, v. 50, p. 502-512.

Fournie, J.W., Summers, J.K., and Weisberg, S.B., 1996, Prevalence of gross pathological abnormalities in estuarine fishes: Transactions of the American Fisheries Society, v. 125 , no. 4 , p. 581-590.

Fournie, J.W., Summers, J.K., Courtney, L.A., Engle, V.D., and Blazer, V.S., 2001, Utility of splenic macrophage aggregates as an indicator of fish exposure to degraded environments: Journal of Aquatic Animal Health, v. 13, no. 2, p. 105-116.

Gallant, A.L., Binnian, E.F., Omernik, J.M., and Shasby, M.B., 1995, Ecoregions of Alaska: U.S. Geological Survey Professional Paper 1567, 73 p.

Giesy, J.P., Bowerman, W.W., Mora, M.A., Verbrugee, D.A., Othoudt, R.A., Newsted, J.L., Summer, C.L., Aulerich, R.J., Bursian, S.J., Ludwig, J.P., Dawson, G.A., Kubiak, T.J., Best, D.A., and Tillitt, D.E., 1995, Contaminants in fishes from Great Lakes-influenced sections and above dams of three Michigan rivers: III Implications for health of bald eagles: Archives of Environmental Contamination and Toxicology, v. 29, p. 309-321.

Gilderhus, P.A., 1966, Some effects of sublethal concentrations of sodium arsenate on bluegills and the aquatic environment: Transactions of the American Fisheries Society, v. 95, p. 289-296.

Gillespie, R.B., and Baumann, P.C., 1986, Effects of high tissue concentrations of selenium on reproduction by bluegills: Transactions of the American Fisheries Society, v. 115, p. 208-213.

Gimeno, S., Komen, H., Venderbosch, P., and Bowmer, T., 1997, Disruption of sexual differentiation in genetic male common carp (Cyprinus carpio) exposed to an alkylphenol during different life stages: Environmental Science \& Technology, v. 31, p. 2884-2890.
Gimeno, S., Komen, H., Gerritsen, A., and Bowmer, T., 1998, Feminisation of young males of the common carp, Cyprinus carpio, exposed to 4-tert-pentylphenol during sexual differentiation: Aquatic Toxicology, v. 43, p. 77-92.

Gingerich, W.H., 1982, Hepatic toxicology of fishes, in Weber, L.J., ed., Aquatic toxicology: New York, NY, Raven Press, p. 55-105.

Goede, R.W., 1988, Fish health/condition assessment procedures. Part 2 - a color atlas of necropsy classification categories: Utah Division of Wildlife Resources, Fisheries Experiment Station.

Goede, R.W., 1996, Fish health/condition assessment procedures. Part 1 - procedure manual: Utah Division of Wildlife Resources, Fisheries Experiment Station, 31 p.

Goede, R.W., and Barton, B.A., 1990, Organismic indices and an autopsy-based assessment as indicators of health and condition of fish, in Adams, S.M., ed., Biological indicators of stress in fish: American Fisheries Society symposium 8: Bethesda, MD, American Fisheries Society, p. 93-108.

Goodbred, S.L., Gilliom, R.J., Gross, T.S., Denslow, N.P., Bryant, W.L., and Schoeb, T.R., 1997, Reconnaissance of 17ß-estradiol, 11-ketotestosterone, vitellogenin, and gonad histopathology in common carp of United States streams: potential for contaminant-induced endocrine disruption: U.S. Geological Survey, Open-File Report 96-627, 47 p.

Grady, A.W., McLaughlin, R.M., Caldwell, C.W., Schmitt, C.J., and Stalling, D.L., 1992, Flow cytometry, morphometry and histopathology as biomarkers of benzo[ $a]$ pyrene exposure in brown bullheads (Ameiurus nebulosus): Journal of Applied Toxicology, v. 12, no. 3, p. 165-177.

Guillette, L.J., Jr., Gross, T.S., Masson, G.R., Matter, J.M., Percival, H.F., and Woodward, A.R., 1994, Developmental abnormalities of the gonad and abnormal sex hormone concentrations in juvenile alligators from contaminated and control lakes in Florida: Environmental Health Perspectives, v. 102 , p. $680-688$.

Guillette, L.J., Jr., Gross,T.S., Arnold, S.F., and McLachlan, J.A., 1996, Ecoestrogens and embryos - is this a scientific basis for concern?: Animal Reproductive Science, v. 42, p. 13-24.

Haas, R.E., and Recksiek, C.W., 1995, Age verification of winter flounder in Narragansett Bay: Transactions of the American Fisheries Society, v.124, p. 103-111.

Hamelink, J.L., Waybrant, R.C., and Ball, R.C., 1971, A proposal: Exchange equilibria control the degree chlorinated hydrocarbons are biologically magnified in lentic environments: Transactions of the American Fisheries Society, v. 100, p. 207-214. 
Hamilton, S.J., 2004, Review of selenium toxicity in the aquatic food chain: Science of the Total Environment, v. 326, p. 1-31.

Heaton, S.N., Bursian, S.J., Giesy, J.P., Tillitt, D.E., Render, J.A., Jones, P.D., Verbrugge, D.A., Kubiak, T.J., and Aulerich, R.J., 1995, Dietary exposure of mink to carp from Saginaw Bay, Michigan: 2. Hematology and liver pathology: Archives of Environmental Contamination and Toxicology, v. 29 , p. 411-417.

Heinz, G.H., 1979, Methylmercury: reproductive and behavioral effects on three generations of mallard ducks: Journal of Wildlife Management, v. 43, p. 394-401.

Heinz, G.H., and Hoffman, D.J., 1998, Methylmercury chloride and selenomethionine interactions on health and reproduction in mallards: Environmental Toxicology and Chemistry, v. 17, p. 139-145.

Hermanutz, R.O., Allen, K.N., Roush, T.H., and Hedtke, S., 1992, Effects of elevated selenium concentrations on bluegills (Lepomis macrochirus) in outdoor experimental streams: Environmental Toxicology and Chemistry, v. 11; p. 217-224.

Hileman, B., 1994, Environmental estrogens linked to reproductive abnormalities, cancer: Chemical and Engineering News, v. 72, no. 5, p. 19-23.

Hinck, J.E., Schmitt, C.J., Bartish, T.M., Denslow, N.D., Blazer, V.S., Anderson, P.J., Coyle, J.J., Dethloff, G.M., and Tillitt, D.E., 2004, Biomonitoring of Environmental Status and Trends (BEST) Program: Environmental contaminants and their effect on fish in the Columbia River basin: U.S. Geological Survey, Biological Resources Division, Scientific Investigations Report nr 2004-5154, 125 p.

Hinck, J.E., Nicks, D.K., and Tillitt, D.E., 2003, Determination of enzymatic activity of cytochrome P450IAI in fish collected from the Yukon River basin as part of the 2002 Biomonitoring of Environmental Status and Trends (BEST) Program: Report from the Biochemistry and Physiology Branch, U.S. Geological Survey, Columbia Environmental Research Center, Columbia, MO, 65201, report nr FY 200330-02, 17 p.

Hinton, D.E., Baumann, P.C., Gardner, G.R., Hawkins, W.E., Hendricks, J.D., Murchelano, R.A., and Okihiro, M.S., 1992, Histopathologic biomarkers, in Huggett, R.J., Kimerle, R.A., Mehrle, P.M., Jr., and Bergman, H.A., eds., Biomarkers: biochemical, physiological, and histological markers of anthropogenic stress: Chelsea, MI, Lewis Publishers, p. 155-210.

Hinton, D.E., 1993, Toxicologic histopathology of fishes: a systemic approach and overview, in Couch, J.A., and Fournie, J.W., eds., Pathobiology of marine and estuarine organisms: Boca Raton, FL, CRC Press.
Holcombe, G.W., Benoit, D.A., Leonard, E.N., and McKim, J.M., 1976, Long-term effects of lead exposure on three generations of brook trout (Salvelinus fontinalis): Journal of Fisheries Research Board of Canada, v. 33, p. 1731-1741.

Hopkins, C.L., Solly, S.R, and Ritchie, A.R., 1969, DDT in trout and its possible effect on reproductive potential: New Zealand Journal of Marine Freshwater Research, v. 3, p. 220-229.

Hornshaw, T.C., Aulerich, R.J., and Johnson, H.E., 1983, Feeding great lakes fish to mink: effects on mink and accumulation and elimination of PCBs by mink: Journal of Toxicology and Environmental Health, v. 11, p. 933-946.

Hutchinson, T.H., and Manning, M.J., 1996, Seasonal trends in serum lysozyme activity and total protein concentration in dab (Limanda limanda L.) sampled from Lyme Bay, U. K.: Fish \& Shellfish Immunology, v. 6, p. 473-482.

Jarvinen, A.W., Hoffman, M.J., and Thorslund, T.W., 1976, Toxicity of DDT food and water exposure to fathead minnows: Duluth MN: U.S. Environmental Protection Agency. EPA-600/3-76/114.

Jarvinen, A.W., Hoffman, M.J., and Thorslund, T.W., 1977, Long-term effects of DDT food and water exposure on fathead minnows (Pimephales promelas): Journal of Fisheries Research Board of Canada, v. 34, p. 2089-2103.

Jarvinen, A.W., and Ankley, G.T., 1999, Linkage of effects to tissue residues: development of a comprehensive database for aquatic organisms exposed to inorganic and organic chemicals: Pensacola, FL, SETAC Press, 358 p.

Jearld, A., Jr., 1983, Age determination, in Nielsen, L.A. and Johnson, D.L., eds., Fisheries techniques: Bethesda, Maryland, American Fisheries Society, p. 301-324.

Jewett, S.C., Zhang, X., Naidu, A.S., Kelley, J.J., Dasher, D., and Duffy, L.K., 2003, Comparison of mercury and methylmercury in northern pike and Arctic grayling from western Alaska rivers: Chemosphere, v. 50, p. 383-392.

Jobling, S., Nolan, M., Tyler, C.R., Brighty, G., and Sumpter, J.P., 1998, Widespread sexual disruption in wild fish: Environmental Science \& Technology, v. 32, p. 2498-2506.

Johnson, H.E., and Pecor, C., 1969, Coho salmon mortality and DDT in Lake Michigan, $34^{\text {th }}$ North American Wildlife Conference: proceedings; 1969 Mar 2-5, Washington D.C., p. 159-166.

Johnson, W.L., and Finley, M.T., 1980, Handbook of acute toxicity of chemicals to fish and aquatic invertebrates: summaries of toxicity tests conducted at Columbia National Fisheries Research Lab, 1965-78: U.S. Fish and Wildlife Service, Resource Publication 137, 98 p. 
Johnson, L.L., Casillas, E., Collier, T.K., McCain, B.B., and Varanasi, U., 1988, Contaminant effects on ovarian development in English sole (Parophyrs vetulus) from Puget Sound, Washington: Canadian Journal of Fisheries and Aquatic Sciences, v. 45, no. 12, p. 2133-2146.

June, F.C., 1970, Atresia and year-class abundance of northern pike, Esox lucius, in two Missouri River impoundments: Journal of Fisheries Research Board of Canada, v. 27, p. 587-591.

June, F.C., 1977, Reproductive patterns in seventeen species of warmwater fishes in a Missouri River reservoir: Environmental Biology of Fishes, v. 2, p. 285-296.

Kaiser, K.L., 1987, The rise and fall of mirex: Environmental Science \& Technology, v. 12, p. 520-528.

Kania, H. J. and O'Hara, J., 1974, Behavioral alterations in a simple predator-prey system due to sublethal exposure to mercury: Transactions of the American Fisheries Society, v. 103, p. 134-136.

Keith, L.H., 1991, Environmental sampling and analysis, a practical guide: Lewis Publishers, Chelsea, MI, 160 p.

Kennedy, S.W., and Jones, S.P., 1994, Simultaneous measurement of cytochrome P4501A catalytic activity and total protein concentration with a fluorescence plate reader: Analytical Biochemistry, v. 222, p. 217-223.

Khan, R.A., and Payne, J.F., 2002a, Some factors influencing EROD activity in winter flounder (Pleuronectes americanus) exposed to effluent from a pulp and paper mill: Chemosphere v. 46, p. 235-239.

Khan, R.A., and Payne, J.F., 2002b, Factors influencing EROD activity in feral winter flounder (Pleuronectes americanus) exposed to effluent from a pulp and paper mill in Newfoundland: Bulletin of Environmental Contamination and Toxicology, v. 68, p. 794-800.

Kiceniuk, J.W., and Khan, R.A., 1987, Effect of petroleum hydrocarbons on Atlantic cod, Gadhus morhua, following chronic exposure: Canadian Journal of Zoology, v. 65, p. 490-494.

Kidd, K.A., Schindler, D.W., Hesslein, R.H., and Muir, D.C., 1998, Effects of trophic position and lipid on organochlorine concentrations in fishes from subarctic lakes in Yukon Territory: Canadian Journal of Fish and Aquatic Science, v. 55 , p. $869-881$.

Kirubagaran, R., and Joy, K.P., 1988, Toxic effects of mercuric chloride, methylmercuric chloride, and emisan 6 (an organic mercurial fungicide) on ovarian recrudescence in the catfish Clarias batrachus (L.): Bulletin of Environmental Contamination and Toxicology, v. 41, p. 902-909.
Kloepper-Sams, P.J., and Benton, E., 1994, Exposure of fish to biologically treated bleached-kraft effluent II, Induction of hepatic cytochrome P4501A in mountain whitefish (Prosopium williamsoni) and other species: Environmental Toxicology and Chemistry, v. 13, no. 9, p. 1483-1496.

Krykhtin, M.L., 1976, Morphological and physiological indicators of the Kaluga sturgeon, Huso dauricus, from the Amur Esturary: Journal of Ichthyology, v. 16, p. 259-270.

Langard, S., and Norseth T., 1986, Chromium, in Friberg L., Nordberg G.F., and Vouk, V., eds., Handbook of the toxicology of metals, $2^{\text {nd }}$ edition, volume II, Specific Metals: Elsevier Science, Amsterdam, p. 185-205.

Lemly, A.D., 1996, Selenium in aquatic organisms, in Beyer, W.N., Heinz, G.H., and Redmon-Norwood, A.W., eds., Environmental contaminants in wildlife: interpreting tissue concentrations: Boca Raton, FL, Lewis Publishers, p. 427445.

Lemly, A.D., 2002, Symptoms and implications of selenium toxicity in fish: the Belews Lake case example: Aquatic Toxicology, v. 57, p. 39-49.

Leonard, P.M., and Orth, D.J., 1986, Application and testing of an index of biotic integrity in small, coolwater streams: Transactions of the American Fisheries Society, v. 115, p. 401-414.

Lockhart, W.L., and Metner, D.A., 1992, Applications of hepatic mixed function oxidase enzyme activities to northern freshwater fish, I, burbot, Lota lota: Marine Environmental Research, v. 34, p. 175-180.

Lorenzen, A., and Kennedy, S.W., 1993, A fluorescence-based protein assay for use with a microplate reader: Analytical Biochemistry, v. 214, p. 346-348.

Luna, L.G., 1992, Histopathological methods and color atlas of special stains and tissue artifacts: Gaithersburg, MD, American Histolabs, Inc.

Macdonald, R.W., Harner, T., Fyfe, J., Loeng, H., and Weingartner, T., 2003, AMAP Assessment 2002: the influence of global change on contaminant pathways to, within, and from the Arctic: Arctic Monitoring and Assessment Programme (AMAP), Oslo, Norway, 65 p.

Macek, K.J., 1968, Reproduction in brook trout (Salvelinus fontinalis) fed sublethal concentrations of DDT: Journal of Fisheries Research Board of Canada, v. 25, p. 1787-1796.

Macek, K.J., Rodgers, C.R., Stalling, D.L., and Korn, S., 1970, The uptake, distribution and elimination of dietary ${ }^{14} \mathrm{C}$ DDT and ${ }^{14} \mathrm{C}$-Dieldrin in rainbow trout: Transactions of the American Fisheries Society, v. 99, p. 689-695. 
Machala, M., Nezveda, K., Petřivalsky, M., běta Jarošová, A., Piačka, V., and Svobodová, Z., 1997, Monooxygenase activities in carp as biochemical markers of pollution by polycyclic and polyhalogenated aromatic hydrocarbons: choice of substrates and effects of temperature, gender, and capture stress: Aquatic Toxicology, v. 37, p. 113-123.

Mayer, F.L., Jr., Merhle, P.M., Jr., and Dwyer, W.P., 1975, Toxaphene effects on reproduction, growth, and mortality of brook trout, Duluth MN: U.S. Environmental Protection Agency, EPA-600/3-75/013.

Mayer, F.L., Jr., Mehrle, P.M., and Crutcher, P.L., 1978, Interactions of toxaphene and vitamin $\mathrm{C}$ in channel catfish: Transaction of the American Fisheries Society, v. 107, p. 326-333.

McCain, B.B., Chan, S.L., Krahn, M.M., Brown, D.W., Myers, M.S., Landahl, J.T., Pierce, S., Clark, R.C., Jr., and Varanasi, U., 1992, Chemical contamination and associated fish diseases in San Diego Bay: Environmental Science \& Technology, v. 26, no. 4, p. 725-733.

McDonald, K.K., Gross, T.S., Denslow, N.D., Densmore, C., and Blazer, V.S., 2002, Reproductive biomarkers, in Schmitt, C.J., ed., Biomonitoring of Environmental Status and Trends (BEST) Program: environmental contaminants and their effects on fish in the Mississippi River basin: U.S. Geological Survey, Biological Resources Division, Biological Science Report nr 2002-0004, p. 135-170.

McGreachy, S.M., and Dixon, D.G., 1990, Effect of temperature on the chronic toxicity of arsenate to rainbow trout (Oncorhynchus mykiss): Canadian Journal of Fisheries and Aquatic Science, v. 47, p. 2228-2234.

McGreachy, S.M., and Dixon, D.G., 1992, Whole-body arsenic concentrations in rainbow trout during acute exposure to arsenate: Ectoxicology and Environmental Safety, v. 24. p. 301-308.

McKim, J.M., Olson, G.F., Holcombe, G.W., and Hunt, E.P., 1976, Long-term effects on methlymercuric chloride on three generations of brook trout (Salvelinus fontinalis): Toxicity, accumulation, distribution, and elimination: Journal of Fisheries Research Board of Canada, v. 33, p. 2726-2739.

McMaster, M.E., van der Kraak, G.J., Portt, C.B., Munkittrick, K.R., Sibley, P.K., Smith, I.R., and Dixon, D.G., 1991, Changes in hepatic mixed-function oxygenase (MFO) activity, plasma steroid levels and age at maturity of a white sucker (Catostomus commersoni) population exposed to bleached kraft pulp mill effluent: Aquatic Toxicology, v. 21, p. 199-218.
Miller, P.A., Munkittrick, K.R., and Dixon, D.G., 1992, Relationship between concentrations of copper and zinc in water, sediment, benthic invertebrates, and tissues of white sucker (Catostomus sommersoni) at metal-contaminated sites: Canadian Journal of Fisheries and Aquatic Sciences, v. 49 , p. $978-984$.

Möller, H., 1985, A critical review on the role of pollution as a cause of fish diseases, in Ellis, A.E., ed., Fish and shellfish pathology: New York, NY, Academic Press, p. 169-182.

Mueller, K.A., Snyder-Conn, E., and Scannell, P.O., 1995, Metal and metalloid contaminants in water, sediments, fish, and mammals of Kanuti National Wildlife Refuge, Alaska, 1985-1990: Fish and Wildlife Service Technical Report NAES-TR-95-02, Fairbanks, AK, 125 p.

Mueller, K.A., Snyder-Conn, E., and Bertram, M., 1996, Water quality and metal and metalloid contaminants in sediments and fish of Koyukuk, Nowitna, and the Northern unit of Innoko National Wildlife Refuges, Alaska, 1991: Fish and Wildlife Service Technical Report NAES-TR-96-03, Fairbanks, AK, 79 p.

Mueller, K.A., and Matz, A.C., 2000, Organochlorine concentrations in burbot (Lota lota) livers from Fairbanks, Alaska, and Kanuti, Tetlin, and Yukon Flats National Wildlife Refuges, Alaska, 1998: Fish and Wildlife Service, Fairbanks, AK, 49 p.

Mueller, K.A., and Matz, A.C., 2002, Water quality, and metal and metalloid concentrations in water, sediment, and fish tissues from Innoko National Wildlife Refuge Alaska, 19951997: Fish and Wildlife Service Technical Report NAESTR-02-01, Fairbanks, AK, 155 p.

Muir, D., Braune, B., DeMarch, D., Norstrom, R., Wagemann, R., Lockhart, L., Hargrave, B., Bright, D., Addison, R., Payne, J., and Reimer, K., 1999, Spatial and temporal trends and effects of contaminants in the Canadian Arctic marine ecosystem: a review: Science of the Total Environment, v. 230, p. 83-144.

Muir, D., and de Boer, J., 1993, Toxaphene, analytical chemistry: Chemosphere, v. 27 , no. 10 , p. 1827-1834.

Munkittrick, K.R., and Dixon, D.G., 1988, Growth, fecundity, and energy stores of white sucker (Catostomus commersoni) from lakes containing elevated levels of copper and zinc: Canadian Journal of Fisheries and Aquatic Sciences, v. 45, p. $1355-1365$. 
Myers, M.S., Stehr, C.M., Olson, O.P., Johnson, L.L., McCain, B.B., Chan, S., and Varanasi, U., 1994, Relationships between toxicopathic hepatic lesions and exposure to chemical contaminants in English sole (Pleuronectes vetulus), starry flounder (Platichthys stellatus), and white croaker (Genyonemus lineatus) from selected marine sites on the Pacific Coast, USA; Environmental Health Perspectives, v.102, p. 200-215.

Myers, M.S., and Fournie, J.W., 2002, Histopathological biomarkers as integrators of anthropogenic and environmental stressors, in Adams, S.M. ed., Biological indicators of aquatic ecosystem stress: Bethesda, MD, American Fisheries Society, p. 221-288.

Nagahama, Y., 1983, The functional morphology of teleost gonads, in Hoar, W.S., Randall, D.J., and Donaldson, E.M., eds., Fish physiology, vol IX: Orlando, FL, Academic Press, Inc., p. 223-264.

Newell, A.J., Johnson, D.W., and Allen, L.K., 1987, Niagara River biota contamination project: fish flesh criteria for piscivorous wildlife: New York State Department of Environmental Conservation, Division of Fish and Wildlife, Bureau of Environmental Protection, Technical Report 87-3, $180 \mathrm{p}$.

Niimi, A.J, 1996, PCBs in aquatic organisms, in Beyer, W.N., Heinz, G.H., and Redmon-Norwood, A.W., eds., Environmental contaminants in wildlife: interpreting tissue concentrations: Boca Raton, FL, Lewis Publishers, p. 49-72.

Northern Contaminants Program (NCP), 2003, Canadian Arctic Contaminants Assessment Report Phase II: Indian and Northern Affairs Canada, QS-8526-010-EE-A1.

Nosek, J.A., Craven, S.R., Sullivan, J.R., Hurley, S.S., and Peterson, R.E., 1992, Toxicity and reproductive effects of 2,3,7,8-tetrachlorodibenzo- $p$-dioxin in ring-necked pheasant hens: Journal of Toxicology and Environmental Health, v. 35, p. 187-198.

Oakes, K.D., McMaster, M.E., and Van der Kraak, G.J., 2004, Oxidative stress responses in longnose sucker (Catostomus catostomus) exposed to pulp and paper mill and municipal sewage effluents: Aquatic Toxicology, v. 67, p. 255-271.

Peakall, D.B., 1996, Dieldrin and other cyclodiene pesticides in wildlife, in Beyer, W.N., Heinz, G.H., and Redmon-Norwood, A.W., eds., Environmental contaminants in wildlife: interpreting tissue concentrations: Boca Raton, FL, Lewis Publishers, p. 73-98.

Peters, L.D., and Livingstone, D.R., 1995, Studies on cytochrome P4501A in early and adult life stages of turbot (Scophthalmus maximus L.): Marine Environmental Research, v. 39, p. 5-9.
Pluta, H.J., 1993, Investigations on biotransformation (mixed function oxygenase activities) in fish liver, Heidelberg, Germany, Sept 25-27, 1991, Fish: Ecotoxicology and Ecophysiology, Proceedings of an International Symposium.

Pohl, R.J., and Fouts, J.R., 1980, A rapid method for assaying the metabolism of 7-ethoxyresorufin by microsomal subcellular fractions: Analytical Biochemistry, v. 107, p. 150-155.

Rhead, M.M., and Perkins, J.M., 1984, An evaluation of the relative importance of food and water as sources of p,p'-DDT to the goldfish Carassius auratus (L.): Water Research, v. 18, p. 719-725.

Rodriguez, J.N., Oteme, Z.J., and Hem, S., 1995, Comparative study of vitellogenesis of two African catfish species Chrysichthys nigrodigitatus (Claroteidae) and Heterobranchus longifilis (Clariidae): Aquatic Living Resources, v. 8, p. 291-296.

Ruklov, F.N., 1979, A description of some morphophysiological characters of salmon of the genus Oncorhynchus: Journal of Ichthyology, v. 19, p. 23-40.

Salomone, P., and Bergstrom, D.J., 2004, Yukon river summer chum Salmon stocks status and action plan: Regional Information Report No. 3A04-03, Alaska Department of Fish and Game Division of Commercial Fisheries, Anchorage, Alaska.

Scannell, P., 1997, Contaminant concentrations in sediment and plants of placer mining settling ponds from interior Alaska: Fish and Wildlife Service Technical Report NAESTR-97-01.

Scheuhammer, A.W., Wong, A.H., and Bond, D., 1998, Mercury and selenium accumulation in common loons (Gavia immer) and common mergansers (Mergus merganser) from eastern Canada: Environmental Toxicology and Chemistry, v. 17 , p. 197-201.

Schmitt, C.J., and Winger, P.V., 1980, Factors controlling the fate of pesticides in rural watersheds of the Lower Mississippi river alluvial valley: Transactions of the North American Wildlife and Natural Resources Conference, v. 45, p. 354-375.

Schmitt, C.J., Zajicek, J.L., and Ribick, M.A., 1985, National Pesticide Monitoring Program: Residues of organochlorine chemicals in freshwater fish, 1980-81: Archives of Environmental Contamination and Toxicology, v. 14, p. 225-260. 
Schmitt, C.J., Blazer, V.S., Dethloff, G.M., Tillitt, D.E., Gross, T.S., Bryant, W.L., Jr., DeWeese, L.R., Smith, S.B., Goede, R.W., Bartish, T.M., and Kubiak, T.J., 1999a, Biomonitoring of Environmental Status and Trends (BEST) Program: field procedures for assessing the exposure of fish to environmental contaminants: U.S. Geological Survey, Biological Resources Division, Information and Technology Report nr 1999-0007, 68 p.

Schmitt, C.J., Zajicek, J.L., May, T.W., and Cowman, D.F., 1999b, Organochlorine residues and elemental contaminants in U.S. freshwater fish, 1976-1986: National Contaminant Biomonitoring Program: Reviews of Environmental Contamination and Toxicology, v. 162, p. 43-104.

Schmitt, C.J., and Dethloff, G.M., eds. 2000, Biomonitoring of Environmental Status and Trends (BEST) program: selected methods for monitoring chemical contaminants and their effects in aquatic ecosystems: U.S. Geological Survey, Information and Technology Report nr 2000-0005, 81 p.

Schmitt, C.J., ed., 2002a, Biomonitoring of Environmental Status and Trends (BEST) Program: environmental contaminants and their effects on fish in the Mississippi River basin: U.S. Geological Survey, Biological Resources Division, Biological Science Report nr 2002-0004, 241 p.

Schmitt, C.J., 2002b, Organochlorine chemical residues in fish from the Mississippi River basin, 1995: Archives of Environmental Contamination and Toxicology, v. 43, p. 81-97.

Schmitt, C.J., Tillitt, D.E., and Whyte, J.J., 2002a, Accumulative contaminants, dioxin-equivalent concentrations by H4IIE bioassay, and ethoxyresorufin $O$-deethylase (EROD) activity, in Biomonitoring of Environmental Status and Trends (BEST) Program: environmental contaminants and their effects on fish in the Mississippi River basin. U.S. Geological Survey, Biological Resources Division, Biological Science Report nr 2002-0004, p. 27-88.

Schmitt, C.J, Dethloff, G.M., Hinck, J.E., Bartish, T.B., Blazer, V.S., Coyle, J.J., Denslow, N.D., and Tillitt, D.E., 2004, Biomonitoring of Environmental Status and Trends (BEST) Program: environmental contaminants and their effects on fish in the Rio Grande basin: U.S. Geological Survey, Biological Resources Division, Scientific Investigations Report nr 2004-5108, 117 p.

Schrank, C.S., Cormier, S.M., and Blazer, V.S., 1997, Contaminant exposure, biochemical, and histopathological biomarkers in white suckers from contaminated and references sites in the Sheboygan River, Wisconsin: Journal of Great Lakes Research, v. 23, p. 119-130.

Schreck, C.B., and Hopwood, M.L., 1974, Seasonal androgen and estrogen patterns in the goldfish Carassius auratus: Transactions of the American Fisheries Society, v. 103, p. 375-378.
Schultz, R., and Hermanutz, R., 1990, Transfer of toxic concentrations of selenium from parent to progeny in the fathead minnow (Pimephales promelas): Bulletin of Environmental Contamination and Toxicology, v. 45, p. 568-573.

Schumm, S.A., and Winkley, B.R., 1994, The character of large alluvial rivers, in Schumm, S.A., and Winkley, B.R., eds., The variability of large alluvial rivers: New York, American Society of Civil Engineers, p. 1-9.

Segner, H., Scholz, S., and Bohm, R., 1995, Carp (Cyprinus carpio) hepatocytes in primary culture: morphology and metabolism, in Dorange D, Guguen GC, Samain JF, eds. La biologie des protozoaires, invertebres et poisons: modeles experimentaux in vitro et applications [Biology of protozoans, invertebrates, and fish: in vitro experimental models and applications] Brest, France: Plouzane (France), Ifremer, p. 77-82.

Servos, M.R., 1999, Review of the aquatic toxicity, estrogenic responses and bioaccumulation of alkylphenols and alkylphenol polyethoxylates: Water Quality Research Journal of Canada, v. 34, p. 123-177.

Shubat, P.J., and Curtis, L.R., 1986, Ration and toxicant preexposure influence dieldrin accumulation by rainbow trout (Salmo gairdneri): Environmental Toxicology and Chemistry, v. 5, p. 69-77.

Sindermann, C.J., 1979, Pollution-associated diseases and abnormalities in fish and shellfish: a review: Fishery Bulletin, v. 76, p. 717-749.

Snarksi, V.M. and Olson, G.F., 1982, Chronic toxicity and bioaccumulation of mercuric chloride in the fathead minnow (Pimephales promelas): Aquatic Toxicology, v. 2, p. 143-156.

Snyder-Conn, E., Bertram, M., and Scannell, P., 1992, Contaminant data for water, sediments, and fish of the Koyukuk National Wildlife Refuge and the Northern Unit of Innoko National Wildlife Refuge: Fish and Wildlife Service Technical Report NAES-TR-92-04, Fairbanks, AK, 13 p.

Snyder-Conn, E., 1992, Contaminant investigation of fish in Lake Minchumina, Alaska: Fish and Wildlife Service Technical Report NAES-TR-92-03, Fairbanks, AK, 13 p.

So, Y.P., Idler, D.R., Wilson, C.E., and Crim, L.W., 1989, Seasonal variation of plasma vitellogenin and steroid levels in captive female Atlantic salmon kelt, and their changes under re-maturation treatment of testosterone: Bulletin of the Aquaculture Association of Canada, v. 89, p. 31.

Spehar, R.L., 1976, Cadmium and zinc toxicity to flagfish (Jordanella floridae): Journal of Fisheries Research Board of Canada, v. 33, p. 1939-1945. 
Stehr, C.M., Myers, M.S., Johnson, L.L., Spencer, S., Stein, J.E., 2003, Toxicopathic liver lesions in English sole and chemical contaminant exposure in Vancouver Harbour, Canada: Marine Environmental Research, v. 57, p. 55-74.

Stouthart, X., Haans, J., Lock, R., and Wendelaar Bonga, S., 1996, Effects of water pH on copper toxicity to early life stages of the common carp (Cyprinus carpio): Environmental Toxicology and Chemistry, v. 15, p. 376-383.

Summers, J.K., Macauley, J.M., Heitmuller, P.T., Engle, V.D., Adams, A.M., and Brooks, G.T., 1993, Statistical summary: EMAP-Estuaries Lousianain Province-1991: U.S. Environmental Protection Agency, Office of Research and Development, EPA/620/R-93/007; PB94-117488, 101 p.

Sun, L., and Jeng, S., 1998, Comparative zinc concentrations in tissues of common carp and other aquatic organisms: Zoological Studies v. 37, p. 184-190.

Talbot, S.S., and Markon, C.J., 1986, Vegetation mapping of the Nowitna National Wildlife Refuge, Alaska using Landsat MSS digital data: Photogrammetric Engineering and Remote Sensing, v. 52, no. 6, p. 791-799.

Tao, Y., Berlinsky, D.L., and Sullivan, C.V., 1996, Characterization of a vitellogenin receptor in white perch (Morone americana): Biology of Reproduction, v. 55, no. 3, p. 646656.

TAPS Owners, 2001, Environmental report for trans Alaska pipeline system right-of-way renewal: Trans Alaska Pipeline System Owners, Draft 2/15/01, Anchorage, Alaska.

Teh, S.J., and Hinton, D.E., 1993, Detection of enzyme histochemical markers of hepatic preneoplasia and neoplasia in medaka (Oryzias latipes): Aquatic Toxicology, v. 24, p. 163-182.

Tetra Tech Inc., 1996, Lower Columbia River Bi-State Program: the health of the river 1990-1996: Integrated Technical Report 0253-01, Redmond, WA, 109 p.

Thompson, D.R., 1996, Mercury in birds and terrestrial mammals, in Beyer, W.N. Heinz, G.H., and Redmon-Norwood, A.W., eds., Environmental contaminants in wildlife: interpreting tissue concentrations: Boca Raton, FL, Lewis Publishers, p. 341-356.

Tillitt, D.E., Giesy, J.P., and Ankley, G.T., 1991, Characterization of the H4IIE rat hepatoma cell bioassay as a tool for assessing toxic potency of planar halogenated hydrocarbons in environmental samples: Environmental Science \& Technology, v. 25, no. 1, p. 87-92.
Tillitt, D.E., Gale, R.W., Meadows, J.C., Zajicek, J.L., Peterman, P.H., Heaton, S.N., Jones, P.D., Bursian, S.J., Kubiak, T.J., Giesy, J.P., and Aulerich, R.J., 1996, Dietary exposure of mink to carp from Saginaw Bay 3, Characterization of dietary exposure to planar halogenated hydrocarbons, dioxin equivalents, and biomagnification: Environmental Science \& Technology, v. 30, no. 1, p. 283-291.

Toppari, J., Larsen, J., Christiansen, P., Giwercman, A., Grandjean, P., Guillette, L.J. Jr., Jegou, B., Jensen, T.K., Jouannet, P., Keiding, N., Leffers, H., McLachlan, J.A., Meyer, O., Muller, J., Rajpert-De Meyts, J., Scheike, T., Sharpe, R., Sumpter, J., and Skakkebaek, N.E., 1996, Male reproductive health and environmental xenoestrogens: Environmental Health Perspectives, v. 104. p. 741-803.

Treasurer, J.W., and Holliday, F.G.T., 1981, Some aspects of the reproductive biology of perch Perca flaviatilis L.: A histological description of the reproductive cycle: Journal of Fish Biology, v. 18, p. 359-376.

Tyler, A.V., and Dunn, R.S., 1976, Ration, growth, and measures of somatic and organ condition in relation to meal frequency in winter flounder, Pseudopleuronectes americanus, with hypotheses regarding population homeostasis: Journal of the Fisheries Research Board of Canada, v. 33, p. 63-75.

Tyler, C.R., Jobling, S., and Sumpter, J.P., 1998, Endocrine disruption in wildlife: A critical review of the evidence: Critical Reviews in Toxicology, v. 28, p. 319-361.

U.S. Army Corps of Engineers (USACE), 1999, Location of formerly used defense sites in the state of Alaska: U.S. Army Corps of Engineers Cold Regions Research and Engineering Laboratory, Hanover, NH, GIS Digital Data.

U.S. Army Corps of Engineers (USACE), 2003, Formerly used defense sites geographic information system: Army Corps of Engineers Cold Regions Research and Engineering Laboratory, Hanover, $\mathrm{NH},<h t t p: / / w w w . p o a . u s a c e$.army. mil/fuds/index.htm>, (accessed 10 October 2003).

U.S. Bureau of Land Management (USBLM), 2002, Final environmental impact statement renewal of the federal grant for the trans-Alaska pipeline system right-of-way: U.S. Department of the Interior, Bureau of Land Management, BLM/AK/PT-03/005+2880+990, 217 p. + appendices.

U.S. Environmental Protection Agency (USEPA), 1984, Ambient water quality criteria for arsenic: USEPA, EPA/440/5-84-037.

U.S. Environmental Protection Agency (USEPA), 1995, EPA superfund record of decision: Artic surplus: EPA ID AKD980988158, Fairbanks, Alaska, U.S. Environmental Protection Agency, EPA/ROD/R10-95/127, 134 p. 
U.S. Environmental Protection Agency (USEPA), 1998, EPA superfund record of decision amendment: Eielson Air Force Base, EPA ID AK1570028646, Fairbanks, AK, U.S. Environmental Protection Agency, EPA/AMD/R10-98/185, 16 p.

U.S. Environmental Protection Agency (USEPA), 1999, EPA superfund record of decision: Fort Wainwright, EPA ID AK6210022426, Fort Wainwright, AK, U.S. Environmental Protection Agency, EPA/ROD/R10-99/036, 183 p.

U.S. Environmental Protection Agency (USEPA), 2003a, 2002, National listing of fish and wildlife advisories (NLFWA) database: <http://map1.epa.gov/scripts/.esrimap? name $=$ Listing \& $C m d=$ Map $>$, (queried August 2003).

U.S. Environmental Protection Agency (USEPA), 2003b, Toxic release inventory (TRI) database: U.S. Environmental Protection Agency, Envirofacts Data Warehouse, <http:// www.epa.gov/enviro/html/tris/adhoc.html $>$, (accessed 02 October 2003).

U.S. Environmental Protection Agency (USEPA), 2003c, Permit Compliance System (PCS) Database: U.S. Environmental Protection Agency, Envirofacts Data Warehouse, $<$ http://www.epa.gov/enviro/html/pcs/adhoc.html> (accessed 02 October 2003).

U.S. Environmental Protection Agency (USEPA), 2003d, Comprehensive Environmental Response, Compensation, and Liability Information System (CERCLIS): U.S. Environmental Protection Agency, Envirofacts Data Warehouse, <http://www.epa.gov/enviro/html/cerclis/cerclis_query. html>, (accessed 06 October 2003).

U.S. Environmental Protection Agency (USEPA), 2003e, Explanation of significant differences for the Artic surplus superfund site: EPA ID AKD980988158 Fairbanks, AK, EPA/ESD/R10-03/009, 19 p.

U.S. Fish and Wildlife Service (USFWS), 1986, Trace elements from placer mining in Alaskan streams are toxic to young salmonids: U.S. Fish and Wildlife Service Research Information Bulletin, \#98.

U.S. Fish and Wildlife Service (USFWS), 1991, Young salmon are sensitive to arsenite and mercury released by placer mining activities: U.S. Fish and Wildlife Service Research Information Bulletin, \#30.

U.S. Geological Survey (USGS), 2001, Water quality in the Yukon River basin: U.S. Department of the Interior, U.S. Geological Survey, factsheet FS-050-01, 8 p. van den Heuvel, M.R., Munkittrick, K.R., van der Kraak, G.J., Servos, M.R., and Dixon, D.G., 1995, Hepatic 7-ethoxyresorufin- $O$-deethylase activity, plasma steroid hormone concentrations, and liver bioassay-derived 2,3,7,8-TCDD toxic equivalent concentrations in wild white sucker (Catostomus commersoni) caged in bleached kraft pulp mill effluent: Canadian Journal of Fisheries and Aquatic Sciences, v. 52, no. 7, p. 1339-1350.

Wahrhaftig, C., 1965, Physiographic divisions of Alaska: U.S. Geological Survey Professional Paper 482, 51 p., 6 plates.

Walker, M.A., Cook, P.M., Butterworth, B.C., Zabel, E.W., and Peterson, R.E., 1996, Potency of a complex mixture of polychlorinated dibenzo- $p$-dioxin, dibenzofuran, and biphenyl congeners compared 2,3,7,8-tetrachlorodibenzo- $p$ dioxin in causing fish early life stage mortality: Fundamental and Applied Toxicology, v. 30, p. 178-187.

West R.L., and Deschu, N.A., 1984, Kantishna Hills heavy metals investigations, Denali National Park, 1983: Fish and Wildlife Service and National Park Service Interagency Agreement nr 14-16-007-85-5524.

White, A., and Fletcher, T.C., 1985, Seasonal changes in serum glucose and condition of the plaice, Pleuronectes platessa (L): Journal of Fish Biology, v. 26, p. 755-764.

Whyte, J.J., Jung, R.E., Schmitt, C.J., and Tillitt, D.E., 2000, Ethoxyresorufin $O$-deethylase (EROD) activity in fish as a biomarker of chemical exposure: Critical Reviews in Toxicology, v. 30, no. 4, p. 347-570.

Whyte, J.J., Schmitt, C.J., and Tillitt, D.E., 2004, The H4IIE cell bioassay as an indicator of dioxin-like chemicals in wildlife and the environment: Critical Reviews in Toxicology, v. 34, no.1, p.1-83.

Wiener, J.G., and Spry, D.J., 1996, Toxicological significance of mercury in freshwater fish, in Beyer, W.N., Heinz, G.H., and Redmon-Norwood, A.W., eds., Environmental contaminants in wildlife: interpreting tissue concentrations: Boca Raton, FL, Lewis Publishers, p. 297-339.

Wiener, J.G., Krabbenhoft, D.P., Heinz, G.H., Scheuhammer, A.M., 2002, Ecotoxicology of mercury, Ch. 16, in Hoffman, D.J., Rattner, B.A., Burton, G.A., Jr., and Cairns, J., Jr., eds. Handbook of ecotoxicology, $2^{\text {nd }}$ edition.

Williams, T.G., Lockhart, W.L., Metner, D.A., and Harbicht, S., 1997, Baseline studies in the Slave River, NWT, 19901994 Part III. MFO enzyme activity in fish: The Science of the Total Environment, v. 197, p. 87-109.

Wobeser, G.A., Nielson, N.O., and Scheifer, B., 1976, Mercury in mink. II. Experimental methyl mercury intoxication: Canadian Journal of Comparative Medicine, v. 40, p. 34-45. 
Wolfe, M.F., Schwartzbach, S., and Sulaiman, R.A., 1998, Effects of mercury on wildlife: a comprehensive review: Environmental Toxicology and Chemistry, v. 17, no. 2, p. 146-160.

Wolfe, R.J., 2000, Subsistence in Alaska: a year 2000 update: Division of Subsistence, Alaska Department of Fish and Game, Juneau, Alaska, 4 p.

Wolke, R.E., 1992, Piscine macrophage aggregates: a review: Annual Review of Fish Diseases, v. 2, p. 91-108.

Wolke, R.E., Murchelano, R.A., Dickstein, C.D., and George, C.J., 1985, Preliminary evaluation of the use of macrophage aggregates (MA) as fish health monitors: Bulletin of Environmental Contamination and Toxicology, v. 35, p. 222-227.

Wren, C.D., Hunter, D.B., Leatherland, J.F., and Stokes, P.M., 1987, The effects of polychlorinated biphenyls and methylmercury, singly and in combination, on mink. I: uptake and toxic responses: Archives of Environmental Contamination and Toxicology, v. 16, p. 441-447.

Yeardley, R.B., Jr., Lazorchak, J.M., and Paulsen, S.G., 1998, Elemental fish tissue contamination in northeastern U.S. lakes: evaluation of an approach to regional assessment: Environmental Toxicology and Chemistry, v. 17, p. 18751884.

Yukon River Inter-Tribal Watershed Council (YRITWC), 2002, Yukon River Unified Watershed Assessment: Alaska Region Office, Anchorage, Alaska, 44 p. 


\section{Appendix 1}


Appendix 1. Nominal Method Detection Limits (MDL) and results of quality assurance (QA) for organochlorine chemicals (ng/g ww) analyzed in whole body fish composites collected in the Yukon River Basin in 2002.

\begin{tabular}{|c|c|c|c|c|c|c|}
\hline \multirow{2}{*}{ Analyte } & \multicolumn{5}{|c|}{ Fortified Spike Percent Recoveries } & \multirow{2}{*}{$\frac{\mathrm{MDL}}{\mathrm{ng} / \mathrm{g} \mathrm{ww}}$} \\
\hline & $\# 1$ & \#2 & \#3 & \#4 & Mean & \\
\hline Pentachlorobenzene & 106 & 95 & 90 & 93 & 96 & 0.1 \\
\hline Hexachlorobenzene & 96 & 99 & 97 & 99 & 98 & 2.1 \\
\hline Pentachloroanisole & 48 & 118 & 118 & 114 & 100 & 0.2 \\
\hline Alpha-BHC & 81 & 85 & 80 & 87 & 83 & 0.2 \\
\hline Beta-BHC & 52 & 64 & 45 & 57 & 54 & 0.2 \\
\hline Lindane & 54 & 86 & 69 & 78 & 72 & 0.4 \\
\hline Delta-BHC & 81 & 78 & 47 & 72 & 70 & 0.1 \\
\hline Heptachlor & 92 & 64 & 68 & 39 & 65 & 0.2 \\
\hline Heptachlor epoxide & 70 & 73 & 70 & 78 & 73 & 0.2 \\
\hline Aldrin & 85 & 97 & 81 & 100 & 91 & 0.3 \\
\hline Dacthal & 26 & 96 & 81 & 99 & 75 & 0.3 \\
\hline Dieldrin & 108 & 78 & 72 & 84 & 85 & 0.2 \\
\hline Endrin & 80 & 21 & 33 & 59 & 48 & 0.1 \\
\hline Oxychlordane & 100 & 98 & 106 & 112 & 104 & 0.1 \\
\hline cis-Chlordane & 91 & 87 & 78 & 85 & 85 & 0.2 \\
\hline trans-Chlordane & 101 & 85 & 84 & 86 & 89 & 0.3 \\
\hline cis-Nonachlor & 71 & 81 & 79 & 87 & 79 & 0.1 \\
\hline trans-Nonachlor & 74 & 99 & 87 & 93 & 88 & 0.2 \\
\hline$o, p^{\prime}-\mathrm{DDE}$ & 83 & 74 & 75 & 79 & 78 & 0.2 \\
\hline$o, p^{\prime}$-DDD & 79 & 92 & 66 & 84 & 80 & 0.7 \\
\hline$o, p^{\prime}-\mathrm{DDT}$ & 89 & 94 & 79 & 94 & 89 & 0.1 \\
\hline$p, p^{\prime}-\mathrm{DDE}$ & 125 & 80 & 80 & 81 & 91 & 0.4 \\
\hline$p, p^{\prime}-\mathrm{DDD}$ & 77 & 89 & 90 & 95 & 88 & 0.4 \\
\hline$p, p^{\prime}$-DDT & 75 & 129 & 125 & 137 & 117 & 1.4 \\
\hline Endosulfan I & 106 & 89 & 77 & 96 & 92 & 0.3 \\
\hline Endosulfan II & 123 & 87 & 63 & 86 & 90 & 0.2 \\
\hline Endosulfate & 95 & 96 & 104 & 99 & 99 & 0.8 \\
\hline Methoxychlor & 94 & 130 & 153 & 131 & 127 & 1.7 \\
\hline Mirex & 90 & 101 & 81 & 100 & 93 & 0.0 \\
\hline Total PCBs & 94 & 96 & ND & 86 & 92 & 20 \\
\hline Total Toxaphene & 90 & 95 & 73 & 86 & 86 & 11 \\
\hline
\end{tabular}


Appendix 2 
Appendix 2. Histological observations in northern pike, longnose sucker, and burbot collected in the Yukon River Basin in 2002. Total number of individual tissues examined (n), percentage with no significant lesions and percentages with selected lesions are presented for each station.

\begin{tabular}{|c|c|c|c|c|c|c|c|c|c|c|}
\hline \multirow{2}{*}{ Species, Organ, and Lesion } & \multicolumn{10}{|c|}{ Station } \\
\hline & 301 & 302 & 303 & 304 & 305 & 306 & 307 & 308 & 309 & 310 \\
\hline \multicolumn{11}{|l|}{ Northern Pike } \\
\hline Liver, $n$ & 6 & 20 & 22 & 9 & 3 & 20 & 20 & 20 & 21 & 17 \\
\hline No significant lesions & 83 & 65 & 36 & 44 & 100 & 45 & 65 & 65 & 29 & 53 \\
\hline Biliary myxosporidians & 17 & 0 & 0 & 22 & 0 & 0 & 20 & 0 & 0 & 47 \\
\hline Ichthyophonus & 0 & 0 & 0 & 0 & 0 & 0 & 5 & 0 & 0 & 0 \\
\hline Nematodes & 0 & 5 & 0 & 0 & 0 & 0 & 0 & 5 & 0 & 0 \\
\hline Lymphocyte infiltrates & 0 & 30 & 64 & 33 & 0 & 50 & 10 & 35 & 71 & 0 \\
\hline Altered foci & 0 & 0 & 0 & 0 & 0 & 0 & 0 & 0 & 5 & 0 \\
\hline Fatty change & 33 & 0 & 18 & 0 & 0 & 20 & 0 & 10 & 0 & 0 \\
\hline Gill, $n$ & 6 & 18 & 22 & 7 & 1 & 19 & 19 & 20 & 21 & 17 \\
\hline No significant lesions & 17 & 22 & 73 & 43 & 0 & 42 & 16 & 20 & 33 & 46 \\
\hline Trichodinid ciliates & 83 & 0 & 9 & 43 & 100 & 37 & 68 & 55 & 5 & 6 \\
\hline Monogenetic trematodes & 17 & 78 & 5 & 14 & 0 & 0 & 32 & 30 & 24 & 27 \\
\hline Myxosporidians & 0 & 0 & 0 & 0 & 0 & 0 & 0 & 0 & 0 & 9 \\
\hline Epithelial hyperplasia & 17 & 33 & 9 & 0 & 0 & 5 & 6 & 20 & 38 & 6 \\
\hline Anterior kidney, $n$ & 6 & 19 & 22 & 9 & 3 & 20 & 18 & 20 & 20 & 13 \\
\hline No significant lesions & 100 & 100 & 100 & 100 & 100 & 100 & 94 & 100 & 100 & 100 \\
\hline Ichthyophonus & 0 & 0 & 0 & 0 & 0 & 0 & 6 & 0 & 0 & 0 \\
\hline Posterior kidney, $n$ & 6 & 20 & 22 & 9 & 3 & 20 & 20 & 20 & 21 & 17 \\
\hline No significant lesions & 0 & 30 & 27 & 11 & 67 & 5 & 10 & 25 & 62 & 0 \\
\hline Myxosporidians & 83 & 5 & 27 & 78 & 33 & 45 & 85 & 20 & 5 & 100 \\
\hline Ichthyophonus & 0 & 0 & 0 & 0 & 0 & 0 & 5 & 0 & 0 & 0 \\
\hline Glomerular microsporidian & 0 & 5 & 0 & 0 & 0 & 0 & 0 & 0 & 0 & 0 \\
\hline Developing nephrons & 33 & 70 & 64 & 22 & 0 & 90 & 25 & 70 & 33 & 6 \\
\hline Nephrocalcinosis & 33 & 0 & 0 & 0 & 0 & 20 & 0 & 0 & 0 & 6 \\
\hline Spleen, $n$ & 6 & 20 & 22 & 9 & 3 & 20 & 20 & 20 & 20 & 17 \\
\hline No significant lesions & 83 & 100 & 100 & 100 & 100 & 100 & 100 & 90 & 100 & 100 \\
\hline Lymphoid depletion & 17 & 0 & 0 & 0 & 0 & 0 & 0 & 10 & 0 & 0 \\
\hline \multicolumn{11}{|l|}{ Longnose sucker } \\
\hline Liver, $n$ & 12 & -- & -- & 2 & 21 & & 3 & 8 & -- & -- \\
\hline No significant lesions & 33 & -- & -- & 0 & 38 & & 33 & 13 & -- & -- \\
\hline Sanguinicolid trematode & 50 & -- & -- & 100 & 52 & & 67 & 88 & -- & -- \\
\hline Granulomas & 0 & -- & -- & 0 & 5 & & 0 & 0 & -- & -- \\
\hline Fatty change & 17 & -- & -- & 0 & 0 & & 0 & 0 & -- & -- \\
\hline Bile duct hyperplasia & 0 & -- & -- & 0 & 0 & & 33 & 0 & -- & -- \\
\hline Gill, $n$ & 12 & -- & -- & 1 & 20 & & 3 & 8 & -- & -- \\
\hline No significant lesions & 25 & -- & -- & 0 & 20 & & 33 & 0 & -- & -- \\
\hline Trichodinid ciliates & 0 & -- & -- & 0 & 5 & & 0 & 0 & -- & -- \\
\hline Chilodonella-like ciliate & 0 & -- & -- & 0 & 0 & & 0 & 63 & -- & -- \\
\hline Epitheliocystis-like organism & 8 & -- & -- & 0 & 0 & & 0 & 13 & -- & -- \\
\hline Sanguinicolid trematode & 25 & -- & -- & 0 & 25 & & 0 & 50 & -- & -- \\
\hline Myxosporidians & 25 & -- & -- & 100 & 70 & & 33 & 50 & -- & -- \\
\hline Epithelial hyperplasia & 42 & -- & -- & 0 & 35 & & 33 & 25 & -- & -- \\
\hline Anterior kidney, $n$ & 12 & -- & -- & 2 & 21 & & 3 & 8 & -- & -- \\
\hline No significant lesions & 100 & -- & -- & 100 & 100 & & 100 & 100 & -- & -- \\
\hline Posterior kidney, $n$ & 12 & -- & -- & 2 & 21 & -- & 3 & 8 & -- & -- \\
\hline No significant lesions & 25 & -- & -- & 0 & 38 & -- & 67 & 38 & -- & -- \\
\hline Myxosporidians & 8 & -- & -- & 0 & 5 & -- & 0 & 0 & -- & -- \\
\hline Sanguinicolid trematodes & 67 & -- & -- & 50 & 57 & -- & 0 & 25 & -- & -- \\
\hline Developing nephrons & 0 & -- & -- & 0 & 0 & -- & 33 & 25 & -- & -- \\
\hline Nephrocalcinosis & 17 & -- & -- & 0 & 10 & -- & 0 & 0 & -- & -- \\
\hline Hyaline droplets & 42 & -- & -- & 100 & 10 & -- & 0 & 13 & -- & -- \\
\hline Spleen, $n$ & 12 & -- & -- & 2 & 21 & -- & 3 & 8 & -- & -- \\
\hline No significant lesions & 100 & -- & -- & 100 & 86 & -- & 100 & 100 & -- & -- \\
\hline Sanguinicolid trematodes & 0 & -- & -- & 0 & 14 & -- & 0 & 0 & -- & -- \\
\hline
\end{tabular}


Appendix 2. Histological observations in northern pike, longnose sucker, and burbot collected in the Yukon River Basin in 2002. Total number of individual tissues examined ( $n)$, percentage with no significant lesions and percentages with selected lesions are presented for each station.-Continued

\begin{tabular}{|c|c|c|c|c|c|c|c|c|c|c|}
\hline \multirow{2}{*}{ Species, Organ, and Lesion } & \multicolumn{10}{|c|}{ Station } \\
\hline & 301 & 302 & 303 & 304 & 305 & 306 & 307 & 308 & 309 & 310 \\
\hline \multicolumn{11}{|l|}{ Burbot } \\
\hline Liver, $n$ & -- & -- & -- & -- & 12 & -- & -- & -- & -- & 1 \\
\hline No significant lesions & -- & -- & -- & -- & 42 & -- & -- & -- & -- & 0 \\
\hline Nematodes & -- & -- & -- & -- & 8 & -- & -- & -- & -- & 0 \\
\hline Granulomas & -- & -- & -- & -- & 58 & -- & -- & -- & -- & 100 \\
\hline Gill, $n$ & -- & -- & -- & -- & 5 & -- & -- & -- & -- & 1 \\
\hline Trichodinid ciliates & -- & -- & -- & -- & 60 & -- & -- & -- & -- & 100 \\
\hline Anterior kidney, $n$ & -- & -- & -- & -- & 9 & -- & -- & -- & -- & 0 \\
\hline No significant lesions & -- & -- & -- & -- & 89 & -- & -- & -- & -- & -- \\
\hline Granulomas & -- & -- & -- & -- & 11 & -- & -- & -- & -- & -- \\
\hline Posterior kidney, $n$ & -- & -- & -- & -- & 6 & -- & -- & -- & -- & 0 \\
\hline No significant lesions & -- & -- & -- & -- & 17 & -- & -- & -- & -- & -- \\
\hline Granulomas & -- & -- & -- & -- & 17 & -- & -- & -- & -- & -- \\
\hline Developing nephrons & -- & -- & -- & -- & 33 & -- & -- & -- & -- & -- \\
\hline Myxosporidians & -- & -- & -- & -- & 67 & -- & -- & -- & -- & -- \\
\hline Spleen, $n$ & -- & -- & -- & -- & 12 & -- & -- & -- & -- & 1 \\
\hline No significant lesions & -- & -- & -- & -- & 75 & -- & -- & -- & -- & 0 \\
\hline Granulomas & -- & -- & -- & -- & 25 & -- & -- & -- & -- & 100 \\
\hline
\end{tabular}


